FACULDADE DE SAÚDE PÚBLICA

Departamento de Saúde Ambiental

\title{
Plantas medicinais da Mata Atlântica (Vale do Ribeira - SP): extrativismo e sustentabilidade
}

\section{GEMIMA CIRILO CABRAL BORN}

Tese apresentada como parte dos requisitos para obtenção do título de Doutor em Saúde Pública (Ambiental) junto ao Departamento de Saúde Ambiental da Faculdade de Saúde Pública da Universidade de São Paulo.

\section{Orientadora:}

Prof $^{\mathfrak{a}}$. Dra. Helena Apparecida dos Santos

Lima Pereira

São Paulo, janeiro de 2000. 
À mamãe, Maria Odete Cabral, e ao papai, Miguel Cirilo Cabral, pelos princípios éticos e valores morais, pela bravura, coragem, sabedoria e alegria que me ensinaram.

Ao meu grande amor, Rubens Harry Born, que, há muito tempo, me encoraja, orienta e me dá o principal da vida: muito amor. 
Ao Sr. Sátiro Tavares da Silva, líder político e espiritual da Estação ecológica de Juréia-Itatins (in memoriam), um ser humano de grande sabedoria e que sempre estava disposto a ajudar as pessoas. 


\section{Agradecimentos}

Ao Universo, pela grande oportunidade que me proporcionou permitindo que eu realizasse essa tese, que tenta mesclar conhecimento e sabedoria adquiridos.

À minha orientadora Prof ${ }^{\mathrm{a}}$. Dra. Helena Apparecida dos Santos Lima Pereira pelas orientações sábias; por me deixar sonhar e tentar realizar meus sonhos.

Ao CNPq - Conselho Nacional de Desenvolvimento Científico e Tecnológico-, pela bolsa concedida no período de 1994 à 1998.

Ao Vitae Civilis - Instituto para o Desenvolvimento e Paz -, pela grande oportunidade que tem me dado e na qual tenho crescido profissional e pessoalmente.

À Rainforest Alliance (New York), na pessoa da minha querida e meiga Sarah Laird, pela bolsa do Periwinkle Project, que ganhei, em um processo sério de seleção. Essa bolsa possibilitou o desenvolvimento do projeto Juréia-Itatins, que foi a base do trabalho aqui apresentado e alavancou todos os trabalhos sobre plantas medicinais e desenvolvimento de comunidades rurais realizados no e em conjunto com o Vitae Civilis.

Aos patrocinadores do Vitae Civilis, pelo apoio financeiro dado: Rainforest Alliance (1991 - 1994); Rainforest Action Network (1994, 1995 e 1997); Programa das Nações Unidas para o Desenvolvimento (PNUD-NY, 1994-1995); Both Ends (1995); Fundo Nacional do Meio Ambiente (Convênio Vitae Civilis/MMA-FNMA no 102/96); Comitê Holandês para a IUCN (1997 e 1998), Fundação Francisco (1993, 1995, 1996, 1997); Novib (1997); Fundação W. K. Kellogg (1998); WWF (Congressos e cursos de Etnobotânica, manejo sustentável etc.- Índia e México) e Fundação Ford (1999-2000). Todas as verbas recebidas apoiaram o desenvolvimento dos projetos Juréia-Itatins, Intercâmbio com o Vietnã, Propriedade Intelectual de comunidades tradicionais, Da mata à casa, entre outros do Vitae Civilis e, conseqüentemente, contribuíram também para a realização desta tese.

Ao Sr. Sátiro Tavares da Silva, líder político e espiritual das comunidades da Estação ecológica de Juréia-Itatins, pelos grandes momentos que passamos juntos na Juréia-Itatins, quando tentei aprender e séntir um pouco de sua sabedoria.

Às comunidades da Cachoeira do Guilherme, Aguapeú, Grajaúna, Praia do Una, Rio Verde, Rio Comprido, Rio das Pedras, Serra e à do Despraiado da Estação ecológica Juréia-Itatins, pelo grande apoio dado ao projeto Juréia-Itatins, no período de 
1989 a 1995; pelo desejo de ter melhores condições de vida, que os incentivou à realização do primeiro levantamento de dados do mercado de plantas medicinais da região metropolitana do Estado de São Paulo, realizado em 1992.

A Paula e Pradel Martins Tavares, Dinei e Joaquim, filho do Sr. Sátiro (Cachoeira do Guilherme); D. Romana e Sr. Bianor (Aguapeú); Oscar e Jairo (Despraiado); Irene e Arenildo (Rio das Pedras); Nadir e Totó (Rio Comprido); Sr. Onérsio e D. Nanci (Grajaúna); Sr. Malvino e Dalva (Rio Verde); D. Marlene e Sr. Zé Maria (Serra) e a todos aqueles que alojaram, em suas casas, a equipe do projeto Juréia-Itatins.

A Dauro Prado e a Orlando Tavares Martins, pela grande disposição, pelas orientações e pelos ensinamentos fornecidos durante o desenvolvimento do projeto Juréia-Itatins.

Ao Sr. Carlos Alberto Novi, uma das lideranças da região do Vale do Ribeira, pelo entusiasmo e pela crença de que é possível conservar a Mata Atlântica dessa região e, ao mesmo tempo, proporcionar condições para que famílias rurais e urbanas tenham melhores condições de vida.

Aos extratores e produtores de plantas medicinais, que nos ensinaram seus conhecimentos e sua arte em trabalhar com as plantas medicinais da Mata Atlântica.

A todos os entrevistados e as suas respectivas instituições, pelas informações e percepções fornecidas, contribuindo para a realização desta tese.

Aos seguintes simpatizantes do Vitae Civilis e dos projetos que coordenei: José Roberto Beto Borges (Shamam), Paul Wolvekamp e Tamara Mohs (Both Ends), Humberto Mafra (Fundação Francisco), Jennie Wood Sheldon (UNDP), Gary Martin e Anthony B. Cunningham (Plant and People), Beth Monosowski (Banco Mundial), Helena Albuquerque (Rainforest Alliance), Nguyen Thi Quy (University of Hanoi).

À Dra. Lúcia Rossi e a todos os pesquisadores do Instituto de Botânica do Estado de São Paulo, pela identificação botânica das plantas coletadas.

À Associação Brasileira para Desenvolvimento de Lideranças (ABDL) e ao Programa "Leadership for Environment and Development", Programa Lead - Brasil, pela bolsa concedida, no período 1996 a 1998, que muito contribuiu para minha formação.

À Igreja Batista de Arcoverde e ao Colégio Onze de Setembro, na pessoa do Pastor Israel Guerra e de sua esposa, Prof ${ }^{\mathrm{a}}$. Mestre Edilazir Guerra, pelo apoio dado ao 
meu pai e, conseqüentemente, a mim.

À minha amiga Joenita Bezerra, ex-presidente do Sindicato dos Comerciários de Arcoverde, pelas oportunidades a mim concedidas.

À minha amiga e irmã, Geralda Cabral Vitória Sena, pela grande ajuda moral e financeira que me deu durante meus anos de estudante em Pernambuco; agradeço também a seu esposo, Luiz Vitória Sena (in memoriam).

Ao meu amigo e irmão, Gênison C. Cabral, pelo grande apoio moral e prático.

À minha amiga Dra. Lilian Willadino e ao meu amigo e professor, Prof. Mestre Tarcísio Pereira (in memoram) pelos ensinamentos que me proporcionaram.

A todos que trabalham e que trabalharam no Vitae Civilis e de alguma forma auxiliaram nos trabalhos com plantas medicinais.

À Daniela Aparecida Dias, funcionária do Vitae Civilis, pelo grande apoio amizade.

Aos companheiros Antônio Carlos Alves de Oliveira (o grande Tonhão e presidente do Vitae Civilis), Neide Yumie Takaoka e Francisco L. Rodrigues, conselheiros do Instituto Vitae Civilis, pelos momentos juntos e pelas orientações políticas recebidas.

À Sra. Luzia, pelos conselhos e pelas orientações espirituais.

À D. Carina, pelo carinho e pelos trabalhos realizados.

À Maria Rita da Luz, pelo carinho com que cuidou de minha casa;

À minha terapeuta, Dra. Cristina Freire, por coordenar sabiamente minhas incertezas/certezas, tristezas/alegrias, ..., no meu longo caminho em busca do equilíbrio.

Às minhas colegas do grupo de terapia e à terapeuta, Dra. Marta Dias Murano, pelo desprendimento de falar tudo o que sentiam e viam quanto ao meu comportamento e, assim, ajudarem-me a trabalhar vários pontos importantes, o que me possibilitou escrever esta tese.

Às minhas amigas, Daniela Chrisma Danielides, Ana Lúcia Pereira Horn e Eliana Rodrigues, pela grande amizade que me proporcionaram também energia para a elaboração desta tese.

À minha companheira de trabalho; Eliana Rodrigues, pela leitura e sugestões dadas.

\section{Muito obrigada!}




\section{Resumo}

Esta tese compreende a análise e verificação da extração e comercialização de plantas medicinais que ocorrem naturalmente em áreas de Mata Atlântica, na perspectiva de que tais atividades compõem instrumentos e estratégia de desenvolvimento sustentável na região do Vale do Rio Ribeira de Iguape, no sul do Estado de São Paulo. Esta região detém a maior área remanescente contínua de Mata Atlântica e é habitada por comunidades, que dependem do uso de recursos naturais renováveis para a subsistência. Entre os recursos naturais renováveis explorados, destacam-se as plantas medicinais que já são extraídas e comercializadas na região.

Foi realizado um levantamento etnobotânico junto a uma amostra representativa dos extratores e produtores de plantas medicinais do Vale do Ribeira, e através dele foram resgatadas, documentadas e analisadas informações pormenorizadas sobre as plantas e sobre os métodos tradicionais, utilizados para identificar, extrair, transportar, beneficiar, armazenar e comercializar plantas medicinais. Foram observadas, também, as percepções e opiniões dos extratores e produtores entrevistados a respeito das relações entre esse grupo e os órgãos governamentais responsáveis pela fiscalização e controle dos recursos, bem como no que respeita à associação que os representam (Aepam - Associação de Extratores e Produtores de Plantas Aromáticas e Medicinais do Vale do Ribeira), especialmente no que concerne à conservação da biodiversidade e das plantas medicinais. Foram realizados levantamentos bibliográficos para saber a origem e a existência de estudos sobre ação farmacológica e propriedade fitoquímica das plantas identificadas até o nível de espécie.

A análise e discussão, nessa tese, considerou vários temas e questões de referência para se lidar com a sustentabilidade da extração de plantas medicinais da Mata Atlântica. Entre tais temas e questões, destacam-se a valorização e importância do conhecimento tradicional; a etnobotânica e etnociências como instrumentos para o fortalecimento e desenvolvimento de comunidades rurais e tradicionais; aspectos do mercado local, nacional e internacional; inventário florestal contínuo; identificação botânica; conceitos de desenvolvimento sustentável; legislação sobre conservação ambiental e fitoterápicos. Especial consideração foi dada aos princípios, consagrados pela Convenção de Diversidade Biológica, que tratam do acesso ao conhecimento 
tradicional e à repartição de benefícios que advém do uso desse conhecimento e dos recursos biológicos.

O estudo demonstrou que alguns dos entrevistados possuíam técnicas bem trabalhadas para realizar a identificação da área e da planta a serem submetidas ao manejo tradicional, bem como sobre a extração do material vegetal e o processamento (a secagem, a trituração e o controle de qualidade) do produto final. Por outro lado, o estudo realizado aponta também que a grande maioria dos extratores não observa periodicidade de extração em relação à área e a planta, nem à quantidade do material extraído. $\mathrm{O}$ mercado é o fator determinante desses parâmetros e da atividade extrativa, que ainda está longe de atender padrões de práticas sustentáveis.

As evidencias e análises presentes nesse estudo apontam para uma dualidade no que se refere às plantas medicinais da Mata Atlântica na região do Vale do Ribeira. De um lado, a extração tem ainda importância marginal, do ponto de vista econômico (apesar que pode ser de relevância para algumas famílias e comunidades extrativistas), e é realizada em formas que estão longe de atender aos critérios de sustentabilidade. Por outro lado, há um rico conhecimento tradicional e ampla diversidade de espécies, ainda a serem reconhecidos e valorizados pela comunidade científica, por órgãos governamentais e outros atores. Há também crescente interesse e mobilização de diversos atores sociais para a difusão da importância das plantas medicinais, seja pela sua extração sustentável ou cultivo, permitindo inferir uma tendência de valorização de tal atividade como elemento inerente à uma estratégia sistêmica de desenvolvimento sustentável do Vale do Ribeira, incluindo-se a conservação da rica cultura e da diversidade biológica encontrada em regiões da Mata Atlântica.

O estudo aponta ainda informações e critérios que podem ser a base e ser expandidos para o uso de plantas medicinais, mesmo em outras regiões do país, e enfatiza a valorização dos conhecimentos tradicionais nos esforços de conservação da biodiversidade, gestão e promoção da saúde ambiental e da qualidade de vida das populações que vivem em áreas ambientalmente protegidas. 


\section{Summary}

This thesis deals with the analysis and observation of the extraction and commercialization of medicinal plants, naturally found in the Atlantic Rainforest. One of its premises is that sustainable extraction, commercialization and use of medicinal plants can be an important tool and strategic element in the quest of sustainable development in the Ribeira do Iguape River Basin, in the south of São Paulo State. That region presents the most and largest continuous remaining areas of Atlantic Rainforest, and it is inhabited by rural and traditional communities that depend on the use of the forest natural resources for their subsistence. Medicinal plants are some of the renewable resources that have been collected and trade in the region.

A ethnobotanical survey was done with a representative sample of the Vale do Ribeira's extractors and producers of medicinal plants. The study recorded data and knowledge on the medicinal plants as well as on the traditional methods have been used for harvesting, processing, stocking, transporting and trading medicinal plants. It has also been observed and recorded the perception, expectation and views of the studied sample extractors and producers as regard to their relationship with governmental agencies and their officials as well as with the Association that was founded to represent them (Aepam- Association of Extractors and Producers of Medicinal and Aromatic Plants of Vale do Ribeira), specially on the issues and challenges posed by the need for biodiversity conservation. Complementary bibliographic survey was conducted in order to check the existence and origin of scientific studies on the pharmacological action and phytochemical property of the medicinal species.

The analysis and discussion has considered several issues and concepts as reference for the evaluation of the sustainability of extraction of medicinal plants in that region of Atlantic Forest, such as: the value and importance of traditional knowledge; ethnobotany and ethnosciences as tools for the empowerment and development of traditional and rural communities; local, national and international market features; continued forest inventory; botanical taxonomic studies; legislation on environment conservation and phytotherapy. Special attention has been given to the principles stated by the Convention of Biological Diversity regarding access to traditional knowledge and sharing the benefits that arise from the use of the biological and knowledge 
resources.

The study shows that some of the interviewees possess detailed techniques to identify the area and the plants to be traditionally managed, as well as to the processing of the plants (drying, grinding, etc.) . On the other hand, it shows the majority of the extractors do not observe quantitative limits nor seasonal conditions, both as regard to the exploited area or the plants species. The market is the driving force of the extraction parameters, which are far from sustainable practices .

The analysis and evidences show a duality of the medicinal plants extraction and conservation in the region: on one side, the activity is small, marginal from the economic regional point of view (in spite of the fact that for some families and communities, it can be relevant) and is being conducted in a non-sustainable pattern. On the other hand, there is a rich traditional knowledge on medicinal plants and a wide diversity of species, yet to be recognized and valued by the scientific community, governmental organs, non governmental organizations and other stakeholders. There is also a growing movement and interest to support and to enhance the sustainable extraction and or cultivation, the commercialization and use of medicinal plants as part of a systemic strategy for the sustainable development of the Vale do Ribeira and for the conservation of the rich culture and biological diversity found in that region of the Atlantic Rainforest.

The thesis shows criteria and information that may form the basis and can be enhanced for the sustainable use of medicinal plants, even from other regions, and stress the importance to consider and to value the traditional knowledge for the improvement of biodiversity conservation, health and quality of life of inhabitants of environmental protected areas. 


\section{Índice}

Apresentação, 13

1. INTRODUÇĀO, 20

\section{O CONTEXTO E A GÊNESE DA TESE, 29}

2.1. O Vitae Civilis, 29

2.2. A gênese da Aepam, 29

2.3. O projeto Da mata à casa, 29

\section{MARCOS CONCEITUAIS E CONTEXTUAIS, 29}

\subsection{Sustentabilidade do desenvolvimento, 29}

3.2. A pesquisa etnobotânica, 29

\subsection{Plantas medicinais, 29}

3.3.1. Manejo sustentável de plantas medicinais da Mata Atlântica, 29

3.3.2. Aspectos do mercado de plantas medicinais, 29

3.3.3. Questões legais, 29

3.3.3.1. Acesso, exploração e comercialização de plantas medicinais da Mata Atlântica, 29

3.3.3.2. Uso de fitoterápicos, 29

3.3.3.3. Da repartição dos beneficios provenientes do uso do conhecimento tradicional, 29

4. CARACTERIZAÇÃo da ÁREA, 29

\subsection{A Mata Atlântica, 29}

4.1.1. Aspectos físicos e diversidade biológica, genética e cultural, 29

4.1.2. Aspectos da delimitação e da proteção, 29

4.1.3. Distribuição original e atual, 29

4.2. A região do Vale do Ribeira, 29

4.2.1. Delimitação e aspectos físicos da região do Vale do Ribeira, 29

4.2.2. Aspectos históricos, sociais, econômicos e culturais, 29

4.2.3. Aspectos políticos e legais da conservação, 29

\section{EXTRATIVISMO E COMERCIALIZAÇÃo DE PLANTAS MEDICINAIS NO VALE DO} RIBEIRA, 29

\subsection{O levantamento etnobotânico, 29}

5.1.1. A área e a amostragem do universo da pesquisa, 29

5.1.2. Instrumentos e estratégias dos levantamentos de campo, 29

5.1.3. Coleta de material vegetal e identificação botânica, 29

5.1.4. Instrumentos e estratégias dos levantamentos bibliográficos, 29

5.1.5. Organização, análise e interpretação dos dados, 29

\subsection{Diagnóstico socioeconômico-político da amostra, 125}

5.2.1. A amostra e a distribuição dos extratores e produtores de plantas medicinais, 125

5.2.2. Caracterização da amostra, 127

5.2.3. Aspectos dos guias principais, 128 
5.2.4. Percepçð̃es dos extratores e produtores sobre as relaçð̃es entre os atores envolvidos e a conservação das plantas medicinais, 131

5.3. O saber etnobotânico da amostra de extratores e produtores de plantas medicinais, 138

5.3.1. As plantas manejadas, 138

5.3.2. As áreas do manejo tradicional, 152

5.3.3. O manejo tradicional, 163

5.3.4. O beneficiamento e a comercialização, 172

5.3.5. Correlações entre dados, 190

6. DESAFIOS PARA O USO SUSTENTÁVEL DE PLANTAS MEDICINAIS, 192

6.1. Da sustentabilidade da extração e comercialização de plantas medicinais da Mata Atlântica, na região do Vale do Ribeira, 197

6.2. Recomendações e conclusões finais, 201

7. REFERÊNCIAS BIBLIOGRÁFICAS, 205

Lista de abreviaturas e símbolos, 219

Lista de figuras e esquemas, 220

Lista de fotos, 221

Lista de gráficos, 222

Lista de tabelas, 223

Lista de anexos, 226 


\section{Apresentação}

Esta tese trata de extrativismo e comercialização de plantas medicinais da Mata Atlântica realizados na região do Vale do Ribeira. Conseqüentemente, ela trata também espaço do uso das plantas medicinais, e da sabedoria popular a esse respeito, que ocorre espontaneamente em áreas de mata, ruderal (incluindo os jardins, quintal) ou cultivada, em escala comercial ou doméstica.

Essa tese é o resultado da associação de dois mundos diferentes $\mathrm{e}$ complementares pelos quais tenho transitado. Um deles é intelectualizado e o outro é empírico e baseado na sabedoria popular.

Minha entrada nesse mundo intelectualizado teve início na Universidade Federal Rural de Pernambuco, com o curso Bacharel em Ciências Biológicas. Esse curso foi aprimorado na Universidade de São Paulo, no Instituto de Biociências e na Faculdade de Saúde Pública.

Após quatro anos de estudos e adaptação intensos, defendi a dissertação intitulada Morfogênese in vitro de Kalanchoe blossfeldiana, com orientação do Prof. Dr. Walter Handro e co-orientação da Prof ${ }^{\mathrm{a}}$. Dra. Eny Floh, ambos professores do Departamento de Botânica desse Instituto. Foi assim que obtive o título de Mestre em Botânica.

O mundo prático dotado de sabedoria popular me foi apresentado bem antes disso, por minha mãe e meu pai, ambos nordestinos que nasceram e se criaram em sítios localizados em áreas rurais do agreste pernambucano.

Falarei, portanto, desses dois mundos, o intelectual e o empírico, já que considero impossível disvincular deles minha trajetória de vida, que me vem proporcionando vários resultados e aprendizados. Um deles é a tese, ora apresentada. Tentarei apresentar esses dois mundos no espaço e no tempo em que eles foram se tornando parte de minha vida.

O mundo sábio, que me foi apresentado por meus pais começou no sítio Pacas, localizado no município de Cortês, na zoña da mata de Pernambuco. Lá, encontramos ainda pouquíssimos fragmentos da Mata Atlântica, que, quando ocorrem, são muito pequenos.

Foi com a ajuda de uma parteira que recebi os primeiros remédios. Todos eram à 
base de ervas medicinais. Era um lugar distante e, portanto, ficava muito dificil ir até à cidade para consultar um médico. "Médico é coisa de gente com dinheiro", explicava minha mãe quando todas as vezes contava com muita saudade e tristeza que seu filho mais velho, portanto meu irmão mais velho, morrera de uma doença não conhecida por ela na época. Quando ela foi morar na cidade, descobriu que seu filho tinha morrido de desidratação. Poderiam dizer que esta morte foi causada pela falta de um remédio caseiro muito simples, mas não foi só isso, foi muito mais. Foi a falta de informação e de orientação que fizeram meus pais perderem o primogênito. Outras histórias são contadas por meus pais, várias são alegres, mas algumas, tristes.

Meu pai e minha mãe perceberam logo cedo que não gostariam de viver sempre em um sítio porque eles queriam que todos os seus filhos tivessem a oportunidade de "estudar para ser alguém na vida". Eles sabiam o quanto isso era importante, pois nenhum dos dois freqüentou a escola. Aprenderam a ler, escrever e fazer contas sozinhos.

Com esse pensamento e com muita vontade de vencer, meu pai conseguiu um emprego na Rede Ferroviária Federal. A partir daí começamos a andar por várias cidades dos Estados de Pernambuco e de Alagoas. Mas foi na cidade de Arcoverde, conhecida como a porta de entrada da Caatinga pernambucana, que vivemos a maior parte do tempo. Lá vivi a minha infância e adolescência.

Foi em Arcoverde que minha mãe me ensinou a identificar e a usar várias plantas medicinais. Algumas delas só apareciam após um dos rituais da natureza, o mais bonito que já conheci: uma trovoada na Caatinga. Embaixo daquele sol escaldante, tudo seco, sem folhas, apenas algumas plantas verdes, como umbu e aveloz, o céu azul brilhante, com nuvens branco-acinzentadas, a terra começava a cheirar e tudo começava a mudar de maneira crescente. Começava a gotejar e quando firmava, vinha a trovoada. Chuva forte que nos dava a água abençoada, recolhida em latas e em cisterna. Logo após a chuva, o visual começava a mudar. Tudo ficava verde, sementes germinando, plantas florindo, frutificando. Era uma verdadeira explosão de vida. Era lindo!

Essa beleza era somada com a sabedoria e o equilíbrio dos meus pais que souberam dar a seus filhos a base para a vida: valores como honestidade, respeito, viver com sabedoria e equilíbrio, lutar para concretizar os desejos, ter ética. De origem nordestina e rural, meus pais foram muito contundentes quando nos ensinaram seus valores. 
De religião Batista, Diácomo da Igreja Batista de Arcoverde e fornecendo serviços de pedreiro como voluntário, meu pai conseguiu que todos os seus filhos estudassem, gratuitamente, no colégio dessa Igreja, Colégio Onze de Setembro.

Quando saí dessa escola, fiz o vestibular e comecei o curso de Letras na Faculdade de Serra Talhada.

Em Arcoverde, comecei a trabalhar aos quatorze anos e, assim, a ajudar no orçamento doméstico. Comecei minha vida profissional em uma mercearia que virou um supermercado. Fui vendedora e caixa. Em seguida, fui auxiliar administrativo de uma maternidade e de uma fábrica de doces e, depois, administradora de uma empresa de compra e venda de carros usados.

Participava do Sindicato dos Comerciários de Arcoverde, o que me proporcionou a participação em leituras e análises críticas sobre aspectos sociais, políticos e econômicos, em plena ditadura militar. Proporcionou-me também, em 1975, meu primeiro vôo de Arcoverde para São Paulo, para fazer um curso.

Com a ajuda de amigos, consegui conhecer Recife. Fiquei encantada e comecei a ter um desejo: viver em Recife para estudar. Com a sabedoria adquirida de meus pais, consegui economizar dinheiro e prestar um concurso para participar do curso sobre Artes Práticas - Técnicas Comerciais, realizado na Universidade Federal de Pernambuco. Após seis meses de curso, formei-me e comecei a aguardar um chamado da Secretaria de Educação do Estado de Pernambuco para lecionar em uma de suas escolas. Enquanto aguardei, fiz o cursinho, mantendo-me com o dinheiro que tinha economizado. Estudei muito e passei no vestibular para o curso Bacharel em Ciências Biológicas da Universidade Federal Rural de Pernambuco (UFRPE).

Durante a estadia na UFRPE, consegui me manter financeiramente lecionando, recebendo ajuda da minha querida irmã e amiga, Geralda, e sendo monitora da disciplina Fisiologia Vegetal dessa universidade, após ter sido selecionada em um concurso. Fiz então pesquisas com uma bolsa de Iniciação Científica do Conselho Nacional de Desenvolvimento Científico e Tecnológico - CNPq.

Mesmo trabalhando muito, tive tempo de participar ativamente do Movimento Estudantil da UFRPE, no período de 1978 a 1982, e do Movimento Ambientalista.

Em 1981, encontrei meu grande amor, Rubens Harry Born, que hoje é também meu companheiro de trabalho. Foi após a participação em um movimento dos trabalhadores para comemorar o Dia do Trabalhador, que me encontrei com ele e outras 
pessoas para conversar sobre o Movimento Contra a Caça às Baleias. Naquela época eu já participava do Movimento Ambientalista, preocupando-me tanto com a conservação da biodiversidade quanto com a melhoria da qualidade de vida das populações, especialmente daquelas economicamente menos favorecidas.

Após quase um ano de separação de Rubens para concluir o curso de Biologia, fui morar em São Paulo, em 1982. Em São Paulo, comecei a tentar concretizar um de meus desejos: estudar na USP!

Fui ao Departamento de Botânica e solicitei estágio no Laboratório de Fisiologia Vegetal. O segundo professor a quem fiz essa solicitação, aceitou orientar-me e, com sua orientação, defendi minha dissertação de mestrado. Foi uma experiência excelente, tanto pelo lado do aprendizado botânico quanto pelo do aprendizado das diferenças entre os dois "Brasis" (Pernambuco e São Paulo). Foi também um aprendizado perceber claramente que a vida é como é, e não como gostaríamos que fosse.

Antes de defender a dissertação, fui lecionar Botânica Econômica no curso de Biologia da Universidade Mackenzie, por indicação da Dra. Lúcia Rossi, sistemata vegetal do Instituto de Botânica do Estado de São Paulo. No segundo semestre, quando estava lecionando nessa universidade, os alunos do terceiro ano de Biologia escolheram Botânica Econômica para fazer suas monografias de conclusão de curso. Naquela época, eu trabalhava com tecnologia de ponta, cultura de tecido vegetal, e a Universidade Mackenzie não tinha estrutura para realizar experimentos in vitro. Conversando com meus alunos, chegamos à conclusão de que poderiamos realizar um levantamento do conhecimento tradicional das parteiras da Aldeia de Carapicuíba (região metropolitana de São Paulo). Foi a partir daí que comecei a estudar plantas medicinais de maneira sistematizada. Participei de vários cursos, dentre os quais destaco o de Etnofarmacologia, promovido pela Fundação Brasileira de Plantas Medicinais.

Em 1989, como um dos resultados do trabalho realizado na Aldeia de Carapicuíba, fui convidada pela Secretaria do Meio Ambiente do Estado de São Paulo para realizar um levantamento etnofarmacológico junto ao curandeiro Sátiro Tavares da Silva, da Estação ecológica de Juréia-Itatins.

Antes de aceitar a proposta, conversei com os técnicos do governo responsáveis, na época, pela administração da estação ecológica sobre a abordagem que usaria para realizar tal levantamento. No levantamento etnofarmacológico estava incluso também o levantamento de elementos essenciais para se entender aspectos importantes das 
condições sociais, culturais, econômicas e políticas das comunidades da Juréia-Itatins. Propus que fosse ampliado o universo para as comunidades tradicionais da JuréiaItatins. Tais sugestões foram aceitas pelos técnicos e assim prestei uma consultoria a essa secretaria, desenvolvendo o projeto Levantamento etnofarmacológico e de aspectos socio-econômico-culturais das comunidades tradicionais da Cachoeira do Guilherme e do Rio Comprido.

Quando entrei em contato com o Sr. Sátiro, surpreendi-me com a lucidez de suas idéias e com a sabedoria de suas palavras. Ele demonstrou coerência, ética e consciência bastante clara do que é justo e do que não é. Sua linguagem era simples, mas suas idéias de igualdade e justiça, de respeito e amor ao próximo e à natureza eram bastante elaboradas e equilibradas. Durante o período em que trabalhamos juntos, pude perceber que ele sempre se preocupou em transmitir aos outros o conhecimento que possuía, visando a melhoria das condições de vida das pessoas e uma vivência harmoniosa com a natureza. Os membros da comunidade que possuíam maior contato com ele, geralmente parentes, acabaram sendo pessoas de algum destaque na comunidade. Pelo que pude perceber, isso aconteceu não por causa de qualquer imposição da parte do Sr. Sátiro, mas pelo equilíbrio que suas idéias transmitiram às pessoas que mais conviveram com ele. Foi para evidenciar isso que optei por citar o parentesco com o Sr. Sátiro de algumas das pessoas que serão citadas nesta tese.

Esse primeiro levantamento proporcionou a elaboração do projeto Juréia-Itatins, visando a conservação da Mata Atlântica e a melhoria da qualidade de vida da população que habitava a Estação ecológica de Juréia-Itatins (ver 2.1. O Vitae Civilis).

Ao término dessa consultoria, comecei a procurar recursos financeiros para continuar o trabalho iniciado com os moradores da Juréia-Itatins. Soube por meio de meu companheiro, Dr. Rubens Harry Born, a respeito de uma nota publicada pela Rainforest Alliance. A Rainforest Alliance é uma organização americana nãogovernamental, sem fins lucrativos e publicara nota solicitando propostas que visassem a conservação de florestas tropicais e o desenvolvimento de comunidades locais, tendo como mote o uso e a conservação de plantas medicinais. Candidatei-me à bolsa do Periwinkle Project desta ONG americana e fui a única selecionada entre 35 pesquisadores do Brasil e dos Estados Unidos da América. Recebi esta bolsa durante o período de 1991 a 1994, a qual possibilitou introduzir no Vitae Civilis, uma organização não-governamental sem fins lucrativos, o programa Bio-rural e os trabalhos sobre a 
conservação da Mata Atlântica e o desenvolvimento sustentável da região do Vale do Ribeira (ver 2.1. O Vitae Civilis), tendo como mote as plantas medicinais. Foi a partir dessa bolsa que vários estudantes e recém-formados que estagiaram e trabalharam sob minha orientação, no Vitae Civilis, tiveram oportunidade de treinamento e capacitação para o mercado de trabalho, principalmente na área ambiental.

Foi desse modo que desenvolvi o projeto Juréia-Itatins no âmbito do Vitae Civilis. Nessa mesma época, acumulei as aulas de Botânica Econômica na Universidade Mackenzie e a realização, coordenação e administração do referido projeto.

Em 1994, em conseqüência do grande acúmulo de trabalho e do comprometimento com as demandas socioambientais, decidi trabalhar somente no Vitae Civilis. Transferi, então, minhas aulas de Botânica Econômica na Universidade Mackenzie para uma componente da minha equipe do Vitae Civilis.

Há momentos em que as ONGs têm dificuldades de obter recursos para remunerar os profissionais que nela trabalham. Outro problema, fruto da realidade brasileira (que não costuma ocorrer na realidade americana ou na européia), é que a grande maioria dos estudantes ou profissionais, mesmo no início da carreira, precisa e exige ser remunerada. Assim, a transferência das minhas aulas para um membro da equipe do Vitae Civilis, naquela época, permitiu transpor certas dificuldades pois compensou os meses em que a ONG não obteve recursos para remunerar o trabalho por ela realizado.

Desde 1989, trabalho no Vitae Civilis, oportunidade que me tem proporcionado a orientação e a formação de profissionais; a gestão de recursos financeiros; a concepção e a realização de projetos bem-sucedidos e premiados (ver 2.1. O Vitae Civilis). Essa tese não é apenas um resultado da trajetória de minhas vidas profissional e particular, é também um dos resultados do trabalho que realizo hoje no Vitae Civilis (ver 2.3 - O projeto Da mata à casa).

Desejo que todos aqueles que nasceram e se criaram em área rural e também aqueles que tiveram experiência apenas na área urbana compreendam a essência desta tese. Ela retrata mais do que apenas a metodologia e a abordagem usadas, os resultados obtidos, as conclusões e as recomendações. Ela trata da complementaridade e da sinergia entre os dois mundos em que transitei em minha vida. Dois mundos que poderiam e deveriam ser compreendidos e articulados por todos, cientistas, ativistas socioambientais, empresários, lideranças, entre outros, que trabalham pela busca da 
sustentabilidade do desenvolvimento, ou seja, pela conservação ambiental, pela justiça social, pela promoção da saúde e da qualidade de vida, pela integridade da vida (de todos os seres vivos), que habitam o planeta Terra.

A autora. 


\section{INTRODUÇÃO}

O ambiente do nosso planeta tem sofrido grandes e crescentes degradações de origem antrópicas, especialmente ao longo das últimas décadas. São inúmeras as causas e os fatores associados aos processos de degradação, destacando-se a conjunção de características e processos econômicos das instituições políticas e sociais, assim como, a ampliação de abordagens culturais e da ciência que regulam, desconsideram ou tratam inadequadamente as dimensões e as esferas da vida pública e privada tanto dos seres humanos como do ambiente.

A dimensão do desenvolvimento humano que tem recebido maior importância é a econômica. As dimensões sociais, culturais, políticas, ecológicas, global, e até mesmo a econômica, não estão voltadas para a qualidade de vida dos seres humanos e, portanto, pouca importância dão à saúde, pública e ambiental. Desenvolvimento e progresso humano, nos últimos dois séculos, transformaram-se em sinônimos de crescimento quantitativo e acumulação.

As inter-relações das várias dimensões do desenvolvimento cultural e social das civilizações têm sido tratadas assimetricamente. As abordagens baseadas em modelos fragmentados e desarticulados não têm permitido alavancar políticas e medidas para a solução dos problemas criados pelo estilo vigente e hegemônico de desenvolvimento.

O relatório Nosso Futuro Comum, da Comissão Mundial sobre Meio Ambiente e Desenvolvimento, apresentou os paradoxos e contrastes resultantes da evolução da ciência, da economia e da política ocidental nesses últimos séculos. De um lado, o aprofundamento do conhecimento e das políticas especializadas produziram $o$ desenvolvimento tecnológico, a identificação de agentes etiológicos e o tratamento de muitas enfermidades; o aumento da produção e da produtividade agro-industrial; a construção de obras e infra-estrutura urbana; as comunicações e o transporte. Por outro lado, ampliaram-se, exponencialmente, as mazelas sociais e ambientais; a depredação de recursos naturais; a extinção de espécies; o aumento de contigentes populacionais humanos vivendo na pobreza e na miséria (material, moral e espiritual); o surgimento de doenças relacionadas à poluição e ao estresse da vida moderna; as crises que geram a falta de desemprego ou de trabalho remunerado, da noite para o dia, em diversos países, muitas vezes por razões surgidas fora de seus territórios. 
Essa dicotomia, de produção assimétrica de bem-estar, favorecendo poucos e criando desafios para a sobrevivência física e cultural de muitos, observa-se também no Brasil. Dois dos exemplos brasileiros são a destruição da Mata Atlântica e o desequilíbrio entre as condições de pobreza da vida da população rural da região do Vale do Ribeira, do Estado de São Paulo e a riqueza e a beleza das áreas remanescentes da Mata Atlântica dessa região. De um lado, essa população rural vive em condições de vida economicamente inadequadas, o que muitas vezes leva a alterações psicológicas conforme atestam vários depoimentos de moradores dessa região (BORN, 1995):

"Eu fiquei muito chateado porque nunca tive multa. Tenho vergonha. Não consigo nem trabalhar direito. Se eu tivesse esse dinheiro eu pagaria, mas não tenho nada." (Sr. $\mathrm{G}^{1}$ ). O morador da Juréia-Itatins e um dos guias do Projeto Juréia-Itatins se referia à multa recebida da Polícia Florestal por ter feito sua roça, usando técnicas da agricultura itinerante e também por ter sido denunciado por guardas-parque, antes amigos e parentes.

"É necessário andar escondido pelos matos e na dependência dos baixos preços pagos pelos poucos compradores da cidade de (...) que antes nós tínhamos liberdade para tirar e vender. A gente se vê obrigado a tirar uma maior quantidade e como nós podemos ser pegos pela fiscalização, temos que ser rápidos." (Sr. I). O morador da Juréia-Itatins e um dos guias do Projeto Juréia-Itatins se referia à extração e à comercialização de palmito (Eutherpe edulis) e à fiscalização dentro da Estação ecológica de Juréia-Itatins.

Esse desequilibrio gera várias dificuldades para a obtenção da compatibilidade entre a utilização da beleza cênica e das riquezas biológicas, genética e ecológicas da Mata Atlântica pela população local, principalmente a rural, para melhorar as suas condições de vida, e a conservação dos recursos naturais e da dinâmica dos

${ }^{1}$ Para garantir o anonimato, os entrevistados no Projeto Juréia-Itatins (BORN, 1995) e no Projeto Da mata à casa serão denominados de A, B, C... 
ecossistemas que compõem esse bioma.

A política de conservação voltada para criar unidades de conservação de uso restrito, em áreas já habitadas há várias gerações por populações humanas, tem levado a conflitos diversos, envolvendo autoridades, como prefeitos e vereadores, e pessoas das comunidades da região do Vale do Ribeira, que resistem a essa forma de abordagem usada para conservar a Mata Atlântica. Isso pode ser verificado no seguinte depoimento, obtido por BORN (1995):

"Eles [O entrevistado identificou "eles" como pessoas da cidade e acrescentou que alguns deles eram técnicos do Ibama e do governo estadual, vereadores e ecologistas.] andavam por aí, para cima e para baixo. Eles não perguntaram à gente se a gente queria ou não essa tal ecologia [referia-se à criação da Estação Ecológica de Juréia-Itatins.] . Hoje, eu sei que a estação ecológica não é boa para gente. Agora, a gente não pode fazer nada aqui." (Sr. J).

Em relação às autoridades municipais, como prefeitos e vereadores, essa situação tem mudado após a aprovação e a implementação de um instrumento para a compensação financeira dos municípios, que mantêm em seu território áreas protegidas, criadas pelo Estado, na forma de unidades de conservação. Através desse mecanismo, em vigor desde 1994, segundo GOVERNO DO ESTADO DE SÃO PAULO (1997), as prefeituras da região do Vale do Ribeira já receberam cerca de 9 milhões de reais, por ano a mais, sob forma de repasses de tributos. Além de investimentos municipais, esse instrumento tem mobilizado, na prática, algumas ações de conservação e conscientização ambiental.

As dificuldades para a conservação e o uso sustentável dos recursos naturais agravam-se com a falta de conhecimento das riquezas da Mata Atlântica e de sua dinâmica. A falta de uma política clara que integre a conservação da biodiversidade com a melhoria da qualidade de vida das populações que vivem em áreas de interesse para a conservação desse bioma também contribuem para agravar a situação. Tais fatores têm levado profissionais liberais, políticos e pessoas de comunidades rurais localizadas em áreas remanescentes da Mata Atlântica, na região do Vale do Ribeira, a duvidarem da 
possibilidade de usar parte da riqueza desse bioma para a promoção e melhoria das condições de vida, como pode ser verificado no seguinte depoimento, obtido por BORN (1999a):

"Todos os que vêm aqui dizem que a Mata Atlântica é rica e que nós poderíamos usar essa riqueza. Mas eles vão embora $e$ nós continuamos vivendo do mesmo jeito, sem condições de vida boa". (Sra. H).

Esse depoimento não significa que a população dessa região não se orgulhe em viver na Mata Atlântica, mas, provavelmente, membros da população, especialmente, da rural, estão desestimulados e, até mesmo, cansados das dificuldades por eles enfrentadas para ai continuarem vivendo (BORN, 1995).

Não obstante, as riquezas e a beleza da Mata Atlântica têm deixado alguns poucos de seus moradores orgulhosos de lá viverem. O Sr. Sátiro Tavares da Silva (1927-1995), curandeiro e líder espiritual e político da Estação ecológica de Juréia-Itatins, referia-se à Mata Atlântica como sendo uma "farmácia" onde podiam ser encontradas plantas e materiais de origem animal usados pela população local, principalmente por ele mesmo, para fazer remédios para muitos problemas de saúde: "Nós vivemos dentro de uma farmácia fresca. Por que não usá-la?" (BORN et. al., 1989; BORN, 1995).

De fato, a extração e o uso de plantas medicinais da Mata Atlântica pela população da região do Vale do Ribeira ocorrem tanto na prática da medicina popular como na obtenção ou complementação da renda familiar.

A extração e a comercialização de plantas medicinais da Mata Atlântica, da região do Vale do Ribeira, Estado de São Paulo, têm despertado interesse, preocupação e curiosidade entre alguns moradores dessa região e também entre aqueles que lá trabalham. Sabe-se que há exploração de plantas medicinais, encontradas naturalmente na Mata Atlântica, com base em métodos tradicionais, ou seja, métodos desenvolvidos e usados por extratores de plantas medicinais da região do Vale do Ribeira. Essa extração é considerada intensa e crescente, em decorrência do aumento tanto do número de extratores quanto da quantidade de material extraída. Uma das lideranças do grupo de 
extratores e produtores de plantas medicinais da região previu, em 1994, que:

"Daqui a 50 anos não terá mais plantas medicinais no Vale. Só que a gente sabe, é extraído 450 toneladas por mês de material fresco" (BORN et al., 1995).

No início de 1999, essa liderança acrescentou que:

"Olhe! Do jeito que vai o desmatamento, não dou mais 50 anos para acabarem com as plantas medicinais do Vale do Ribeira. Quando estimei para você [referiu-se a mim] naquela época [referiu-se ao ano de 1994, quando deu o primeiro depoimento relatado acima], dei muito tempo." (Sr. B).

A liderança referia-se às derrubadas das áreas de mata onde se realizava a extração de plantas medicinais, principalmente, em uma área de derrubada à margem da rodovia federal Régis Bittencourt (BR-116), que ficava bem próximo à residência e à estação de beneficiamento de plantas medicinais dessa liderança.

Apesar do avanço na legislação brasileira e das discussões sobre conservação e uso sustentável de recursos naturais renováveis, são inexistentes estudos, à luz da ciência ocidental, voltados para a obtenção de dados e indicadores que possam ser usados em planos de manejo sustentável de espécies medicinais de Mata Atlântica. Não tendo tais dados nem indicadores, consequentemente, o Poder Executivo, representado pelo DEPRN (Departamento Estadual de Proteção de Recursos Naturais) e pelo Ibama (Instituto Brasileiro de Meio Ambiente e dos Recursos Naturais Renováveis), não pode exercer suas funções de orientação e fiscalização da exploração e comercialização de recursos naturais renováveis.

A falta desses indicadores revela-se como problema, uma vez que o Decreto Federal $n^{0} 750 / 93$, que dispõe sobre o corte, a exploração e a supressão da vegetação da Mata Atlântica, diz que: "A exploração e a comercialização de recursos naturais devem ser feitas com base em planos de manejo, elaborados a partir de parâmetros 
cientificos.".

O Decreto $\mathrm{n}^{\mathrm{0}}$ 750/93, foi editado após intensos debates e negociações entre técnicos governamentais, ambientalistas, proprietários rurais, comunidades locais, entre outros, e em substituição a um decreto anterior, de caráter muito mais restritivo. A Constituição Federal de 1988, ao apontar a Mata Atlântica como uma das áreas de patrimônio nacional, deveria ter impulsionado ações e estudos para a correção dos usos feitos dos recursos da Mata Atlântica.

As preocupações de membros da população do Vale do Ribeira, de pessoas e instituições que lá trabalham com relação à destruição da Mata Atlântica são procedentes também à luz das perdas causadas em conseqüência da crescente degradação. Podem ser detectados e destacados os seguintes pontos:

- perda da diversidade biológica e genética quase desconhecida no meio científico (BORN et al., 1989);

- perda irrecuperável de espécies da flora e da fauna endêmicas ${ }^{2}$ da Mata Atlântica (LINO, 1992; BORN \& RODRIGUES, 1998; BRASIL/MINISTÉRIO DO MEIO AMBIENTE, DOS RECURSOS HÍDRICOS E DA AMAZÔNIA LEGAL, 1998);

- impactos nos processos ecológicos, encontrados nos ecossistemas, essenciais à vida (MYERS, 1992);

- perda da diversidade cultural dos povos que vivem e dependem de recursos e da natureza encontrados na Mata Atlântica (BORN et al., 1989);

- empobrecimento, tanto econômico quanto em auto-estima, das populações que vivem em áreas de florestas, e que se vêem obrigadas a sair do meio em que nasceram e se criaram, para ir morar em bolsões de pobreza de cidades vizinhas às áreas de floresta (BORN, 1995; VITAE CIVILIS, 1995 e 1999);

- perda do uso de plantas medicinais na medicina popular e também na obtenção ou complementação de renda da família (AKERELE et al., 1991).

A destruição ambiental tem uma dimensão material e uma outra imaterial. A material está relacionada às perdas genéticas, biológicas, ecológicas, entre outras. A imaterial, por sua vez, está relacionada ao conhecimento e sabedoria das populações que

${ }^{2}$ Endemismo refere-se as espécies que ocorrem preferencialmente ou apenas em um determinado bioma, região etc. 
vivem nas florestas e dependem dos recursos materiais e da natureza para viverem. Como conseqüência, as dimensões material e imaterial levam também à perda da saúde individual, coletiva e ambiental dos grupos humanos que habitam tais regiões, tomandose como referência o conceito de saúde da Organização Mundial da Saúde, lançado em 7 de abril de 1947: "Saúde é o estado de mais completo bem-estar fisico, mental $e$ social, e não apenas a ausência de enfermidade." (SCLIAR, 1987).

Os problemas da destruição e da conservação ambiental, bem como suas conseqüências para a qualidade de vida das populações são geralmente enfrentadas com base em abordagens fragmentadas, que resultam em ações desarticuladas nos diferentes campos.

No campo da saúde, a atenção e os esforços concentram-se principalmente na organização e na eficiência dos serviços médico-ambulatoriais de saúde, bem como em pesquisas e instrumentos aplicáveis à biologia humana, como, por exemplo, vacinas.

No campo ambiental, a estratégia predominante tem-se baseado, nas três últimas décadas, em dois pilares: a criação de unidades de conservação e a aplicação de um sistema regulatório dos recursos naturais, exercida pelo Estado.

A estratégia mais usada para preservar e conservar a diversidade biológica foi a criação de unidades de conservação, também denominadas de áreas ambientalmente protegidas ou "espaços territoriais" (CONSTITUIÇÃO DO BRASIL, 1988). Essas "áreas significativas ou relevantes" ou ainda conhecidas como "ilhas da natureza" (BORN,1994; DIEGUES, 1996) são criadas com base em seus atributos como dimensão, características da biota e dos ecossistemas, existência de espécies raras ou ameaçadas, intocabilidade humana, entre outros. A intocabilidade humana é geralmente considerada um fator muito importante, pois parte da premissa, muitas vezes não explicitada, de que toda interferência humana no ambiente é negativa e deletéria à conservação dos recursos naturais.

Quanto ao sistema regulatório exercido pelo Estado, comandando e controlando o acesso aos recursos naturais, este tem apresentado resultados questionáveis, ineficientes e conflitantes.

Diante do panorama apresentado, caberia perguntar se há outras estratégias e alternativas para a conciliação do uso, doméstico ou comercial, de recursos naturais renováveis com sua conservação, assim como, com a dinâmica existente nos ecossistemas onde se encontram tais recursos. Acredita-se que isso seja possível com a 
sustentabilidade do desenvolvimento, ou seja, a relação harmoniosa entre desenvolvimento e meio ambiente.

A partir das décadas de 1970 e 1980, intensificaram-se os debates sobre a relação entre desenvolvimento e meio ambiente. Dentre os resultados desse processo, destacam-se as discussões e a disseminação do conceito de sustentabilidade, assim como, a busca e o uso de estratégias que possibilitem, de fato, termos 0 desenvolvimento sustentável. Como essência, surgiu a noção de que o ambiente deve ser manejado em escala e taxas tais que a geração atual e as futuras possam valer-se de condições adequadas para satisfazer suas necessidades com base nos recursos naturais e na salubridade ambiental disponiveis. Poderiam ser extraídos, portanto, recursos naturais renováveis em formas e taxas capazes de manter seu estoque, sua função e sua dinâmica ecológica, respeitando, assim, o "capital" da natureza.

Surgiram, a partir daí, vários conceitos e interpretações sobre sustentabilidade do desenvolvimento (ver 3.1 - Sustentabilidade do desenvolvimento). Serão introduzidos aqui os conceitos que mais marcaram a trajetória dessa definição.

SACHS (1986) definiu ecodesenvolvimento como sendo "o desenvolvimento que considera sempre a interação dos processos naturais, sociais, culturais, econômicos, legais e politicos, de maneira integrada, para que se possam ter sociedades sustentadas ou pelo menos sociedades com menor desigualdade social, compostas por cidadãos(ãs) conhecedores(as) e conscientes de sua cidadania, do respeito às diferenças culturais e étnicas, entre outros".

Em 1987, a Comissão Brundtland definiu desenvolvimento sustentável como sendo "o desenvolvimento que atende às necessidades básicas da geração atual sem comprometer a capacidade das gerações futuras atenderem às suas, observados os limites e a capacidade dos processos ambientais" (COMISSÃO MUNDIAL SOBRE MEIO AMBIENTE E DESENVOLVIMENTO, 1988).

Com o processo da Rio-92, vinte anos após a Conferência de Estocolmo-72, multiplicaram-se as interpretações e formulações da expressão desenvolvimento sustentável. No bojo do processo da Conferência do Rio, surgiu a noção de "sociedade sustentável" (BORN, 1998).

No documento intitulado Cuidando do Planeta Terra: Uma Estratégia para o Futuro da Vida, elaborado por UICN; PNUMA \& WWF, em 1991, o termo "sociedade sustentável", refere-se a uma tentativa de resgatar a questão do rumo, e não somente da 
forma qualitativa do desenvolvimento (BORN, 1998).

Nesse conceito, "sociedade sustentável" é a sociedade que vive segundo os seguintes princípios (IUCN, PNUMA e WWF, 1992):

1. respeitar e cuidar da comunidade dos seres vivos;

2. melhorar a qualidade da vida humana;

3. conservar a vitalidade e a diversidade do planeta Terra;

4. minimizar o esgotamento de recursos não-renováveis;

5. permanecer nos limites da capacidade de suporte do planeta Terra;

6. modificar atitudes e práticas pessoais;

7. permitir que as comunidades cuidem de seu próprio meio ambiente;

8. gerar uma estrutura nacional para a integração de desenvolvimento e conservação;

9. constituir uma aliança global.

Nesse caso, o desenvolvimento é considerado como um meio para se chegar a uma situação desejada ou utópica, ou seja, o desenvolvimento sustentável é "o processo para melhorar a qualidade de vida humana, respeitando a capacidade de suporte dos ecossistemas" (IUCN, PNUMA \& WWF, 1992).

Tendo como abordagem, filosofia e princípio a busca da sustentabilidade do desenvolvimento como processo para ser criada uma sociedade sustentável, acredita-se que as riquezas e belezas da Mata Atlântica podem ser usadas pela população local, principalmente a rural, para conseguir condições dignas de vida. Essa utilização deveria ser realizada com base nos princípios da sustentabilidade do desenvolvimento e considerar a integração das dimensões econômica, social, ambiental, política (nacional, local, internacional) e cultural, tendo em vista a durabilidade dos recursos naturais renováveis e a manutenção da dinâmica dos ecossistemas.

Entre os vários recursos naturais renováveis da Mata Atlântica que podem ser usados para a melhoria da qualidade de vida de populações rurais e para a conservação desse bioma, na região do Vale do Ribeira, destacam-se as plantas medicinais.

Assim, esta tese pretende analisar a sustentabilidade do uso comercial de plantas medicinais da Mata Atlântica como um dos meios para a consecução da sustentabilidade do desenvolvimento da região do Vale do Ribeira. Essa análise será realizada à luz das diferentes dimensões e esferas da sustentabilidade do desenvolvimento, com destaque para as questões envolvidas no estudo de caso sobre a extração e a comercialização de 
plantas medicinais já realizadas na região do Vale do Ribeira.

A hipótese dessa tese, portanto, é que a extração e a comercialização de plantas medicinais podem ou poderão contribuir para a sustentabilidade do desenvolvimento na Mata Atlântica, mais especificamente na região do Vale do Ribeira, no Estado de São Paulo.

Dois objetivos gerais foram elaborados para orientar a realização desta tese. Um foi verificar e avaliar se a extração e a comercialização de plantas medicinais podem ou poderão contribuir para a sustentabilidade do desenvolvimento na Mata Atlântica, na região do Vale do Ribeira, Estado de São Paulo. O outro, foi verificar e avaliar se há sustentabilidade na extração e na comercialização das plantas medicinais realizadas pelos extratores e produtores de plantas medicinais da região do Vale do Ribeira, Estado de São Paulo, valendo-se do diagnóstico etnobotânico como estratégia e instrumento para conhecer e documentar os métodos tradicionais para identificação, extração, transporte, beneficiamento e comercialização de plantas medicinais.

Os objetivos específicos considerados foram:

1. Levantar as técnicas tradicionais usadas pelo grupo em estudo para identificação das plantas, extração, beneficiamento, transporte e comercialização;

2. Levantar alguns aspectos sociais, econômicos e culturais do grupo, buscando tendências e opiniões no que se refere ao contexto da prática de extração e comercialização de plantas medicinais e de sua conservação;

3. Coletar amostras das plantas citadas e identificadas pelos entrevistados assim como realizar a identificação botânica dessas plantas;

4. Identificar as áreas utilizadas para extração;

5. Buscar na literatura especializada a origem das espécies medicinais levantadas e os principais trabalhos sobre ação farmacológica e propriedade fitoquímica dessas espécies;

6. Organizar, interpretar e analisar os dados levantados. 


\section{O CONTEXTO E A GÊNESE DA TESE}

A presente tese é parte de um projeto conhecido como Da mata à casa, que está sendo desenvolvido pelo Vitae Civilis, sob minha coordenação e planejamento. Serão apresentadas algumas informações sobre o Vitae Civilis e sobre a gênese do projeto $D a$ mata à casa e da Aepam - Associação de Extratores e Produtores de Plantas Aromáticas e Medicinais do Vale do Ribeira - para contextualizar fatores e processos de relevância que levaram à escolha do tema desta tese.

\subsection{O Vitae Civilis}

O Vitae Civilis - Instituto para o Desenvolvimento, Meio Ambiente e Paz - é uma organização não-governamental, sem fins lucrativos, fundada em 1989, com sede na cidade de São Paulo e com uma base de campo no município de Registro, Vale do Ribeira, Estado de São Paulo.

As informações apresentadas neste item foram obtidas por meio de material de divulgação do Vitae Civilis, além de bibliografias citadas no texto.

Para superar grandes desafios, como a obtenção de justiça social, de eqüidade entre indivíduos e nações e de equilíbrio e salubridade ambiental, assim como a erradicação da violência, é necessário, segundo o Vitae Civilis, a concretização de esforços globais e locais para criar e consolidar sociedades sustentáveis, isto é, que possuem sustentabilidade em seu desenvolvimento.

Frente aos desafios, o Vitae Civilis escolheu como sua missão, servir de instrumento para construção de sociedades sustentáveis.

Entre os objetivos especificos do Vitae Civilis para a sustentabilidade do desenvolvimento, a conservação do meio ambiente e o estabelecimento de sociedades sustentáveis, destacam-se:

a. promover e estabelecer estudos e atividades, visando a implantação de políticas e programas; 
b. estabelecer programas de assistência técnica e treinamento para organizações nãogovernamentais, grupos, comunidades, entre outros;

c. fomentar iniciativas de fortalecimento da cidadania e participar delas por meio de articulações e parcerias com comunidades e grupos organizados de cidadãos;

d. colaborar para estimular a formação e o fortalecimento, bem como participar de redes nacionais e internacionais, que se articulem com organizações nãogovernamentais que atuem no âmbito das finalidades do Vitae Civilis.

A estratégia de ação adotada busca o fortalecimento da democracia. Para isso, o instituto dissemina informações, colabora com a construção da cidadania, realiza estudos e propostas, age e coopera com parceiros. As quatro linhas básicas de atuação e de desenvolvimento de seus programas e projetos são:

a. conscientização e educação ambiental: difusão de conhecimentos e informações para capacitar a ação cidadã de indivíduos e grupos em questões de desenvolvimento e meio ambiente;

b. fortalecimento e parcerias com a sociedade: apoio e assessoria à formação, organização, mobilização e atuação de grupos da sociedade civil; construção de parcerias por meio da participação e do fortalecimento de redes e grupos de ONGs e movimentos sociais;

c. tecnologia e ciência: desenvolvimento de atividades, estudos e pesquisas, inovadoras ou catalisadoras de processos replicáveis de gestão sustentável do ambiente, e distribuição justa dos benefícios decorrentes;

d. participação, eqüidade e transparência: acompanhamento, análise e atuação em políticas públicas e ambientais, programas e ações governamentais e privados; fortalecimento das instâncias participativas, buscando a democratização das decisões.

As atividades do Vitae Civilis são organizadas de forma integrada em seus três programas:

1. Desenvolvimento rural sustentável, conservação da biodiversidade e proteção cultural (Programa Bio-rural);

2. Gestão sustentável de áreas urbanas (Programa Urbano) e

3. Globalização e componentes locais das questões de desenvolvimento e de meio 
ambiente (Programa Global/Local).

Com o Programa Bio-rural, o Vitae Civilis pretende contribuir para um cenário de desenvolvimento e organização de populações rurais e tradicionais compatível com suas características culturais e com a exploração sustentável de recursos vegetais nãomadeireiros, assim como com a conservação da biodiversidade. Esse programa tem como base as seguintes linhas:

- suporte a iniciativas sustentáveis para a melhoria da qualidade de vida de populações em áreas rurais e de proteção ambiental;

- compreensão, organização, obtenção e compatibilização do conhecimento empírico e científico para a gestão sustentável da biodiversidade e para contribuir na promoção da sustentabilidade do desenvolvimento;

- estender o desenvolvimento sustentável à população rural e tradicional.

A estratégia de ação, em campo, apoia-se em uma abordagem metodológica de pesquisa participativa, cooperação e no compromisso ético de retornar os resultados às populações e instituições envolvidas. Essa estratégia parte da premissa de que é necessário compatibilizar as diversidade cultural e biológica para a consecução da sustentabilidade do desenvolvimento. Para atingir essa meta junto às comunidades locais, à sociedade civil e ao governo, as linhas de ação envolvem resgate e análise de conhecimentos tradicionais, geração de tecnologias, catalisação e atuação na implementação de propostas científicas com base em aspectos ecológicos, sociais, culturais, econômicos e legais. A área primária de atenção é o bioma Mata Atlântica, priorizando, até o momento, a região do Vale do Ribeira.

Com o programa Globalização e componentes locais das questões de desenvolvimento e de meio ambiente (Programa Global/local), o Vitae Civilis integra estudos e ações de seus Programas Urbano e Bio-rural. Além disso, o Vitae Civilis atua nas inter-relações das questões globais, nacionais e locais determinantes das políticas e condições de desenvolvimento e conservação ambiental, considerando as seguintes linhas:

- acompanhamento e atuação na formulação e no monitoramento da implementação de políticas ambientais;

- acompanhamento, análise e atuação na implementação, nos diversos níveis, de acordos internacionais de desenvolvimento sustentável e meio ambiente, 
especialmente aqueles resultantes da Rio-92 (Convenções de Diversidade Biológica e de Mudança de Clima);

- implementação e disseminação da Agenda 21;

- impactos locais de questões globais e inserção global de questões locais.

Serão relatadas, a seguir, as principais atividades dos projetos desenvolvidos em áreas remanescentes de Mata Atlântica da região do Vale do Ribeira, Estado de São Paulo, e no âmbito dos Programas Bio-rural e Global/Local.

\section{- Projeto Juréia-Itatins}

Esse projeto foi realizado na Estação ecológica de Juréia-Itatins, localizada em áreas dos municípios de Iguape, Miracatu, Itatiri, Pedro de Toledo e Peruíbe, região do Vale do Ribeira, Estado de São Paulo, junto às suas comunidades tradicionais da Cachoeira do Guilherme, Aguapeú, Grajaúna, Praia do Una, Rio Verde, Rio Comprido, Rio das Pedras, Serra e parte do Despraiado, no período de 1989 a 1995.

Estação ecológica é uma categoria de unidade de conservação que legalmente não contempla a presença de assentamentos de grupos humanos em seu interior (ver 4.2. A região do Vale do Ribeira). A Estação ecológica de Juréia-Itatins, porém, é habitada por comunidades que ali vivem há décadas, realizando atividades de sobrevivência relacionadas ao uso dos recursos naturais. $\mathrm{O}$ conhecimento tradicional lá existente é, desta forma, muito rico, graças à cultura das comunidades que ali residem.

O projeto Juréia-Itatins teve os seguintes objetivos atingidos:

- diagnosticar o conhecimento etnofarmacológico e etnobotânico dessas comunidades;

- estudar alguns aspectos das condições sociais, econômicas, culturais, ambientais e políticos dessas comunidades;

- contribuir para a conservação ambiental e o desenvolvimento local sustentável;

- diagnosticar reivindicações mais emergentes dessas comunidades e buscar, junto às comunidades e às instituições envolvidas, estudar a viabilização do atendimento dessas reivindicações;

- realizar os primeiros estudos para definir métodos de amostragem para manejo sustentável de plantas medicinais da Mata Atlântica; 
- contribuir para o fortalecimento das populações locais de forma que elas pudessem adquirir posicionamentos e atitudes que levassem à melhoria de sua qualidade de vida, preservando seus valores.

Inicialmente, foi realizado um amplo levantamento etnobotânico, etnofarmacológico, bem como das condições sociais, culturais, econômicas, políticas e ambientais das comunidades entrevistadas. Esses levantamentos possibilitaram o resgate e a documentação de rico conhecimento sobre a relação das comunidades com a natureza e sobre o uso de recursos naturais, de origem animal e especialmente vegetal, usados por aquelas comunidades para sua subsistência. Foram resgatados e documentados, também, importantes aspectos, referidos anteriormente, que mostraram como as comunidades viviam e quais eram suas principais reivindicações para alcançarem melhores condições de vida, do ponto de vista das próprias comunidades (VITAE CIVILIS, 1995; BORN et al., 1996).

Fazendo parte da abordagem da pesquisa (orientada à ação) e do compromisso ético do Vitae Civilis com as comunidades da Juréia-Itatins, foi feita uma apresentação dos dados fornecidos pelos entrevistados e analisados para a população da Estação ecológica de Juréia-Itatins. Essa apresentação foi realizada no dia 29 de setembro de 1993, durante a festa de São Miguel Arcanjo, realizada anualmente na comunidade da Cachoeira do Guilherme. Essa é uma das grandes festas realizadas na Juréia-Itatins, e reverencia o santo padroeiro da comunidade da Cachoeira do Guilherme. Durante a festa de São Miguel Arcanjo, há rezas, casamentos, batizados e curas (BORN, 1995).

Para expor e explicar a apresentação, contamos com o apoio de dois membros de duas comunidades estudadas, que fizeram parte da equipe do projeto Juréia-Itatins: Dauro Prado e Orlando Martins Tavares. Durante o preparo dessa apresentação, várias pessoas da comunidade da Cachoeira do Guilherme estiveram envolvidas. Algumas delas foram envolvidas durante a consulta do Vitae Civilis à comunidade para saber como apresentar tais dados de maneira que os presentes entendessem a apresentação e também participassem dela. Várias outras foram envolvidas durante a preparação de grande parte do material usado na apresentação.

Um grupo do Vitae Civilis, do qual eu fazia parte, como coordenadora, ouviu primeiramente o líder espiritual e político das comunidades da Juréia-Itatins, Sr. Sátiro Tavares da Silva, não apenas por ele ser o líder da comunidade, mas principalmente pelo bom senso, equilíbrio e coerência que sempre marcaram suas idéias. Depois, o 
grupo ouviu os dois nativos e moradores da Juréia-Itatins, anteriormente mencionados, e a professora da Escola Municipal da Cachoeira do Guilherme, neta do Sr. Sátiro. Com base nesses contatos, o Vitae Civilis definiu o dia, o horário e a forma da apresentação do trabalho (BORN et al., 1996).

Em um segundo momento, duas comunidades foram selecionadas e mobilizadas para que fossem facilitadas ações integradas de modo a viabilizar o atendimento das duas reivindicações daquelas comunidades consideradas mais prioritárias: mais opções de obtenção de renda e melhor atendimento à saúde (BORN et al., 1996).

Para tanto, buscou-se viabilizar, junto às comunidades selecionadas (Cachoeira do Guilherme e Aguapeú), o cultivo, o beneficiamento e a comercialização de plantas medicinais preexistentes na estação ecológica. Com base em conversas com técnicos do órgão estadual responsável pela gestão da Juréia-Itatins, seriam utilizadas as áreas já "antropizadas", nas quais o cultivo de subsistência vinha sendo "tolerado". Foi tentado também viabilizar a implantação de um posto de saúde com um agente comunitário de saúde e atividades para o fortalecimento comunitário. Realizamos, também, os primeiros estudos para obtenção de métodos de amostragem e de regeneração visando o manejo sustentável de plantas medicinais da Mata Atlântica (BORN, 1998).

Apesar das comunidades tradicionais da Juréia-Itatins valerem-se muito de sua medicina popular, o isolamento dessas comunidades e a ausência de uma estrutura para atendimento à saúde faziam dessa questão uma constante reivindicação da população residente.

Para catalisação da demanda por melhor atendimento à saúde, o Vitae Civilis contatou órgãos governamentais da região e do Estado, visando a implantação de um posto de saúde para atender a comunidade da Cachoeira do Guilherme e outras próximas. Após o consentimento do líder religioso e político da citada comunidade, o Vitae Civilis coordenou um processo de cooperação entre a comunidade, o Vitae Civilis, a Secretaria Estadual da Saúde (por meio do Escritório Regional da Saúde, antigo ERSA-49), a Prefeitura Municipal de Iguape e o Instituto Florestal. O processo gerou:

- a participação democrática da comunidade na definição de seu agente comunitário de saúde;

- a escolha de um membro da comunidade da Cachoeira do Guilherme para atuar 
como agente comunitário de saúde;

- o treinamento, prático e teórico, desse agente pela Secretaria Estadual de Saúde;

- a contratação do agente comunitário de saúde pela Prefeitura do Município de Iguape;

- a elaboração de um projeto, pelo Vitae Civilis, para a construção de um posto de saúde na Juréia-Itatins, tendo sido a verba para esse projeto aprovada por um doador nacional.

A escolha do agente comunitário de saúde resultou da mobilização da comunidade da Cachoeira do Guilherme, catalisada pelo Vitae Civilis. Em conjunto com a Secretaria de Saúde do Estado, a comunidade escolheu três dos seus membros, os quais realizaram um concurso público composto por prova escrita, entrevista e votos da comunidade. Nesse concurso, o peso dos votos da comunidade foi maior do que o da prova e o da entrevista. O selecionado no concurso foi, portanto, o mais votado por sua comunidade. Ele recebeu treinamento em medicina preventiva, valorização dos hábitos culturais da comunidade, compatibilização de práticas da medicina popular (ou tradicional) com a medicina moderna (ou convencional), e em outros aspectos próprios da formação de agente comunitário de saúde. O agente comunitário de saúde, Nilson Tavares Martins, neto do Sr. Sátiro, além de dar assistência básica às comunidades em medicina preventiva e curativa, nos limites de sua função, tem também a função de fazer a articulação das demandas junto à Secretaria de Saúde do Estado, à Prefeitura de Iguape e às comunidades assistidas.

Entretanto, não foi possível instalar o posto de saúde porque o órgão governamental responsável pela administração da Estação ecológica de Juréia-Itatins, Instituto Florestal da Secretaria Estadual do Meio Ambiente, não autorizou formalmente sua instalação, apesar de o Vitae Civilis ter obtido os recursos financeiros para sua construção e ter garantido que o posto seria doado ao Estado de São Paulo.

Um segundo resultado obtido a partir das ações realizadas no âmbito do projeto Juréia-Itatins, visando a melhoria da qualidade de vida das famílias das duas comunidades selecionadas, Cachoeira do Guilherme e Aguapeú, e a conservação da Mata Atlântica, foi o cultivo de plantas medicinais por essas comunidades. Havia a idéia, naquelas comunidades, de que alguns recursos naturais encontrados nas áreas onde habitavam há várias gerações, poderiam ser usados para satisfazer necessidades de 
complementação de renda de suas famílias. Entre os recursos naturais, destacavam-se as plantas medicinais. Os estudos e as ações de apoio para o cultivo e o uso sustentável de plantas medicinais consideraram:

1. conhecimento por parte dos moradores das comunidades sobre plantas medicinais;

2. várias dessas plantas medicinais já eram amplamente encontradas espontaneamente ou cultivadas; tendo sido, pois, introduzidas na estação ecológica há muito tempo;

3. possibilidade de cultivo, sem o uso de agrotóxico e/ou adubo químico, de plantas medicinais em áreas da Estação ecológica de Juréia-Itatins que já eram usadas pelos próprios moradores para fazer suas roças de subsistência e seus pomares.

Com esses aspectos que favoreciam o cultivo, o manejo sustentável e a comercialização de produtos de plantas medicinais, realizou-se, em 1992, um levantamento de aspectos do mercado de plantas medicinais na região metropolitana de São Paulo para se saber, em um primeiro momento, quem comprava plantas medicinais, por quanto e como era feito o pagamento, o que costumava ser comprado, em que quantidade e com qual freqüência (BORN, 1999).

Um outro importante resultado obtido, o mais importante para as comunidades da Cachoeira do Guilherme e do Aguapeú, foi que ao final desse trabalho os membros dessas duas comunidades estavam tendo maior envolvimento e posicionamento crítico em relação às suas necessidades e perspectivas de desenvolvimento. Durante o desenvolvimento dessas ações, o Vitae Civilis mobilizou a população das duas comunidades por meio de encontros individuais e coletivos, durante os quais realizou por meio de dinâmica de grupo o envolvimento das mulheres e dos homens das comunidades, permitindo que ambos expressassem suas opiniões e realizassem ações concretas para o seu desenvolvimento (BORN et al., 1996).

Finalmente, outro resultado foi que o projeto Juréia-Itatins proporcionou o surgimento de três outros projetos: o Da mata à casa (ver 2.3 - O projeto Da mata à casa), o projeto Percepção de Direitos de Uso de Recursos Naturais e de Propriedade Intelectual: $O$ caso Juréia e o projeto Pesquisa e Intercâmbio Etnobotânico entre Vietnã e Brasil (VITAE CIVILIS, 1995; BORN et al., 1996a). Esses projetos geraram dados e informações que são utilizados neste estudo e que contribuíram para ampliar os horizontes de conhecimento e as ações para a sustentabilidade do desenvolvimento na região do Vale do Ribeira. 
- Projeto Percepção de Direitos de Uso de Recursos Naturais e de Propriedade Intelectual: O Caso Juréia

O projeto Juréia-Itatins proporcionou duas reflexões. Uma tratou do direito de "propriedade intelectual" das comunidades entrevistadas sobre o seu conhecimento etnobotânico e, principalmente, etnofarmacológico e uma outra tratou dos direitos de acesso e uso de recursos naturais por aquelas comunidades.

Para realizar essas reflexões, o Vitae Civilis idealizou e realizou este projeto com o objetivo de identificar percepções de integrantes das comunidades tradicionais da Estação ecológica Juréia-Itatins e de outros atores sociais, conhecedores ou envolvidos com essa área protegida. Mais especificamente, o objetivo era identificar suas percepções no que se refere aos direitos, consuetudinários, formais ou potenciais, das referidas comunidades sobre a utilização e a gestão de recursos florestais, bem como sobre a utilização de seu conhecimento etnobotânico e etnofarmacológico por terceiros.

Este projeto visou também servir como estudo de caso para a discussão das formas e ações necessárias para fazer valer o disposto no inciso (j) do artigo $8 \mathrm{da}$ Convenção de Diversidade Biológica, assinada na Rio-92, que trata dos benefícios que comunidades tradicionais e indígenas devem receber em função da disposição de seus conhecimentos sobre uso e conservação de recursos naturais.

Entre os atores sociais consultados estavam representantes de: órgãos governamentais (Instituto Florestal da Secretaria Estadual do Meio Ambiente, Ibama, Instituto de Botânica do Estado de São Paulo); de organizações não-governamentais (Comissão Pró-Índio, Associação Pró-Juréia, Associação de Agricultura Orgânica, REBRAF, PROTER, União dos Moradores da Juréia-Itatins, Associação dos Extratores e Produtores de Plantas Medicinais e Aromáticas do Vale do Ribeira); representantes de ordem particular (mídia, jornalistas free-lance) e acadêmica (Núcleo de Apoio à Pesquisa sobre Populações Humanas e Áreas Úmidas Brasileiras, Universidade de São Paulo - NUPAUB/USP - e Universidade Estadual de Campinas - UNICAMP).

Esse estudo, realizado em 1995, mostrou que o Brasil não tinha, na época nenhuma legislação que garantisse a propriedade intelectual das comunidades tradicionais sobre seus conhecimentos. Os entrevistados, inclusive os das comunidades, 
foram unânimes em dizer que estas deveriam receber benefícios, financeiros ou não, decorrentes da utilização, com fins lucrativos, de seus conhecimentos. Constatou-se um grande desconhecimento do tema sobre o direito de propriedade intelectual. Isso mostra a necessidade de continuar, ampliar e aprofundar os debates sobre tais temas de forma a identificar e desenvolver ações junto às comunidades e a seus segmentos e, deste modo, garantir, legalmente, os benefícios que os detentores do conhecimento tradicional deveriam ter.

Por sua vez, o direito de uso e gestão de recursos naturais tem sido um tema muito discutido e, portanto, bem conhecido, e muito polêmico, tanto entre as comunidades como entre os representantes dos setores entrevistados. Não obstante, a existência de conflitos, que dificultam tanto o desenvolvimento das comunidades que habitam áreas protegidas, como a conservação da biodiversidade motiva e demanda o aprofundamento de reflexões. É uma tentativa de aprimorar instrumentos e encontrar novas alternativas para melhorar a gestão das áreas protegidas, aumentar a eficiência do uso de recursos naturais e ampliar a participação das comunidades nos processos de criação, implementação, gestão e avaliação de áreas protegidas.

\section{- Projeto Pesquisa e Intercâmbio Etnobotânico entre Vietnã e Brasil}

Em dezembro de 1991, o Vitae Civilis, por mim representado, foi selecionado pelo PNUD-NY (Programa das Nações Unidas para o Desenvolvimento, escritório de Nova York.) para participar de um workshop internacional sobre Intercâmbio Etnobotânico entre Amazônia e a Ásia, em Belém — PR.

Para dar continuidade ao trabalho de intercâmbio entre a América e a Ásia, em 1994, o PNUD-NY solicitou propostas conjuntas de pesquisadores da América e da Ásia, que tinham participado do referido workshop. Entre os dois únicos projetos brasileiros selecionados para receber o apoio financeiro do PNUD estava o do Vitae Civilis, em conjunto com a Faculdade de Biologia da Universidade de Hanoy (Vietnã).

A área de atuação no Brasil selecionada para servir de base para o estudo de caso, foi o Vale do Ribeira ou, mais especificamente, as comunidades tradicionais da estação ecológica da Juréia-Itatins e os extratores e produtores de plantas medicinais dessa região (Projetos Juréia-Itatins e Da mata à casa, respectivamente). 
A área da equipe do Vietnã foi a província de Hoa Binch, junto ao grupo étnico Muong, que tem como principal atividade para a obtenção de renda a extração e comercialização de plantas medicinais.

O intercâmbio teve como objetivo, a troca de experiências por meio da análise comparativa das abordagens metodológicas empregadas, dos aspectos socioeconômicoculturais das comunidades estudadas e dos mecanismos legais para a proteção da diversidade cultural e biológica dos dois países. Para isso, foi acordado entre as duas equipes (a do Vietnã, coordenada pela. Prof ${ }^{\mathfrak{a}}$. Dra. Nguyen Thi Quy, e a do Brasil, coordenada por mim) que os aspectos selecionados e os critérios a serem usados para a comparação entre os dois países seriam:

1. Dados sobre as comunidades, tais como: aspectos socioeconômico-culturais; dados etnofarmacológicos, práticas de extração e comercialização; população; padrões de assentamentos; aspectos sobre direito de propriedade intelectual das comunidades, além da aplicação da etnobotânica para mobilização e fortalecimento das comunidades;

2. Aspectos da legislação ambiental;

3. Relações entre ONGs, organizacões governamentais e comunidades;

4. Inventário e uso da biodiversidade florestal (plantas medicinais).

Para otimizar o desenvolvimento do projeto conjunto, fui ao Vietnã e, posteriormente, a Dra. Nguyen Thi Quy veio ao Brasil.

De maneira geral, ambos os grupos observaram que: "Os problemas são iguais e as possibilidades de soluções são semelhantes. No caso do Vietnã, a extração da natureza e a comercialização de planta medicinais são uma das principais atividades econômicas daquele país, principalmente para a comunidade Muong. No caso do Brasil, as práticas de extração e comercialização de plantas medicinais já são realizadas no Vale do Ribeira e há tendência de ampliação de tais atividades. Em nenhum dos paises há estudos de manejo sustentável de suas plantas medicinais. As duas equipes recomendaram, portanto, a realização de tais estudos; o cultivo, o enriquecimento de área e a valoração das plantas, realizando beneficiamento, controlando a qualidade dos produtos e procurando compradores que paguem preços melhores."( NGUYEN, 1995; BORN et al., 1996a). 
- Acompanhamento de políticas públicas e de outras iniciativas relativas à conservação da diversidade biológica e à sustentabilidade do desenvolvimento

O Vitae Civilis tem claro que para compatibilizar a proteção da diversidade cultural e biológica com o desenvolvimento social e econômico das populações humanas que habitam áreas remanescentes de Mata Atlântica, é necessário desenvolver, além das pesquisas orientadas para a ação, outras atividades de caráter mais global.. Assim, várias atividades complementares e inter-relacionadas desse instituto contribuíram - com dados, experiências e conhecimentos - não apenas para o aprimoramento dos trabalhos do próprio Vitae Civilis, como também para o enriquecimento desta tese.

O Vitae Civilis, desde o início de suas atuações em politicas ambientais e públicas, realiza o que segue:

- Participação em redes, como na coordenação da Rede de ONGs da Mata Atlântica e na do Fórum Brasileiro de ONGs e Movimentos Sociais para o Meio Ambiente e Desenvolvimento;

- Acompanhamento de projetos de lei e políticas públicas, como SNUC - Sistema Nacional de Unidades de Conservação (Projeto de Lei 2.892, de 1992), Conservação da Mata Atlântica (Projeto de Lei 3.285, de 1992), Acesso a Recursos Biológicos e Genéticos (Projeto de Lei 306, de 1995);

- Representação em instâncias, como no PRONABIO - Programa Nacional de Diversidade Biológica; no FUNBIO - Fundo Brasileiro de Biodiversidade; na CPDSA21 - Comissão Nacional de Política do Desenvolvimento Sustentável e Agenda 21;

- Participação em instâncias, como: Grupo Consultivo dos Núcleos Regionais de Educação Ambiental da SMA-SP; Comitê da Bacia Hidrográfica do Rio Ribeira de Iguape; Membro fundador do FSC - Forest Stewardishp Council International; Membro do GT - FSC do Brasil. 


\subsection{A gênese da Aepam}

Em 1992, li uma reportagem sobre os trabalhos de um extrator de plantas medicinais do Vale do Ribeira, chamado Carlos Alberto Novi. Naquela época, no Vitae Civilis, eu estava trabalhando com duas comunidades tradicionais da Estação ecológica de Juréia-Itatins, tentando apoiá-las no cultivo sustentável e na venda de plantas medicinais como uma forma de complementação de renda (ver 2.1 - O Vitae Civilis.). Procurei o Sr. Carlos Novi visando intercâmbio e apoio técnico quanto ao cultivo e à comercialização de plantas medicinais. O Sr. Carlos Novi muito gentilmente me recebeu e a partir daí começamos um trabalho conjunto. Ele constitui uma das lideranças da região do Vale do Ribeira, preocupado em conservar a Mata Atlântica e, ao mesmo tempo, usar a riqueza dessa mata para obter o sustento de sua família e o de outras que trabalham com ele.

Para conciliar o uso com a conservação e o cultivo de plantas medicinais, o Sr. Carlos Novi estudou muito e sozinho. Ele é um autodidata. Ele observava as reações das plantas a cada novo tratamento que ele lhes ministrava. Ele estuda sozinho, mas não trabalha sozinho: sua família participou e participa ativamente de seu trabalho. Sua esposa, Sra. Eleonita de Almeida Novi, trabalhou muito para conseguir o sustento da família na época em que o Sr. Carlos Novi estava apenas estudando a extração, o cultivo, o beneficiamento e a comercialização de plantas medicinais. Hoje, ela e uma das duas filhas trabalham junto com o Sr. Carlos Novi e administram os negócios com plantas medicinais.

Quando contatei o Sr. Carlos Novi, explicando que participava do Vitae Civilis, ele solicitou o apoio do Instituto para criar uma associação dos extratores e produtores de plantas aromáticas e medicinais. Fiquei muito contente porque eu tinha encontrado mais uma liderança do Vale do Ribeira com preocupação semelhante à do Vitae Civilis: saber conciliar o uso das plantas medicinais com a conservação da biodiversidade da Mata Atlântica.

O Sr. Carlos conseguiu fazer uma primeira reunião, da qual participaram representantes de todos os setores envolvidos com a exploração e comercialização de plantas medicinais. Nessa reunião estavam presentes alguns extratores e produtores de plantas medicinais, representantes de empresas ligadas a plantas medicinais, 
representantes da Polícia Florestal, representante do DEPRN, do Ibama, da universidade, agricultores do Vale do Ribeira e representantes de uma ONG - o Vitae Civilis. Essa foi a primeira reunião da Aepam - Associação de Extratores e Produtores de Plantas Aromáticas e Medicinais do Vale do Ribeira

De índole prática, o Sr. Carlos Novi abriu a reunião, em 27 de março de 1993, dizendo:

"Precisamos continuar trabalhando com as plantas medicinais, pois é a partir delas que tiramos o sustento das nossas familias. Queremos trabalhar dentro da legalidade. Estamos todos juntos aqui para conversar e ver como podemos fazer".

A partir daí, ocorreram várias reuniões para as quais o Vitae Civilis foi convidado, tendo participado de todas. O papel do Vitae Civilis foi dar apoio e orientação ao grupo em questões institucionais, conceituais e administrativas. O Vitae Civilis elaborou o estatuto, com base nos pontos levantados pelos próprios extratores e produtores, organizou toda a documentação necessária e orientou o grupo sobre como proceder para legalizar a associação.

Em 18 de setembro de 1994, no bairro do Arapongal, no Município de Registro, ocorreu a assembléia de fundação da Associação de Extratores e Produtores de Plantas Aromáticas e Medicinais do Vale do Ribeira, que definiu em seu estatuto, legalizado juridicamente, as seguintes finalidades:

a. Congregar os extratores, produtores e comerciantes ligados à produção de plantas aromáticas e medicinais, tanto cultivadas como nativas, da região do Vale do Ribeira.

b. Buscar padrões de produção, extração e comercialização de espécies selecionadas, aromáticas e medicinais, tanto cultivadas como nativas, criando normas individuais para cada espécie, em entidades de classe interessadas e outras organizações pertinentes.

c. Incentivar, na região, a adoção de práticas conservacionistas, promovendo a preservação de recursos naturais, notadamente por meio da implantação, recuperação e condução de florestas. 
d. Incentivar práticas de controle de qualidade do material extraído, produzido e comercializado, conforme normas preestabelecidas.

e. Incentivar, pelo uso de tecnologias adequadas, práticas de manejo florestal e controle para evitar e minimizar o processo de erosão do solo, visando o controle do assoreamento dos cursos d'água responsáveis pela drenagem das águas pluviais.

f. Colaborar para manutenção na região, a médio e longo prazo, dos ecossistemas florestais que garantem o suprimento de plantas aromáticas e medicinais, matériaprima para estudos e utilização pela Aepam e pela população.

g. Colaborar com estudos, execução e controle de reposição florestal, com a participação de proprietários rurais, posseiros e arrendatários da região, oferecendolhes opção de renda alternativa, principalmente com o aproveitamento racional de áreas não adequadas para outras finalidades produtivas.

h. Manter intercâmbio com entidades e outras associações ligadas à área.

i. Firmar protocolos de intenção e convênios com órgãos públicos envolvidos, direta ou indiretamente, com a atividade florestal, no sentido de que possam ser eficazmente atendidos, na região, os imperativos legais para conservação, preservação e reposição de florestas.

j. Firmar acordos e contratos com entidades públicas e entidades de direito privado interessadas na implantação, preservação, proteção, reposição, recuperação e condução de florestas, sobre assuntos relativos às atividades da Aepam.

k. Promover, juntamente com órgãos governamentais do setor, plantio, recuperação e condução de espécies medicinais e aromáticas nativas e introduzidas.

As reuniões continuaram ocorrendo após a fundação da Aepam. Alguns representantes do Ibama e do DEPRN, que participavam dos encontros, com o apoio dos extratores, produtores e comerciantes de plantas medicinais, solicitaram ao Vitae Civilis o desenvolvimento de estudos para obter dados e parâmetros científicos, à luz da ciência ocidental, para o manejo sustentável de espécies medicinais.

Os motivos que mobilizaram os representantes dos órgãos governamentais foram a ilegalidade da extração e da comercialização de plantas medicinais em decorrência da completa ausência de parâmetros alicerçados em dados obtidos por meio de métodos da ciência ocidental, bem como a falta de instrumentos legais para controlar a extração comercial de plantas medicinais na Mata Atlântica. Sem esses parâmetros científicos, o 
Ibama e o DEPRN estariam impossibilitados de exercer eficazmente suas funções de fiscalização e orientação desse extrativismo, conforme dispõe o Decreto Federal no $^{0}$ $750 / 93$.

O Vitae Civilis continuou apoiando a Aepam desde sua fundação oficial. Esse apoio do Vitae Civilis procurou sempre atender reivindicações da associação e procurou também oferecer orientações para seu fortalecimento. Estas orientações e ações do Vitae Civilis incluíram a elaboração de vários documentos, como projetos e planos, assim como mobilização das mulheres para que estas participassem ativamente da associação.

O Vitae Civilis, em contrapartida, vem recebendo apoio da Aepam, mais especificamente do Sr. Carlos Alberto Novi. Seu apoio tem sido importante, especialmente no que diz respeito a estudos de plantas medicinais, identificação $\mathrm{e}$ seleção de comunidades rurais para realização de trabalhos de apoio ao fortalecimento dessas comunidades.

Foi dessa maneira que surgiu o projeto Da mata à casa: sustentabilidade do uso de plantas medicinais da Mata Atlântica (Vale do Ribeira, SP), valendo-se também da experiência obtida nos trabalhos realizados junto às comunidades tradicionais da Estação ecológica de Juréia-Itatins (BORN et al., 1996; BORN, 1998).

\subsection{O projeto Da mata à casa}

O projeto Da mata à casa objetiva estimular o manejo sustentável, o cultivo e a comercialização de plantas medicinais da Mata Atlântica, na região do Vale do Ribeira, como um dos instrumentos para a busca da sustentabilidade do desenvolvimento dessa região. Esse projeto está sendo realizado nos municípios de Registro, Eldorado, Sete Barras, Juquiá, Pariquera-açu, Iguape e Cananéia, na região do Vale do Ribeira do Estado de São Paulo.

O projeto Da mata á casa teve início em 1993, quando foram iniciados os trabalhos de apoio à mobilização e ao fortalecimento dos extratores e produtores de plantas medicinais e aromáticas da referida região do Estado de São Paulo. Tal apoio resultou na criação da Aepam, conforme foi descrito no item 2.2.

Conforme foi dito anteriormente, nas reuniões da Aepam, representantes dessa 
Associação e de órgãos do governo solicitaram ao Vitae Civilis a realização de estudos para obter indicadores científicos, à luz da ciência ocidental, para a exploração sustentada de espécies medicinais que ocorrem espontaneamente na Mata Atlântica. Essa solicitação foi mais um fator de incentivo para a elaboração do projeto Da mata à casa. A experiência adquirida no projeto Juréia-Itatins e a premissa de que é possível se valer da exploração e da comercialização sustentáveis de recursos naturais para se conseguir a conservação da Mata Atlântica e a sustentabilidade do desenvolvimento na região do Vale do Ribeira foram cruciais na idealização do projeto Da mata à casa. Com isso em mente, idealizei e estruturei o projeto, com base na abordagem metodológica de resgatar e entender as técnicas e a lógica usadas pelos extratores e produtores de plantas medicinais para obtenção do material vegetal, beneficiamento e comercialização. Além do diagnóstico etnobotânico, a abordagem da pesquisa e das ações apoiou-se também no conhecimento e na compreensão, de maneira geral, das condições de vida e percepções desse grupo quanto à conservação da Mata Atlântica e ao desenvolvimento da região do Vale do Ribeira.

A proposta, portanto, foi realizar um amplo diagnóstico etnobotânico, além de estudar aspectos sociais, econômicos e ambientais. Aspectos da relação do grupo de extratores e produtores de plantas medicinais com a conservação da Mata Atlântica e com os órgãos governamentais envolvidos, direta ou indiretamente, com a exploração e comercialização de plantas medicinais da região do Vale do Ribeira também eram objeto de estudo.

Os dados levantados nesses diagnósticos seriam usados para realizar pesquisas em manejo sustentável de espécies medicinais. Tais dados e a experiência obtidos seriam utilizados para realizar ações visando a capacitação e o treinamento do grupo de extratores e produtores de plantas medicinais, de proprietários das áreas onde esse projeto está sendo realizado, de comunidades rurais e de agricultores. Além disso, os dados dos estudos e dos diagnósticos serviriam também para acompanhar políticas ambientais e públicas que dizem respeito à sustentabilidade do desenvolvimento e do uso de plantas medicinais na região, bem como para delas participar. 


\section{MARCOS CONCEITUAIS E CONTEXTUAIS}

Serão apresentados, brevemente, conceitos e contextos dos três seguintes temas abordados nesta tese: sustentabilidade do desenvolvimento, pesquisa etnobotânica e plantas medicinais.

No capítulo sobre a sustentabilidade do desenvolvimento, serão abordados, resumidamente, alguns dos momentos que mais marcaram na mudança desse paradigma; alguns dos principais conceitos e algumas estratégias para a busca da sustentabilidade, como complementação do que foi apresentado no item 1.- Introdução.

No capítulo de pesquisa etnobotânica, serão abordados diversos conceitos, utilizados como uma das estratégias para a busca da sustentabilidade. Isso decorre de sua importância nas diferentes dimensões da sustentabilidade do desenvolvimento. Também serão feitas reflexões sobre a metodologia e as abordagens usadas, tomando como exemplos os levantamentos realizados em área rural, onde se encontram remanescentes de Mata Atlântica (Estação ecológica de Juréia-Itatins), e em área urbana, em um dos bairros da cidade de São Paulo (São Miguel Paulista).

No que diz respeito ao último tema — plantas medicinais -, serão abordadas brevemente questões sobre o manejo sustentável de plantas medicinais da Mata Atlântica, sobre aspectos do mercado de plantas medicinais, especialmente o da região metropolitana da cidade de São Paulo e, finalmente, serão apresentados, resumidamente, os principais atos normativos que tratam do direito de propriedade intelectual de comunidades tradicionais e locais; do uso de fitoterápicos e do acesso, da exploração e da comercialização de plantas medicinais da Mata Atlântica.

\subsection{Sustentabilidade do desenvolvimento}

Desde o Encontro de Founex, em junho de 1971, parte do processo de preparação da Conferência das Nações Unidas sobre o Ambiente Humano (realizada em Estocolmo, em 1972), tem sido percorrido um longo caminho para analisar e praticar a relação intensa e circular entre meio ambiente e desenvolvimento (BORN, 1998a). O Relatório de Founex identificou, abordou e rejeitou as abordagens do economicismo e 
do ecologismo e traçou um caminho intermediário e eqüidistante entre essas posições extremas. De um lado estava o ecologismo dizendo que "o mundo estava superpovoado e portanto condenado ao desastre, seja pela exaustão dos recursos naturais esgotáveis seja pela excessiva sobrecarga de poluentes aos sistemas de sustentação da vida". De outro lado, estava o ecomomicismo que diziam que "a capacidade fisica $e$ as conseqüências deletérias do lançamento de dejetos na biosfera por meio de 'ajuste ecológico', deixando de perceber os limites da substituição do capital 'natural' pelo capital construido pelo homem' " (SACHS, 1993).

O Relatório de Founex, a Declaração de Estocolmo-72 e a Declaração de Cocoyoc $^{3}$ continham uma mensagem de esperança com respeito ao planejamento e à implementação de estratégias ambientalmente viáveis para promover um desenvolvimento socioeconomico eqüitativo, conhecido no início como ecodesenvolvimento (SACHS, 1993).

Em 1980, a IUCN, o PNUMA e a WWF lançaram a Estratégia Mundial para a Conservação, publicada no documento intitulado Cuidando do Planeta Terra: Uma Estratégia para o Futuro da Vida (IUCN, PNUMA \& WWF, 1992). Neste estudo foi introduzido o termo "desenvolvimento sustentável", que enfatiza a interdependência de conservação e desenvolvimento. Destacam-se ainda nesse estudo: o conceito de desenvolvimento e os princípios ou diretrizes básicas para a conservação e o uso sustentável dos ecossistemas.

Em 1983, criou-se a Comissão Mundial sobre Meio Ambiente, como resultado da constatação da não implementação do Programa de Ações e da Declaração sobre Ambiente Humano (Declaração de Estocolmo-72). Esta Comissão, liderada pela Ministra da Noruega, Dra. Brundtland, realizou uma longa série de audiências públicas em diversos paises, procurando engajar órgãos governamentais, não-governamentais, cientistas, populações indígenas, tradicionais e locais nos debates sobre estilos alternativos de desenvolvimento. Essas audiências resultaram, em 1987, no Relatório

${ }^{3}$ A Declaração de Cocoyoc foi resultante do Simpósio do Programa das Nações Unidas para o Desenvolvimento ( PNUMA) e da Conferência das Nações Unidas sobre Comércio e Desenvolvimento, realizada no México em 1974. (SACHS, 1993). 
Nosso Futuro Comum, que já convocava para a Conferência das Nações Unidas sobre Meio Ambiente e Desenvolvimento, a Rio-92 (BORN, 1998a).

Houve vários encontros internacionais, realizados em diferentes países do mundo, com a participação de representantes de governos, empresas privadas, mídia, organizações de classe, ONGs, cientistas, populações indígenas, tradicionais e locais, nos quais se debateu intensa, exaustiva e "calorosamente" a formulação básica de desenvolvimento sustentável (BORN, 1998). Essa definição de desenvolvimento foi apresentada, em 1987, pela Comissão Brundtland como sendo: "o desenvolvimento que atende às necessidades básicas das gerações atuais sem comprometer a capacidade das gerações futuras atenderem às suas, observados os limites e capacidades dos processos ambientais" (COMISSÃO MUNDIAL SOBRE MEIO AMBIENTE E DESENVOLVIMENTO, 1988).

Em 1992, é realizada a Conferência das Nações Unidas sobre Meio Ambiente e Desenvolvimento (CNUMAD-92), que reuniu cerca de 180 países, 105 chefes de Estado, na cidade do Rio de Janeiro. Esta Conferência, conhecida também como Rio-92, disseminou a discussão e identificou as ações (Agenda 21) para viabilizar o desenvolvimento sustentável em todo o mundo (BORN, 1998a). Entre essas ações, destacam-se as seguintes, segundo SACHS (1993) e BORN (1998a):

a. a institucionalização da preocupação com a gestão ambiental;

b. a adoção e a implementação da Convenção de Mudanças de Clima, da Convenção de Diversidade Biológica e da Agenda 21;

c. a conscientização crescente da opinião pública e a pressão dos movimentos civis e dos partidos verdes, assim como a emergência da sociedade civil na cena política como uma força social incipiente para influenciar os Estados e o poder econômico;

d. reconhecimento da democracia participativa em todos os níveis: local, nacional e global;

e. os debates sobre o abismo existente entre os países industrializados e o resto do mundo.

Ocorreram longas, intensas e exaustivas negociações, tanto no processo preparatório, durante a realização da CNUMAD-92, como após a realização dessa Conferência, sobre o conceito de sustentabilidade do desenvolvimento, na busca de 
estratégias para atingi-lo. Tais negociações ocorreram entre grupos com ideologias, tendências políticas e interesses diferentes. Essas diferenças determinaram as bases para a abordagem que cada grupo apresentava para as discussões e negociações, objetivando a elaboração desse conceito e das estratégias para atingi-lo (BORN, 1998a).

Apesar das divergências encontradas, pode-se, no entanto, verificar tendências convergentes no que diz respeito à base de concepção da sustentabilidade. Nesse caso, vários autores concordam que a sustentabilidade do desenvolvimento pode ser atingida pelo equilibrio em cada dimensão que faz parte do desenvolvimento sustentável, e entre elas. Esse equilíbrio também deve ocorrer nas esferas local, regional, nacional e internacional, e ser durável, ou seja que tanto a geração presente como também as futuras se beneficiem dos esforços de desenvolvimento sem que haja comprometimento da capacidade de sobrevivência de todos os seres vivos (SACHS, 1993; BRÜSEKE, 1995; STAHEL, 1995; BORN, 1998a).

A sustentabilidade do desenvolvimento engloba a prosperidade dos indivíduos e das comunidades, o desenvolvimento das culturas humanas, a continuidade da vida humana, a obediência dos seres humanos aos limites da natureza de forma a não destruir a diversidade, a complexidade e a função do sistema ecológico. É importante que isso aconteça com a tomada de consciência dos seres humanos por causa da necessidade de se ter um mundo melhor, e isso, por sua vez, deve ser adquirido por meio de mudanças de hábitos antigos $\mathrm{e}$ da internalização dos novos hábitos necessários. Esse desenvolvimento, portanto, demandará longo tempo para ocorrer e demonstrar sua capacidade de perdurar (SACHS, 1993; MAGALHÃES, 1995).

Segundo GUIMARÃES \& MAIA (1997), a sustentabilidade do desenvolvimento depende das relações entre os seguintes componentes principais de determinado agrupamento humano:

População (tamanho e densidade demográfica);

Organização social (padrões de produção e estratificação social);

Entorno (hábitat fisico e construído, bem como processos ambientais);

Tecnologia (progresso técnico e formas de utilização da energia);

Aspirações sociais (padrões de consumo e valores sociais).

Esses autores (op. cit.) ressaltaram que o nível de bem-estar de uma comunidade 
depende de seu meio ambiente imediato, porém, cada vez mais, ele depende do meio ambiente não imediato.

Há dezenas de definições sobre desenvolvimento sustentável. Há também divergências entre os autores consultados no que se refere à quantidade e à definição das dimensões envolvidas no desenvolvimento sustentável. Serão apresentados, a seguir, oito dimensões ou sustentabilidades parciais com suas respectivas definições, segundo GUIMARÃES \& MAIA (1997) e SACHS (1998):

1. Sustentabilidade social: é a capacidade de incorporar as populações marginalizadas no processo de desenvolvimento para promover a eqüidade social; é considerada, por alguns, a dimensão mais importante (MAGALHÃES,1995; BORN, 1998a; SACHS, 1998);

2. Sustentabilidade cultural: é a capacidade de proteção dos valores que asseguram a identidade cultural de um povo e, ao mesmo tempo, permitir a introdução dos novos valores necessários para dar suporte às transformações sociais e econômicas; nesse caso, cultura é entendida como a interface entre as sociedades humanas e a natureza. Desta forma os objetivos do desenvolvimento são definidos a partir de uma matriz cultural (MAGALHÃES, 1995; GUIMARÃES \& MAIA, 1997; SACHS, 1998);

3. Sustentabilidade ambiental: é a capacidade que a natureza tem de absorver e se recuperar das ações antrópicas, ou seja, mesmo submetida a ações antrópicas, a natureza mantém seu "capital natural", que engloba tanto as taxas de recomposição (para os recursos naturais) como as taxas de regeneração (para os ecossistemas) (GUIMARÃES \& MAIA, 1997);

4. Sustentabilidade ecológica: é a capacidade produtiva da base física e objetiva a conservação e o uso do estoque de recursos naturais incorporados às atividades produtivas; no caso dos recursos naturais renováveis, a taxa de uso deve ser equivalente à taxa de recomposição do recurso (SACHS, 1993; MAGALHÃES, 1995; GUIMARÃES \& MAIA, 1997);

5. Sustentabilidade econômica: é a capacidade de manutenção econômica dos empreendimentos (MAGALHÃES,1995); ela é fundamental, mesmo sendo meramente um instrumento para o desenvolvimento (BORN, 1998a);

6. Sustentabilidade política: é a apropriação efetiva de todos os direitos e o exercício efetivo da cidadania; ela proporciona o desenvolvimento dentro de uma democracia 
plena e compreende a sustentabilidade política em nível de Estados e nações (GUIMARÃES \& MAIA, 1997; SACHS, 1998);

7. Sustentabilidade demográfica: é a capacidade de suporte da natureza, que engloba a sustentabilidade ecológica e a ambiental (GUIMARÃES \& MAIA, 1997);

8. Sustentabilidade política internacional: trata da construção de um sistema internacional capaz de assegurar efetivamente a paz e o desenvolvimento, na socioesfera, e a integridade na biosfera (SACHS, 1998).

Duas características são inerentes à idéia de sustentabilidade nas oito dimensões apresentadas: a visão de longo prazo e a participação da sociedade (MAGALHÃES, 1995). Além disso, pode-se acrescentar a essas duas características a visão e as ações a curto e médio prazos, que fazem parte do processo de desenvolvimento sustentável como um meio para se atingir sociedades sustentáveis.(ver 1 - Introdução).

Não há dúvida de que todos aqueles que saibam algum conceito de desenvolvimento sustentável, sejam favoráveis e desejem a sustentabilidade do desenvolvimento. Porém, há uma distância muito grande entre esse desejo e o que realmente vem ocorrendo. A falta de expectativa de melhora a curto e médio prazo também é bastante desanimadora. Infelizmente, o que temos hoje é um desenvolvimento insustentável (SACHS 1993; SACHS, 1998).

Isso ocorre por várias razões, mas a falta de metodologia disponível para o planejamento do desenvolvimento e, principalmente, a falta de uma nova ética com base em valores de respeito entre e inter as sociedades podem ser enfatizadas (BORN, 1998a).

Para a consecução da sustentabilidade são necessárias várias mudanças de atitudes e de paradigmas, pessoais e coletivos. Além disso, entre os autores consultados, parece haver concordância de que há a necessidade:

- de mudança de padrão de consumo, ou seja, de conter o consumo excessivo dos países industrializados e das minorias ricas das sociedades (GUIMARÃES \& MAIA, 1997);

- da eliminação das desigualdades sociais e econômicas.

- de se compreender que os sistemas econômicos dependem dos sistemas ecológicos, ou seja, há complementaridade entre o capital natural e o capital "construído pelo homem" (SACHS, 1993); 
- do avanço das pesquisas interdisciplinares sobre diversidade biológica e cultural, orientadas para a ação;

- de mudança da relação de poder entre os países industrializados e os em fase de industrialização;

- da tomada de consciência individual e coletiva da importância de se mudar o paradigma de desenvolvimento baseado exclusivamente no crescimento econômico;

- da aceitação do preço necessário para conservar e proteger a diversidade biológica e cultural;

- do envolvimento de todos os setores: (do governo, da sociedade civil, de organizações não-governamentais, de sindicatos, acadêmicos, privados, da mídia, entre outros);

- da redução da emissão de contaminantes e do uso de recursos naturais;

- de política ambiental acordada com a sociedade civil;

- de mudança da administração pública e das empresas privadas;

- do conhecimento da diversidade biológica e cultural de forma a poder gerar abordagem e tecnologia compatíveis com o processo de desenvolvimento sustentável.

Para se atingir a sustentabilidade do desenvolvimento é necessário um longo tempo. Os economistas que trabalham com esse novo paradigma de desenvolvimento, que engloba questões sociais em seu planejamento e em suas ações, são obrigados pela natureza a trabalhar com escalas temporais e espaciais muito diferentes daquelas a que estão acostumados e para as quais estão desaparelhados (SACHS,1998).

As premissas fundamentais das estratégias de transição do desenvolvimento insustentável para o sustentável incluem as escalas temporais e espaciais (englobam reaparelhamento das indústrias, mudanças culturais, consciência da falta de linearidade nas estratégias para executar planejamentos, entre outros); custos da transição e ajuste técnico (os países industrializados devem arcar com os maiores custos); parcerias entre o Estado, as empresas, o terceiro setor (ONGs), a academia etc. "A eficiência das estratégias de transição dependerá do grau de audácia das mudanças institucionais, da capacidade de conceber pacotes multidimensionais de politicas públicas e da competência para redirecionar o progresso técnico." (SACHS, 1993). 
A principal ferramenta que a sociedade civil tem para procurar a sustentabilidade do desenvolvimento é a organização comunitária, com participação democrática e equiitativa de todos, de maneira a construir a entidade de classe que a represente juridicamente como parte de um plano orientado para ação, com base em princípios éticos e no paradigma do desenvolvimento sustentável. Como exemplo, disso na região do Vale do Ribeira, o Vitae Civilis facilitou, mobilizou e catalisou a construção das seguintes Agendas 21:

a. Primeira proposta de Agenda 21 de uma Bacia Hidrográfica do Brasil, denominada Plataforma Ambiental Minima para o Desenvolvimento Sustentável do Vale do Ribeira. Ela foi elaborada por representantes de instituições do terceiro setor, que atuam na região do Vale do Ribeira, e por representantes de comunidades da região (VITAE CIVILIS, 1995a);

b. Primeira Agenda 21 elaborada por uma comunidade rural da região do Vale do Ribeira, denominada Agenda 21 do Bairro Guapiruvu (Vale do Ribeira, SP.) (VITAE CIVILIS \& AGUA, 1998).

\subsection{A pesquisa etnobotânica}

Dentre as etnociências, encontram-se a etnobotânica e a etnofarmacologia ${ }^{4}$.

A primeira vez em que o termo etnobotânica foi mencionado na literatura científica foi em 1896. O botânico americano, John W. Harshberger, publicou seu trabalho The Purposes of Ethnobotany, que tratou das plantas usadas por povos aborígines (BALICK \& COX, 1997; JAIN, 1987; SAKLANI \& JAIN, 1994).

Segundo BALICK \& COX, (1997), Linnaeus, botânico famoso pela elaboração

4 Segundo HOLMESTRED \& BRUHN (1982:252 apud ELISABETSKY, 1986): "Etnofarmacologia é a exploração cientifica interdisciplinar dos agentes biologicamente ativos, tradicionalmente empregados ou observados pelo homem.". Entre os vários pesquisadores, há o uso dos termos etnobotânica e etnofarmacologia para se referir aos estudos do conhecimento tradicional sobre o uso de material vegetal, inclusive de plantas medicinais. 
do sistema de classificação vegetal e animal mais usado na ciência moderna, realizou trabalhos etnobotânicos.

Dois séculos após Linnaeus, surgiu o pesquisador americano, Richard Evans Schultes, muito admirado por cientistas do mundo, principalmente pelos americanos. Ele realizou, desde 1937, amplos levantamentos florísticos associados ao uso que povos indígenas da Amazônia, e também de outras partes do mundo, davam às plantas (BALICK \& COX,1997).

Depois disso, a etnobotânica teve grande avanço, ampliando e aprofundando cada vez mais seu uso nos últimos anos, quando foi percebida a possibilidade de ela ser usada como estratégia para a descoberta de novas drogas por cientistas, pelo governo e por empresas americanas. Nos últimos 20 anos, vem se desenvolvendo vertiginosamente e agora se tornou reconhecida como disciplina científica (ALEXIADES, 1996).

A etnobotânica objetiva entender a ligação entre conhecimento, cognição e comportamento nas interações entre os seres humanos e seu meio ambiente. Além disso, busca entender como outros povos vêem o mundo e como é sua relação com ele. A maneira como os povos incorporam as plantas em suas tradições culturais, religiosas e cosmológicas revelam muito sobre os próprios povos (POSEY, 1986; TOLEDO, 1992).

Apesar da definição acima, há vários conceitos para a etnobotânica que diferem entre si, revelando a falta de consenso e de clareza nas abordagens e na metodologia, que podem ser usadas pelos cientistas e comunicadores sociais.

Entre os conceitos de etnobotânica, há aqueles bem amplos e os restritivos. Segundo MARTIN (1995), a etnobotânica é a parte da etnoecologia que se preocupa com as plantas. A etnoecologia para esse autor é amplamente usada para englobar todos os estudos que descrevem a interação dos povos locais com o ambiente natural. Inclui disciplinas como etnobiologia, etnobotânica, etnoentomologia e etnozoologia.

Para ALEXIADES (1996), a etnobotânica inclui o estudo de todas as sociedades humanas, no passado e no presente, e os tipos de inter-relações (ecológica, evolucionista e simbólica) entre essas sociedades e o meio ambiente.

Dentre os trabalhos de etnobotânica conhecidos, há a predominância de duas abordagens. Uma é a abordagem econômica e a outra é a cognitiva. A primeira focaliza o modo como os povos utilizam as plantas e a segunda refere-se como os povos as vêem e as classificam (ALEXIADES, 1996). 
Há, ainda, uma terceira abordagem que procura conciliar esses dois tipos de etnobotânica, ou seja, refere-se tanto à utilização pragmática das plantas por sociedades humanas, passadas e presentes, como ao simbolismo dessa interação (BORN, 1998).

Outro aspecto a ser considerado é o representado pelas várias facetas, dimensões, e pela interdisplinaridade da etnobotânica (MARTIN, 1995; ALEXIADES, 1996; BALICK \& COX, 1997).

A faceta interdisciplinar da etnobotânica é consenso entre os pesquisadores e foi tomada como base para o desenvolvimento do presente trabalho, visto que ele faz parte de um projeto maior (ver 2.3 - O projeto Da mata à casa). A etnobotânica engloba muitos campos, como por exemplo os campos da botânica, bioquímica, farmacologia, toxicologia, medicina, nutrição, agricultura, ecologia, evolução, religião, sociologia, antropologia, lingüística, psicologia, do folclore, da história (ALEXIADES, 1996; BALICK \& COX, 1997), que precisam ser inter-relacionados. É reconhecido, por alguns, que a interdisciplinaridade é um desafio para os profissionais e para as instituições. Para haver interdisciplinaridade é necessário que haja cooperação entre diferentes profissionais de modo que se favoreça a comunicação entre eles.

Provavelmente, o maior desafio da interdisciplinaridade está na mudança do paradigma do saber específico. É necessário que haja "abertura" dos profissionais para aceitar e entender as outras áreas. Outro grande desafio é a falta de treinamento interdisciplinar nas instituições de ensino e de pesquisa (BORN, 1998).

O trabalho, ora apresentado, apoiou-se na abordagem e no conceito mais amplo da etnobotânica. Para tanto, foi tomado como princípio que a etnobotânica serve como um ponto de partida útil para a compreensão das interações, associações e inter-relações entre as sociedades humanas, atuais e passadas, e o meio ambiente.

Outra abordagem desse trabalho, é que os seres humanos se inter-relacionam com outros da mesma espécie, não só como indivíduos, mas também como membros de grupos sociais. Seja como indivíduo seja como membro de grupos sociais, o ser humano se inter-relaciona também com as forças externas à sua comunidade. Mesmo que se aceite o indivíduo como a unidade fundamental de adaptação, não há dúvida de que a espécie humana depende de suas unidades sociais e de outros seres vivos para garantir sua sobrevivência e sua satisfação.

O conhecimento adquirido pelos seres humanos é passado de geração a geração e sua aceitação varia entre os individuos de um mesmo grupo social. Tal conhecimento 
ocorre no grupo social em estado de experimentação permanente em relação aos limites das regras culturais, dos comportamentos aceitos do balanço custo-benefício dessa experimentação (MORAN, 1991).

Um outro objetivo da etnobotânica é estudar, portanto, a relação entre as sociedades humanas, seus indivíduos e a natureza, especialmente os vegetais. Essa relação pode ser concreta ou abstrata. Ela é concreta quando os seres humanos se relacionam com as riquezas da natureza que podem ser vistas, tocadas, apalpadas etc. A "abstrata" é aquela que os nativos, ou seja, as pessoas que nasceram e se criaram em áreas de florestas, podem sentir e que alguns, segundo eles, podem ver. Foi colocado a palavra abstrata entre aspas porque essa relação é abstrata para as pessoas que vivem na cidade, mas, no imaginário dos nativos, ela não é abstrata, é concreta (BORN \& RODRIGUES, 1998).

A etnobotânica tem várias funções, dentre as quais, podem ser citadas (SVENDSEN \& SCHEFFER, 1982; ELISABETSKY, 1986; ELISABETSKY \& SHANLEY, 1994; BORN et al., 1996):

- levantamento e análise de métodos tradicionais empregados por grupos humanos para utilização do material vegetal na construção de suas casas, seus meios de transporte, seus remédios, entre outros (ALEXIADES, 1996);

- observação de como os diversos grupos humanos se relacionam com o ambiente, seu modo de ver, de pensar, de considerar e de usar a natureza, produzindo meios de subsistência; observação da forma como se apropriam ideologicamente da natureza, para construir representações simbólicas relevantes para a sua organização social (BORN et al., 1989; AMOROZO, 1996);

- levantamento e análise de métodos tradicionais empregados por grupos humanos para usar material vegetal para obtenção de renda por meio de sua exploração e comercialização; levantamento de como é a relação do grupo com a natureza (CUNNINGHAM, 1996);

- estímulo para apoiar e facilitar a mobilização de grupos humanos para a busca de melhoria de condições de vida no sentido da sustentabilidade do desenvolvimento comunitário (BORN et al., 1996; BORN, 1998);

- fornecimento de contribuições para a elaboração de planos de manejo de áreas ambientalmente protegidas e habitadas por populações humanas há várias gerações 
(RODRIGUES, 1998);

- proteção da diversidade biológica e cultural (POSEY, 1986);

- descoberta de novas drogas (descoberta de droga-protótipo; fonte de matéria prima para medicamentos semi-sintéticos; reconhecimento de ações terapêuticas não atribuídas a compostos conhecidos, ou seja, já utilizados para outros fins) (ELIZABETSKY, 1986);

- integração do sistema oficial de saúde com o popular/tradicional;

- aproveitamento da planta in natura para desenvolver preparações farmacêuticas a partir das informações etnobotânicas, fazendo testes de eficácia e de toxicidade das preparações populares e, se possível, determinando os princípios ativos dessas preparações populares (ELIZABETSKY, 1986);

- aproveitamento comercial de extratos simples de plantas medicinais;

- valorização do conhecimento tradicional e empírico, desenvolvendo o respeito por ele;

- conhecimento de novos conceitos de modos de vida;

- instrumento para a mobilização de grupos para a busca de melhores condições de vida.

No que se refere ao uso da etnobotânica como estratégia para a busca da sustentabilidade do desenvolvimento, esta etnociência pode ser usada em pesquisa orientada para a ação de apoiar e facilitar a mobilização de comunidades locais e tradicionais que desejam ter melhores condições de vida em um sentido que inclua a sustentabilidade do desenvolvimento comunitário (BORN et al., 1996; BORN, 1998). Essa função da etnobotânica foi demonstrada no projeto Juréia-Itatins (ver 2.1 - O Vitae Civilis), quando BORN et al (1996) realizaram a pesquisa em etnobotânica como instrumento para a mobilização das comunidades da Cachoeira do Guilherme e do Aguapeú da Estação ecológica de Juréia-Itatins, objetivando viabilizar o atendimento a duas reivindicações prioritárias dessas comunidades: mais opções de obtenção de renda e melhor atendimento à saúde.

A etnobotânica pode fornecer informações importantíssimas para a elaboração de planos de manejo de áreas ambientalmente protegidas e habitadas por populações humanas há várias gerações (RODRIGUES, 1998a). Do ponto de vista do planejamento da conservação ambiental, voltado para a sustentabilidade do desenvolvimento, a 
combinação dos conhecimentos tradicional e o científico, à luz da ciência ocidental, na formulação de estudos interdisciplinares possibilita enfrentar o grande desafio das análises sistêmicas requeridas para o planejamento ambiental. As análises sistêmicas são dificultadas, em grande parte, pela fragmentação do saber derivada da especialização dos conhecimentos (BORN, 1998).

O mundo moderno, mais especificamente o científico, conhece muito pouco sobre as diversidade biológica, genética, ecológica e cultural existentes em todos os biomas do Planeta Terra, principalmente nos das florestas tropicais. Este desconhecimento se refere tanto ao inventário da diversidade como ao seu funcionamento, ao seu patrimônio genético, às relações entre as espécies etc.. Há um consenso entre os estudiosos de que as riquezas das florestas tropicais são grandes e quase inexploradas pela ciência ocidental (MYERS, 1992; PRINCIPE, 1991; BRASIL/ MINISTÉRIO DO MEIO AMBIENTE, DOS RECURSOS HÍDRICOS E DA AMAZÔNIA LEGAL, 1998).

Agindo sistemicamente, as comunidades tradicionais e locais, que vivem no meio rural, interagindo, associando-se e relacionando-se com o meio natural, mantêm conhecimentos importantes sobre espécies e componentes do espaço fisico. Essas comunidades sabem identificar componentes da flora e da fauna por meio de um sistema de classificação próprio (LÉVI-STRAUSS, 1989).

Por exemplo, as comunidades tradicionais da Estação ecológica de Juréia-Itatins e, principalmente o seu terapeuta e líder religioso e político, Sr. Sátiro Tavares da Silva, escolhem as plantas medicinais para elaborar os fitoterápicos de acordo com o órgão enfermo. Contra os problemas do figado usam folhas amargas e com a morfologia semelhante à do figado. Além disso, eles também têm um sistema de selecionar a planta e o órgão ao qual ela corresponde com base no conceito de plantas "frescas", "quentes" e "internadas" (esta indica uma planta ou órgão vegetal nem quente nem fresco). Ainda, segundo BORN et. al. (1989), as plantas não apresentam nenhum aspecto indicador, seja na morfologia seja no aroma seja no sabor, a respeito da sua considerada pontencialidade "quente", "fresca", ou "internada". De maneira geral, as plantas medicinais consideradas como "frescas" são usadas contra os problemas de saúde considerados "quentes" (como, ferida, machucaduras interna e externa, febre, catarata, dor de cabeça, pernas bambas, tontura, disenteria, dor de dente, gripe) e as "quentes" são usadas contra problemas de saúde considerados "frescos". Segundo as comunidades 
e seu líder, o surgimento dos problemas de saúde considerados "frescos" ocorre em conseqüência de "friagem", correntes de vento frio, etc. que são, por exemplo, tosse com ou sem catarro, menstruação atrasada, barriga empanturrada, cólica de mulher (cólicas menstruais), cólicas de bebê (cólicas infantis), dor de barriga (cólicas abdominais), dor de garganta com rouquidão, nervoso (irritação, aperto no peito), reumatismo, figado, coceira de mulher (coceira com corrimento vaginal), lombrigueira.

$\mathrm{O}$ conhecimento tradicional apresentado anteriormente e vários outros encontrados entre os diversos grupos tradicionais justificam que na entrada do terceiro milênio da era cristã, vários cientistas reconhecem que o conhecimento das comunidades tradicionais e locais tem importante papel na busca da sustentabilidade do desenvolvimento. Além disso, eles consideram que boa parte dos profissionais envolvidos, direta ou indiretamente, com a promoção da sustentabilidade do desenvolvimento tem papéis muito importantes na busca dessa sustentabilidade. Tais profissionais poderiam, por meio de esforços interdisciplinares, avaliar o conhecimento tradicional, tratando-o como uma ferramenta para estudos cientificos, à luz da ciência ocidental. Poderiam tentar conciliar o conhecimento tradicional com o científico, obter dados e repassá-los de modo que as comunidades detentoras do conhecimento tradicional, possam se beneficiar do uso de tais dados (BORN, 1998). Foi com esse propósito que o projeto Da mata à casa foi idealizado e está sendo realizado (ver 2.3 O projeto Da mata à casa).

Concordando com essa abordagem, ALTIERI \& MERRICK (1997) afirmaram que etnobotânicos e ecologistas poderiam orientar o uso da ciência agrícola moderna para o desenvolvimento da produtividade do pequeno produtor rural. Poderiam também fornecer informações críticas aos planejadores sobre os recursos que necessitam de proteção e sobre os fatores ecológicos e administrativos que determinam a persistência da vegetação natural nos agroecossistemas tradicionais.

Há consenso entre os estudiosos do final desse milênio sobre o fato de que uma das estratégias para a busca da sustentabilidade do desenvolvimento, além do extrativismo e da agricultura (entre outros), é o uso das pesquisas em etnociências orientadas para a ação. Isso significa que essas pesquisas podem ser usadas para fornecer dados tradicionais sobre as potencialidades do meio natural; para buscar as formas de garantir a manutenção dessas potencialidades e para instrumentalizar as comunidades locais e tradicionais, detentoras desse conhecimento valioso, para que elas 
possam ter melhores condições de vida, mantendo suas tradições (BORN, 1998).

Pode-se dizer que os pontos comuns entre esses conceitos são que os povos tradicionais interagem, observam, experimentam o mundo natural e a partir daí obtêm o conhecimento sobre ele. Por exemplo: segundo BORN et al. (1989), o Sr. Sátiro Tavares da Silva, por meio do conhecimento sobre os comportamentos dos animais, fazia previsões meteorológicas e, paralelamente, organizava seus afazeres, como pescar, plantar ou cuidar da roça, buscar lenha e outros. Além disso, esse terapeuta popular selecionava determinada planta a ser usada para o tratamento de um problema de saúde específico, com base na relação entre animais e plantas, como pode ser verificado no depoimento a seguir.

"A erva-de-lagarto é comida pelo lagarto depois que ele briga com uma cobra venenosa". (Sr. Sátiro Tavares da Silva).

A planta erva-de-lagarto (Aphelandra venosa Wassh. et Smith) é uma herbácea, com folhas dotadas de manchas brancas e muito usada pela população da Juréia-Itatins em fitoterápicos com banha de lagarto. Esse remédio é usado em um ritual que se inicia dentro do rio e é concluído no Centro Espírita, de preferência, na presença da cobra morta e pendurada com a cabeça para baixo (BORN et al., 1989).

A interação entre as comunidades da Juréia-Itatins e a natureza é mediada por crenças, que podem ser ampliadas para um plano totalmente espiritual para se obter conhecimentos sobre outras plantas medicinais. Conforme BORN et al. (1989) relatou em seu trabalho sobre o fato da utilização das plantas medicinais, que relata pelo Sr. Sátiro estar intrinsecamente relacionado com aspectos religiosos, como fé em Deus, rezas e benzeduras. Estava presente em suas preces a referência a bons e maus espíritos, pedindo sempre a aproximação dos primeiros e o afastamento dos segundos:

"Senhor Deus todo poderoso, enviai-nos bons espiritos para que a Luz ajude-nos a distinguir a verdade, para nos conduzirmos pela estrada verídica. Afastai de nós os maus espiritos, encarnados $e$ desencarnados, que conduzem os homens ao erro." (Sr. Sátiro Tavares da Silva). 
Para o Sr. Sátiro Tavares da Silva, segundo BORN et al. (1989), a aquisição de novos conhecimentos sobre plantas medicinais, por exemplo, era realizada por meio de seu "guia espiritual", que lhe "dizia" a composição das plantas, como fazer o novo remédio e como ministrá-lo ao paciente.

O conhecimento indígena, desenvolvido durante séculos de residência no local, pode fornecer informações preciosas sobre a conservação da diversidade biológica e genética bem como sobre a proteção da diversidade cultural. Isto se torna mais proeminente e urgente em uma economia em fase de globalização, em que as comunidades locais e tradicionais são bastante vulneráveis a mudanças rápidas da economia e da cultura. Entender os hábitos tradicionais, que incluem o uso de plantas, pode indicar estratégias para diminuir as conseqüências negativas dessas mudanças para as comunidades tradicionais (POSEY, 1986; BALICK \& COX, 1997).

Em relação, ainda, a importância da etnobotânica, tem sido verificado que a descoberta de novas drogas tem despertado o interesse do governo, de empresas e de cientistas de todos os países do mundo, mas principalmente dos Estados Unidos da América, que possuem vários programas visando a descoberta de novas drogas de espécies vegetais dos trópicos (ver 3.3 - Plantas medicinais).

As pesquisas com plantas medicinais têm sido consideradas muito úteis na descoberta de novas drogas (BRITO \& BRITO, 1993; PLOTKIN \& FAMOLARE, 1992). As substâncias consideradas como princípios ativos, isto é, que têm poder de curar ou de aliviar, são sintetizadas no metabolismo secundário. Essas substâncias, chamadas de metabólitos secundários podem fazer parte dos seguintes grupos de substâncias: alcalóides, glicosídeos, taninos, glicoalcalóides, látex, óleos essenciais, vitaminas, antiobióticos, elementos minerais etc. Os metabólitos secundários são usados pelas plantas para se adaptar a novas condições ambientais, para se proteger de fungos, bactérias, vírus, insetos e predadores herbívoros e também para ajudar em sua reprodução e dispersão.

A coleta de plantas e dados para a investigação da descoberta de novas drogas pode ser realizada por meio do uso das técnicas randômica, quimiotaxonomica e etnobotânica (ou etnofarmacológica). Tem sido reconhecido que o terceiro método - o etnofarmacológico - tem demonstrado ser o mais eficaz. Em Belize, apenas 6\% das espécies das coleções randômicas enviadas ao Instituto Nacional do Câncer dos Estados Unidos apresentaram eficácia, enquanto das espécies selecionadas com base na 
etnofarmacologia, 25\% mostraram atividades terapêuticas (BALICK, 1990 apud BALICK \& COX, 1997). O etnobotânico americano, Mickel Balick, verificou isso quando o referido instituto analisou amostras de 1500 espécies coletadas na América Latina e no Caribe. BALICK \& COX (1997) concluiram que a abordagem etnobotânica é a mais eficiente para analisar as 110000 espécies vegetais que se calcula que existam nos trópicos do Novo Mundo.

Para a descoberta de novas drogas, são usadas algumas sequiências de passos que William Withering usou para descobrir a digitalis (Digitalis purpurea), no século XVIII (BALICK \& COX, 1997). Foram isolados, dessa espécie, glicosídeos cardiogênicos. Essa seqüência já levou ao sucesso vários programas de etnobotânica de sociedades modernas, como a dos Estados Unidos da América, resultando na descoberta de novas drogas. Abaixo será apresentada, resumidamente, a sequiência mais usada pelos etnobotânicos:

1. Acúmulo de conhecimento tradicional de uma possível atividade terapêutica;

2. Observação do uso da planta por um curandeiro em seus pacientes;

3. Transmissão do conhecimento de um curandeiro a um cientista;

4. Coleta e identificação das plantas pelo cientista;

5. Teste de extratos da planta por meio de bioensaio pelo cientista (realização de screen preliminar para identificar atividades farmacológicas);

6. Isolamento de um composto puro por meio de bioensaio para fracionar a fonte de atividade em um extrato vegetal;

7. Determinação da estrutura da substância pura.

Com objetivo de obter drogas com melhores propriedades terapêuticas, químicas e físicas, tem-se modificado a estrutura química de compostos biologicamente ativos descobertos em plantas. Tem-se ainda sintetizado drogas a partir de compostos que ocorrem naturalmente nas plantas.

Como um exemplo do primeiro caso, temos a morfina (SVENDSEN \& SCHEFFER, 1982), isolada do fruto da Papaver somniferum, em 1803. Após a definição de sua estrutura química, em 1927-8, foi sintetizado um derivado da morfina chamado azidomorfina (6-deoxy-6-dihydroazidoisomorfina), que tem 300 vezes o efeito analgésico da morfina que o originou.

As plantas medicinais podem ser fonte de matéria-prima para medicamentos 
semi-sintéticos. Um dos exemplos são os hormônios sexuais. Estima-se que cerca de 95\% de todos os esteróides (hormônios esteroidais) foram produzidos pelo uso de sapogeninas de espécies de Dioscorea, que foram encontradas no México e na Guatemala e consideradas materiais iniciais (SVENDSEN \& SCHEFFER, 1982).

Ações terapêuticas de espécies vegetais podem ser descobertas por meio de outros usos, como ocorreu com a ação do contraceptivo masculino de polifenólico bissesquiterpene (gossipol), isolada do Gossypium sp (algodão), em 1899. A descoberta dessa ação terapêutica do gossipol ocorreu na década de 50 , quando foi verificado que a baixa taxa de natalidade encontrada em algumas áreas da China estava relacionada ao consumo de óleo da semente do algodão em salada (SVENDSEN \& SCHEFFER, 1982; JAROSZEWSKI, 1984).

Uma outra função muito importante da etnobotânica é que ela pode possibilitar a integração do sistema oficial de saúde com o tradicional ${ }^{5}$. Essa integração já é uma prática antiga em alguns países, principalmente nos orientais. Em outros, a prática da integração entre esses dois sistemas é mais recente. Entre os paises que integraram a medicina tradicional aos sistemas de assistência a saúde primária, destacam-se: China, México, Nigéria e Tailândia (BALICK \& COX, 1997), Vietnã (BORN et al., 1996a).

Quanto ao Brasil, essa integração ocorre de maneira subjacente (não oficializada), apesar de haver algumas tentativas de oficializá-la. A população brasileira, principalmente a pobre, usa muitos remédios caseiros (da medicina tradicional), à base de plantas medicinais. Por isso, a população brasileira está entre os $80 \%$ da população dos países em desenvolvimento da América Latina, Ásia e África, que dependem diretamente das plantas medicinais para cuidar da saúde, segundo as estimativas da Organização Mundial da Saúde (FARNSWORTH, \& SOEJARTO, 1991).

No Brasil, além dessa integração não estar oficializada, há ausência de incentivo do uso da medicina tradicional e há, até mesmo, médicos que proíbem seus pacientes, financeiramente carentes, de usarem plantas medicinais. Esses médicos são respaldados, até certo ponto, pelo sistema de saúde, que não estimula o uso adequado de fitoterápicos. Isso quer dizer que não há o desenvolvimento das ações necessárias para

${ }^{5}$ Sistema tradicional de saúde refere-se ao sistema usado pela população, em geral, para curar, prevenir e aliviar seus males físicos, da alma e da mente. Ele pode ser chamado de Medicina Popular (CAMARGO, 1985), Medicina Rústica (ARAÚJO, 1979). 
que ocorra a integração entre os dois sistemas. Há várias razões para isso, particularmente o fato de o atual sistema não treinar nem capacitar os profissionais de saúde, especialmente os médicos, para o uso adequado de fitoterápicos.

Há vários motivos para ocorrer esse descompasso entre a medicina oficial e a tradicional no Brasil. Dentre eles, podem ser citados: a cultura cartesiana predominante; a cultura popular e as condições financeiras da população brasileira, que não possui dinheiro suficiente para comprar os remédios sintéticos de altos preços.

Além de o Brasil ser o país número um em megabiodiversidade, também apresenta uma diversidade cultural muito rica no que se refere ao uso de recursos naturais para aliviar, curar e prevenir os males físicos, mentais e espirituais. Segundo GEREZ \& PEDROZA (1987), o Brasil é um dos países em desenvolvimento que depende muito de drogas importadas. Essa dependência causa dificuldades para estabelecer políticas de saúde eficientes. No Brasil, $84 \%$ de todas as drogas são importadas. Mais de $60 \%$ de todas as drogas processadas são consumidas por apenas $23 \%$ da população. Isso significa que cerca de $77 \%$ da população brasileira depende exclusivamente das plantas medicinais.

O uso da medicina tradicional (medicina rústica ou medicina popular) no Brasil, é realizado tanto por populações rurais como por populações urbanas que vivem em cidades grandes, como São Paulo, ou em regiões metropolitanas dessas cidades. Um exemplo para o segundo caso, é a importância e o uso de fitoterapia por benzedeiras, particularmente pelas da Aldeia de Carapicuíba, segundo BORN et al. (1989a).

Dentre as (cerca de) 90 espécies vegetais citadas, as mais indicadas pelas benzedeiras entrevistadas foram as que seguem: Chenopodium ambrosioides; Mentha spicata; Mentha pulegium (poejo) e Ruta graveolens (arruda). Os materiais vegetais eram usados de diferentes maneiras, principalmente contra verminoses, doenças das vias respiratórias e contusões externas, predominando a infusão e a decocção. Os materiais vegetais eram obtidos em quintais (de plantas cultivadas em pequenos canteiros ou aquelas de ocorrência espontânea), terrenos baldios (ocorrência espontânea) e no comércio (feiras livres, camelôs, casas de umbanda, supermercados, farmácias, entre outros) (BORN et al.,1989a).

Um outro exemplo do uso de plantas medicinais por população urbana foi verificado por BORN (1990) no Parque Paulistano do bairro de São Miguel Paulista da cidade de São Paulo. Foram entrevistadas 138 pessoas, das quais cerca de $90 \%$ eram 
mulheres donas-de-casa, que usavam 707 receitas com 134 espécies vegetais diferentes contra 58 tipos de problemas de saúde. Os problemas de saúde mais citados foram, em ordem decrescente: gripe, resfriado, tosse, bronquite e "nervoso"(necessidade de calmantes). As espécies mais citadas foram também em ordem decrescente de citação: Mentha pulegium (poejo), Mentha sp (hortelã) e Cymbopogon citratus (capim-santo). Analogamente ao que se verificou no trabalho realizado em Carapicuíba (BORN et al., 1989a), esse conhecimento era transmitido de mãe para filhos, principalmente filhas. Havia troca de informações entre as mulheres; esse conhecimento era modificado, aprimorado e acrescido de outros a partir de informações recebidas pelas mulheres via meios de comunicação, especialmente a televisão. Outra semelhança entre esses dois trabalhos foi que em ambos as guias principais (aquelas que detinham maior e mais aprimorado conhecimento) da pesquisa eram mulheres que desempenhavam importantes papéis de liderança nas comunidades, seja no âmbito religioso, seja no âmbito político (organização comunitária). Além disso, outro ponto em comum foi que ambas as comunidades gostariam de ter o uso de fitoterápicos implantado no sistema oficial de saúde, ou seja elas gostariam de receber informações dos próprios médicos para poder aprimorar o uso das plantas medicinais, o que pode ser verificado nos seguintes depoimentos das entrevistadas do Parque Paulistano (BORN, 1990):

"Tenho necessidade de ser informada se estou usando os remédios de plantas de maneira correta, apesar de a minha mãe e a minha avó já usarem e terem me ensinado." (Sra. Carmem)

"Os remédios de plantas são mais baratos e é mais fácil encontrá-los." (Sra. Maria).

A falta de um consenso claro sobre os objetivos básicos da etnobotânica e da metodologia que poderia ser usada para realizar os estudos têm impedido o desenvolvimento de uma abordagem unificada. Por outro lado, tem intensificado os debates, os estudos, os intercâmbios entre etnobotânicos e, conseqüentemente, tem enriquecido o conhecimento dessa etnociência. Isso já foi observado em 1991, quando o Programa das Nações Unidas para o Desenvolvimento (PNUD) realizou um workshop internacional sobre Intercâmbio Etnobotânico entre Amazônia e a Ásia e financiou 
projetos conjuntos (ver 2.1 - O Vitae Civilis).

Várias outras ações foram realizadas, visando promover maior discussão a fim de se chegar a um consenso sobre as abordagens e metodologias usadas na etnobotânica. Entre elas, cito o boletim Biological Conservation Newsletter, editado pelo Smithsonian Institution, para divulgar os trabalhos em etnobotânica e promover intercâmbio entre os pesquisadores. Esse boletim foi criado durante um encontro internacional, em Nova York, 1991, promovido pela Rainforest Alliance e New York Botanical Garden.

As pesquisas em etnobotânica e em etnofarmacologia, orientadas para a ação, por mim realizadas - projeto Juréia-Itatins e projeto Intercâmbio com o Vietnã foram apoiadas em uma abordagem metodológica que tem como base o compromisso com o grupo de estudo, ou seja, apoia-se na pesquisa participativa. Isso inclui, no mínimo, o que segue:

- cooperação e compromisso ético dos pesquisadores e de uma instituição em retornar os resultados obtidos e analisados ao grupo de estudo e às instituições envolvidas;

- a necessidade de os pesquisadores e as instituições diretamente envolvidas terem compromisso com o grupo, usando a etnobotânica e a etnofarmacologia como um instrumento para mobilizar o grupo e para facilitar o atendimento de reivindicações do grupo em estudo;

- procurar promover ações, até onde for possível, para garantir os direitos de propriedades intelectuais das comunidades e dos indivíduos.

É necessário, também, garantir a repartição dos benefícios financeiros provenientes do uso desses conhecimentos tradicionais, conforme estipulado na Convenção de Diversidade Biológica, assinada durante a Rio-92 (BORN \& BORN, 1996).

Os objetivos da pesquisa devem ser claramente explicados ao grupo cultural que está sendo estudado. É importante entender o modo de vida do grupo em estudo. Para isso, é necessário levantar dados sociais, culturais, econômicos e políticos para que seja feito um diagnóstico de tais aspectos e para que sejam incluídas e analisadas as reivindicações do grupo. É preciso também levantar dados detalhados das preparações fitoterápicas, posologia, contra-indicações, efeitos pós-uso, nomes das plantas etc. (BORN, 1998). 
É melhor que os diálogos entre o entrevistado e o entrevistador ocorram no local de coleta da planta, onde o remédio é feito, ou seja, que as informações detalhadas sejam obtidas no cotidiano do grupo cultural (BORN, 1998).

As plantas citadas por um entrevistado especifico devem ser por ele identificadas e após essa identificação, material da planta, preferencialmente fértil, deve ser coletado para realizar a identificação botânica (RODRIGUES, 1998).

Todas as informações obtidas e observadas devem ser descritas em fichas específicas e/ou relatos de campo, conhecidos como etnografias. Para a leitura e as análises qualitativas e quantitativas dos dados, procuram-se usar bancos de dados que possibilitem os agrupamentos e cruzamentos dos dados (BORN, 1998).

Os dados obtidos e analisados em um levantamento etnofarmacológico (ou etnobotânico) são usados para realizar vários outros estudos. Para melhor compreensão, será apresentado um esquema que indica os tipos e a seqüência de estudos a serem realizados com as plantas medicinais empregadas na medicina popular. Com base no esquema de CARLINI (1983) e de ELISABETSKY \& SETZER (1985), acrescentei BORN (1998) - a questão da conservação das plantas medicinais, no nivel E do esquema referido e apresentado no esquema 1. 

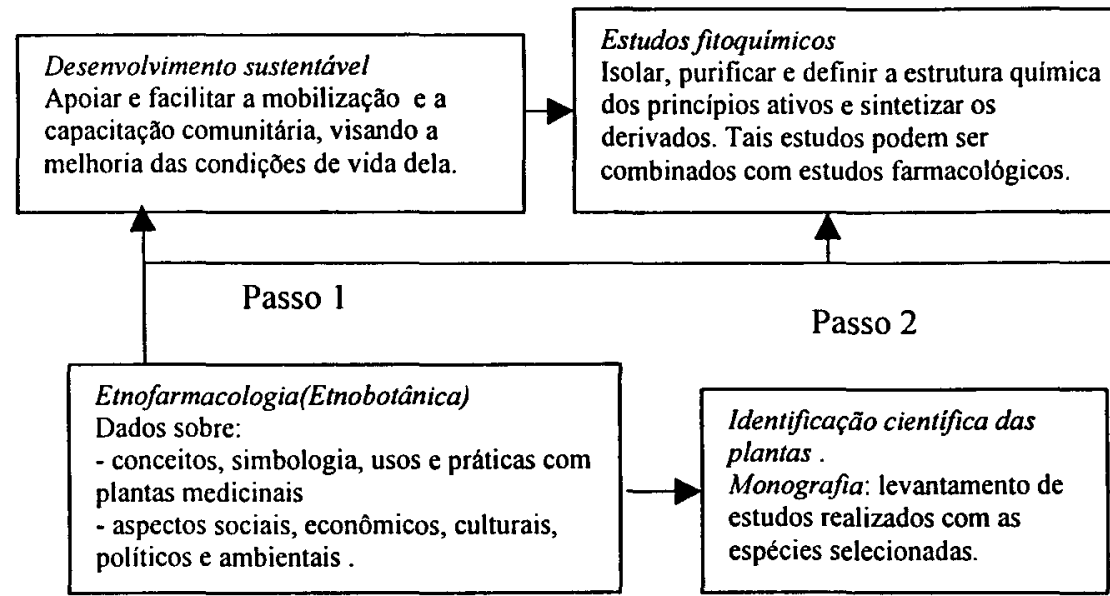

Estudos fitoquímicos

Isolar, purificar e definir a estrutura quimica

dos principios ativos e sintetizar os

derivados. Tais estudos podem ser

combinados com estudos farmacológicos.
Devolução dos resultados aos

usuários originais (cursos,

folhetos, hortas, etc.).
Espécies comercializadas

Realizar estudos sobre: manejo

sustentável, cultivo, reprodução,

beneficiamento, transporte,

armazenagem e mercado.
Devolução dos resultados

aos usuários originais

(cursos, folhetos, hortas,

etc.).
Comercialização das plantas in

natura (material seco)

Informar o nome cientifico e o

popular das plantas, a validade do

produto e data da coleta.
Comercialização dos

produtos fitoterápicos

(simples, estabilizados e

estandardizados), após a

autorização das instâncias

competentes.

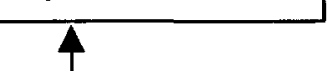

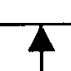
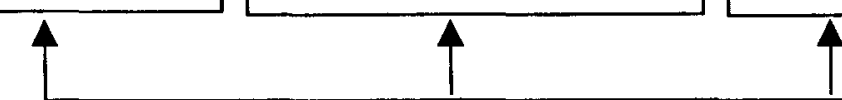

Passo 3

Farmacologia

Avaliação da ação farmacológica indicada pelos usuários e da toxicologia da preparacão popular.

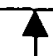

\section{Estudos fitoquimicos}

Isolar, purificar e definir a

estrutura química dos

principios ativos e sintetizar os

derivados. Tais estudos podem

ser combinados com estudos

farmacológicos.

\section{Passo 4}

Farmacologia Clínica Ensaio clinico controlado com a preparaca popular
Espécies comercializadas Realizar estudos sobre: manejo sustentável, cultivo, reprodução, beneficiamento, transporte, beneficiamento, transporte
armazenagem e mercado.

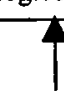




\subsection{Plantas medicinais}

Serão apresentados aspectos sobre manejo sustentável de plantas medicinais, seu mercado e sobre questões legais referentes ao acesso, à exploração e à comercialização de plantas medicinais. Também serão mencionados alguns aspectos legais do uso de fitoterápicos e da propriedade intelectual das comunidades tradicionais.

No caso do manejo sustentável, serão apresentadas algumas premissas usadas para realizar tais estudos e a parte do projeto Da mata à casa que trata dos estudos desenvolvidos sobre manejo sustentável de espécies medicinais de Mata Atlântica. Nesse último caso, serão apresentados, brevemente, a experiência, a abordagem filosófica e alguns dados obtidos.

Nas questões referentes ao mercado de plantas medicinais, serão tratados, brevemente, aspectos da importância econômica das plantas medicinais dos trópicos, tanto para os países em desenvolvimento como para os desenvolvidos. Serão apresentados também dados sobre o mercado de plantas medicinais na região metropolitana da cidade de São Paulo.

\subsubsection{Manejo sustentável de plantas medicinais da Mata Atlântica}

As florestas tropicais apresentam um equilíbrio dinâmico extremamente delicado, com intrincadas relações entre espécies. Assim, o manejo de suas espécies deve levar em consideração a manutenção da diversidade biológica e genética para não ocorrer perda de diversidade genética dentro da espécie manejada ou mesmo o colapso do ecossistema (JANZEN, 1980; MYERS, 1992). Poderia ocorrer um colapso, por exemplo, se as redes de dispersão de sementes, responsáveis pela distribuição e densidade demográfica dos indivíduos vegetais, bem como pela alimentação e pelo abrigo da fauna, fossem alteradas por uma redução de produtividade decorrente da diminuição da população dos indivíduos maduros (adultos) (JANZEN, 1980).

Para evitar esse colapso, é necessário realizar o manejo sustentável, que pode ser definido como "a forma socialmente justa e economicamente viável de exploração do 
ambiente que garanta a perenidade dos recursos ambientais renováveis e dos processos ecológicos, mantendo a biodiversidade e os demais atributos ecológicos".(IUCN, PNUMA, WWF, 1992).

Segundo o conceito apresentado acima, para realizar o manejo sustentável de recursos naturais renováveis, inclusive de plantas medicinais, é necessário que haja sustentabilidade em todas as dimensões do desenvolvimento, ou seja, é necessário que as sustentabilidades parciais e as esferas desse desenvolvimento sejam consideradas e atingidas, conforme foi apresentado no item 3.1. Sustentabilidade do desenvolvimento.

Para se ter a sustentabilidade ecológica, segundo a ciência florestal, é necessário realizar estudos para obter indicadores técnicos que possam ser empregados para estabelecer os parâmetros ecológicos a serem usados nos planos de manejo sustentável de cada espécie. É necessário, portanto, definir as espécies e as áreas a serem manejadas, a porcentagem de volume de biomassa por hectare, o ciclo de corte e o modo de realizar a extração planejada, levando-se em conta que haverá manipulação do estoque e interferências sobre as condições de regeneração da população ou de indivíduos da espécie considerada. Deve-se pensar, também, na relação entre espécies e também entre plantas e animais, ou seja nas várias e complexas relações existentes em um ecossistema ou mesmo entre diversos ecossistemas (PAVAN, 1994; REIS, 1996; BORN, 1997).

No olhar da ciência florestal, o manejo sustentável ou o manejo em regime de rendimento sustentável é definido por alguns autores, segundo REIS (1996) como a exploração cíclica dos "juros florestais", ou seja, há manutenção do "capital florestal" (REIS, 1996) ou do "capital natural" (GUIMARÃES \& MAIA, 1997) que é representado pela diversidade genética e biológica das espécies e pelo estoque ou número de indivíduos existentes (biomassa original) em determinada área de floresta. Poderia ser definido também como sendo a manutenção da biomassa original dos indivíduos manejados e a retirada periódica do aumento de biomassa (ou seja, retirar o incremento de biomassa no ciclo considerado) mediante a observação de uma periodicidade de supressão de indivíduos, ou de parte destes, de forma a proporcionar a retomada dos índices iniciais, após determinado tempo (REIS, 1996).

Garantir uma exploração cíclica e o equacionamento da exploração de cada espécie individualmente, são os principais desafios para a implantação de um sistema de manejo florestal de caráter ecologicamente sustentável (FANTINI et al., 1992). Para que 
isso possa ocorrer, é necessária a geração de dados que possibilitem a elaboração de parâmetros ecológicos. Para isso, é muito importante que vários profissionais, tais como biólogos, agrônomos, engenheiros florestais, geógrafos e outros, trabalhem de maneira integrada e troquem conhecimentos e experiências específicas (REIS, 1996).

Segundo FANTINI et al. (1992) e REIS (1996), a geração desses dados para a definição de parâmetros ecológicos deve ser realizada de forma individual para cada espécie e fundamentada no caráter cíclico e no equacionamento da exploração da referida espécie. Para tanto, a geração de dados, segundo esses autores (op. cit.), deve ser feita com base:

- na análise da composição florística e da estrutura da floresta;

- em estudos demográficos, ou seja, na caracterização da distribuição e da quantidade de classes de indivíduos por variáveis de interesse (Ex.: para a exploração de plantas que fornecem madeira, as variáveis de interesse mais usadas são altura $\mathrm{e}$ diâmetro à altura do peito);

- em observações da biologia reprodutiva da espécie a ser manejada;

- em estudos sobre a regeneração natural (número de indivíduos jovens) e sobre o número de indivíduos reprodutivos necessários para a manutenção do valor populacional original - em termos demográficos e genéticos — da espécie a ser manejada;

- na avaliação da biomassa existente (estoque disponível) e na determinação do incremento anual da biomassa da espécie a ser manejada;

- na determinação da quantidade e da distribuição dos indivíduos porta-sementes e daqueles que compõem a população jovem da espécie a ser manejada;

- na determinação do limite de corte (LC) - ou seja, quanto de biomassa pode ser extraída e como isso deve ser feito - e do intervalo de corte (IC) - ou seja, nas observações de regeneração dos indivíduos e da população da espécie a ser manejada. $\mathrm{O}$ intervalo de corte poderia ser definido também como a freqüência com que os indivíduos podem ser cortados para permitir a regeneração da biomassa.

Ainda, segundo esses autores (op. cit.), após a definição dos indicadores ecológicos e a realização da exploração da espécie estudada, deve-se fazer reavaliações da exploração, tanto em relação à espécie estudada como no que diz respeito à floresta como um todo. 
Como pode ser verificado, os estudos para obter tais indicadores ecológicos, à luz da ciência ocidental, exigem um período longo, recursos financeiros consideráveis e profissionais de várias áreas como, por exemplo, biólogos, engenheiros florestais, ecólogos, botânicos etc. A complexidade e os custos desses estudos podem aumentar quando se usa a etnobotânica como estratégia para a obtenção de tais indicadores ecológicos ou outros parâmetros que interferem em outras sustentabilidades parciais. Qualquer que seja o caso, quando se trata de plantas medicinais, tais estudos se tornam mais complexos pelo fato de não haver sido estabelecida, à luz da ciência ocidental, a metodologia que pode ser usada para definir tais indicadores ecológicos. A metodologia definida existente quase sempre se refere a plantas que fornecem madeira e não folhas, caules, flores, sementes e raízes, como é o caso das plantas medicinais.

Conforme foi apresentado no item 2.1 - O Vitae Civilis, foram iniciados os primeiros estudos para se definir a metodologia a ser usada em pesquisas de manejo sustentável de espécies medicinais. Dando continuidade a esses estudos, realizados no âmbito do projeto Juréia-Itatins, uma parte do projeto Da mata à casa trata da pesquisa em inventário florestal e da regeneração de espécies medicinais de Mata Atlântica. Consoante ao que foi apresentado anteriormente, a seleção das propriedades, onde estão sendo realizados os estudos, assim como a seleção das espécies medicinais, atende à abordagem filosófica do projeto Da mata à casa.

A partir de dados preliminares sobre as áreas de extração mais usadas, fornecidos por extratores e produtores de plantas medicinais, foi realizado o zoneamento de referência para amostragem vegetal de Mata Atlântica na região do Vale do Ribeira (PAVAN \& BORN, 1995). Posteriormente, foram definidas as propriedades, relacionadas abaixo, a serem usadas para realizar os estudos de manejo sustentável (BORN, 1997; PAVAN, 1999):

\section{Propriedades selecionadas para estudo de manejo sustentável}
a. Sítio Vale Dourado, do Sr. Augusto Franceschet, no Município de Eldorado;
b. Sítio Uzuelli, do Sr. José Uzuelli Villar, no Município de Registro;
c. Sítio Lambari, do Sr. José Ferreira dos Santos, no Município de Registro;
d. Sítio José Messias, do Sr. José Messias, no Município de Registro;
e. Sítio Deus é Pai, do Sr. Valter Elias Rocha, no Município de Registro;
f. Sítio Araribá, do Sr. Emil Leib, no Município de Registro. 
As espécies selecionadas para realizar a pesquisa de amostragem para o manejo sustentável estão apresentadas no quadro 1. Para realizar a pesquisa em ensaios de poda, as espécies selecionadas foram as mesmas, com exceção de Sorocea bonplandii (Baill.) W.C. Burguer (espinheira-santa) e inclusão de Vernonia sp (assa-peixe) (BORN, 1997; BORN, 1999).

Quadro 1: Relação das espécies selecionadas para os estudos de manejo sustentável, no âmbito do projeto Da mata à casa.

\begin{tabular}{|c|c|c|c|}
\hline Nome popular & Família & Nome científico & Espécies afins \\
\hline \multicolumn{4}{|c|}{ ARBÓREAS } \\
\hline espinheira-santa & Moraceae & $\begin{array}{l}\text { Sorocea bonplandii (Baill.) } \\
\text { W.C. Burguer }\end{array}$ & $\begin{array}{l}\text { Zollernia ilicifolia (Brongn.) } \\
\text { Vog./Leg-Caesalpiniaceae }\end{array}$ \\
\hline $\begin{array}{l}\text { guaçatonga } \\
\text { (erva-de- } \\
\text { macuco) }\end{array}$ & Flacourtiaceae & Casearia sylvestris Sw. & Não há. \\
\hline sene (caquera) & $\begin{array}{l}\text { Leg- } \\
\text { Caesalpiniaceae }\end{array}$ & $\begin{array}{l}\text { Senna multijuga (L.C.Rich) } \\
\text { Irwin \& Barneby }\end{array}$ & Não há. \\
\hline embaúba & Cecropiaceae & Cecropia pachystachia Trèc & $\begin{array}{l}\text { embaúba vermelha - } \\
\text { Cecropia glaziovi } \\
\text { Snethl./Cecropiaceae }\end{array}$ \\
\hline $\begin{array}{l}\text { covatã (chá-de- } \\
\text { bugre) }\end{array}$ & Sapindaceae & Cupania oblongifolia Mart. & Não há.* \\
\hline carobinha & Bignoniaceae & Jacaranda puberula Cham. & Não há.* \\
\hline \multicolumn{4}{|c|}{ ARBUSTIVA } \\
\hline pariparoba & Piperaceae & Piper cernuum Vellozo & Não há.* \\
\hline \multicolumn{4}{|c|}{ HERBÁCEA } \\
\hline carqueja & Asteraceae & $\begin{array}{l}\text { Baccharis gaudichaudiana } \\
\text { A.P.De Candolle }\end{array}$ & $\begin{array}{l}\text { Carqueja-doce: Baccharis } \\
\text { trimera (Less) DC. e outras } \\
\text { amargas: Baccharis sp }\end{array}$ \\
\hline $\begin{array}{l}\text { erva-de-são-joão } \\
\text { (mentrasto) }\end{array}$ & Asteraceae & Ageratum conyzoides $\mathrm{L}$. & Não há. \\
\hline
\end{tabular}

*Segundo PAVAN (1999), alguns extratores mencionaram a existência de espécies afins para as plantas indicadas, mas a identificação botânica das amostras coletadas indicou uma única espécie.

De acordo com a bibliografia levantada sobre pesquisas em manejo sustentável de espécies medicinais da Mata Atlântica, a parceria-estratégica do Vitae Civilis (PAVAN, 1999), proporcionou a obtenção dos, provavelmente, primeiros indicadores ecológicos do manejo sustentável das espécies listadas no quadro 1. Os principais aspectos estudados nessa parceria, conforme BORN (1997) e PAVAN (1999) foram: 
- Estimativa de biomassa: foram definidos modelos indicados para estimar a biomassa das espécies selecionadas, para a conversão de massa úmida, para a massa seca e para o porcentual indicativo de perdas no processo de trituração.

- Sistema de amostragem para plantas arbóreas e arbustivas (estratificação e inventário florestal): as propriedades foram divididas em quatro estratos principais (capoeirão/capoeira alta; capoeira; campo; brejo), e inventariados os dois primeiros estratos; foram definidos tamanho das parcelas $\left(300 \mathrm{~m}^{2}: 10 \mathrm{~m} \times 30 \mathrm{~m}\right)$ e sua distribuição com base em dois sistemas de amostragem - o sistemático e o estratificado aleatório. $\mathrm{O}$ sistemático foi o mais indicado, quando se considera $\mathrm{o}$ aspecto econômico do uso dos sistemas.

- Monitoramento do crescimento das espécies estudadas: foi verificado que as populações estudadas não apresentavam estabilidade; as maiores taxas de crescimento de biomassa anual foram verificadas para covatã e sene e as menores foram para pariparoba e espinheira-santa.

- Intensidade de amostragem e tamanho de parcelas para plantas herbáceas.

No âmbito ainda do projeto Da mata à casa, o Vitae Civilis está realizando estudos sobre ensaios de poda das espécies medicinais para definir intensidade, periodicidade, forma e época adequadas de extração. Para isto, o Vitae Civilis está usando informações do manejo tradicional no que se refere à intensidade e à periodicidade da poda (BORN, 1999).

\subsubsection{Aspectos do mercado de plantas medicinais}

Há várias evidências de que as plantas medicinais têm grande importância econômica, tanto nos paises em desenvolvimento como nos desenvolvidos.

Nos Estados Unidos da América, no período de 1959 a 1980, 25\% de todas as prescrições continham extratos vegetais ou princípios ativos preparados a partir de angiospermas e gimnospermas (FARNSWORTH ET AL., 1985). Esses autores (op. cit.) fizeram uma lista de 119 substâncias químicas diferentes derivadas de plantas que são consideradas drogas importantes em vários países. Eles demonstraram também que $74 \%$ dessas 119 drogas foram descobertas a partir de estudos químicos para isolar as substâncias ativas de plantas utilizadas na medicina tradicional. 
Em 1985, o valor do mercado mundial das drogas em geral foi estimado em 90 bilhões de dólares americanos, enquanto o valor do mercado de drogas provenientes de plantas medicinais foi estimado em 43 bilhões de dólares americanos, isto é, cerca de $50 \%$ do valor do mercado mundial (ELISABETSKY \& SHANLEY, 1994). A importância das plantas medicinais no mercado internacional foi verificada também em 1996, pois o total das vendas de fitoterápicos na Alemanha, França, Itália, Espanha, Inglaterra e na Holanda foi da ordem de $\$ 7$ bilhões de dólares americanos (KING et al., 1998).

A Organização Mundial de Saúde prevê que o mercado mundial de fitoterápicos movimentará, no ano 2000 , cerca de $\$ 500$ bilhões de dólares americanos, somente na Europa, contra um volume de vendas de US\$500 milhões registrados em 1980 . No Brasil, só nos últimos dois anos, o comércio desse tipo de produto aumentou em $20 \%$ (COELHO, 1999).

As plantas medicinais têm um grande valor mercadológico graças ao seu uso na descoberta de novas substâncias terapêuticas (MAXWELL, 1984), em fitoterápicos, em cosméticos, entre outros.

No que se refere a custos de síntese e extração de substâncias, os custos da extração comercial de substâncias provenientes de plantas medicinais podem ser menores do que os da síntese de drogas. Isso foi verificado na metade da década de 70 , quando se estimou que a síntese da droga reserpine (extraída de Rauwolfia sp., hipotensivo) custou cerca de US\$ 1,25 por grama, enquanto a extração comercial da planta custou US\$ 0,75 por grama (OLDFIELD, 1984 apud PLOTKIN, 1991).

Outro aspecto da importância econômica das plantas medicinais é observado no programa do Instituto Nacional do Câncer dos Estados Unidos da América (INC) e nos acordos de bioprospecção ${ }^{6}$, realizados por várias empresas, por seus coletores (chamados também de intermediários) e pelos paises-fonte. Nesses acordos, quase sempre, estão envolvidas grandes empresas e instituições de pesquisa com destaque mundial, o que pode ser verificado na lista, apresentada abaixo, dos 20 acordos realizados entre as empresas e seus respectivos coletores (REID et al. 1993 apud REID

${ }^{6}$ Bioprospeção é a busca de produtos naturais para o uso humano. É a busca de metabólicos secundários a partir de fontes naturais (vegetal, animal e microorganismos). É a busca de genoma de importância econômica (CHAPELA, 1996). 
et al., 1996).

1. Abbott Laboratories (University of Illinois, coletores independentes);

2. Boehringer Ingelheim (University of Illinois, New York Botanical Garden - pilot program em 1986 - e coletores independentes);

3. Bristol-Myers Squibb (Scripps Institute of Oceanography, Oncogen - pokeweed protein- e coletores independentes);

4. Ciba-Geigy (Chinese Academy of Sciences, Harbor Branch Oceanographic Institute, e coletores independentes);

5. Eli Lilly (em colaboração com o INC, Shaman Pharmaceuticals, e pesquisadores independentes);

6. Inverni della Beffa (coletores da empresa e coletores independentes na Ásia, África, e América do Sul);

7. Merck \& Co., Inc. (INBio, New York Botanical Garden, and MYCOsearch);

8. Miles, Inc. (companhias contratadas e coletores independentes);

9. Monsanto (Missouri Botanical Garden);

10. National Cancer Institute (U.S. Department of Agriculture - 1960-80; Missouri Botanical Garden; New York Botanical Garden; University of Illinois; Kunming Institute of Botany, China; Central Drug Research Institute, India; Brigham Young University; Harbor Branch Oceanographic Institute; Australian Institute Of Marine Sciences; Coral Reef Research Foundation; Smithsonian Oceanographic; University of Connecticut; University of Hawaii at Manoa; University of Miami; Michigan Biotechnology Institute; e Tel Aviv University);

11. Pfizer (Natural Product Sciences - New York Botanical Garden);

12. Pharmagenesis (especialistas da empresa e mais de 50 instituições distribuidas na China e em outros países da Ásia);

13. Phytop'harmaceutical (University of São Paulo, Brasil; Chinese Academy of Sciences; coletores independentes);

14. Rhone-Poulene Rorer (University of Hawaii; Beijing Medical University; Shanghai Medical University; Tianjin Plant Institute, China e coletores independentes);

15. Shaman Pharmaceutical, Inc. (botânicos da empresa e colaboradores da África, da Ásia e da América do Sul);

16. SmithKline Beecham (Biotics, Ltd.; Royal Botanic Gardens, Kew; University of Virginia; Scripps Institution of Oceanography; Morris Arboretum, University of 
Pennsylvania; MYCOsearch, e coletores da empresa);

17. Sphinx Pharmaceuticals (Biotics, Ltd.; coletores independentes);

18. Sterling Winthrop (Mississippi State University, Brigham Young University, New York Botanical Garden e coletores independentes);

19. Syntex Laboratories (Chinese Academy of Sciences);

20. Upjohn Company (Shangai Institute of Materia Medica).

Em 1991, o Instituto Nacional do Câncer dos Estados Unidos da América (INC) assinou contratos no valor de US\$ 2,5 milhões com o New York Botanical Garden, o Missouri Botanical Garden e a University of Illinois. Tais contratos objetivavam coletar e testar espécies vegetais com atividade anticâncer e anti-HIV (PLOTKIN, \& FAMOLARE, 1992). A coleta das plantas, nesse programa, é geralmente realizada usando a etnobotânica, por ser esta mais eficaz na descoberta de novas drogas (ver 3.2 Pesquisa etnobotânica). O INC gastou cerca de $\$ 60$ milhões de dólares americanos para realizar tais análises em amostras de plantas e de animais, em 1993, segundo GRIFO (1996).

Apesar desse avanço no mercado mundial de plantas medicinais, as empresas que trabalham com fitoterapia pagam um preço mínimo por um grande volume de material vegetal. Processam esse material, elaboram seus produtos e os vendem por preços muito altos (KING, et al.,1996). Esses autores (op. cit.) levantaram cerca de 100 empresas que vendem produtos elaborados a partir de plantas, dentre as quais apenas uma empresa indicava preocupações com a conservação das plantas medicinais e em retornar benefícios às comunidades fornecedoras do conhecimento tradicional sobre o uso das plantas medicinais. Esse retorno seria a partir das vendas de produtos.

A China é um dos poucos grandes exemplos das potencialidades do uso terapêutico e econômico de plantas medicinais. Na China, WANG (1983 apud ELISABETSKY, 1986) verificou que, na época da sua pesquisa, esse país tinha $400 \mathrm{mil}$ hectares cultivados com plantas medicinais, 800 indústrias farmacêuticas nacionais, produzindo 2 mil variedades de medicamentos e empregando 80 mil trabalhadores. Quando se consideram todas as pessoas envolvidas com plantio, processamento e distribuição de ervas medicinais, a cifra de 80 mil trabalhadores eleva-se para 220 mil.

Quanto ao mercado de plantas medicinais e aromáticas na região metropolitana da cidade de São Paulo, segundo constatei — BORN (1999) —, esse mercado é composto por onze segmentos que incluem: extrator (raizeiro ou erveiro) e produtor de 
plantas medicinais e aromáticas, farmácias (inclusive de manipulação e homeopáticas), supermercados e lojas de produtos naturais, intermediário, atacadista, indústria farmacêutica, laboratório, casa de umbanda e feiras livre, mercado externo $\underline{\text { e }}$ consumidor. As relações comerciais entre esses segmentos são indiretas e complexas, conforme mostra o esquema 2.

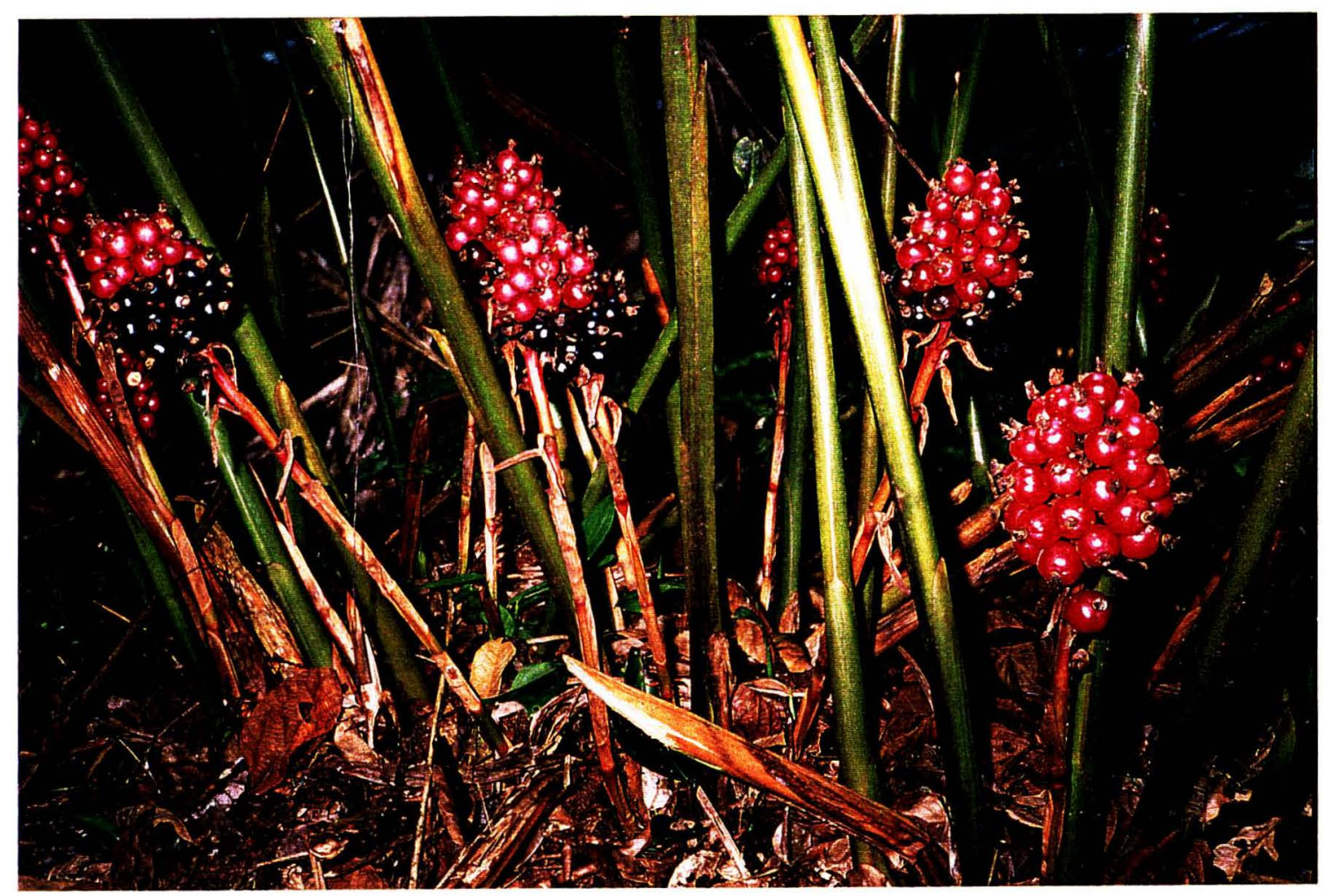

Foto 1. Capitiu, Renealmia petasites Gagnep. 
Esquema 2. - Relações comerciais entre os segmentos do mercado de plantas medicinais da região metropolitana de São Paulo. Extrator (mateiro, raizeiro ou erveiro) extrai as plantas que ocorrem espontaneamente em áreas naturais; Produtor (fazendeiro) cultiva, beneficia e comercializa as plantas; Intermediário compra de extratores e de produtores, estoca e vende para outros; Atacadista, semelhante ao intermediário, sendo que compra em quantidades maiores; Farmácias inclui também as de manipulação e homeopáticas. Fonte: BORN, 1999.

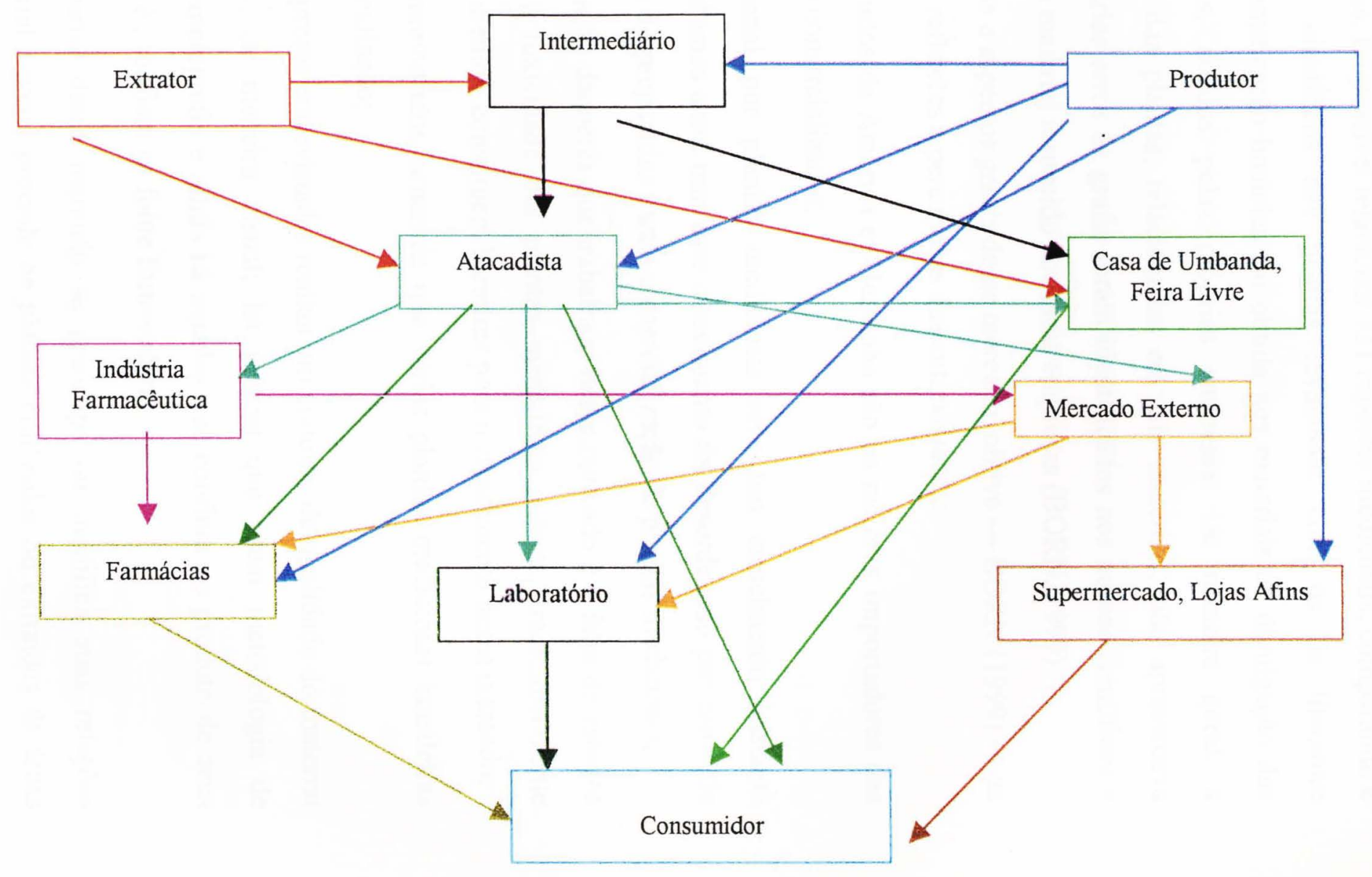


Pode-se observar no fluxograma do esquema que os extratores (mateiros, raizeiros ou erveiros) iniciam o fluxo do mercado e quase sempre eles vendem suas plantas para intermediários e atacadistas, entre outros. Dificilmente eles conseguem vender seus produtos para o consumidor da matéria-prima, seja fabricando os produtos seja embalando-os e vendendo-os como complemento alimentar.

Esse mercado trabalha com cerca de 963 plantas medicinais, identificadas por nomes populares. Destas, foi possível relacionar 731 espécies medicinais, comparando e corrigindo os nomes científicos das plantas levantadas com os da literatura especializada. Essa identificação botânica foi obtida nos materiais de divulgação das empresas entrevistadas, doados pelas próprias empresas. De maneira geral, a identificação botânica das plantas, relacionadas em tais materiais, não apresentava confiabilidade, pois vários erros de grafia foram identificados nos nomes científicos e nas famílias listadas no material fornecido por essas empresas (BORN, 1999).

No que concerne a aspectos gerais desse mercado, obtive - BORN (1999) - as seguintes informações, reflexões e percepções dos entrevistados:

- Japão, Estados Unidos da América e Alemanha são os maiores importadores das plantas medicinais comercializadas;

- A demanda nacional por plantas medicinais teve um crescimento bastante significativo nos últimos anos, mas esse crescimento foi desordenado por causa da entrada de pessoas despreparadas para a comercialização de plantas medicinais;

- A falta de capacitação daqueles que trabalham nesse mercado e a falta de estudos sobre a eficácia e toxicidade das plantas medicinais nativas, tradicionalmente utilizadas como remédios, constituem barreiras para o crescimento desse mercado;

- A maioria dos entrevistados concorda que várias plantas medicinais brasileiras estão em risco de extinção;

- A maioria das empresas entrevistadas realiza um controle de qualidade do material vegetal adquirido, de maneira visual; há poucas que usam metodologia de microscopia e cromatografia e ainda há aquelas que confiam no produto de seus fornecedores, isto é , confiam na fonte fornecedora.

Nenhum segmento desse mercado se preocupa ou modifica suas relações comerciais se o material vegetal procede de plantas cultivadas ou extraídas de áreas naturais, como por exemplo, da Mata Atlântica. Essas relações não são modificadas 
também se as plantas medicinais forem adquiridas de famílias que vivem em áreas naturais. Os levantamentos, realizados - BORN (1999) - em 1992 e atualizados em 1997, mostraram que os compradores não deixavam de abastecer o mercado, mesmo que a planta estivesse em risco de extinção, segundo os próprios entrevistados.

Outro estudo realizado - BORN (1999) - foi a comparação das espécies medicinais citadas nos referidos levantamentos de mercado, e as prováveis espécies exportadas no Aeroporto Internacional de Guarulhos, Estado de São Paulo, no período de março a dezembro de 1994, segundo SCHEFFER (1995). Esta autora (op. cit.), com base em uma lista de nomes populares de 49 plantas, levantou na literatura especializada 325 espécies prováveis de terem sido exportadas no mencionado período. Segundo meu estudo - BORN (1999) —, das 731 espécies levantadas no mercado da região metropolitana de São Paulo, 123 estavam citadas no trabalho de SCHEFFER (1995), ou seja, são exportadas.

\subsubsection{Questões legais}

A seguir serão apresentados alguns aspectos de temas que englobam as questões legais do acesso, da extração e da comercialização de espécies medicinais da Mata Atlântica; o uso de fitoterápicos bem como divisão dos benefícios provenientes do uso do conhecimento tradicional.

\subsubsection{Da exploração e comercialização de plantas medicinais da Mata Attântica}

A fiscalização e o controle da exploração e da comercialização de plantas medicinais da Mata Atlântica, na região do Vale do Ribeira são realizados pelo Ibama, pelo DEPRN e pela Polícia Florestal.

As legislações estaduais e federais que tratam da extração e da comercialização de plantas medicinais e de outros recursos naturais renováveis não apresentam a intergração, a uniformidade ou a complementaridade necessárias para o desempenho das funções desses órgãos, em uma mesma área e com os mesmos assuntos. Além disso, os instrumentos legais existentes não são suficientes para os órgãos governamentais desempenharem papéis de fiscalização, controle e orientação (HECK, 1996; BORN \& 
BORN, 1999).

No primeiro momento, em nosso trabalho - BORN \& BORN (1999)—, foram levantados cerca de 52 instrumentos legais que tratam, direta ou indiretamente, do controle da exploração e da comercialização de plantas medicinais. $O$ critério por nós utilizado (op. cit.) para selecionar os atos normativos foi a escolha de atos que dispõem sobre:

- conservação e proteção da biodiversidade;

- proteção e definição legal de ecossistemas;

- exploração de recursos naturais;

- exploração de recursos florestais;

- produção e comercialização de produtos florestais;

- manejo florestal sustentável;

- pesquisas científicas de recursos naturais; e

- termos e conceitos técnicos pertinentes.

Entre os instrumentos legais por nós compilados - BORN \& BORN (1999) -, serão listados abaixo e resumidos com comentários breves, no anexo 2 , alguns dos atos legais que dizem respeito à estrutura e ao funcionamento do Ibama, à exploração, à comercialização e ao transporte de plantas medicinais ou de seus produtos.

a) Estrutura e funcionamento do Ibama

São regidos principalmente pelos atos normativos a seguir:

- Decreto Lei $\mathrm{n}^{0}$ 289, de 28 de fevereiro de 1967;

- Portaria IBDF nº 377-P, de 9 de Junho de 1980;

- Lei $\mathrm{n}^{\mathrm{O}} 7.735$, de 22 de fevereiro de 1989;

- Decreto nº 97.946, de 11 de Julho de 1989.

b) Exploração de plantas medicinais

A exploração de recursos naturais renováveis é regida principalmente pelos seguintes atos normativos: 
- Instrução Normativa IBDF nº 001, de 11 de abril de 1980;

- Portaria Ibama nํ218, de 4 de maio de 1989;

- Ordem de Serviço Ibama/SUPES-SP nº 55, de 29 de outubro de 1991;

- Decreto nำ 750, de 10 de fevereiro de 1993;

- Decreto $\mathrm{n}^{\mathrm{0}} 1.282$, de 19 de outubro de 1994;

- Portaria Ibama no 48, de 10 de julho de 1995;

- Portaria Ibama no 113, de 29 de dezembro de 1995;

- Portaria Ibama nํ2, de 26 de abril de 1996;

- Portaria DEPRN 52, de 28 de dezembro de 1998.

c) Comercialização e transporte de plantas medicinais

São regidos principalmente pelos seguintes atos normativos:

- Portaria Normativa IBDF no 122-P, de 19 de março de 1985;

- Portaria Normativa IBDF no 302-P, de 9 de novembro de 1988;

- Portaria Ibama $\mathrm{n}^{\mathrm{O}} 732$, de $1^{\circ}$ de abril de 1991 ;

- Portaria SEMAN/PR nº 139, de 5 de junho de 1992;

- Portaria Ibama nº 44-N, de 6 de abril de 1993;

- Portaria Ibama no 83, de 15 de outubro de 1996.

\subsubsection{Uso de fitoterápicos}

O controle do uso de plantas para finalidades medicamentosas, no Brasil, só foi regulamentado com a publicação da Portaria $n^{0}$ 6/Secretaria de Vigilância Sanitária, de 31 de janeiro de 1995 (BRITO, 1996).

Antes da publicação dessa portaria, foi publicada uma outra, Portaria $\mathrm{n}^{0} 546-$ Ministério da Saúde, de 21 de maio de 1993, que criou o Grupo Consultor TécnicoCientífico (GCTC) da Secretaria de Vigilância Sanitária, com as seguintes incumbências:

- estabelecer a normatização, o controle de serviços, a produção, a armazenagem e a 
utilização de substâncias e produtos naturais;

- estabelecer normas internas de funcionamento;

- estabelecer prazo de 60 dias úteis, a partir da data da publicação da portaria, para apresentação de propostas preliminares de trabalho, relativos a produtos, serviços e à terapias alternativas.

De acordo com a portaria acima referida, o GCTC era supervisionado pela Divisão de Ecologia Humana e Saúde Ambiental do Departamento Técnico-Normativo da Secretaria de Vigilância Sanitária e composto por representantes do Ministério da Agricultura, da Central de Medicamentos, da Secretaria de Assistência à Saúde, da Coordenação Nacional de Fitoterapia em Saúde Pública, do Comitê Intertribal, e de algumas universidades e fundações brasileiras.

A Portaria n⿳0 6 - Secretaria de Vigilância Sanitária, de 31 de janeiro de 1995 (anexo 2) instituiu e normatizou o registro de produtos fitoterápicos no Sistema de Vigilância Sanitária, bem como estabeleceu as definições abaixo descritas:

a) Produto fitoterápico: é todo medicamento tecnicamente obtido e elaborado, empregando-se, exclusivamente, matérias-primas ativas vegetais com finalidade profilática, curativa ou para fins de diagnóstico, com benefício para o usuário. É caracterizado pelo conhecimento da eficácia e dos riscos de seu uso, assim como pela reprodutibilidade e constância de sua qualidade; é o produto final acabado, embalado e rotulado. $\mathrm{Na}$ sua preparação, podem ser utilizados adjuvantes farmacêuticos permitidos pela legislação vigente. Não podem estar incluidas substâncias ativas de outras origens, não sendo considerado produto fitoterápico quaisquer substâncias ativas, ainda que de origem vegetal, isoladas ou mesmo suas misturas.

b) Matéria-prima vegetal: planta fresca, droga vegetal ou preparado fitoterápico intermediário, empregado na fabricação de produto fitoterápico.

c) Droga vegetal: é a planta ou suas partes, que após sofrer processo de coleta, secagem, estabilização e conservação, justificam seu emprego na preparação do medicamento.

d) Preparado fitoterápico intermediário: é o produto vegetal triturado, pulverizado, rasurado, extrato, tintura, óleo fixo ou volátil, cera, suco e outros, obtido de plantas frescas e de drogas vegetais, por operações de fracionamento, extração, purificação ou concentração utilizado na preparação do produto fitoterápico. 
e) Princípio ativo: substâncias ou grupo delas, quimicamente caracterizados, cuja ação farmacológica é conhecida e responsável, total ou parcialmente, pelos efeitos terapêuticos do produto fitoterápico.

f) Marcadores: são constituintes quimicamente definidos, presentes na matéria-prima vegetal, preferencialmente os próprios princípios ativos, destinados ao controle de qualidade da matéria-prima vegetal, dos preparados fitoterápicos intermediários e dos produtos fitoterápicos.

\subsubsection{Da repartição dos benefícios provenientes do uso do conhecimento tradicional}

O retorno dos benefícios, financeiros ou não, vindos do uso do conhecimento tradicional das comunidades tradicionais é um dos assuntos mais comentados e polêmicos desse final de século, no campo das questões de desenvolvimento (BALICK, ELISABETSKY \& LAIRD, 1996; ORGANIZACIÓN PANAMERICANA DE LA SALUD, 1996; POSEY \& DUTFIELD, 1996; SWANSON, 1998).

Essa polêmica começa com dois termos muito usados: compensar e compartilhar benefícios. A Convenção da Diversidade Biológica ${ }^{7}$ utiliza o termo compartilhar benefícios, sharing, em inglês, em seu Art. 8j. Entretanto, nas discussões nacionais e internacionais para implementar esse dispositivo e princípio, diversos atores têm utilizado a expressão compensar, denotando arranjos que busquem dar algum retorno às comunidades que fornecem seus conhecimentos e recursos naturais, não obstante esse retorno não significa necessariamente uma distribuição eqüitativa e justa de todos os benefícios do desenvolvimento advindo daquele uso.

Segundo nosso estudo - BORN \& BORN (1996) —, a questão em pauta não é apenas compensar o conhecimento tradicional com dinheiro ou trocar esse conhecimento por outro benefício. A questão é mais complexa e profunda, pois

\footnotetext{
${ }^{7}$ A Convenção da Diversidade Biológica, em seu inciso ( $\mathrm{j}$ ), artigo 8, diz que há compromisso ético de pesquisadores, instituições, empresas, enfim de todos aqueles que trabalham direta ou indiretamente com o conhecimento tradicional, para repartir os beneficios provenientes do conhecimento tradicional.
} 
pesquisadores, empresas, governo, técnicos, ou seja, todos aqueles que estejam envolvidos, direta ou indiretamente, devem ter o compromisso com a comunidade fornecedora do conhecimento tradicional de compartilhar os benefícios, financeiros e outros, provenientes do uso comercial desse conhecimento. Esse compromisso com a comunidade detentora e fornecedora do conhecimento tradicional (conforme apresentado no item 2.2 - Pesquisa etnobotânica) passa, na verdade, pelo comprometimento, dos pesquisadores, das empresas, das instituições, dos governos, ou seja, por todos aqueles envolvidos com a melhoria das condições de vida da comunidade e com a conservação dos recursos naturais. A comunidade que forneceu o conhecimento tradicional ao pesquisador de determinada instituição ou empresa poderia, ou deveria, ser considerada proprietária do conhecimento fornecido, que pode ser reconhecido como um bem.

Diante da possibilidade e do potencial de gerar riquezas, o conhecimento tradicional, independente da existência de alguma lei expressa nesse sentido, é um bem apropriável juridicamente, portanto um patrimônio de seu titular (comunidade, curandeiro, país, continente etc.). O Direito Civil veda o enriquecimento ilícito - no que se refere ao terceiro que consegue a exclusividade no seu invento (patente) sem dar nenhuma contraprestação (repartição ou compensação) às comunidades que forneceram o conhecimento tradicional que é o ponto de partida para os estudos científicos (VITAE CIVILIS, 1995).

Como foi apresentado no item 3.3.2 - Aspectos do mercado de plantas medicinais, o conhecimento tradicional tem fornecido beneficios financeiros para a sociedade moderna e mais especificamente para as empresas, para os pesquisadores, para as instituições de pesquisas, entre outros, envolvidos com a descoberta de novos medicamentos, bem como com a elaboração e a comercialização de novos produtos a partir do conhecimento tradicional. Diante dessa realidade e de dificuldades financeiras e políticas enfrentadas pela grande maioria das comunidades detentoras e fornecedoras desse conhecimento (ver o caso da Juréia-Itatins no item 2.1 - O Vitae Civilis), é urgente, portanto, a necessidade de viabilizar, de fato, o retorno dos benefícios para as comunidades, bem como para os pesquisadores, para as instituições, e para o país de origem.

Essa constatação parece ser mais urgente para o país que detém maior biodiversidade e número de espécies endêmicas, ou seja, aquele que está no primeiro 
lugar no rank dos países que detém a megabiodiversidade: o Brasil. Para isso, é necessário que o Brasil tenha instrumentos legais que contemplem e considerem, de fato, a abordagem de compartilhar os benefícios, conforme já foi dito anteriormente. Além disso, é crucial que o governo brasileiro, seus técnicos, as empresas nacionais e toda a sociedade brasileira se conscientizem e se orgulhem de viverem no país que detém a maior megabiodiversidade do mundo, além de apresentar também grande diversidade cultural. Essa diversidade biológica e cultural tem inclusive valor econômico.

Há grandes dificuldades para viabilizar o compartilhamento dos benefícios provenientes do uso do conhecimento tradicional, mas é necessário que isso aconteça o mais rápido possivel. A seguir, serão colocados alguns aspectos que põem em relevo essas dificuldades que, entretanto, podem ser resolvidas:

- a grande maioria das comunidades desconhece totalmente essa questão (ver 2.1 - O Vitae Civilis; VITAE CIVILIS, 1995); é crucial portanto que as comunidades se organizem como pessoa jurídica e compreendam bem seus direitos e deveres nessa situação;

- as comunidades, em sua grande maioria, têm valores e costumes diferentes dos das sociedades industriais; essas diferenças têm de ser contempladas, consideradas e respeitadas, ou seja, a comunidade precisa ser ouvida e precisa ser parte integrante da equipe responsável pelo desenvolvimento de qualquer plano que venha a ser implementado;

- conhecimento tradicional é coletivo e coletivizado, mas isso não deve ser usado para impedir a resolução da questão; deve ser reconhecida como proprietária do conhecimento tradicional a comunidade que forneceu tal conhecimento ao pesquisador de determinada instituição ou empresa, que a selecionou, com base em critérios preestabelecidos, para realizar suas pesquisas etnobotânicas;

- quando há publicação dos dados, eles se tornam públicos;

- a empresa (ou qualquer instituição) não deve repartir seus ganhos, por meio de royalts, apenas com as comunidades que forneceram as informações, mas também com o país de origem e com os pesquisadores e as instituições envolvidas;

- a empresa (ou qualquer instituição) deve começar a repartir seus ganhos durante a realização da pesquisa na comunidade; um exemplo disto é fornecido pelos 
trabalhos comunitários realizados pela Healing Forest Conservancy (organização sem fins lucrativos) criada e mantida pela Shaman Pharmaceutical (CONTE, 1996).

No caso do Brasil, é crucial e urgente o estabelecimento de instrumentos legais que regulem a divisão dos benefícios provenientes do uso comercial do conhecimento tradicional das comunidades brasileiras, incluindo, nesse caso, as comunidades indígenas, caboclas, remanescentes de quilombos etc. No Brasil há os seguintes instrumentos legais:

- Projeto de Lei $\mathrm{n}^{\mathrm{0}}$ 306/95: trata do acesso a recursos biológicos e genéticos em todos os seus aspectos. O capítulo 5 desse projeto de lei trata da proteção do conhecimento de comunidades tradicionais, locais e indígenas. Esse capítulo é o instrumento nacional mais importante para proteger/garantir às comunidades tradicionais e locais sua participação nos benefícios, financeiros ou não, vindos do uso do conhecimento tradicional dessas comunidades.

- Estatuto do Índio: trata do direito de retorno de benefícios para as populações indígenas.

- A Lei de Patentes, Lei Federal $\mathrm{n}^{\mathrm{o}}$ 115/93 - Novo código brasileiro de propriedade industrial também trata desse tema. 


\section{CARACTERIZAÇÃo DA ÁREA}

\subsection{A Mata Atlântica}

Chamada caáetê - a floresta verdadeira, a floresta ilesa - por seus habitantes originais (DEAN, 1998), a Mata Atlântica está entre as florestas tropicais úmidas que cobrem cerca de $10 \%$ da superfície do globo e mantém mais de $50 \%$ de todas as espécies existentes (WILSON, 1985 apud PLOTKIN, 1991). Cerca da metade da área das florestas tropicais está localizada na América Central e na América do Sul; um quinto na África e um quarto na Ásia (MYERS, 1992).

Essas florestas são fonte primária de recursos naturais, de onde são extraídos diversos produtos e onde encontramos valiosos estoques de recursos genéticos. É conhecido no meio científico que as florestas tropicais mantém cerca de 90 mil das 250 mil espécies de fanerógamas identificadas em todo o globo (PRINCIPE, 1991). É provável que as florestas tropicais mantenham um número bem maior de espécies vegetais, pois é estimado que há cerca de 10 milhões de espécies vegetais em todo o planeta Terra. Essa diferença entre os números das espécies estimadas o das que foram identificadas é uma grande evidência de que o meio científico conhece muito pouco da riqueza das florestas tropicais (PRINCIPE, 1991; MYERS, 1992). A ignorância da ciência ocidental sobre a diversidade biológica e genética é muito grande (MYERS, 1992). Segundo BALANDRIN et al. (1985 apud PRINCIPE, 1991), é estimado que não se sabe nada sobre a composição química de mais de $99 \%$ das espécies vegetais encontradas no Brasil. Ainda segundo o relatório da Conservation International (MITTERMEIER et al., 1997 apud BRASIL, 1998), o Brasil é o pais que possui maior biodiversidade e número de espécies endêmicas do mundo.

A megabiodiversidade e o número de espécies endêmicas que ocorrem por país $\mathrm{e}$ região podem explicar por que os trópicos são o foco da perspectiva de descoberta de novas drogas. Como pode ser observado na relação a seguir mostrando o país ou regiões, entre parênteses, o número de espécies endêmicas: Suiça (01); Alemanha (73); Reino Unido (17); México (3.376) e a região Amazônica (25.000 à 30.000) (CUNNINGHAM, 1996). 
A grande riqueza biológica e genética está diretamente relacionada com a grande complexidade ecológica encontrada nas florestas tropicais. Ao mesmo tempo, vários organismos usam outros tipos de organismos, como por exemplo: as árvores usam animais como polinizadores e dispersores de suas sementes. Entretanto, é muito difícil para o meio científico (seguindo as suas regras) visualizar a riqueza e as inter-relações entre plantas e animais além do ambiente físico sem perder a visão de todo o conjunto. Apesar dessa dificuldade, a maioria dos cientistas concorda que há um balanço, ou seja, um equilibrio ecológico nas florestas tropicais. Os cientistas concordam também que o equilíbrio ecológico nessas florestas é muito frágil (MYERS, 1992).

A riqueza das florestas tropicais não está apenas em sua função de manutenção da diversidade biológica e genética, mas está diretamente relacionada à diversidade cultural encontrada entre os povos que nelas vivem e que delas dependem. Além disso, tais florestas têm função fundamental em vários aspectos ambientais, como, por exemplo, na estabilização do clima local e global, na armazenagem de grandes estoques de carbono, na proteção do solo contra processos erosivos, na proteção de reservas hídricas (MYERS, 1992).

Desde o final da Segunda Guerra Mundial, as florestas tropicais vêm sendo degradadas amplamente, de maneira que perdas irreparáveis estão ocorrendo no que se refere às diversas funções dessas florestas. Vários cientistas acreditam que a recuperação de uma área desmatada pode levar mais de mil anos. Isto é, para que uma área desmatada volte a ter todas as características de uma floresta primária, apresentando um equilíbrio ecológico onde se observe o desempenho das funções já mencionadas anteriormente, pode levar mais de mil anos (MYERS, 1992).

A Mata Atlântica, como uma floresta tropical que é, apresenta diversidade biológica, genética e de ecossistemas, grande importância econômica e social, mas também um equilíbrio ecológico frágil além de vários conflitos fundiários, sociais e ambientais. 


\subsubsection{Aspectos físicos e diversidade biológica, genética e cultural}

Há uns 110 milhões de anos, abriu-se uma fissura entre as geomassas africana e sul-americana, deslizando esta para o norte, rumo ao equador - iniciava-se a formação do Oceano Atlântico sul e uma zona biótica distinta (DEAN, 1998).

A Mata Atlântica se caracteriza por aspectos físicos, biológicos, ecológicos e climáticos. Ela ocupa área de latitude e longitude muito variadas, com diferentes altitudes, relevos, tipos de solo e condições climáticas.

De maneira geral, o solo da Mata Atlântica se originou de rochas cristalinas prépaleozóicas (granito, gnaisses etc.) e de rochas sedimentares ou eruptivas (BIGARELLA, 1991). Ainda, segundo esse autor (op. cit.), de maneira geral as formações da Mata Atlântica ocorrem em solos rasos, arenosos, de baixa fertilidade, mas com uma rápida ciclagem de nutrientes em conseqüência da presença de decompositores, das elevadas precipitação e temperatura (BIGARELLA, 1991). O clima é descrito (CÂMARA, 1991) como variável de sub-úmido, com curtas estações secas, no Nordeste, a extremamente úmido em regiões da Serra do Mar. A temperatura média local é $27,5^{\circ} \mathrm{C}$.

As chuvas freqüentes e o tipo de solo propiciam o acúmulo de água no subsolo, o que dá origem a várias nascentes, cujas águas irão formar rios e cachoeiras de porte considerável (GOVERNO DO ESTADO DE SÃO PAULO, 1992). Ressalta-se que a Mata Atlântica recobriu no passado todas as bacias inferiores, dos baixos cursos até as embocaduras dos rios que vertem para o oceano. Sendo assim, em toda a costa brasileira, essas florestas são cortadas por grandes rios, abrangendo ainda a totalidade das bacias dos rios que nascem nas encostas da Serra do Mar ou nos tabuleiros costeiros (MAGNANINI, 1984).

A Mata Atlântica está distribuída em relevo com altitude média de 800 a 900 metros, podendo chegar a 1700 metros (RIZZINI, 1979 apud POR, 1992), e apresenta valores de pluviosidade média anual superiores a $2000 \mathrm{~mm}^{3}$. Apresenta fisionomia alta e densa e grande variedade de formas e ecótopos (GOVERNO DO ESTADO DE SÃO PAULO, 1992).

Podem ser identificadas três formações distintas quanto aos aspectos fisionômicos e florísticos: mata de planícies costeiras, matas de encosta e matas de 
altitude. JOLY et al. (1991) descrevem essas formações com as seguintes características:

- Matas de planície litorânea ou costeira: com extensões no geral limitadas pelas serras, aparecendo logo após a faixa ocupada pelas dunas ou manguezais. Apresenta vegetação densa, com árvores de 10 a 15 metros de altura, copas sobrepostas e considerável riqueza em lianas e epífitas. Nos estratos arbóreo e arbustivos há famílias e gêneros que se destacam. As herbáceas são representadas principalmente por bromélias e pteridófitas. Os locais mais úmidos, durante a época de chuvas, ficam parcialmente encharcados.

- Matas de encosta: com condições contrastantes pela maior umidade relativa do ar e pelo maior índice de precipitação. É uma formação alta, com árvores de até $35 \mathrm{~m}$ de altitude, com dossel irregular decorrente de topografia acidentada e, portanto, com boa penetração de luz. Em seu estrato herbáceo apresenta baixa presença de gramineas, com alta umidade relativa do ar e boa penetração de luz, o que permite $o$ desenvolvimento de uma luxuriante flora epífita (musgos, samambaias, bromélias e orquídeas). Em áreas sob ação antrópica, podem aparecer agrupamentos quase puros de embaúbas (Cecropia sp) e quaresmeiras (Tibouchina sp).

- Matas de altitude: localizadas nas faixas de relevo onde a escarpa atinge altitudes em torno de 1100 metros, apresentam porte baixo (árvores até $8 \mathrm{~m}$ ), presença marcante de liquens e epífitas e com adensamentos de bromélias terrestres como os caraguatás. A presença de neblina é constante.

Esta formação fitogeográfica, a Mata Atlântica, é pouco estudada pelo meio acadêmico. Apesar do pouco conhecimento científico da riqueza, do potencial e da dinâmica dos fragmentos da Mata Atlântica, reconhece-se que tais fragmentos apresentam um quadro de excepcional diversidade biológica e genética assim como elevados índices de endemismo, tanto no que se refere à fauna quanto à flora. Nesta última considera-se que $55 \%$ de espécies arbóreas, $40 \%$ das famílias de espécies nãoarbóreas e cerca de $70 \%$ de palmeiras, bromélias e outras epífitas ocorrem preferencialmente ou apenas na Mata Atlântica (CÂMARA, 1991; JOLY et al., 1991).

As comunidades locais e tradicionais assim como os grupos étnicos (índios e remanescentes de quilombos), que vivem em áreas da Mata Atlântica, detêm grande conhecimento sobre a dinâmica e o uso de vários recursos naturais desse bioma. Esse conhecimento tradicional é muito pouco conhecido pelo meio científico. BORN et al. 
(1989; 1992), estudando plantas medicinais usadas na medicina popular de uma das áreas mais representativas da Mata Atlântica, a Estação ecológica de Juréia-Itatins, observaram que menos de $50 \%$ das cerca de 400 espécies medicinais usadas pela população local tinham sido estudadas no que se refere a aspectos fitoquímicos e ação farmacológica, à luz da ciência ocidental.

A Mata Atlântica apresenta um frágil equilíbrio ecológico. Por isso, 171 das 202 espécies de animais brasileiros considerados em extinção são originárias da Mata Atlântica (LINO, 1992).

A dinâmica vegetal e a sucessão secundária em áreas cobertas pela Mata Atlântica pode ser observada em formações secundárias de Floresta Ombrófila densa, onde coexistem os estágios de sucessão ecológica pioneiro, inicial, médio e avançado de regeneração natural. MANTOVANI (1993) diz que há vários padrões de sucessão, sendo estes dependentes das variações ambientais e dos distúrbios a que a área foi submetida. Este autor (op. cit.) concluiu também que as áreas de vegetação secundária possuem baixa diversidade de espécies e de homogeneidade fisionômica em conseqüência da predominância de espécies associadas aos estágios sucessivos.

Os gêneros e suas respectivas famílias que se distribuem amplamente no processo de sucessão secundária, na região litorânea do Estado de São Paulo, são as que seguem, segundo MANTOVANI (1993): Piptocarpha e Vernonia (Asteraceae), Cecropia (Cecropiaceae), Clethra (Clethraceae), Alchornea, Hieronyma e Pera (Euphorbiaceae), Senna (Leguminosae), Miconia e Tibouchina (Melastomataceae), Rapanea (Myrsinaceae) e Solanum (Solanaceae).

Segundo MANTOVANI (1993), em seus estudos sobre a estrutura e dinâmica da Floresta Atlântica na Juréia, Iguape - SP., as famílias que apresentaram maior número de espécies foram: Annonaceae, Arecaceae, Bignoniaceae, Chrysobalanaceae, Fabaceae, Melastomataceae, Meliaceae, Mimosaceae, Moraceae, Myrtaceae, Rubiaceae, Sapindaceae e Sapotaceae. A família de espécies arbóreas mais características da Mata Atlântica, no litoral sul do Estado de São Paulo, é a Myrtaceae, com importância florística e estrutural. Ainda, segundo este autor (op. cit.), em áreas conservadas da Mata Atlântica, o palmiteiro (Euterpe edulis - Arecaceae) é importante na determinação de sua estrutura.

Segundo MANTOVANI (1993) e ADAMS (1996), os gêneros que apresentaram os maiores números de espécies foram: Ilex (Aquifoliaceae), Tabebuia (Bignoniaceae), 
Licania (Chrysobalanaceae), Machaerium (Fabaceae), Nectandra, Ocotea (Lauraceae), Trichilia (Meliaceae), Mollinedia (Monimiaceae), Ficus (Moraceae), Calyptranthes, Eugenia, Marliera, Myrcia (Myrtaceae), Psychotria (Rubiaceae), Chrysophyllum e Pouteria (Sapotaceae) e Inga (Mimosaceae).

A figura 1 ilustra as áreas florestais remanescentes no domínio da Mata Atlântica, segundo estudos realizados pela Fundação SOS Mata Atlântica, pelo Instituto Nacional de Pesquisas Espaciais e pelo Instituto Socioambiental (LIMA \& CAPOBIANCO, 1997; FUNDAÇÃO SOS MATA ATLÂNTICA et al., 1998).

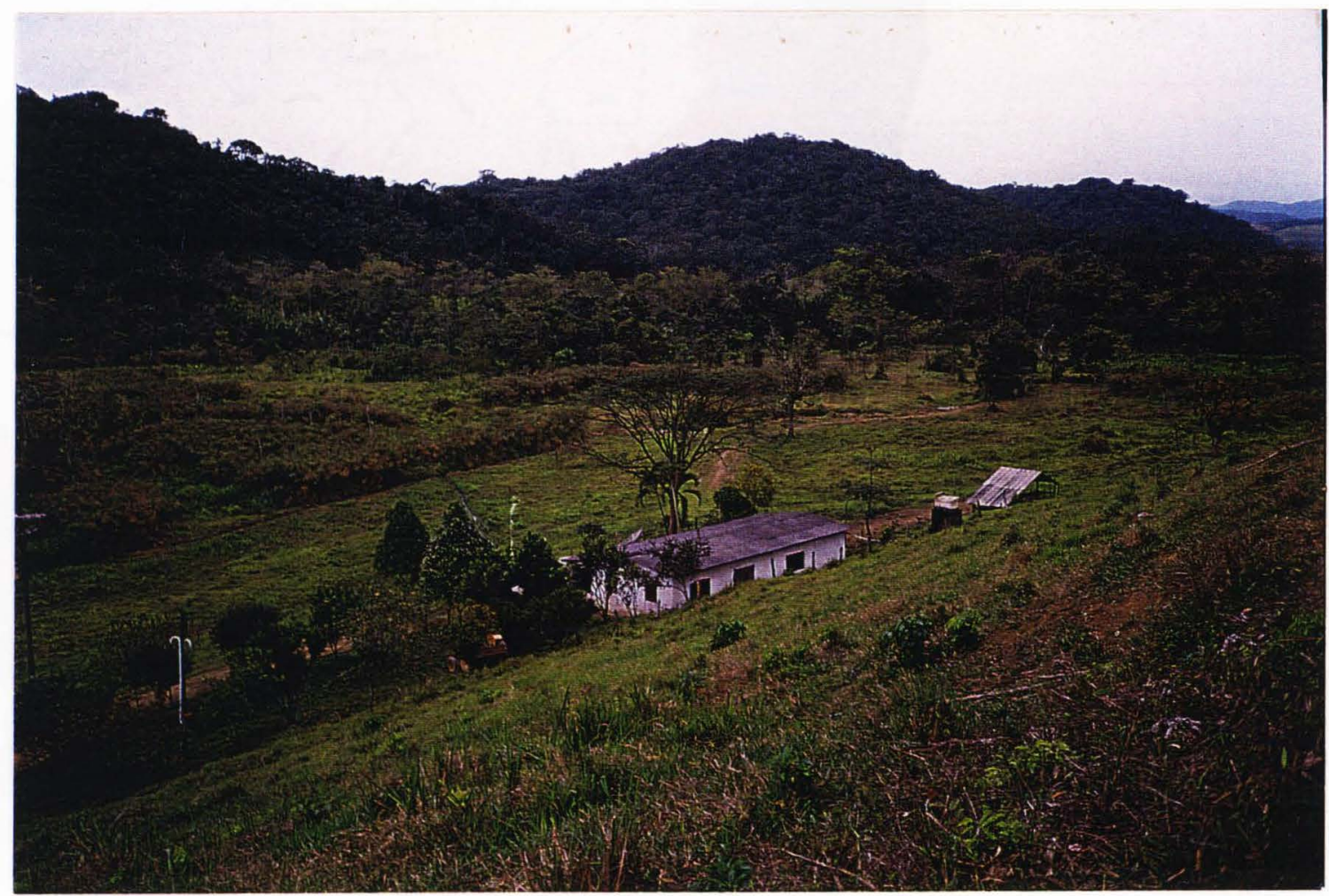

Foto 2. Uma das propriedades onde o Vitae Civilis está realizando estudos sobre o manejo sustentável de espécies medicinais. 


\subsubsection{Aspectos da delimitação e da proteção}

A delimitação da área geográfica da Mata Atlântica tem causado várias polêmicas e vários conflitos sociais, ambientais, jurídicos e econômicos. Têm ocorrido diversos confrontos entre ambientalistas e proprietários de terras localizadas em áreas de domínio da Mata Atlântica, decorrentes das restrições impostas pela legislação vigente e pela cultura predominante.

Para alguns cientistas botânicos e fitogeógrafos, políticos e proprietários de terras, entre outros, a denominação Mata Atlântica deve-se restringir à Floresta Ombrófila Densa que ocorre ao longo do litoral, do Nordeste ao Rio Grande do Sul.

Para outros, representados por membros dessas mesmas categorias, assim como ambientalistas, a denominação Mata Atlântica se baseou na necessidade de defender uma área maior para que possa ser conservada a biodiversidade da Mata Atlântica (GOVERNO DO ESTADO DE SÃO PAULO, 1996). Nesse caso, a área de domínio da Mata Atlântica, ou a Mata Atlântica latu senso, engloba a Floresta Ombrófila Densa, Florestas Estacionais Deciduais e Semideciduais, Florestas Estacionais Semideciduais e Deciduais, Floresta Ombrófila Mista e seus ecossistemas associados (FUNDAÇÃO SOS MATA ATLÂNTICA, 1990; FUNDAÇÃO SOS MATA ATLÂNTICA \& INPE, 1993).

Neste trabalho, serão consideradas as delimitações descritas no Decreto Federal $\mathrm{n}^{\mathrm{0}}$ 750, de 1993 (LIMA \& CAPOBIANCO, 1997), e no Projeto de Lei $\mathrm{n}^{\mathbf{0}} 3.285$, versão de 1999, do Sr. Jaques Wagner e estabelecidas pelo Mapa de Vegetação do Brasil, IBGE 1993, descritas a seguir:

1. a totalidade da Floresta Ombrófila Densa, localizada ao longo do litoral entre os Estados do Rio Grande do Sul e o Rio Grande do Norte, incluindo-se a que recobre a Serra do Mar;

2. a totalidade das Florestas Estacionais Deciduais e Semideciduais dos Estados do Rio Grande do Sul, Santa Catarina, Paraná, São Paulo, Rio de Janeiro, Minas Gerais, Espírito Santo, Bahia e Piaui;

3. as Florestas Estacionais Semideciduais e Deciduais do Estado de Mato Grosso do Sul localizadas nos vales dos rios da margem direita do rio Paraná e da Serra da Bodoquena, do Estado de Goiás localizadas nas margens do Rio Paranaíba e nas 
regiões litorâneas localizadas nos Estados da região Nordeste do país contíguas às Florestas Ombrófilas:

4. a totalidade da Floresta Ombrófila Mista, também denominada Floresta de Araucária, nos Estados do Rio Grande do Sul, Santa Catarina e Paraná, e seus encraves nos Estados de São Paulo, Rio de Janeiro e Minas Gerais, incluindo-se a que recobre a Serra do Mar;

5. os manguezais, a vegetação de restinga, as ilhas litorâneas e demais ecossistemas associados às formações florestais anteriormente descritas;

6. os encraves de savanas, também denominados de cerrados, compreendidos no interior das Florestas Ombrófilas;

7. os encraves de estepes, também denominados de campos, compreendidos no interior das Florestas Ombrófilas;

8. os encraves de campos de altitude, compreendidos no interior das Florestas Ombrófilas;

9. as matas de topo de morro e de encostas do Nordeste, também denominadas brejos e chãs;

10. as formações vegetais nativas dos Arquipélagos de Fernando de Noronha e Trindade;

11. as áreas de tensão ecológica, também denominadas de contatos, entre os tipos de vegetação acima citados.

Há vários atos normativos que tratam, direta ou indiretamente, da proteção da Mata Atlântica. Dentre eles, destacam-se: o artigo 255, do Capitulo do Meio Ambiente da Constituição do Brasil, de 1988, que tornou a Mata Atlântica como patrimônio nacional; o Decreto Federal $\mathrm{n}^{0} 750$, de 1993, e o Projeto de Lei $\mathrm{n}^{\mathrm{Q}} 3.285$, com sua versão original elaborada e apresentada à Câmara Federal, em 1992.

Há discussões calorosas sobre a legalidade do Decreto Federal n0 750/93. Apesar da importância desse decreto, predomina a interpretação de que a regulamentação de um dispositivo constitucional deveria ocorrer sob a forma de lei e não de um decreto (SATO,1995).

Enquanto não há uma lei para regulamentar o artigo 255 da Constituição, o Decreto $750 / 93$ é o ato normativo usado pelo governo como instrumento de fiscalização. 
Esse decreto dispõe sobre o corte, a exploração e a supressão da vegetação primária ou em estágios avançados e médio de regeneração da Mata Atlântica e dá outras providências (SATO, 1995; LIMA \& CAPOBIANCO, 1997).

O Decreto Federal $n^{0} 750 / 93$ diz que a exploração e a comercialização de recursos naturais devem ser feitas com base em planos de manejo sustentado, elaborados a partir de parâmetros científicos, conforme descrito em seu artigo segundo e incisos (VENTURA \& RAMBELLI, 1996):

Artigo 2무 A exploração seletiva de determinadas espécies nativas nas áreas cobertas por vegetação primária ou nos estágios avançados e médio de regeneração da Mata Atlântica poderá ser efetuada desde que observados os seguintes requisitos:

I. não promova a supressão de espécies distintas das autorizadas por meio de práticas de roçadas, bosqueamento e similares;

II. elaboração de projetos, fundamentados, entre outros aspectos, em estudos prévios técnico-cientificos de estoque e de garantia de capacidade de manutenção da espécie;

III. estabelecimento de áreas de retiradas máximas anuais;

IV. prévia autorização do órgão estadual competente, de acordo com as diretrizes e os critérios técnicos por ele estabelecidos.

O parágrafo único deste artigo deixa claro que: Os requisitos deste artigo não se aplicam à exploração eventual de espécies da flora, utilizadas para consumo nas propriedades ou posses das populações tradicionais (...).

\subsubsection{Distribuição original e atual}

A preocupação daqueles que querem conservar as áreas remanescentes da Mata Atlântica é provavelmente explicada pelo uso de suas riquezas ter sido feito de forma indiscriminada, levando à destruição de cerca de $92 \%$ desse bioma, desde sua ocupação humana. Essa preocupação é demonstrada na elaboração e na defesa de atos normativos e também nos conflitos intensos entre aqueles que a querem conservar e aqueles que vivem ou têm propriedades ou posses nessas áreas.

Segundo DEAN (1998), a ocupação da Mata Atlântica ocorreu há cerca de 13 mil anos por caçadores que subitamente invadiram planícies sul-americanas. Ainda, 
segundo esse autor (op.cit.), há evidência de coletores-caçadores na região desse bioma há $11 \mathrm{mil}$ anos. Provavelmente, esses coletores-caçadores já utilizavam fogo para caçar e diminuir a inospitalidade da vegetação da Mata Atlântica. Com o declínio dos grande animais, alguns desses coletores-caçadores se mudaram para a margem das baixadas do continente. Ali eles encontraram pântanos de manguezal e, associadas ao manguezal, ostras. Esses coletores-caçadores começaram a obter sua proteína sem precisar gastar quase nenhuma energia nem usar nenhuma técnica elaborada. Eles coletavam os abundantes moluscos e atiravam as conchas por cima dos ombros. Logo foram se acumulando pilhas enormes de conchas de amêijoas, mariscos, mexilhões e ostras das árvores e da lama, formando assim os sambaquis (DEAN, 1998).

Com a adoção da agricultura, com o uso do fogo e a derrubada de áreas de floresta, a relação dos seres humanos com a floresta foi transformada radicalmente (DEAN, 1998). A técnica era extremamente simples: perto do fim da estação seca, a faixa de mais ou menos um hectare de floresta - chamada macega - era cortada e deixada secar, e por meio de machados retirava-se um anel da casca dos troncos das árvores maiores, ateavam fogo. As chuvas drenavam os nutrientes para o interior do solo neutralizando-o e ao mesmo tempo fertilizando-o. Após a coleta a área era abandonada até a vegetação se recuperar e chegar a determinada altura (DEAN, 1998). Essa técnica é chamada de itinerante ou de coivara e até hoje é praticada por moradores de áreas da Mata Atlântica (VITAE CIVILIS, 1995).

Apesar da agricultura de derrubada e queimada ter sido extremamente redutiva da floresta, antes da chegada dos europeus na costa atlântica brasileira (DEAN, 1998), a história mostra que a destruição da Mata Atlântica se intensificou há 1500 anos. Foi nesse bioma que a história contemporânea brasileira começou e se desenrolou a partir daí.

Os europeus, principalmente portugueses, começaram a extrair recursos naturais renováveis, começando com o pau-brasil (Caesalpinia echinata), e não-renováveis, como pedras preciosas, ouro e diamantes. Em seguida, a Mata Atlântica passou por um processo de derrubada intenso, para o cultivo do café, (Coffea arabica), muito apreciado pelos moradores urbanos da Europa (DEAN, 1998).

A prática usada para plantar cafezais era a derrubada e queimada da floresta. Além dessa prática, o comércio de café induziu o crescimento demográfico, a urbanização, a industrialização e a implantação de ferrovias (DEAN, 1998). Além disso, 
ocorreram também outros fatores para a devastação da Mata Atlântica, como: uso de lenha e carvão, pastos, a especulação de terras e principalmente o imperativo de desenvolvimento a partir dos anos 50, prolongando-se nos anos 70 e durante todo período da ditadura militar (DEAN, 1998).

A história brasileira assim como a ocupação da Mata Atlântica justificam que seja estimado que $50 \%$ da população brasileira vive em áreas de Mata Atlântica (CAPOBIANCO, 1994). Isso provavelmente é mais uma justificativa para os confrontos existentes entre aqueles que defendem a conservação da Mata Atlântica e aqueles que querem usar e explorar áreas desse bioma.

A Mata Atlântica e seus ecossistemas associados se expandiam originalmente em uma área de cerca de 1290000 quilômetros quadrados, ou seja, cerca de $15 \%$ do território brasileiro, espalhados por 17 Estados: Piauí, Ceará, Rio Grande do Norte, Pernambuco, Paraiba, Sergipe, Alagoas, Bahia, Espirito Santo, Minas Gerais, Rio de Janeiro, Mato Grosso, Goiás, São Paulo, Paraná, Santa Catarina e Rio Grande do Sul (FUNDAÇÃO SOS MATA ATLÂNTICA et al., 1998).

A realidade da destruição da Mata Atlântica é assustadora. Quando essa realidade é comparada com a diversidade biológica e cultural dessa mata, podemos ter um grande sentimento de perda irrecuperável. Considerando a Floresta Ombrófila Densa, os estudos indicam que restaram cerca de $8 \%$ da cobertura original da Mata Atlântica. Tais estudos consideraram os fragmentos com a extensão mínima de 400 hectares e chegaram à conclusão de que restam cerca $95000 \mathrm{~km}^{2} \mathrm{da}$ área original da Mata Atlântica (CÂMARA, 1991). As maiores extensões de áreas remanescentes com mais de 400 hectares estão nos Estados de São Paulo, Paraná e Santa Catarina, onde a presença da Serra do Mar dificultou a utilização das áreas desse bioma. Em situação mais prejudicada estão os Estados do Nordeste. A grande maioria desses Estados não possui fragmentos com a área mínima de 400 hectares (CÂMARA, 1991).

Hoje, as áreas de Mata Atlântica remanescentes estão distribuídas esparsamente ao longo da costa brasileira e no interior das regiões Sul e Sudeste, além de importantes fragmentos no sul dos Estados de Goiás e Mato Grosso do Sul e no interior dos Estados do Nordeste (FUNDAÇ̃̃O SOS MATA ATLÂNTICA et al., 1998). 


\subsection{A região do Vale do Ribeira}

É uma região com grande importância para a conservação da Mata Atlântica. Das áreas remanescentes desse bioma, grande parte encontra-se no Vale do Ribeira.

Essa região, entretanto, apresenta grande contraste entre a riqueza e a beleza de seus recursos naturais e ecossistemas e as condições de vida, não tão dignas, da maioria de sua população rural. As condições para se atingir a sustentabilidade do desenvolvimento dessa região são, portanto, desafiadoras. (BORN et al., 1989; VITAE CIVILIS, 1995; BORN et al., 1996).

\subsubsection{Delimitação e aspectos físicos da região do Vale do Ribeira}

A região do Vale do Ribeira está situada entre o Oceano Atlântico e a Serra do Mar ou Serra de Paranapiacaba (designação regional da Serra do Mar) (SILVA et al.,1986), ao sul do Estado de São Paulo e a leste do Estado do Paraná. A maior área da bacia de seu principal rio, Rio Ribeira de Iguape, está localizada no Estado de São Paulo.

A área de extensão da região do Vale do Ribeira e os municípios nela incluídos não são consensos entre os autores consultados.

Segundo SECRETARIA DE COMUNICAÇÃO DO PT-SP (1998), o Vale do Ribeira, em São Paulo, é composto por 15 municípios: Registro, Pariquera-Açu, Jacupiranga, Cananéia, Iguape, Pedro de Toledo, Barra do Turvo, Iporanga, Miracatu, Juquiá, Sete Barras, Eldorado, Itatiri, Ilha Comprida e Cajatí.

Segundo SILVA et al. (1986), a região do Vale do Ribeira situada no Estado de São Paulo, possui uma área de $16327 \mathrm{~km}^{2}$, abrangendo 16 municípios: Cananéia, Iguape, Peruibe, Itariri, Pedro de Toledo, Miracatu, Juquiá, Sete Barras, Registro, Jacupiranga, Eldorado, Pariquera-Açu, Barra do Turvo, Apiaí, Iporanga e Ribeira.

Para LEPSCH et al. (1990) essa região ocupa uma área de $25000 \mathrm{~km}^{2}$, abrangendo 20 municípios do Estado de São Paulo. Esses autores incluíram todos os municípios citados por SILVA et al. (1986), além dos seguintes: Piedade, Ibiúna, Itapecerica da Serra, Tapiraí. 
Segundo GOVERNO DO ESTADO DE SÃO PAULO/ SECRETARIA DO MEIO AMBIENTE (1997), em sua proposta preliminar para a discussão pública sobre o Macrozoneamento do Vale do Ribeira, a região engloba todos os municípios citados por SILVA et al. (op. cit.), e os apresentados a seguir: São Lourenço, Juquitiba, Ilha Comprida, Itaóca, Barra do Chapeú e Itapirapuã Paulista.

A região do Vale do Ribeira pode, ainda, ser dividida em três sub-regiões.

Segundo SILVA et al. (1986), esta região tem as três seguintes sub-regiões, com seus respectivos municípios:

1. Litoral sul: Cananéia, Iguape e Peruíbe;

2. Baixada do Ribeira: Itariri, Pedro de Toledo, Miracatu, Juquiá, Sete Barras, Registro, Jacupiranga, , Eldorado, Pariquera-Açu e

3. Alto do Ribeira: Barra do Turvo, Apiaí, Iporanga e Ribeira.

BICHIR (1995) a divide nas três seguintes sub-regiões, segundo características topográficas:

1. Baixada: constituída pela planicie costeira, com altitudes inferiores a 100 metros, sub-região onde se localiza a maioria dos núcleos urbanos;

2. Escarpa da Serra: formada pelas vertentes das montanhas que delimitam as regiões do Vale do Ribeira e Baixada Santista e que apresentam altitudes de até 1300 metros;

3. Sub-região pré-serrana: situada entre a planície costeira e a Escarpa da Serra.

A figura 2, no anexo 1, apresenta a região do Vale do Ribeira no Estado de São Paulo com os respectivos municípios que a compõem e alguns elementos infraestruturais como: estradas, ferrovias, rodovias, aeroportos etc.

O clima é considerado subtropical úmido, com verões quentes e sem estação seca. A temperatura relativa anual permanece acima de $21{ }^{\circ} \mathrm{C}$ nas partes central e litorânea. $\mathrm{Na}$ serra esta média diminui até $17^{\circ} \mathrm{C}$ ou menos, dependendo da época do ano. As chuvas são abundantes, excedendo a $2000 \mathrm{~mm}^{3}$ na faixa litorânea e atingindo, em alguns vales internos, $4000 \mathrm{~mm}^{3}$ por ano. No interior são encontrados índices mais baixos (SILVA et al., 1986). Segundo esses autores, os declives acentuados associados à grande precipitação promovem a lavagem do solo, tornando-o ácido.

Seu principal rio é o Ribeira de Iguape, que nasce na cadeia montanhosa da 
Serra do Mar, no Estado do Paraná e se expande longitudinalmente no centro da região do Vale do Ribeira. Ele atravessa toda essa região e desemboca no Oceano Atlântico no município de Iguape (SILVA et al., 1986; BICHIR, 1995). O relevo, com altitude média de 800 a 900 metros, está associado à Serra do Mar.

\subsubsection{Aspectos históricos, sociais, econômicos e culturais}

A região do Vale do Ribeira é uma área de povoamento bastante antiga. Seus habitantes apresentavam um acentuado grau de isolamento. $O$ aproveitamento dos cursos dos rios que formam a bacia hidrográfica do Rio Ribeira de Iguape orientou todo o povoamento do Vale do Ribeira.

O Vale do Ribeira permaneceu com sua economia estagnada por muito tempo, até a abertura de estradas, a expansão da rede de comunicação e a maior facilidade de abastecimento, que trouxeram os primeiros sinais de melhoria.

Cananéia, povoada por portugueses, chamada Vila dos Tupis, em 1.531 já contava com cerca de 200 pessoas que se dedicavam à produção de alimentos para sua subsistência e para suprir necessidades das tropas portuguesas (TRIBUNA DO RIBEIRA, 1981 apud MIRABELLI \& VIEIRA, 1992)

Com a descoberta das ricas minas de ouro de Apiaí, Eldorado e Iporanga, localizadas na sub-região do Alto Ribeira, propiciou a formação de vários povoados nas margens do Rio Ribeira de Iguape. A exploração e a comercialização do ouro foram tão prósperas que no século XVII, havia grande movimento no Rio Ribeira de Iguape, em conseqüência do transporte de ouro, mantimentos, ferramentas, familias e notícias (MIRABELLI \& VIEIRA, 1992).

$\mathrm{Na}$ vila de Iguape, hoje cidade de Iguape, localizada próximo à foz do Rio Ribeira de Iguape, foi construído um porto onde ocorriam a entrada e a saída de materiais, pessoas e notícias para a Europa e para outras cidades do Brasil. A grande importância econômica do porto de Iguape era tão significativa que foi inaugurada a Casa da Oficina Real de Fundição de Ouro, a primeira Casa da Moeda do Brasil, hoje Museu Municipal de Iguape (MIRABELLI \& VIEIRA, 1992).

Posteriormente, essa região passou por um período de decadência, quando vários garimpeiros migraram para o Estado de Minas Gerais, após enchentes do Rio Ribeira de 
Iguape que causaram prejuízos para as vilas criadas nas margens desse rio. As enchentes são freqüentes nessa região, as quais têm causado vários problemas na agricultura e nas residências dos ribeirinhos.

Seguido a esse período que marcou a exploração e a comercialização de ouro, veio o plantio de arroz, a partir do século XIX, na sub-região Baixo Ribeira. Com condições propícias, Iguape passou a ser o principal produtor de arroz do Brasil e alcançou grande fama no exterior, pois a maioria dos engenhos brasileiros, responsáveis pela exportação dessa cultura, encontrava-se em Iguape. O sucesso comercial dessa cultura impulsionou a construção naval, a construção de pequenos portos em vários outros municípios da região do Vale do Ribeira, que começaram a produzir e fornecer arroz e outras culturas, como milho, feijão, mandioca, bem como da cana-de-açúcar, que era a matéria-prima da aguardente e da rapadura (MIRABELLI \& VIEIRA, 1992).

Com a prosperidade vinda do ouro e do arroz, a cidade de Iguape conheceu a fama e a riqueza. Possuía jornais, uma escola agrícola (que existe até hoje), um Consulado Francês (que durou até 1905) (MIRABELLI \& VIEIRA, 1992; CAPOBIANCO, 1994). Mas essa prosperidade da cidade de Iguape e conseqüentemente da região do Vale do Ribeira, decaiu com o assoreamento do porto de Iguape. Segundo CAPOBIANCO (op. cit.), esse assoreamento foi decorrente da abertura do Valo Grande, a primeira grande obra hidráulica do país.

No que se refere à população da região, em 1992, havia cerca de 235554 habitantes (SEADE, 1996). Um pouco mais de 50\% dessa população vivia em áreas urbanas. Segundo o NEPO da UNICAMP (1995), a concentração populacional na área rural foi mantida até a década de 1970, quando a população urbana superou a rural, alcançando $55,4 \%$ e $44,6 \%$, respectivamente. Essa situação é encontrada em outras regiões do Brasil e é decorrente da política de desenvolvimento brasileira criada e imposta pelos governos brasileiros com base na expressão positivista "Ordem e Progresso" (DEAN, 1998). Em 1992, a densidade demográfica da região do Vale do Ribeira era de 19,42 habitantes por $\mathrm{km}^{2}$ (SEADE, 1996).

Essa população é composta principalmente por caboclos, resultado da grande miscigenação brasileira entre o negro, o branco e o índio. Encontram-se ainda negros, japoneses e seus descendentes, índios (tupis e guaranis, os primeiros habitantes da região do Vale do Ribeira) e poucos brancos europeus (como portugueses, alemãs etc.).

Os negros escravos vindos da África, durante o período da mineração do ouro, 
conhecidos como quilombolas (por serem provavelmente remanescentes de antigos quilombos), vivem ainda em comunidades tentando manter seus costumes tradicionais (QUEIROZ, 1983) ou em comunidades de caboclos (BORN et al., 1989). Nesse grupo há muitas pessoas com seis dedos o que é resultado desse isolamento e de casamentos dentro do grupo, freqüentemente entre parentes.

Os japoneses que migraram para o Brasil e foram viver na região do Vale do Ribeira tiveram seu assentamento realizado por uma companhia japonesa chamada KKKK (Kaigai S/A Industrial de Além-Mar). Essa companhia garantiu, ao governo brasileiro, a titulação das terras que os japoneses receberam quando migraram (MIRABELLI \& VIEIRA, 1992). Eles vieram para trabalhar na cultura de arroz, pois a cultura do café não recebeu incentivos do governo, já que em outras regiões do Estado a cultura do café era desenvolvida em condições climáticas mais adequadas para essa cultura (DEAN, 1998).

Segundo a região habitada e os costumes tradicionais, as populações da região do Vale do Ribeira recebem denominações diferentes: praianos ou caiçaras (vivem no litoral), capoavas (vivem em regiões serranas) e ribeirinhas (vivem em margens de rio) (QUEIROZ, 1980; SILVA et al., 1986).

Quanto à infra-estrutura e aos tipos de transporte existentes na região do Vale do Ribeira, há a rodovia federal Régis Bittencourt (BR-116), muito conhecida por ser perigosa em conseqüência do intenso trânsito e da falta de sinalização, entre outros. Essa rodovia liga São Paulo a Curitiba. Há também várias rodovias estaduais e municipais e uma rede ferroviária que liga Registro a Santos.

A construção da BR-116 provocou a redefinição da ocupação do território do Vale do Ribeira e promoveu a expansão da circulação de suas mercadorias. Com a especulação imobiliária, ocorreu a formação de grandes latifúndios, a urbanização, a explosão de loteamentos, o êxodo da população rural e a ruptura da unidade socioeconômico-cultural do Vale (SILVA et al., 1986).

A população, especialmente a rural, usa muito os rios e as estradas vicinais. Ela trafega pelos rios em canoas (construídas de diferentes e apropriados tipos de madeiras), barcos com motor (barco de madeira com motor a diesel ou a gasolina), bateiras ou voadeiras (barco geralmente de alumínio com motor a gasolina ou a diesel). As estradas vicinais, que dão acesso aos sítios são precárias, não pavimentadas e mal conservadas. A grande maioria é intransitável na época das chuvas, o que, na região, é muito 
freqüente, principalmente nos primeiros meses do ano. Há comunidades rurais localizadas em lugares de difícil acesso, como as comunidades tradicionais da Estação ecológica de Juréia-Itatins. Algumas são acessadas por trilhas dentro da mata, cruzando rios por dentro da água ou se equilibrando em cima de troncos de árvores que são colocadas pelos próprios moradores ou guardas-parque, contratados pelo governo responsável pela administração da unidade de conservação. Outros meios de transporte usados pelas comunidades são cavalo, bicicleta e carroças à cavalo (BORN et. al., 1989).

A questão fundiária é uma das mais polêmicas, ou a mais polêmica da região. Mesmo que a atividade agrícola seja a mais usada e desenvolvida na região, ela é dificultada em grande parte pela questão fundiária, por causa da ausência de regularização dos títulos públicos. Desse fato decorrem diversos conflitos, desestimulando novos investimentos na área e bloqueando o crescimento da região. A maior parte do território da região do Vale do Ribeira é constituída de terras de domínio indefinido, ou seja, não têm um proprietário judicialmente reconhecido, mas vários posseiros, indivíduos ou famílias residentes ou não na área que se dizem seus donos. Segundo GOVERNO DO ESTADO DE SÃO PAULO/SECRETARIA DO MEIO AMBIENTE (1997), cerca de 40\% das terras do Vale do Ribeira estão nessa situação. Esta secretaria acrescenta que a prioridade atual é reconhecer e regularizar a posse mansa como meio de acesso imediato aos instrumentos de produção rural, permitindo o licenciamento ambiental (op. cit.).

Pelo fato de a região apresentar graves problemas de ocupação de terras relacionados à questão fundiária, além das questões relacionadas à preservação ambiental é necessário abarcar o componente socioambiental uma vez que grande parte dessa região se encontra em áreas de parques, em reservas e em áreas de proteção ambiental (VITAE CIVILIS, 1995).

Os indicadores socioeconômicos mostram que os núcleos e bairros rurais dessa região são quase sempre excluídos de programas de assistência e desenvolvimento do governo do Estado. Esses núcleos e bairros, conseqüentemente, enfrentam sérios problemas, como a falta de documentação de terras, a falta de saneamento básico, a precariedade das vias de transportes e a deficiência no abastecimento e nos serviços públicos (ENGECORPS \& GOVERNO DO ESTADO DE SÃO PAULO, 1992).

A região do Vale do Ribeira apresenta altos índices de mortalidade infantil e de 
analfabetismo. Segundo SILVA et al. (1986), o coeficiente de mortalidade infantil, em 1980, situou-se em 73,7 por mil nascidos vivos (neonatal 33,1 e infantil tardia 40,6) e de mortalidade proporcional em menores de 5 anos e maiores de 50 anos, corresponderam, respectivamente, no ano referido, a $36,32 \%$ e $41,22 \%$. Essa região, segundo BICHIR, (1995), apresenta o segundo maior índice de analfabetismo do Estado. Em 1991, este correspondia a 20,78\%. Esse autor cita também que o coeficiente de mortalidade infantil, em 1992, foi de 28,37 por mil nascidos vivos na região. Mas há municípios como Barra do Turvo, por exemplo, que, no mesmo ano, apresentou o coeficiente de mortalidade infantil de 50,28 por mil nascidos vivos.

A situação habitacional além de ser bastante precária, com crescentes invasões de terras, não se limita à população de baixa renda. Além disso, mais da metade da população regional possui renda menor que dois salários mínimos (BICHIR, 1995).

Essa região também apresenta deficiência no que se refere à saúde pública. Há vários bairros rurais que não possuem tratamento de água. Nesses bairros, a disposição do lixo é a céu-aberto, constituindo-se em reservatórios de animais transmissores de doenças, Além disso, não há latrinas nem fossas sépticas (BORN et al., 1989; VITAE CIVILIS, 1995). SILVA et al. (1986) afirmam que a região é caracterizada pelo aparecimento de doenças endêmicas e epidêmicas, tais como arbovirose, malária, esquistossomose, leishmaniose cutânea-mucosa, tuberculose, hanseníase, doença de Chagas e mordeduras por morcegos hematófagos. Outro problema é a prevalência de desnutrição.

A Secretaria de Estado de Saúde, por intermédio do antigo Escritório Regional de Saúde 49 (ERSA-49), coordena as atividades na região, realizando a supervisão, o treinamento e o apoio supletivo às ações de saúde pública. Para tanto, conta com alguns hospitais, postos de saúde e um laboratório regional do Instituto Adolfo Lutz, em Registro. A infra-estrutura para atender à saúde pública é insuficiente e, em alguns casos, inadequada (SILVA et al., 1986; BICHIR, 1995).

Conforme foi discutido no item 2.1- O Vitae Civilis, destaca- se nessa região o programa chamado DEVALE que cria postos de saúde com agentes comunitários de saúde treinados, em bairros rurais, em parceria com as prefeituras dos municípios. Os moradores do bairro rural têm grande participação na criação do cargo de agente comunitário de saúde e também na escolha da pessoa que o assumirá (SILVA et al., 1986; BORN et al., 1996). 
A economia da região do Vale do Ribeira baseia-se em atividades especialmente agrícolas (cultivo de banana, chá, arroz, frutas, legumes, verduras e mandioca), pesqueiras (além da pesca em rios e no mar, há também criadouros de peixe), extrativistas (madeiras, fibras, palmito, plantas medicinais e ornamentais), além da pecuária, da agricultura e da pesca de subsistência, dos trabalhos assalariados, dos biscates e da mineração.

As culturas que se destacam nas atividades agrícolas são a de banana e ainda a do chá, mas este último está em fase de grande decadência pela falta de estudos sobre a cultura e pelas condições ambientais, sociais e culturais encontradas na região. A bananicultura é realizada em serras e em várzeas com o emprego em larga escala de agrotóxicos e adubos químicos. A mão-de-obra da bananicultura pode vir da família do meieiro (ou seja, aquele que produz e divide a produção com o proprietário do bananal, que detém as condições da venda da produção), de assalariados sem vínculo empregatício, de diaristas, entre outros. As condições dos trabalhadores e de suas familias, inclusive de seus filhos que quase sempre não freqüentam escolas, são muito precárias (SILVA et al., 1986).

A banana produzida pelos pequenos sitiantes é vendida para intermediários. A produção dessa cultura, assim como o foram a do arroz e a do chá, é vendida para o exterior, concorrendo com as produções de outros paises. Essa concorrência foi, e ainda é, muito desigual, porque a produção da região é proveniente principalmente de pequenos sitiantes e é geralmente de baixa qualidade por não contar com tecnologia apropriada, capacitação nem incentivos agrícolas provenientes do governo que contemplem a realidade da região.

Outro grande problema diz respeito ao escoamento da produção devido à falta de infra-estrutura de estradas, à descapitalização dos sitiantes e ao seu despreparo técnico e comercial.

Outra forma de obtenção de renda é com artesanatos e turismo (BORN \& RODRIGUES, 1998). Apesar de a região ter grande potencial turístico devido aos seus atrativos, tais como: ilhas, cavernas, parques, monumentos históricos e religiosos, a infra-estrutura turística permanece precária e insuficiente.

Mais da metade da população economicamente ativa da região do Vale do Ribeira não participa do mercado formal do trabalho (GOVERNO DO ESTADO DE SÃO PAULO/SECRETARIA DO MEIO AMBIENTE, 1997). Além disso, três de cada 
quatro pessoas que participam do mercado formal do trabalho recebem menos de 1,5 salário mínimo por mês (BICHIR, 1995).

Apesar da economia dessa região ter passado por várias modificações e influências do sistema capitalista, bairros rurais realizam atividades agrícolas, e outras, nos moldes da cultura caipira (CANDIDO, 1998), tais como pesca tradicional, extração de madeiras e de fibras, e agricultura de subsistência, praticadas pelos praianos, capoavas e ribeirinhas.

\subsubsection{Aspectos políticos e legais da conservação}

Cerca de $13 \%$ de todas áreas remanescentes de Mata Atlântica existentes em todo o Brasil estão localizados na região do Vale do Ribeira (CAPOBIANCO, 1994). Segundo esse autor (op. cit.), esta porcentagem foi obtida considerando as porções paulistas e paranaenses do Vale do Ribeira no Atlas da Evolução dos Remanescentes Florestais e Ecossistemas Associados do Domínio da Mata Atlântica no Período 198590 (FUNDAÇÃO SOS MATA ATLÂNTICA \& INPE, 1993). É nessa região que se encontra a maior área contínua de florestas e ecossistemas associados característicos da área de domínio da Mata Atlântica do Brasil.

A importância ecológica e cultural da região do Vale do Ribeira para o Estado de São Paulo ampliou-se quando foi estudada a situação de cobertura vegetal desse Estado (VICTOR, 1975 apud GOVERNO DO ESTADO DE SÃO PAULO, 1987). Estimou-se que originalmente $87 \%$ da área do Estado de São Paulo era coberta por florestas. Em 1975, essa área florestal estava reduzida a cerca de 5\% e as estimativas para o ano 2000 são desanimadoras: apenas $3 \%$ da cobertura florestal permanecerá. Quase a metade dos 5\% de cobertura florestal que restaram no Estado de São Paulo está na região do Vale do Ribeira (GOVERNO DO ESTADO DE SÃO PAULO, 1987).

Em conseqüência da grande riqueza encontrada na região do Vale do Ribeira e da importância dessa região para o Estado de São Paulo, assim como da filosofia predominante, que busca formas de conservar e preservar a natureza, aí se encontram grande número e grande extensão de áreas de proteção ambiental ou unidades de conservação. Estima-se que mais de $60 \%$ da área da região do Vale do Ribeira está sujeita à legislação ambiental, que estabelece vários graus de restrições para o uso da 
terra e dos recursos naturais. Cerca de $20 \%$ do território dessa região abrange vários tipos de unidades de conservação (SÃO PAULO STATE. ENVIRONMENT SECRETARIAT, 1997a), que estão sob a administração do governo estadual, ou federal, ou, ainda, sob a administração de ambos.

Entre as áreas de proteção ambiental (ou unidades de conservação), encontramse parques estaduais, estações ecológicas - estaduais e federais-, áreas de proteção ambiental (APA) - estadual e federal —, reserva ecológica estadual, zona de vida selvagem de APA, área de especial interesse científico (ARIE), área sob proteção especial (ASPE) e vilas indígenas. Diferentes tipos de unidades de conservação podem ser encontrados em uma mesma área, por exemplo, APA em área de estações ecológicas e parques; ARIE e ASPE em estações ecológicas. Por exemplo, na área da Estação ecológica de Juréia-Itatins encontram-se APA, ARIE e ASPE (GOVERNO DO ESTADO DE SÃO PAULO/SECRETARIA DO MEIO AMBIENTE, 1997a).

Em grande parte das unidades de conservação, de uso restrito ou não, há famílias morando há várias gerações. Esta situação paulista é semelhante à da América do Sul. Segundo STEPHAN \& AMENDA (1992), dos 184 parques da Venezuela, Bolívia, Equador, Colômbia, Paraguai, Peru, Chile e do Brasil, 85,9\% são ocupados por populações humanas ou usados por estas para obter recursos naturais. Desses parques apenas $29,3 \%$ dispõe de planos de manejo, segundo os autores (op. cit.).

Os atos normativos brasileiros que regularizam o uso de recursos naturais, incluindo o uso da terra, tanto dentro como fora de unidades de conservação, são aplicados a todos os cidadãos.

O capitulo VI, "Do Meio Ambiente”, da Constituição Federal de 1988, elevou o meio ambiente ecologicamente equilibrado à condição de bem de uso comum do povo e essencial à sadia qualidade de vida. O bem de uso comum do povo é aquele bem público cujos usuários são todos os cidadãos, indistintamente, não cabendo a ninguém o uso exclusivo ou o privilégio na utilização do bem (VITAE CIVILIS, 1995).

A Constituição Federal impõe ao Poder Público e à coletividade o dever de defender e preservar o meio ambiente, impondo portanto o direito-dever e incumbindo obrigações para todos: para o poder público, a coletividade e o indivíduo. Reafirma a obrigação que a presente geração tem para com as vindouras.

Infra-constitucionalmente, temos diversas leis que, de conformidade com os princípios constitucionais acima transcritos, regulam e dispõem limites ao uso dos 
recursos naturais. Dentre essas leis gerais, estão destacadas abaixo as que regulam atividades que, de alguma forma, atingem as comunidades locais e tradicionais que vivem em áreas com florestas.

O Código Florestal (Lei Federal n 4.771/65) limita o exercicio do direito da propriedade de florestas, prevendo a proteção do solo e dos cursos d'água assim como promove a conservação da biodiversidade. Para tanto, obriga a criação das áreas de preservação permanente em margens dos cursos d'água, das lagoas, das nascentes, dos olhos d'água, em topos de morro, em encostas com declividade superior a $45^{\circ}$, em bordas de chapada e vegetação em altitudes superiores a 1800 metros. Subordinou a exploração de recursos vegetais à licença emitida pelo órgão público competente. Criou a reserva legal obrigatória, que é a área mínima de vegetação que deve ser preservada dentro de uma propriedade rural (VENTURA \& RAMBELLI, 1996).

É importante ressaltar ainda que, embora a Constituição trate o meio ambiente como bem de uso comum e qualifique a Mata Atlântica, a Amazônia e outros ecossistemas também importantes como patrimônio nacional, de acordo com o sistema jurídico brasileiro, os recursos florestais são de propriedade do titular das terras de onde provêm, ou melhor, são concebidos como acessórios do solo. Assim sendo, cabe a esse titular o direito de explorá-los em seu benefício, de acordo com o consagrado direito constitucional da propriedade privada (VITAE CIVILIS, 1995).

O Código de Caça (Lei Federal nº 5.197/67) proibiu a utilização, perseguição, destruição, caça ou captura dos animais de quaisquer espécies, em qualquer fase de seu desenvolvimento, que vivam naturalmente fora de cativeiro, constituindo a fauna silvestre, bem como seus ninhos, abrigos e criadouros naturais, propriedade do Estado (VENTURA \& RAMBELLI, 1996).

Mas há exceções: o Ibama pode autorizar a caça em reservas indígenas no território nacional, exceto no Estado de São Paulo. A Constituição desse Estado, de 1989, em seu artigo 204, proibiu expressamente, sob qualquer pretexto, a caça em todo território estadual.

O Código de Pesca (Decreto Lei $\mathrm{n}^{\mathrm{o}}$ 221/67) dispõe regras sobre a prática da pesca. Declara que são de domínio público os animais e vegetais encontrados em águas públicas. Esse código estabelece uma série de restrições ao uso de instrumentos e métodos de pesca, prevê a possibilidade de interditar a pesca, transitória ou definitivamente, em águas de domínio público ou privado, nas épocas e nos locais em 
que o órgão competente (Ibama) entender como pertinente. Encontram-se várias leis regulamentando a pesca de animais específicos (VENTURA \& RAMBELLI, 1996).

As unidades de conservação, tanto de uso restrito como as de uso não restrito, assim como suas populações humanas estão sujeitas às leis comentadas anteriormente e aos atos normativos da respectiva área protegida. Por exemplo, a Lei Federal $\mathrm{n}^{\circ}$ 6.902, de 1981, instituiu a criação da estação ecológica como sendo uma categoria de unidade de conservação destinada à realização de pesquisas básicas e aplicadas de ecologia, à proteção do ambiente natural e ao desenvolvimento da educação ambiental. Trata-se de um bem público de uso especial, o que significa dizer que, a não ser por disposição legal em contrário, tal bem não pode ser utilizado para nenhum outro fim que não sejam os mencionados acima (VITAE CIVILIS, 1995). Noventa (90) por cento ou mais de sua área é destinada à preservação integral da bióta e na área restante podem-se realizar as pesquisas ecológicas referidas acima.

No Brasil, desde 1992, vêm ocorrendo várias reuniões, encontros e debates, visando a criação e a sistematização de uma política única para unidades de conservação, que defina o papel das categorias de áreas protegidas e preveja a necessidade de criação de novas categorias, objetivando harmonizar distintos interesses e necessidades de conservação, que incluem a proteção da biodiversidade, do conhecimento e da cultura das comunidades tradicionais e locais.

As categorias de unidades de conservação foram classificadas nos dois grandes grupos, listados abaixo:

- Unidades de Proteção Integral: objetiva preservar a natureza; a visitação do público pode ser proibida ou está condicionada ao plano de manejo da unidade; permite a realização de pesquisas. Inclui os seguintes tipos de unidades de conservação: estações ecológicas, parques nacionais, monumentos naturais, reservas biológicas e refúgios de vida silvestre;

- Unidades de Uso Sustentável: objetiva basicamente promover e assegurar o uso sustentável dos seus recursos naturais, permitindo a moradia de populações humanas em seu interior. Inclui os seguintes tipos de unidades de conservação: reservas de fauna, áreas de proteção ambiental, florestas nacionais, reservas extrativistas; reserva do patrimônio natural, reserva de desenvolvimento sustentável, ária de relevante interesse ecológico. 


\section{EXTRATIVISMO E COMERCIALIZAÇÃO DE PLANTAS MEDICINAIS NO VALE DO RIBEIRA}

\subsection{O levantamento etnobotânico}

A pesquisa etnobotânica foi utilizada como instrumento para levantar, entender e documentar o conhecimento tradicional ${ }^{8}$ de uma amostra dos extratores e produtores de plantas medicinais da região do Vale do Ribeira, Estado de São Paulo, considerado como grupo de estudo dessa pesquisa. Conforme será descrito, a seguir, esse conhecimento tradicional foi observado no que se refere a métodos de identificação, extração, transporte, beneficiamento e comercialização de plantas medicinais que ocorrem espontaneamente em áreas de Mata Atlântica. Foram levantados também aspectos sociais, econômicos e políticos do grupo de estudo, assim como sua relação com a natureza, com os órgãos governamentais responsáveis pela fiscalização dos recursos naturais renováveis (Ibama e DEPRN) e com a Aepam, no que se refere ao contexto da prática de extração de plantas medicinais e de sua conservação, teve por finalidades verificar e avaliar o uso de tais plantas como um dos instrumentos para obter a sustentabilidade do desenvolvimento da região do Vale do Ribeira, Estado de São Paulo, e a conservação da Mata Atlântica.

Conforme foi amplamente explicado no item 3.2 (Pesquisa etnobotânica), essa pesquisa foi recentemente reconhecida como uma disciplina científica (ALEXIADES, 1996) que tem como objetivo principal estudar as interações, associações e interrelações entre as sociedades humanas, atuais e passadas, com o meio ambiente, especialmente com os vegetais. Para que esse estudo seja possivel, é necessário haver uma abordagem interdisciplinar (BORN, 1998) e utilizar métodos e técnicas das ciências sociais e naturais, principalmente da Antropologia e da Botânica,

${ }^{8}$ Conhecimento tradicional: o tradicional não significa antigo, mas sim a maneira que ele foi adquirido e é usado; neste caso, conhecimento tradicional pode ser definido como sendo o processo social de aprendizagem e de troca de conhecimento (DUTFIELD, 1999). 
respectivamente.

A abordagem usada para realizar essa pesquisa foi a da pesquisa participante (BRANDÃO, 1984; ver 3.2. Pesquisa etnobotânica). A abordagem, portanto, englobou, principalmente, um compromisso com o grupo em estudo de analisar as questões, repassar tais análises e discuti-las e, por fim, de contribuir com a mobilização e fortalecimento do grupo. A ação dessa pesquisa está sendo realizada no âmbito do Vitae Civilis, ONG sem fins lucrativos (ver 2. O contexto e a gênese da tese). Portanto, os dados dessa pesquisa estão sendo usados por essa ONG para continuar a ação com o grupo em estudo, mais especificamente no que se refere ao apoio à Aepam, a associar o conhecimento tradicional ao da ciência ocidental para obter indicadores ecológicos que serão usados na elaboração de planos de manejo sustentável de espécies medicinais da Mata Atlântica. $\mathrm{O}$ retorno dos dados analisados será usado como uma das formas de capacitar e treinar o grupo em estudo e também outros agentes sociais envolvidos. $\mathrm{O}$ grupo em estudo, representado por sua associação (Aepam), assumiu também compromisso com a pesquisadora e com a instituição Vitae Civilis para a realização da pesquisa, ora apresentada, e de outros trabalhos no âmbito do Projeto Da mata à casa.

Serão usados pseudônimos no final das falas para garantir o anonimato dos entrevistados e os quais serão designados de A, B, C etc..

\subsubsection{A área e a amostragem do universo da pesquisa}

A coleta de dados da pesquisa foi realizada basicamente em dois momentos: um foi em 1995 e outro em 1997. No primeiro período, em 1995, foi realizada também uma pesquisa exploratória que possibilitou a definição do universo de estudo, a área de maior atuação, ou seja, a área onde se podia encontrar maior número de membros do universo de estudo; o entendimento e a definição de termos utilizados pelo universo de estudo, assim como a compreensão dos vários processos incluídos na identificação, extração, transporte, beneficiamento e comercialização de plantas medicinais de Mata Atlântica. A compreensão e o entendimento desses aspectos, assim como os testes realizados, possibilitaram a definição dos instrumentos de pesquisa (CICOUREL, 1980; ver item 5.1.2 - Instrumentos e estratégias dos levantamentos de campo).

O universo dessa pesquisa é constituído pelos extratores e produtores de plantas 
medicinais, que atuam em áreas remanescentes de Mata Atlântica da região do Vale do Ribeira, Estado de São Paulo, mais precisamente nos seguintes municípios: Registro, Eldorado, Sete Barras, Juquiá, Pariquera-açu, Iguape, Ilha Comprida e Cananéia (figura 2, no anexo 1).

Os seguintes conceitos guiaram a formação da amostra do universo da pesquisa:

- Os extratores foram considerados indivíduos ou famílias que extraem plantas medicinais, que ocorrem espontaneamente, em ecossistemas de Mata Atlântica. Podem beneficiar ou não o material vegetal extraído. Podem realizar essas atividades por iniciativa própria, como autônomos, ou estar vinculados a um ou mais produtores da região, na condição de empregados ou outra condição.

- Os produtores foram considerados indivíduos ou famílias responsáveis pelo cultivo, beneficiamento e comercialização de plantas medicinais cultivadas e extraídas. Quando absorvem a produção extrativa de outros extratores podem também ser categorizados como intermediários.

A definição do universo da pesquisa foi realizada com base no conhecimento obtido durante o período de 1993 a 1994, quando foi realizado o primeiro contato e o apoio ao grupo em estudo para criar e fortalecer sua associação (Aepam) e durante a pesquisa exploratória, realizada em 1995. Para a definição de uma amostra representativa deste universo, foi usada a técnica de amostragem denominada snow ball (bola de neve). Essa técnica recomenda a escolha aleatória de membros do universo da pesquisa até que as informações fornecidas por eles se tornem repetitivas (GIL, 1995). Apesar dessa recomendação, a composição da amostra foi definida por indicações dos próprios produtores e extratores, que se destacaram pelo papel de liderança no grupo, e por técnicos de órgãos do governo, como, por exemplo, Casa do Agricultor do Vale do Ribeira, DEPRN e Ibama. Além disso, foram usadas informações obtidas em reuniões da Aepam, assim como as obtidas nos cadastros de extratores de recursos naturais renováveis, fornecidos pelo Ibama e DEPRN, para selecionar aqueles extratores e produtores que só trabalham com plantas medicinais.

Foi decidido fazer a composição da amostra conforme explicado acima, devido às grandes dificuldades em localizar e escolher aleatoriamente extratores e produtores de plantas medicinais na região do Vale do Ribeira para formar a amostra. Essas dificuldades são peculiares a essa pesquisa etnobotânica, pois ela foi realizada com um grupo de indivíduos e famílias que explora e comercializa recursos naturais renováveis 
(como plantas medicinais), para obter ou para complementar seu sustento, em uma região que contém vários conflitos, especialmente fundiários e ambientais (ver itens 2.2 A gênese da Aepam, 2.3 - O projeto Da mata à Casa, 4.2 - A região do Vale do Ribeira).

\subsubsection{Instrumentos e estratégias dos levantamentos de campo}

A pesquisa participante e a observação participante foram os principais métodos usados, em campo, para realizar o levantamento etnobotânico. Usando esses métodos, o pesquisador tem um compromisso com o grupo que ele está estudando (BRANDÃO, 1984) e, também, procura entender as interações existentes entre o ser humano e seu meio. Com esse objetivo, o pesquisador, freqüentemente, acompanha o entrevistado em suas atividades diárias ou naquelas que ele está pesquisando (FOOTE-WHYTE, 1990; MALINOWSKI, 1990; MARTIN, 1995; ALEXIADES, 1996).

A observação participante foi empregada para a obtenção e a melhor compressão das informações fornecidas pelos entrevistados, especialmente aquelas sobre posicionamento e opinião do grupo em estudo no que se refere à exploração e à comercialização de plantas medicinais, conservação dessas plantas, bem como, no que diz respeito à relação entre o grupo e os órgãos governamentais (Ibama, DEPRN e Polícia Florestal) e entre o grupo e a Aepam. Para tanto, alguns entrevistados foram acompanhados durante caminhadas na mata para se observar técnicas de identificação e o manejo tradicional de plantas medicinais, assim como participar deles. Ainda, com o mesmo objetivo, alguns entrevistados foram acompanhados também quando realizavam os processos de triagem, secagem, trituração e embalagem do material de plantas medicinais.

Por fim, a observação participante foi usada para obter e checar dados fornecidos pelos entrevistados no que se refere à sua percepção ${ }^{9}$, ao posicionamento e à opinião em relação à exploração, conservação e comercialização de plantas medicinais, bem como sobre a relação entre o grupo em estudo e os órgãos governamentais (Ibama, DEPRN e Polícia Florestal) e entre o grupo e a Aepam. Isso foi realizado durante encontros

9 Entende-se por percepção como o entrevistado vê e se relaciona com os órgãos governamentais mencionados, Aepam e com a conservação das plantas medicinais. 
informais ou formais (reuniões) da Aepam ou de outras instituições nas quais havia a presença de representantes dos extratores e produtores de plantas medicinais, dos órgãos do governo e da Aepam.

As técnicas empregadas foram as da observação direta participativa e a de entrevistas.

A observação direta participativa é a tomada de informações por meio dos sentidos, principalmente por meio de processos audiovisuais, ou seja, o pesquisador acompanha o entrevistado durante as atividades que estão sendo estudadas; ocasião em que o pesquisador anota informações, faz perguntas, coleta amostras de espécimes e participa das atividades realizadas pelo entrevistado. Durante as anotações, o pesquisador deve discernir o que foi observado do que foi interpretado. É bastante comum que certa carga interpretativa do receptor (pesquisador) seja transferida para as informações por ele levantadas (FOOT-WHYTE,1990; ALEXIADES, 1996, MARTIN, 1995).

A entrevista é um processo dinâmico e de interação entre o entrevistador e os entrevistados, que se influenciam mutuamente, não apenas por meio das palavras pronunciadas, mas também pela inflexão da voz, pelos gestos, pela expressão fisionômica, pelo modo de olhar, pelo modo de sentar, pela aparência e por demais traços pessoais e manifestações de comportamento dependentes dos aspectos sociais e culturais (NOGUEIRA, 1968). O pesquisador procura obter do entrevistado, por meio de estímulos verbais, respostas para reconstituir fenômenos (ABRAMO, 1988). As entrevistas podem ser realizadas em grupo ou individualmente (ALEXIADES, 1996).

Os principais tipos de entrevista usados foram os seguintes:

- Entrevista informal: o pesquisador faz notas durante ou após uma conversa casual sobre o que foi dito e o que foi observado (ALEXIADES, 1996);

- Entrevista semi-estruturada: baseia-se no uso de uma lista de tópicos que devem ser abordados em certa ordem (BERNARD, 1988);

- Entrevista aberta: aquela que permite ao entrevistado responder livremente, usando lógica própria, e emitir opiniões (LAKATOS \& MARCONI, 1995).

- Entrevista fechada ou estruturada: baseia-se no uso de perguntas predeterminadas com respostas também predeterminadas e categorizadas, em forma de questionário, facilitando a sistematização das informações (BERNARD, 1988; LAKATOS \& 
MARCONI, 1995).

Como instrumentos para direcionamento das entrevistas e sistematização das informações obtidas, foram elaborados e testados quatro questionários, denominados fichas, que estão apresentados no anexo 3. Para elaborar tais questionários, tomou-se como base a verificação e a análise de aspectos da sustentabilidade das atividades de extração e comercialização de plantas medicinais na região do Vale do Ribeira, realizadas pelos extratores e produtores dessa região. Em seguida, foram definidos objetivos para elaborar os quatro questionários, visando identificar:

\section{Ficha 1 - Levantamento de aspectos socioeconômico-políticos}

- nome completo e apelido do entrevistado;

- endereço para correspondência;

- endereço do domicílio;

- procedência;

- sexo;

- faixa etária;

- nível de escolaridade;

- nível de conhecimento.

- número de membros da família que dependem dos rendimentos provenientes da comercialização de plantas medicinais;

- rendimento financeiro mensal da família;

- categoria de atividade em relação a exploração e comercialização de plantas medicinais;

- outras formas de rendimento, se o entrevistado as tiver;

- quantidade de material vegetal fresco extraído e comercializado por mês;

- percepção do entrevistado em relação à Polícia Florestal, ao Ibama e ao DEPRN;

- percepção do entrevistado em relação à Aepam;

- percepção do entrevistado em relação à conservação das plantas medicinais.

Ficha 2 - Técnicas de manejo tradicional, incluindo aspectos da planta e da área utilizada para a extração:

- nome da planta extraída;

- partes extraídas da planta;

- forma de extração (pergunta aberta e fechada/categorizada);

- quantidade média extraída;

- caracteristicas observadas na planta para realizar a extração; 
- época de extração (período do dia e do ano);

- áreas usadas para a extração da planta;

- potencial da planta nas áreas de extração;

- periodicidade da extração, em relação à área;

- características consideradas pelo entrevistado para a escolha de uma área para a extração de determinada planta;

- periodicidade da extração em relação à planta ou à sua população;

- se o material extraído é organizado para o transporte; se sim, identificar a forma e tipo de transporte.

Ficha 3 - Beneficiamento, controle de qualidade e aspectos de comercialização das plantas:

- nome da planta;

- parte extraída da planta;

- se o material vegetal é comercializado fresco ou seco;

- se o entrevistado realiza triagem (limpeza, separação das impurezas) do material extraído;

- procedimento para realizar triagem, secagem, trituração, embalagem e armazenagem.

- se o entrevistado faz algum controle de qualidade no material a ser comercializado; se sim, identificar o procedimento usado;

- faixas de rendimentos da planta - relação entre peso úmido do material extraido e peso seco do produto final;

- faixas de rendimentos obtidos com a comercialização do material vegetal;

- compradores do material vegetal.

Além desse tipo de registro, foram registradas também informações pormenorizadas em anotações no caderno de campo ou mesmo nas próprias fichas. Tais informações foram obtidas em entrevistas e também em observações diretas durante o convívio com os extratores e produtores em seus locais de trabalho. Foram elaboradas etnografias relatando o observado nas atividades participadas e as interpretações realizadas.

O registro dessa pesquisa ocorreu também por meio do uso de gravador, câmaras de vídeo e de fotografia, nas ocasiões em que o entrevistado autorizava. 


\subsubsection{Coleta de material vegetal e identificação botânica}

Foram coletadas cerca de cinco amostras de todas as plantas citadas e identificadas por cada entrevistado, visando a identificação botânica em nível de espécie.

Para registrar e sistematizar as informações referentes à identificação botânica, à morfologia, à ecologia e à origem das plantas medicinais citadas e coletadas, foi usada a Ficha de Coleta (anexo 3). Nessa ficha, encontram-se informações fornecidas pelo entrevistado, conseguidas em observações feitas durante as coletas das amostras, informações obtidas minuciosamente durante o processo da identificação vegetal e também as informações levantadas na bibliografia específica quanto à origem das espécies identificadas.

A coleta desse material vegetal foi realizada segundo métodos e técnicas da Botânica Sistemática. Para tanto, as amostras foram coletadas, quando possivel, com estrutura floral ou com frutos. As amostras foram acondicionadas em campo pelo Método Molhado. Segundo MORI (1985 apud ALEXIADES, 1996), nesse método as amostras vegetais coletadas são distendidas e empacotadas em papel jornal, embebidas em álcool diluído a $70 \%$ e acondicionadas em sacos plásticos, hermeticamente fechados. Este método foi empregado porque otimiza a tolerância do tempo de armazenagem do material vegetal em campo sem que haja comprometimento decorrente do ataque de fungos, por exemplo. Isso permitiu maior permanência em campo, coletando dados e materiais vegetais, sem a necessidade de secagem prévia do material vegetal coletado.

Posteriormente, no Instituto de Botânica do Estado de São Paulo, essas amostras foram submetidas a um processo de secagem de 3 a 5 dias em estufa a $60^{\circ} \mathrm{C}$, para serem herborizadas, conforme a metodologia internacionalmente aceita.

Para a identificação botânica das amostras coletadas, foi feito uma préidentificação no Instituto de Botânica, comparando-as com a coleção de exsicatas de plantas coletadas durante o estudo etnobotânico e etnofarmacológico realizado junto às comunidades tradicionais da Estação ecológica de Juréia-Itatins (BORN et al., 1989) (ver 2.1. O Vitae Civilis). Após essa pré-identificação, as amostras foram levadas a especialistas para que houvesse a conclusão da identificação botânica da amostra.

O material vegetal identificado foi depositado nos herbários do Instituto de 
Botânica do Estado de São Paulo e no do Vitae Civilis na forma de exsicatas (foto 4) confeccionadas segundo padrões internacionais para medidas e material. As medidas internacionais das exsicatas para armazenamento de material botânico são $28 \times 42 \mathrm{~cm}$ e o material padrão é o papel cartolina $80 \mathrm{~kg}$; as capas de papel pardo ou kraft $45 \mathrm{~kg}$. (ALEXIADES, 1996).

A foto 3 mostra um extrator de plantas medicinais participando no processo de herborização das amostras coletadas.

\subsubsection{Instrumentos e estratégias dos levantamentos bibliográficos}

Foram realizados levantamentos em bibliografias especializadas, com as espécies identificadas, para se obter:

- a origem das espécies vegetais citadas pelos extratores e produtores de plantas medicinais e

- estudos científicos sobre a ação farmacológica e propriedade fitoquímica das espécies medicinais levantadas.

Para saber a origem das espécies, foram consultadas as seguintes bibliografias, entre outras: HOOKER \& JACKSON, 1895; PIO CORRÊA, 1974; LORENZI, 1992; BREMNESS, 1994; RODRIGUES, 1989; VIEIRA, 1992; ALBUQUERQUE 1980 e SILVA et al., 1977.

Para levantar ${ }^{2}$ estudos realizados sobre ação farmacológica e propriedade fitoquímica com as espécies medicinais citadas e identificadas pelo grupo em estudo, foi usado o Chemical Abstracts no período de 33 anos, ou seja, de 1966 a 1999. Essas informações foram também cadastradas e sistematizadas em um banco de dados, conforme mostra a ficha de levantamento bibliográfico (anexo 3).

\subsubsection{Organização, análise e interpretação dos dados}

Para organização e interpretação dos dados obtidos nos levantamentos, todas as informações registradas nos questionários (fichas), foram cadastradas em um banco de 
dados, programado para essa pesquisa e com base em BORN \& FÁVERO (1994).

Para os relatórios, foram selecionadas algumas informações dos questionários que permitiram quantificar um padrão de procedimento entre os extratores e produtores. Para facilitar a elaboração de tais padrões, assim como a organização e a análise dos dados, a maioria das questões dos questionários foi categorizada.

Vários padrões (ou categorias) foram estabelecidos a partir de interpretações realizadas para as informações fornecidas pelos entrevistados, que foram analisados durante o teste dos questionários.

A partir do banco de dados, foram elaborados relatórios, tabelas e gráficos demonstrativos, e correlações entre categorias de uma mesma ficha ou de fichas diferentes no que se refere à sustentabilidade do desenvolvimento e à conservação da Mata Atlântica.

Além da análise quantitativa simples, ou seja, que inclui quantidade, média e porcentagens de várias categorias, foi realizada também a análise qualitativa das informações obtidas em todos os tipos de entrevistas, ou seja, entrevista informal, semiestruturada, aberta, fechada ou estruturada. Porém foram usadas mais as informações obtidas nas entrevistas informais, abertas e semi-estruturadas, bem como as da observação participante. Ambas as análises, quantitativa e qualitativa, foram utilizadas com um caráter de complementaridade. 


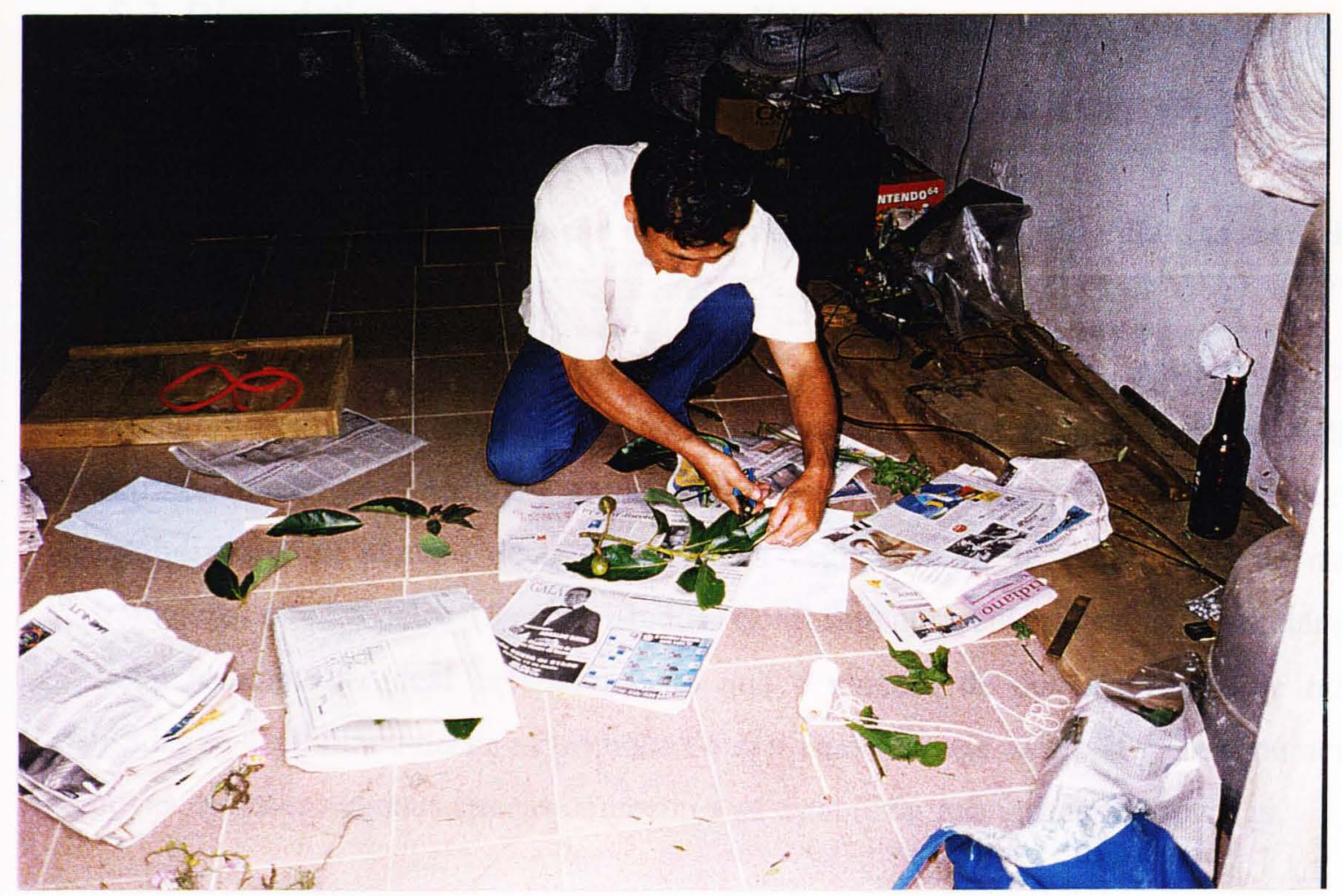

Foto 3. Extrator participando no processo de herborização das amostras das plantas coletadas.

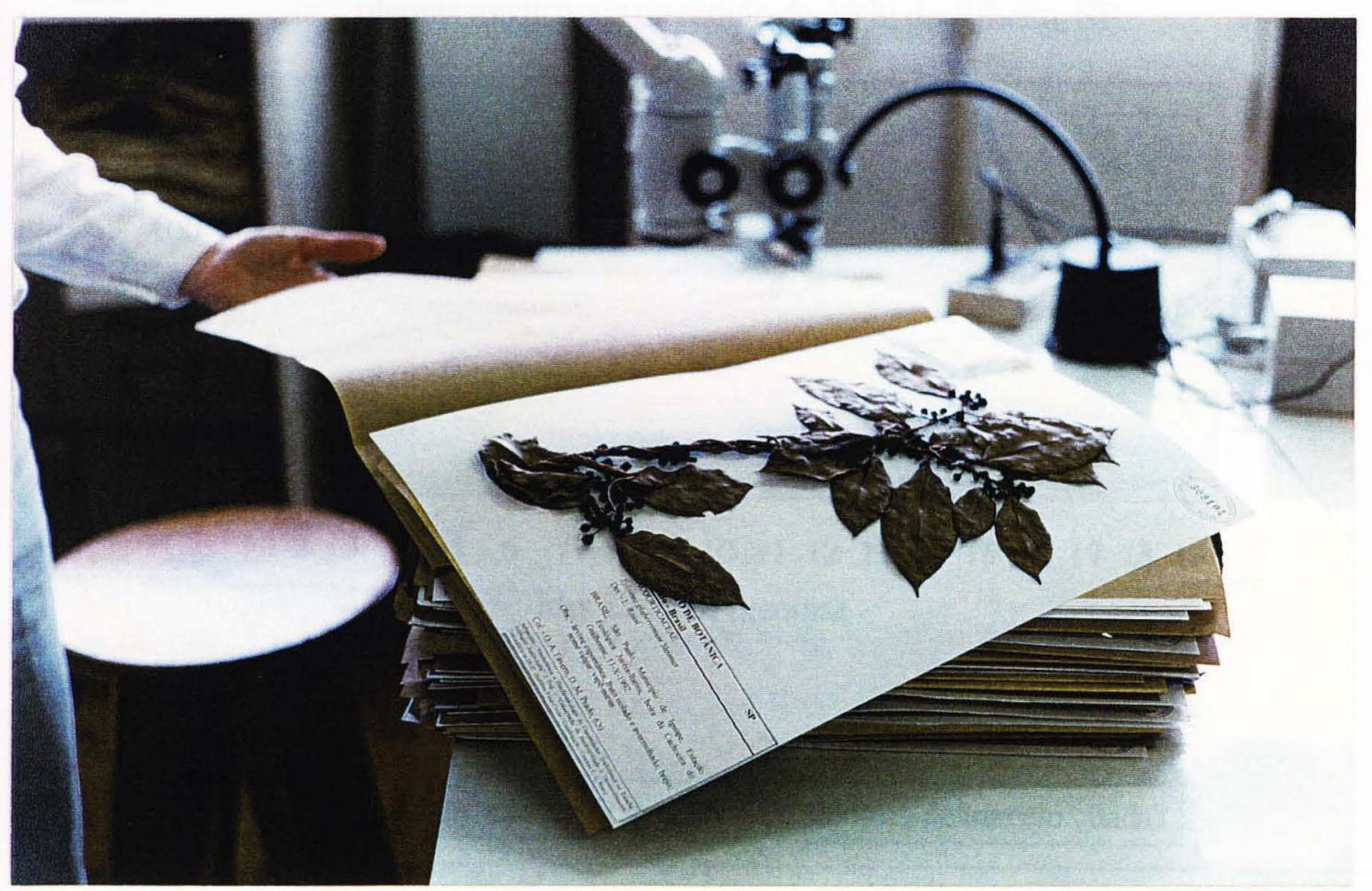

Foto 4. Modelo de exsicata para a identificação da planta e posterior inclusão nos herbários do Vitae Civilis e do Instituto Botânico do Estado de São Paulo. 


\subsection{Diagnóstico socioeconômico-político da amostra}

\subsubsection{A amostra e a distribuição dos extratores e produtores de plantas medicinais}

A amostra desta pesquisa foi composta por 5 extratores e 11 produtores/extratores (quando a mesma pessoa ou família se inclui na definição de extrator e de produtor). A amostra foi considerada completa quando houve a estabilização do número de novas espécies vegetais e de técnicas novas de manejo tradicional citadas pelos 16 entrevistados. Conforme apresenta o gráfico 1, esta amostra ficou próxima do ideal esperado, visto que o número de novas técnicas de manejo usadas se estabilizou desde as primeiras entrevistas, ou seja desde 1995, e o número de novas espécies vegetais citadas começou a se estabilizar nas últimas entrevistas.

Gráfico 1 - Verificação da amostragem dos extratores e produtores de plantas medicinais da região do Vale do Ribeira, SP.

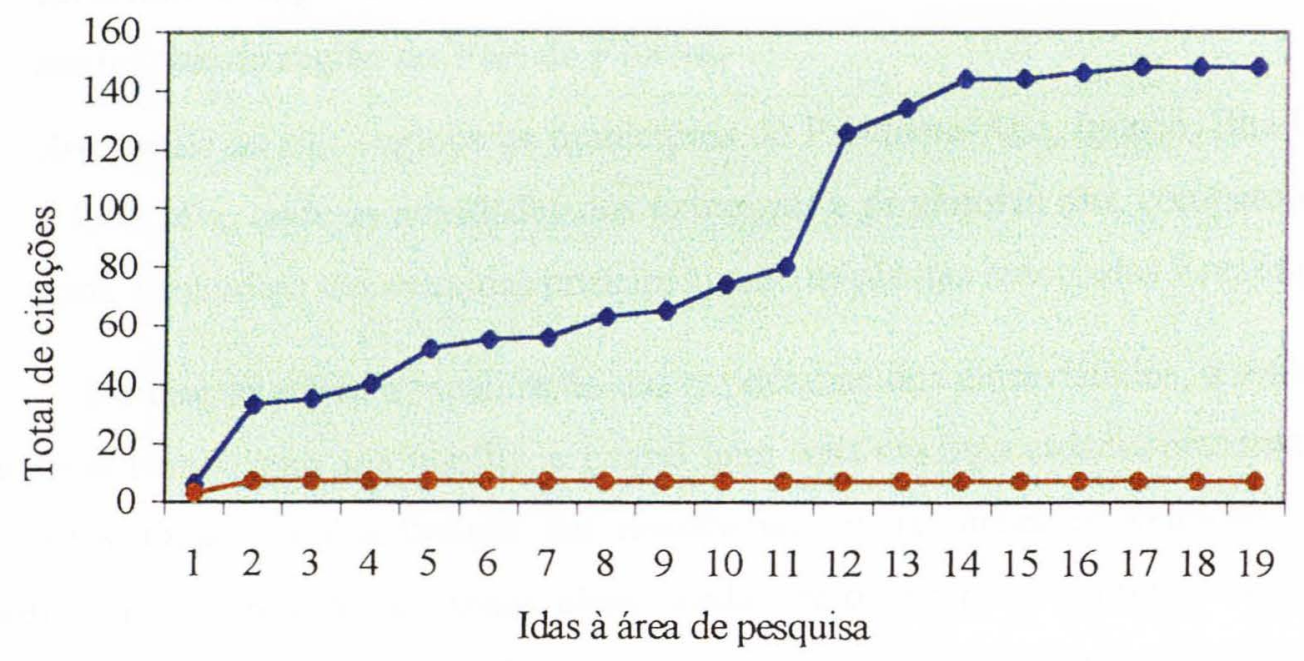


Se se considerarem todas as indicações fornecidas pelas lideranças dos extratores e produtores de plantas medicinais da região do Vale do Ribeira, contidos nos cadastros dos extratores, produtores e comerciantes de plantas de Mata Atlântica do Ibama e do DEPRN, assim como todas as informações obtidas durante as reuniões da Aepam realizadas no periodo de 1993 à 1998, todas as pessoas e famílias que extraem, produzem e comercializam plantas medicinais da Mata Atlântica na região do Vale do Ribeira, Estado de São Paulo, foram contatadas e entrevistadas.

Segundo informações obtidas com os produtores e extratores entrevistados, bem como, com técnicos do Escritório Regional do Ibama de Iguape, a população desta pesquisa reside em municípios localizados em três áreas da região do Vale do Ribeira. Saliento que a classificação das áreas e a distribuição dos municípios, abaixo mencionados (ver figura 3, no item 5.3.2. - As áreas do manejo tradicional), são as utilizadas por extratores e produtores de plantas medicinais entrevistados e pelos técnicos já mencionados:

- Área central: engloba o município de Registro, onde está a maioria dos extratores e produtores de plantas medicinais da região do Vale do Ribeira;

- Area mais ao norte: engloba os municípios de Eldorado, Sete Barras e Juquiá, que apresenta a segunda maior concentração de extratores e produtores de plantas medicinais da região do Vale do Ribeira;

- Area mais ao sul: engloba os municípios de Pariquera-Açu, Iguape, Ilha Comprida e Cananéia, onde as atividades dos extratores e produtores são, comparativamente, mais reduzidas; são extraidas principalmente as plantas associadas à restinga.

No que se refere à localização das residências dos entrevistados, a maioria mora em áreas rurais, com sua família, e possui uma casa em uma cidade, próxima ou não a seu sítio. Quanto à distribuição das residências ou das áreas de extração de plantas medicinais em relação às zonas classificadas pelos próprios entrevistados, descritas acima, observa-se o seguinte: 7 entrevistados estão na área central, 6 na área mais ao norte e 3 na área mais ao sul. Estes extratores e produtores são procedentes de regiões do sudeste, do sul e do nordeste brasileiro, constituindo, respectivamente, $66,7 \%, 22,2 \%$ e $11,1 \%$ dos entrevistados. Dos $66,7 \%$ procedentes da região sudeste, $16,7 \%$ procedem de outros municípios da região do Vale do Ribeira. 
A figura 2, no anexo 1, apresenta a localização das regiões e dos municípios mencionados, na região do Vale do Ribeira, do Estado de São Paulo.

\subsubsection{Caracterização da amostra}

Todos os entrevistados são do sexo masculino e estão distribuídos segundo as faixas etárias a seguir, entre parênteses está a porcentagem: 20 a 30 anos (22,1\%), 40 a 50 anos $(44,5 \%)$ e 50 a 60 anos $(33,4 \%)$. Foram encontradas poucas mulheres desenvolvendo as atividades de extração e comercialização e ao quais desenvolviam tais atividades sob orientações dos homens entrevistados.

O nível de escolaridade e o de conhecimento dos entrevistados são bem variados. Há extratores e produtores de plantas medicinais com curso superior completo, segundo grau incompleto, ginásio incompleto, primário completo (cada um com cerca de $11 \%$ da amostra). A maioria dos entrevistados, entretanto (cerca de $35 \%$ ), informou ter apenas o primário incompleto ${ }^{1}$. Houve, ainda, entrevistados que não forneceram essa informação e estes representaram cerca de $21 \%$ da amostra.

A amostra dos extratores e produtores de plantas medicinais inclui pessoas que trabalham com a extração, produção e comercialização dessas plantas desde há menos de um ano até há mais de dez. As faixas referentes aos períodos de tempo nessas áreas de trabalho e suas respectivas porcentagens são as seguintes: 0 e 2 anos $(11,1 \%) ; 2$ e 4 anos (22,2\%), 4 e 6 anos (33,3\%); 6 e 8 anos (11,1\%); mais de 10 anos de trabalho $(22,3 \%)$.

A renda familiar foi informada por $44,5 \%$ dos entrevistados. Destes, apenas $33,5 \%$ dependem exclusivamente da extração, do cultivo e da comercialização de plantas medicinais para obter a renda de sua familia. Ainda segundo os entrevistados, cerca de 40 pessoas empregam famílias e aproximadamente $50 \%$ dos membros dessas famílias dependem exclusivamente da extração e comercialização de plantas medicinais para obter seu sustento. A renda familiar informada variou de $\mathrm{R} \$ 300,00$ a $\mathrm{R} \$ 2.000,00^{2}$

\footnotetext{
${ }^{\mathrm{l}} \mathrm{O}$ primário, neste caso, eqüivale ao ensino fundamental (da $1^{\mathrm{a}}$ à $4^{\mathrm{a}}$ série).

${ }^{2} \mathrm{R} \$ 300,00$ e R\$ $2.000,00$ eqüivalem em dólares americanos, respectivamente, a US\$270,00 e
} 
por mês.

A maior parte dos entrevistados, que informou a renda familiar (44,5\% dos entrevistados), desenvolve outras atividades além da extração, do cultivo e da comercialização de plantas medicinais. Essas pessoas utilizam a prática de culturas de subsistência, tais como cultivo de arroz, mandioca e feijão, bem como, a criação de animais domésticos, como galinhas e porcos, para completar o sustento de suas famílias. Os entrevistados informaram, também, que podem incrementar a renda familiar por meio do cultivo de chá (mate e preto) e de banana, bem como por meio do extrativismo de produtos florestais, como o látex e o palmito. A comercialização dos produtos obtidos a partir do cultivo e da extração, geralmente, é realizada no mercado local, de acordo com os entrevistados.

Assim, segundo os entrevistados, a maioria da amostra não possui renda familiar apoiada na comercialização de plantas medicinais obtidas pelo extrativismo ou pelo cultivo. Sua principal fonte de renda é a prestação de serviços, como mão-de-obra assalariada ou autônoma, em atividades agropastoris ou comerciais (vendas, mercados, etc.).

\subsubsection{Aspectos dos guias principais}

Entre os entrevistados, destacaram-se três extratores/produtores que serão referidos como guias principais desta pesquisa. $O$ termo guia principal tem, neste caso, o mesmo significado de informante chave, segundo descrição realizada por FOOTWHITE (1980): "Alguns dos informantes, durante uma pesquisa etnocientifica, por deterem algum tipo de poder hierárquico ou exercerem um papel social relevante, costumam ser possuidores de conhecimento mais refinado, a ponto de podermos obter inclusive sugestões que levem a estabelecer um planejamento diferente das atividades da pesquisa, são os chamados informantes chaves.".

Esses entrevistados se destacaram pelas seguintes particularidades: um deles

US\$ $1.801,00$. 
recebeu do avó o conhecimento e a sabedoria de extrair, cultivar e comercializar plantas medicinais; os outros dois possuem estrutura de beneficiamento semelhante, provavelmente as mais bem equipadas da região, com a preocupação de manter a qualidade do produto. Esses dois últimos têm mercado próprio, ou seja, têm seus compradores certos e vendem por preços melhores. O primeiro reside na área mais ao norte, o segundo na área ao sul e o terceiro na área central.

O primeiro guia principal é filho de uma família que tem tradição nas atividades de extração, cultivo, beneficiamento e comercialização de plantas medicinais. Ele gosta de sua condição, deixando bem claro que o seu avó já desenvolvia tais atividades quando alguém se refere à necessidade de conservar a Mata Atlântica:

"Meu avô trabalhava com isto (referia-se à extração, ao cultivo e à comercialização de plantas medicinais); meu pai trabalhou a vida toda! E as plantas continuam todas ai!" (Sr. A).

O segundo guia principal mantém uma empresa familiar há 15 anos. Comercializa para todo o Brasil, sobretudo para a capital paulista. Deseja vender para o mercado exterior, por exemplo, para o Japão. Trabalha com plantas cultivadas sem o uso de agrotóxicos, de acordo com suas informações, mas trabalha também com extração de material vegetal da região da Mata Atlântica, assim como com o de outras regiões do Brasil, como a Amazônia. Trabalha ainda com produtos exóticos, como o ginseng.

Apresenta preocupações com a qualidade do material vegetal e com sua apresentação. Segundo suas informações, ele seca o material no sol matutino e também à sombra, pois acredita que "a planta perde os princípios ativos com a temperatura"; por isso não faz uso de fornos. Seu material à venda apresenta etiqueta com logomarca, nome popular, nome científico, data da colheita, peso, parte da planta, modo de preparo e indicações, além dos números de registro no Ibama e no DEPRN.

Conhece muito pouco a Aepam e tem a seguinte percepção e opinião sobre essa associação e alguns de seus membros: 
"Eles falam mal do material da gente sem conhecer. Eles sim, que têm um material ruim. Eles compram de atacadista do ... (mencionou um dos bairros da cidade de São Paulo), onde tem rato e barata, $e$ revende para laboratórios." (Sr. B)

O terceiro guia principal forneceu uma quantidade maior de dados para esta pesquisa. As informações obtidas nesta pesquisa têm a contribuição significativa do conhecimento desse guia principal, tanto no que se refere ao número de plantas medicinais citadas, como nos diferentes tipos de técnicas de manejo tradicional, de beneficiamento e de comercialização, assim como no que se refere a aspectos políticos, como percepções e opiniões sobre os diferentes atores sociais envolvidos com a extração e comercialização de plantas medicinais da Mata Atlântica. Por sua atuação política, seu conhecimento tradicional e sua preocupação com a conservação das plantas medicinais, esse guia principal tem importante papel na busca da sustentabilidade do desenvolvimento da região do Vale do Ribeira, Estado de São Paulo.

Ele nasceu no Estado de São Paulo e vive no Vale do Ribeira há 13 anos. Antes de viver no Vale, trabalhou com jardinagem na cidade de São Paulo. Quando chegou ao Vale com seu pai para plantar abacaxi e vender doces dessa planta, começou observar as plantas medicinais e a ler sobre o assunto. Assim, com as leituras, as observações e o acompanhamento da reação das plantas medicinais em seus experimentos de extração, ele adquiriu seu conhecimento, e posteriormente aprimorou-o com informações obtidas por meio de conversas com pessoas mais velhas, ou seja, pessoas que apresentavam mais experiência em identificar, diferenciar e saber o uso popular de plantas medicinais da Mata Atlântica. Um desses senhores mais velhos trabalhava com ele.

Não obstante, ele estuda plantas medicinais há 13 anos, segundo suas informações, trabalha com a extração, o cultivo e o beneficiamento de plantas medicinais há cerca de 9 anos. Dentro das possibilidades, procura aperfeiçoar-se cada vez mais nessa prática.

De acordo com suas informações, ele ensina, acompanha e fiscaliza os métodos de extração utilizados por pessoas que ele contrata para extrair plantas medicinais. Afirmou que visita as áreas de extração periodicamente, acompanhado ou não por seus 
extratores, para verificar se eles estão extraindo o material vegetal da maneira adequada e sem depredar o meio ambiente.

Desde os primeiros momentos de nosso convivio, ele se mostrou muito preocupado com a possibilidade de não mais encontrar disponíveis alguns recursos vegetais. Prevê um aumento contínuo das extrações, não só por extratores e produtores que já atuam no Vale, mas principalmente por pessoas que para lá continuam a migrar.

"É só sair uma noticia que o pessoal já vêm e vai tirando (referia-se à extração de plantas medicinais). Alguns estão tirando com cuidado outros não. Esses podem prejudicar toda a classe (referia-se aos extratores, produtores e comerciantes de plantas medicinais). $O$ pessoal está tirando com medo, então tira rápido e isso é muito perigoso. Se houvesse uma liberação eles não iam precisar ter esse medo, então ia preservar mais ainda". (Sr. B)

Sua preocupação relativa à conservação das plantas medicinais, e a conseqüente manutenção de suas atividades comerciais, levaram esse produtor/extrator a se articular com outros produtores e a procurar instituições governamentais e não-governamentais, o que finalmente levou à formação da Aepam. Dessa forma, ele assumiu uma liderança política, mercadológica e de conhecimento sobre a extração e a comercialização de plantas medicinais sobre o grupo de extratores e produtores. Conseqüentemente, ele é um especialista muito procurado por agricultores, por outros produtores e por extratores que desejam aprender como beneficiar com qualidade, como extrair as plantas medicinais, com menos impacto ecológico, como cultivar e principalmente como e para quem vender.

\subsubsection{Percepções dos extratores e produtores sobre as relações entre os atores envolvidos e a conservação das plantas medicinais}

Serão relatadas percepções e opiniões de extratores e produtores de plantas 
medicinais sobre sua relação com o Ibama, o DEPRN, a Polícia Florestal, a Aepam, a conservação das plantas medicinais, assim como sobre sua relação com os outros extratores e produtores. Essas informações foram obtidas em entrevistas informais, semi-estruturadas e abertas, e por meio do emprego da técnica de observação direta participativa. A seguir serão apresentadas tais percepções e opiniões e, quando possível, serão apresentados também contextos políticos, ecológicos, sociais e econômicos inseridos na relação do grupo de estudo com os agentes mencionados. Essas relações serão divididas em:

a. Relações entre os extratores e produtores;

b. Relações entre os extratores/produtores e a Aepam;

c. Relações entre os extratores/produtores e os órgãos governamentais (Ibama, DEPRN e Polícia Florestal);

d. Relações entre os extratores/produtores e os recursos naturais (especialmente plantas medicinais).

\section{a) Relações entre os extratores e produtores}

Os produtores e alguns extratores/produtores geralmente contam com sítios com área de mata, meios de produção, conhecimento sobre as atividades e principalmente sobre o mercado (para quem vender). Os sítios podem ser posses ou propriedades, mas o que mais prevalece é a posse. Os meios de produção englobam a estação de beneficiamento, a embalagem, a armazenagem e o transporte. A estação de beneficiamento possui forno para secagem do material vegetal, estruturas para a triagem, a trituração, a embalagem e o armazenamento do material vegetal.

A relação ocorre principalmente pela defesa de objetivos comuns, mas, em alguns momentos, pode haver competição pelo mercado de plantas medicinais. Em alguns casos, encontram-se também nessa relação objetivos e atitudes diferentes, que causam choques, como pode ser verificado no depoimento abaixo.

"O meu sistema é totalmente diferente. Eu vendo pouco e caro e eles vendem muito e barato. Enquanto eu vendo $1 \mathrm{~kg}$ de material por 
$R \$ 20,00$, eles vendem $1 \mathrm{~kg}$ de material por um valor entre $R \$ 0,40$ e $R S$ 0,50. $O$ intermediário é quem mais ganha na quantidade com baixa qualidade." (Sr. B).

Os principais interesses dos produtores e extratores/produtores para seu fortalecimento, ou seja, sua união e sua proteção, são o acesso ao mercado receptor de plantas medicinais, o conhecimento de técnicas adequadas de extração, cultivo, beneficiamento, armazenagem, transporte e comercialização de plantas medicinais, bem como a possibilidade de legalização das atividade de exploração e comercialização de plantas medicinais na região do Vale do Ribeira.

"Nós estamos querendo sair desse comércio aqui e mandar qualidade para o exterior. Em um primeiro passo, nós estamos tentando o Japão. Se tiver espaço no americano (referia-se aos Estados Unidos da América), nós queremos. " (Sr. B).

Quanto ao conhecimento de manipulação adequada das plantas medicinais, observou-se que há entre produtores e produtores/extratores, de maneira geral, conhecimento mútuo sobre o que cada um está fazendo, inclusive sobre problemas enfrentados.

"Eu tenho um colega ai que quebrou a cara. Ele começou a tirar à vontade (referia-se à extração de plantas medicinais realizada pelo colega). Hoje ele chegou e disse: 'Cara, você tinha razão. Agora estou sem planta... Eu acho que vou começar a trabalhar só com ... (o entrevistado mencionou o nome de uma das plantas medicinais cultivadas)'. Tudo bem, estou há 8 anos aqui e continuo vivendo... (referia-se às atividades de extração, cultivo e comercialização de plantas medicinais). Eu não posso chegar para ele e falar que está errado. A primeira vez a gente fala: não mexa que é perigoso. Mas, se a pessoa mexe, o problema é dela. Eu avisei". (Sr. B) 
Os extratores são aqueles que efetivamente extraem as plantas da natureza, também chamados mateiros. Eles geralmente não possuem terra própria, dependem, portanto, das áreas de mata de produtores ou de outros. Eles não possuem também estação de beneficiamento. Geralmente, extraem e vendem o material fresco (verde). Quando o vendem seco, o processo de secagem é feito à sombra, ao sol ou, ainda, em um forno cedido por um produtor. A relação entre os extratores e os produtores é mediada principalmente pela troca de bens e de serviços. Assim, os extratores recebem pelo seu serviço ou pela mercadoria (material vegetal) vendida. Essa relação pode ser classificada, em geral, como descrita a seguir, de acordo com informações obtidas em entrevistas e observações:

- Extrator como empregado permanente: o extrator extrai o material vegetal, realiza as atividades de cultivo, beneficiamento, transporte, armazenagem, entre outros, e recebe um salário do produtor ou do produtor/extrator, do proprietário das terras. $\mathrm{O}$ extrator pode ser empregado com registro ou não. Outro aspecto importante é que a familia do extrator geralmente trabalha com ele.

- Extrator como empregado temporário: o extrator trabalha para o produtor durante o periodo de safra, extraindo as plantas e participando das outras atividades; na entresafra, eles permanecem desempregados e retornam ao trabalho na safra seguinte.

"O meu pessoal já sabe que nesta época do ano está todo mundo na rua e no começo de março tá todo mundo empregado de novo." (Sr.B)

- Extrator como autônomo: o extrator extrai por conta própria, atendendo a pedidos, e geralmente vende para produtores; pode extrair e vender sempre para determinado produtor ou pode extrair e vender sua mercadoria para aquele que a solicitou. No primeiro caso, o extrator tem um tipo de contrato, geralmente verbal, com um produtor e, no segundo, o extrator atende aos pedidos feitos.

- Extrator como sócio: parece que este é um caso incomum na região do Vale do 
Ribeira, mas pode ocorrer, segundo informações obtidas de extratores, que trabalham nestas condições. Nesse caso, o extrator trabalha para um único produtor e tem participação nos lucros provenientes das vendas realizadas. $O$ extrator realiza quase todas as atividades envolvidas, como extração, cultivo, beneficiamento, transporte, armazenamento, ajuda na comercialização e participa na administração dos negócios.

\section{b) Relações entre os extratores/produtores e a Aepam}

Antes de apresentar percepções e opiniões dos entrevistados sobre os trabalhos da Aepam, serão discutidos os contextos do comércio de plantas medicinais encontrados em 1995 e em 1997.

O contexto do comércio de plantas medicinais na região do Vale do Ribeira segundo foi observado e/ou informado pelos entrevistados, em 1997, mostrou-se bem diferente do apresentado em 1995. Em 1997, muitos dos produtores não tinham para quem vender a produção, que estava sendo estocada em condições inadequadas. Os fornos, bem como toda a estrutura de beneficiamento, estava abandonados e inativados.

Em conseqüência disso, reinava entre alguns extratores e produtores um clima de desânimo, que, entretanto, tentavam superar com criatividade, voltando-se para outras atividades econômicas, como cultivo de banana e chá, exploração de pedreiras e de fontes de água mineral. Outros extratores e produtores se mudaram para outras regiões do Estado em busca de novas formas de obtenção de renda.

Além da dificuldade em vender a mercadoria, era difícil também receber o pagamento dos pedidos já atendidos. Segundo os entrevistados, os pagamentos geralmente eram feitos pelos intermediários, porém, muitas vezes, não em moeda, mas sim em aparelhos, como, por exemplo, eletrodomésticos usados.

Diante do panorama encontrado em 1997, a regulamentação das atividades de exploração e comercialização de plantas medicinais não constituia a principal luta da maioria dos extratores e produtores, e sim a obtenção de meios de acessar mercados que possibilitassem a continuidade dessas atividades com plantas medicinais. Caso contrário, de nada adiantaria a legalização das atividades de exploração e comercialização. 
Provavelmente, como conseqüência da mudança do panorama do mercado de plantas medicinais, entre 1995 e 1997, a legitimidade da Aepam como órgão de representação estava com a credibilidade abalada. Alguns entrevistados justificavam essa perda de credibilidade pela mudança do panorama do mercado e, acrescentavam a isso o monopólio de informações por determinados membros da Aepam.

Alguns depoimentos realizados estão apresentados a seguir:

"Praticamente não existe a Aepam!" (Sr D)

“Hoje, não participo mais das reuniões! Nunca dá em nada. Não vale a pena nem sair daqui para isso." (Sr. F)

"Tenho participado em consideração a (referia-se a um sócio da Aepam), senão não ia mais." (Sr. D)

\section{c) Relacões entre os extratores/produtores e os órgãos governamentais}

A partir do levantamento da percepção e das opiniões dos produtores e extratores em relação aos órgãos governamentais (Ibama, DEPRN e Polícia Florestal), verifica-se uma relação conflituosa entre esses atores sociais. Porém, mesmo em 1997, havia um panorama mais ou menos favorável de tentativa de acordo entre as partes (ver 2.2 - A gênese da Aepam). Mas alguns produtores e principalmente extratores acreditavam que todos esses órgãos governamentais estavam ali para fiscalizar, multar, repreender.

A clandestinidade das atividades de exploração e comercialização de plantas medicinais da Mata Atlântica é responsável também por esse conflito. Outro motivo, provavelmente o principal, é a questão fundiária da região do Vale do Ribeira que é extremamente complexa em conseqüência da falta de títulos de propriedade da terra. Além disso, a alta porcentagem de áreas desse Vale, principalmente as que contém áreas de floresta, onde se encontram as plantas medicinais, e que se localizam dentro de unidades de conservação, que legalmente não podem ser usadas na exploração de recursos naturais, inclusive no de plantas medicinais (ver 4.2 - A região do Vale do Ribeira) acaba também sendo motivo de conflitos.

Quando os entrevistados eram interrogados sobre a propriedade da área de 
extração das plantas medicinais ou sobre a identificação das áreas usadas para sua extração, a preocupação e o desconforto predominavam em suas reações.

Graças às irregularidades presentes nas atividades de exploração e comercialização de plantas medicinais, segundo os entrevistados, as informações fornecidas aos órgãos governamentais mencionados acima não são completas, ou seja, vários dados são omitidos.

"Isto (referia-se a determinada planta medicinal) eu não coloquei na lista do Ibama". (Sr. F)

“(...) (referia-se a um produtor/extrator) está tirando (referia-se à extração de plantas medicinais) de dentro da Reserva Florestal $e$ mandando para São Paulo! (...) estão dentro da reserva porque fora da reserva o governo não deixa tirar, o próprio governo atrapalha." (Sr. F)

Um outro fator levantado, bastante preocupante, foram as queixas de corrupção e extorsão, principalmente relacionadas à Polícia Florestal; esse fator agrava em muito os conflitos com os órgãos do governo.

"Eu tenho como provar que o guarda pegou dinheiro duas vezes e depois multou."

"Os guardas levam dinheiro e deixam os grandes desmatar."

"Por que esse pessoal faz essas coisa? Eles (os extratores) não vão mais acreditar ...".

\section{d) Relações entre os extratores/produtores e os recursos naturais}

A relação entre os extratores, produtores e as plantas medicinais, assim como, outros recursos naturais, é caracterizada pela dependência econômica deles para com esses recursos. Assim, a preocupação que existe com a conservação das plantas medicinais fica por conta do receio de não mais as ter no futuro para suprir as necessidades comerciais. Porém, essa preocupação acaba se ocorrer uma boa oferta, um 
pedido "muito bom", do ponto de vista financeiro.

Durante as entrevistas, foi possivel obter-se três percepções e opiniões diferentes quanto à conservação das plantas medicinais:

a. Alguns acreditam que as plantas medicinais vão acabar e não há nada que os atores sociais envolvidos possam fazer para mudar esse panorama;

b. Outros acham que se a Mata Atlântica continuar a ser usada de forma "desregrada", ou seja, a sofrer tal desmatamento, as plantas medicinais podem acabar. Por outro lado, acreditam que as pesquisas em potencial sobre o manejo sustentável, assim como o cultivo, podem levar a soluções e à elaboração dos critérios necessários para regulamentar o uso, conduzindo à conservação dessas plantas. Esses entrevistados acham que esses estudos devem ser realizados e repassados para a população para que o comércio de plantas medicinais venha a constituir uma alternativa verdadeira para a melhoria das condições de vida das comunidades que vivem na área rural. Os entrevistados citaram o projeto Da mata à casa (ver 2.3 - O projeto Da mata à casa), sugerindo que ele deveria ser seguido como exemplo.

c. Outros ainda não apresentam a menor preocupação com a conservação de plantas medicinais, conforme apresentado no depoimento abaixo.

"Meu avô trabalhava com isto; meu pai trabalhou a vida toda! $E$ as plantas continuam todas ai!" (Sr. A).

\subsection{O saber etnobotânico da amostra de extratores e produtores de plantas medicinais}

Os dados obtidos e analisados sobre o conhecimento tradicional da amostra de extratores e produtores de plantas medicinais acerca da extração, do beneficiamento e da comercialização dessas plantas, assim como os dados levantados nas bibliografias consultadas sobre origem, ação farmacológica, fitoquímica e mercado das espécies 
medicinais levantadas com a amostra encontram-se nos quatro itens a seguir: 5.3.1 - As plantas manejadas; 5.3.2 - As áreas do manejo tradicional; 5.3.3 - O manejo tradicional, 5.3.4 - O beneficiamento e a comercialização e 5.3.5 - Correlações entre dados.

\subsubsection{As plantas manejadas}

A amostra de extratores e produtores de plantas medicinais da região do Vale do Ribeira fez menção a 148 plantas. Desse total de plantas citadas, 129 plantas foram identificadas pelos entrevistados e delas foram coletadas amostras para proceder à identificação botânica. O principal motivo que impediu a coleta de material das 19 plantas não coletadas, ou seja $12,8 \%$ do total, foi o fato de os entrevistados não as terem localizado por serem raras ou então pela dificuldade de acesso aos possíveis locais onde se encontrariam.

Das plantas coletadas, 173 foram identificadas botanicamente, sendo 120 até o nível de espécie (69\% do total, inclusive as à confirmar), 34 até o nível de gênero (20\%) e 19 até o nível de família (11\%), conforme mostra o gráfico 2 .

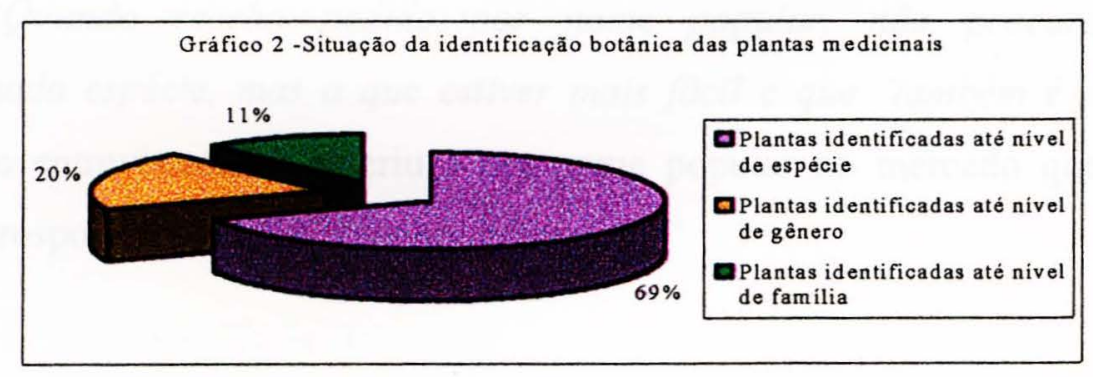


O número grande de plantas identificadas botanicamente (173 plantas) comparado com o número de plantas coletadas (129 plantas) é justificado por mais de uma espécie ser conhecida pelo mesmo nome popular. Um único entrevistado pode identificar plantas diferentes com o mesmo nome popular, ou ainda, o mais comum, entrevistados diferentes podem identificar plantas diferentes com o mesmo nome popular. Ocorre também o contrário, dois ou mais nomes populares diferentes corresponderem a uma mesma espécie. No caso dos extratores e produtores, ocorreu mais de um nome popular para diferentes espécies. Por isso, o número de espécies medicinais manejadas tradicionalmente poderá aumentar, quando as plantas não-identificadas e não-coletadas forem identificadas, até o nível de espécie. Isso é justificado pelas semelhanças morfológicas de plantas muito próximas, o que dificulta sua diferenciação por quem as manipula, e pela sinonimia popular (ou seja, espécies diferentes com o mesmo nome popular). Segundo a amostra dos extratores e produtores, há cerca de 60 espécies diferentes que têm o nome popular de salsaparrilha. Esse grande número de espécies com o único nome popular ocorre principalmente pelo motivo de existirem várias espécies no mercado com o mesmo nome popular, já que, sendo assim, o extrator ou produtor pode coletar e vender plantas diferentes daquela que está sendo solicitada, o que pode ser observado no seguinte depoimento:

"Quando recebo pedido por nome popular, não procuro determinada espécie, mas a que estiver mais fácil e que também é a fulana (o entrevistado se referiu a um nome popular no mercado que pode corresponder a várias espécies diferentes). "

O motivo responsável pela identificação botânica não chegar, em muitos casos, até o nível de espécie foi que nem todas as plantas puderam ser coletadas com flores ou frutos. As dificuldades em se encontrar material fértil das plantas citadas pelos entrevistados são características nos levantamentos etnobotânicos, pois as amostras de tais plantas devem ser coletadas quando o entrevistado fizer sua identificação. $O$ entrevistado cita, quase sempre, todas as plantas de seu conhecimento, mesmo aquelas dificeis de serem encontradas. No momento em que o entrevistado identifica a planta, 
ela pode estar em seu estado fértil ou não. Para tentar resolver esse problema, esta pesquisa durou mais de 13 meses, período geralmente recomendado para haver maior possibilidade de coletar material fértil das referidas plantas identificadas. Para isso, foram revisitados os locais onde se encontravam as plantas coletadas desprovidas de material fértil. Quando possível, esse retorno foi em companhia do entrevistado.

A existência de um grande número de espécies em relação ao número das plantas coletadas pode ser verificada também nas tabelas 1, 2 e 3, no anexo 4. Esses anexos apresentam a lista de todas as plantas citadas e identificadas pelos entrevistados, bem como sua identificação botânica, realizada à luz da ciência ocidental. As tabelas 1 , 2 e 3 ordenam a lista dessas plantas pelos nomes populares, nomes científicos e pelas famílias botânicas, respectivamente.

Foram verificados também os gradientes de ocorrência das famílias que podem ser vistos no gráfico 3. Entre as famílias mais encontradas, destacaram-se Asteraceae, Myrtaceae e Euphorbiaceae. As famílias menos citadas formaram dois grupos, conforme apresentados a seguir:

1. grupo com 12 famílias relacionadas a seguir, que tiveram duas citações cada: Chenopodiaceae, Commelinaceae, Dilleniaceae, Flacourtiaceae, Gramineae, Malvaceae, Melastomataceae, Passifloraceae, Polygonaceae, Sapindaceae, Scrophulariaceae, Urticaceae;

2. grupo com 20 famílias, também relacionadas a seguir, que tiveram uma citação cada: Alismataceae, Amaranthaceae, Anacardiaceae, Annonaceae, Araceae, Arecaceae, Aristolochiaceae, Cactaceae, Costaceae, Cyperaceae, Guttiferae, Iridaceae, Loranthaceae, Lythraceae, Malpighiaceae, Moraceae, Quinaceae, Ranunculaceae, Theaceae, Umbelliferae.

No gráfico3, mencionado acima, serão apresentados os totais de cada grupo. 
Gráfico 3 - Frequência de ocorrência das fam ilias das plantas citadas

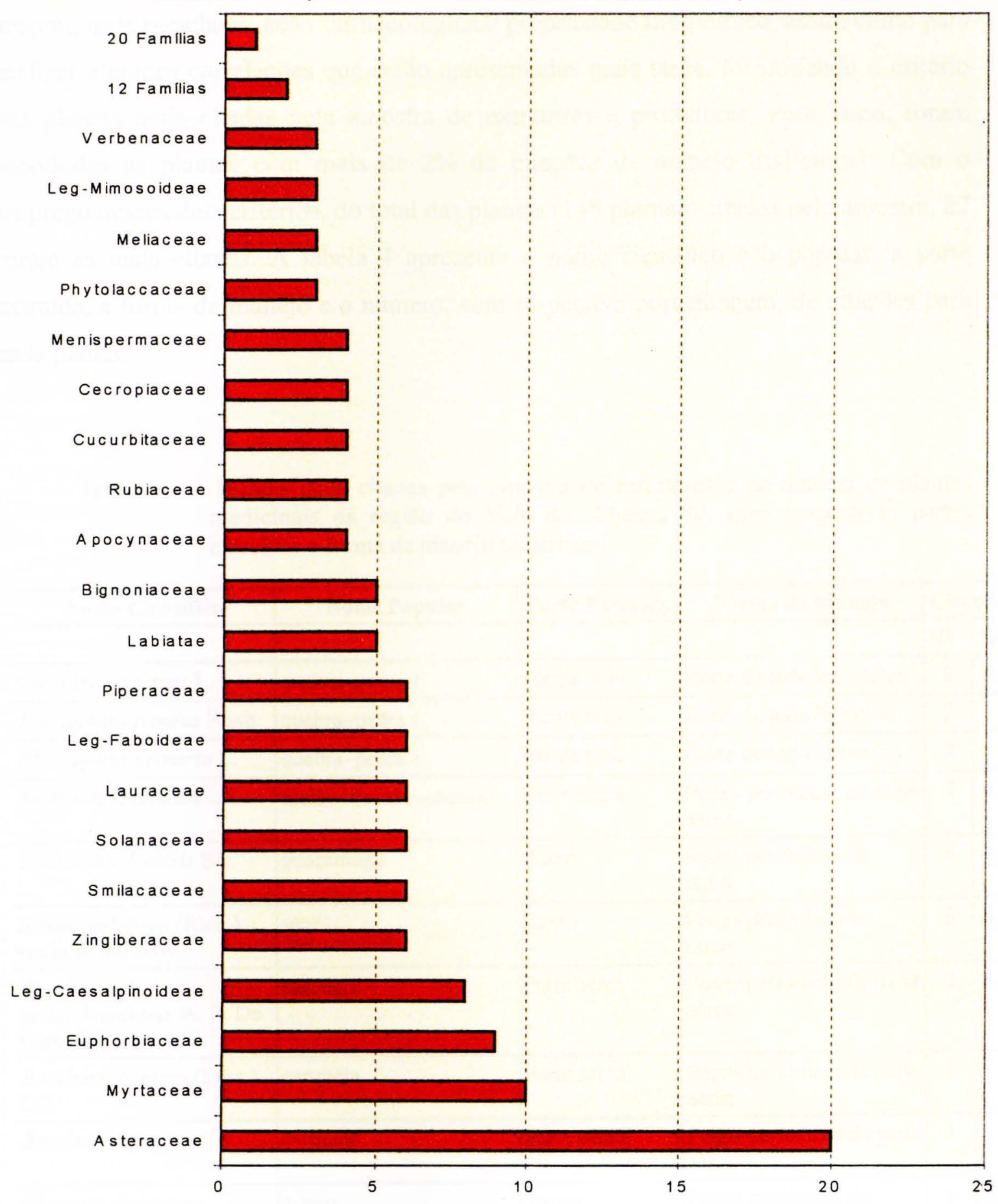


Para apresentar os resultados dos levantamentos bibliográficos realizados sobre origem, usos populares, ação farmacológica e propriedade fitoquímica, assim como para realizar algumas correlações que serão apresentadas mais tarde, foi utilizado o critério das plantas mais citadas pela amostra de extratores e produtores. Para tanto, foram escolhidas as plantas com mais de $2 \%$ de citações de manejo tradicional. Com o emprego desses dois critérios, do total das plantas (148 plantas) citadas pela amostra, 27 foram as mais citadas. A tabela 4 apresenta o nome científico e o popular, a parte extraída, a forma de manejo e o número, com respectiva porcentagem, de citações para cada planta.

Tabela 4 - Plantas mais citadas pela amostra de extratores e produtores de plantas medicinais da região do Vale do Ribeira, SP, com respectivas partes extraídas e forma de manejo tradicional

\begin{tabular}{|c|c|c|c|c|c|}
\hline \multirow[t]{2}{*}{ Nome Científico } & \multirow[t]{2}{*}{ Nome Popular } & \multirow[t]{2}{*}{ Parte Extraida } & \multirow[t]{2}{*}{ Forma de Manejo } & \multicolumn{2}{|c|}{ Citaçōes } \\
\hline & & & & $\mathbf{N}^{\mathbf{2}}$ & $\%$ \\
\hline Phyllanthus niruri L. & quebra-pedra 1 & Planta toda & Corte de todo indivíduo & 3 & 4,7 \\
\hline Phyllanthus tenelus Roxb. & quebra-pedra 1 & Planta toda & Corte de todo individuo & 2 & \\
\hline Phyllanthus urinaria L. & quebra-pedra 1 & Planta toda & Corte de todo indivíduo & 2 & \\
\hline Momordica charantia L. & melão-de-são-caetano & Parte aérea & $\begin{array}{l}\text { Podas periódicas da parte } \\
\text { aérea }\end{array}$ & 7 & 4,7 \\
\hline Casearia sylvestris Sw. & guaçatonga & Ramo & $\begin{array}{l}\text { Podas periódicas do } \\
\text { ramo }\end{array}$ & 6 & 4,1 \\
\hline $\begin{array}{l}\text { Senna multijuga (Rich.) } \\
\text { Irwin \& Barneby }\end{array}$ & sene & Ramo & $\begin{array}{l}\text { Podas periódicas do } \\
\text { ramo }\end{array}$ & 6 & 4,1 \\
\hline $\begin{array}{l}\text { Baccharis cf } \\
\text { gaudichaudiana A. P. De } \\
\text { Candolle }\end{array}$ & carqueja & Parte aérea & $\begin{array}{l}\text { Podas periódicas da parte } \\
\text { aérea }\end{array}$ & 3 & 3,4 \\
\hline $\begin{array}{l}\text { Baccharis trimera (Less.) } \\
\text { DC. }\end{array}$ & carqueja & Parte aérea & $\begin{array}{l}\text { Podas periódicas da parte } \\
\text { aérea }\end{array}$ & 1 & \\
\hline Baccharis sp. & carqueja & Parte aérea & $\begin{array}{l}\text { Podas periódicas da parte } \\
\text { aérea }\end{array}$ & 1 & \\
\hline $\begin{array}{l}\text { Clematis dioica var. } \\
\text { brasiliana (D.C.) Elchler }\end{array}$ & guaco & Ramo & $\begin{array}{l}\text { Podas periódicas do } \\
\text { ramo }\end{array}$ & 5 & 3,4 \\
\hline Polygonum cf. pontudo & erva-de-bicho & Planta toda & Corte de todo indivíduo & 2 & 3,4 \\
\hline Polygonum cf. pontudo & erva-de-bicho & Parte aérea & $\begin{array}{l}\text { Podas periódicas da parte } \\
\text { aérea }\end{array}$ & 1 & \\
\hline $\begin{array}{l}\text { Polygonum } \\
\text { hydropiperoides Michx. }\end{array}$ & erva-de-bicho & Planta toda & Corte de todo individuo & 2 & \\
\hline & & & & & \\
\hline
\end{tabular}




\begin{tabular}{|c|c|c|c|c|c|}
\hline Nome Científico & Nome Popular & Parte Extraída & Forma de Manejo & \multicolumn{2}{|c|}{ Citações } \\
\hline $\begin{array}{l}\text { Costus spiralis (Jacq.) } \\
\text { Roscoe }\end{array}$ & cana-do-brejo & Parte aérea & $\begin{array}{l}\text { Podas periódicas da parte } \\
\text { aérea }\end{array}$ & 4 & 2,7 \\
\hline $\begin{array}{l}\text { Cuphea cartaginensis } \\
\text { (Jacq.) Macbr. }\end{array}$ & erva-de-sete-sangrias & Planta toda & Corte de todo individuo & 4 & 2,7 \\
\hline Bauhinia sp. & pata-de-vaca & Ramo & $\begin{array}{l}\text { Podas periódicas do } \\
\text { ramo }\end{array}$ & 4 & 2,7 \\
\hline $\begin{array}{l}\text { Mikania cf. hirsutissima } \\
\text { D.C. }\end{array}$ & cipó-cabeludo & Ramo & $\begin{array}{l}\text { Podas periódicas do } \\
\text { ramo }\end{array}$ & 3 & 2,7 \\
\hline $\begin{array}{l}\text { Mikania cf. hirsutissima } \\
\text { D.C. }\end{array}$ & cipó-cabeludo & cipó & $\begin{array}{l}\text { Podas periódicas da parte } \\
\text { aérea }\end{array}$ & 1 & \\
\hline $\begin{array}{l}\text { Hymenaea courbaril L. } \\
\text { var. - altissima (Ducke) } \\
\text { Lee \& Lang. }\end{array}$ & jatobá & Casca do caule & $\begin{array}{l}\text { Descasca } 50 \% \text { da planta } \\
\text { unilateralmente }\end{array}$ & 2 & 2,7 \\
\hline $\begin{array}{l}\text { Hymenaea courbaril L. } \\
\text { var. - altissima (Ducke) } \\
\text { Lee \& Lang. }\end{array}$ & jatobá & Semente & Recolhimento do chão & 1 & \\
\hline $\begin{array}{l}\text { Hymenaea courbaril L. } \\
\text { var. - altissima (Ducke) } \\
\text { Lee \& Lang. }\end{array}$ & jatobá & Resina & sangrias & 1 & \\
\hline $\begin{array}{l}\text { Schinus terebinthifolius } \\
\text { Raddi. }\end{array}$ & arrueira & Casca do caule & $\begin{array}{l}\text { Descasca } 50 \% \text { da planta } \\
\text { unilateralmente }\end{array}$ & 1 & 2,7 \\
\hline $\begin{array}{l}\text { Schinus terebinthifolius } \\
\text { Raddi. }\end{array}$ & arrueira & Fruto & $\begin{array}{l}\text { Podas periódicas do } \\
\text { ramo }\end{array}$ & 1 & \\
\hline $\begin{array}{l}\text { Schinus terebinthifolius } \\
\text { Raddi.. }\end{array}$ & arrueira & Ramo & $\begin{array}{l}\text { Podas periódicas do } \\
\text { ramo }\end{array}$ & 1 & \\
\hline $\begin{array}{l}\text { Schinus terebinthifolius } \\
\text { Raddi. }\end{array}$ & arrueira & Resina & sangrias & 1 & \\
\hline $\begin{array}{l}\text { Jacaranda puberula } \\
\text { Cham. }\end{array}$ & carobinha 1 & Ramo & $\begin{array}{l}\text { Podas periódicas do } \\
\text { ramo }\end{array}$ & 2 & 2,0 \\
\hline \multirow[t]{3}{*}{ Jacaranda sp } & carobinha 1 & Ramo & $\begin{array}{l}\text { Podas periódicas do } \\
\text { ramo }\end{array}$ & 1 & \\
\hline & picão-preto & Planta toda & Corte de todo individuo & 1 & 2,0 \\
\hline & picão-preto & Planta toda & Corte de todo indivíduo & 1 & \\
\hline Bidens pilosa $\mathrm{L}$. & picão & Parte aérea & $\begin{array}{l}\text { Podas periódicas da parte } \\
\text { aérea }\end{array}$ & 1 & \\
\hline $\begin{array}{l}\text { Sorocea bonplandii } \\
\text { (Baill.) W. C. Burguer }\end{array}$ & espinheira-santa 1 & Ramo & $\begin{array}{l}\text { Podas periódicas do } \\
\text { ramo }\end{array}$ & 2 & 2,0 \\
\hline $\begin{array}{l}\text { Zollernia ilicifolia } \\
\text { (Brongn.) Vog. }\end{array}$ & espinheira-santa 1 & Ramo & $\begin{array}{l}\text { Podas periódicas do } \\
\text { ramo }\end{array}$ & 1 & \\
\hline $\begin{array}{l}\text { Baccharis cassinefolia } \\
\text { DC. }\end{array}$ & jaborandi 1 & Ramo & $\begin{array}{l}\text { Podas periódicas do } \\
\text { ramo }\end{array}$ & 3 & 2,0 \\
\hline Cecropia glaziovi Snethl. & embaúba & Folha & Corte de todo indivíduo & 1 & 2,0 \\
\hline Cecropia sp & embaúba & Folha & Corte de todo indivíduo & 1 & \\
\hline $\begin{array}{l}\text { Cecropia pachystachya } \\
\text { Trèc. }\end{array}$ & embaúba & Folha & Corte de todo indivíduo & 1 & \\
\hline Ageratum conyzoides $\mathrm{L}$. & erva-de-são-joão & Planta toda & Corte de todo indivíduo & 2 & 2,0 \\
\hline
\end{tabular}




\begin{tabular}{|c|c|c|c|c|c|}
\hline \multirow{2}{*}{$\frac{\text { Nome Cientifico }}{\text { Ageratum conyzoides } \mathrm{L} .}$} & \multirow{2}{*}{\begin{tabular}{|l|} 
Nome Popular \\
erva-de-são-joão
\end{tabular}} & \multirow{2}{*}{\begin{tabular}{|l|} 
Parte Extraída \\
Parte aérea
\end{tabular}} & \multirow{2}{*}{\begin{tabular}{|l|}
\multicolumn{1}{|c|}{ Forma de Manejo } \\
$\begin{array}{l}\text { Podas periódicas da parte } \\
\text { aérea }\end{array}$ \\
\end{tabular}} & \multicolumn{2}{|c|}{ Citações } \\
\hline & & & & 1 & \\
\hline $\begin{array}{l}\text { Chenopodium } \\
\text { ambrosioides } \mathrm{L} \text {. }\end{array}$ & erva-de-santa-maria & Planta toda & Corte de todo indivíduo & 2 & 2,0 \\
\hline \multirow[t]{3}{*}{$\begin{array}{l}\text { Chenopodium } \\
\text { ambrosioides } \mathrm{L} .\end{array}$} & erva-de-santa-maria & Parte aérea & $\begin{array}{l}\text { Podas periódicas da parte } \\
\text { aérea }\end{array}$ & 1 & \\
\hline & cipó-cravo & cipó & $\begin{array}{l}\text { Podas periódicas da parte } \\
\text { aérea }\end{array}$ & 2 & 2,0 \\
\hline & cipó-cravo & Parte aérea & $\begin{array}{l}\text { Podas periódicas da parte } \\
\text { aérea }\end{array}$ & 1 & \\
\hline $\begin{array}{l}\text { Echinodorus grandiflorus } \\
\text { (Cham. et Schlecht.) Mich. }\end{array}$ & chapéu-de-couro & Folha & Outros & 2 & 2,0 \\
\hline $\begin{array}{l}\text { Echinodorus grandiflorus } \\
\text { (Cham. e Schlecht.) Mich }\end{array}$ & chapéu-de-couro & Parte aérea & $\begin{array}{l}\text { Podas periódicas da parte } \\
\text { aérea }\end{array}$ & 1 & \\
\hline Vernonia sp. & assa-peixe & Ramo & $\begin{array}{l}\text { Podas periódicas do } \\
\text { ramo }\end{array}$ & 2 & 2,0 \\
\hline Vernonia sp. & assa-peixe & Raiz & Corte de todo indivíduo & 1 & \\
\hline $\begin{array}{l}\text { Senna occidentalis (L.) } \\
\text { Link }\end{array}$ & fedegoso & Planta toda & Corte de todo individuo & 1 & 2,0 \\
\hline $\begin{array}{l}\text { Senna occidentalis (L.) } \\
\text { Link }\end{array}$ & fedegoso & Raiz & Corte de todo indivíduo & 1 & \\
\hline Senna sp & fedegoso & Planta toda & Corte de todo indivíduo & 1 & \\
\hline $\begin{array}{l}\text { Smilax cf subsessiliflora } \\
\text { Duhamel }\end{array}$ & salssaparrilha 1 & Raiz & Corte de todo indivíduo & 1 & 2,0 \\
\hline Smilax elastica Griseb. & salssaparrilha 1 & Planta toda & Corte de todo indivíduo & 1 & \\
\hline Smilax fluminensis Steud. & salssaparrilha 1 & Raiz & Corte de todo individuo & 1 & \\
\hline Coix lacryma Jobi L. & capiá-rosário & Semente & Outros & 1 & 2,0 \\
\hline Coix lacryma Jobi L. & capiá-rosário & Planta toda & Corte de todo individuo & 1 & \\
\hline Coix lacryma Jobi L. & capiá-rosário & Fruto & Recolhimento do chão & 1 & \\
\hline $\begin{array}{l}\text { Ocotea dispersa (Nees.) } \\
\text { Mez. }\end{array}$ & sassafrás 1 & Lenho & Outros & & \\
\hline $\begin{array}{l}\text { Ocotea } \text { cf. odorifera } \\
\text { (Veil.) Rohwer }\end{array}$ & sassafrás 1 & Lenho & Outros & 1 & \\
\hline $\begin{array}{l}\text { Ocotea dispersa (Nees.) } \\
\text { Mez }\end{array}$ & sassafrás 1 & Raiz & Outros & & \\
\hline $\begin{array}{l}\text { Ocotea cf. odorifera } \\
\text { (Vell.) Rohwer }\end{array}$ & sassafrás 1 & Raiz & Outros & 1 & 2,0 \\
\hline $\begin{array}{l}\text { Ocotea dispersa (Nees.) } \\
\text { Mez }\end{array}$ & sassafrás 1 & Casca do caule & $\begin{array}{l}\text { Descasca } 50 \% \text { da planta } \\
\text { unilateralmente }\end{array}$ & & \\
\hline $\begin{array}{l}\text { Ocotea cf. odorifera } \\
\text { (Vell.) Rohwer }\end{array}$ & sassafrás 1 & Casca do caule & $\begin{array}{l}\text { Descasca } 50 \% \text { da planta } \\
\text { unilateralmente }\end{array}$ & 1 & \\
\hline
\end{tabular}

Os entrevistados citaram um total de 244 fichas de manejo tradicional (ver item 
5.3.3 - O manejo tradicional). Das que foram citadas: 107 fichas foram para as plantas mais citadas e 137 fichas para as outras plantas. A média de fichas de manejo tradicional para cada planta dos dois grupos foi a seguinte: 4,0 para cada planta do grupo das mais citadas, e 1,1 para cada planta do grupo das menos citadas. O gráfico 4 mostra que mais da metade da pressão de extração de plantas medicinais na região do Vale do Ribeira (SP) está concentrada em 27 plantas ou 33 espécies, respectivamente, quando se considera o nome popular ou o nome científico das plantas identificadas até o nível de espécie.

Gráfico 4 - Número médio de fichas de manejo tradicional por planta dos dois grupos das mais e menos citadas pela amostra dos extratores e produtores de plantas medicinais da região do Vale do Ribeira, SP.

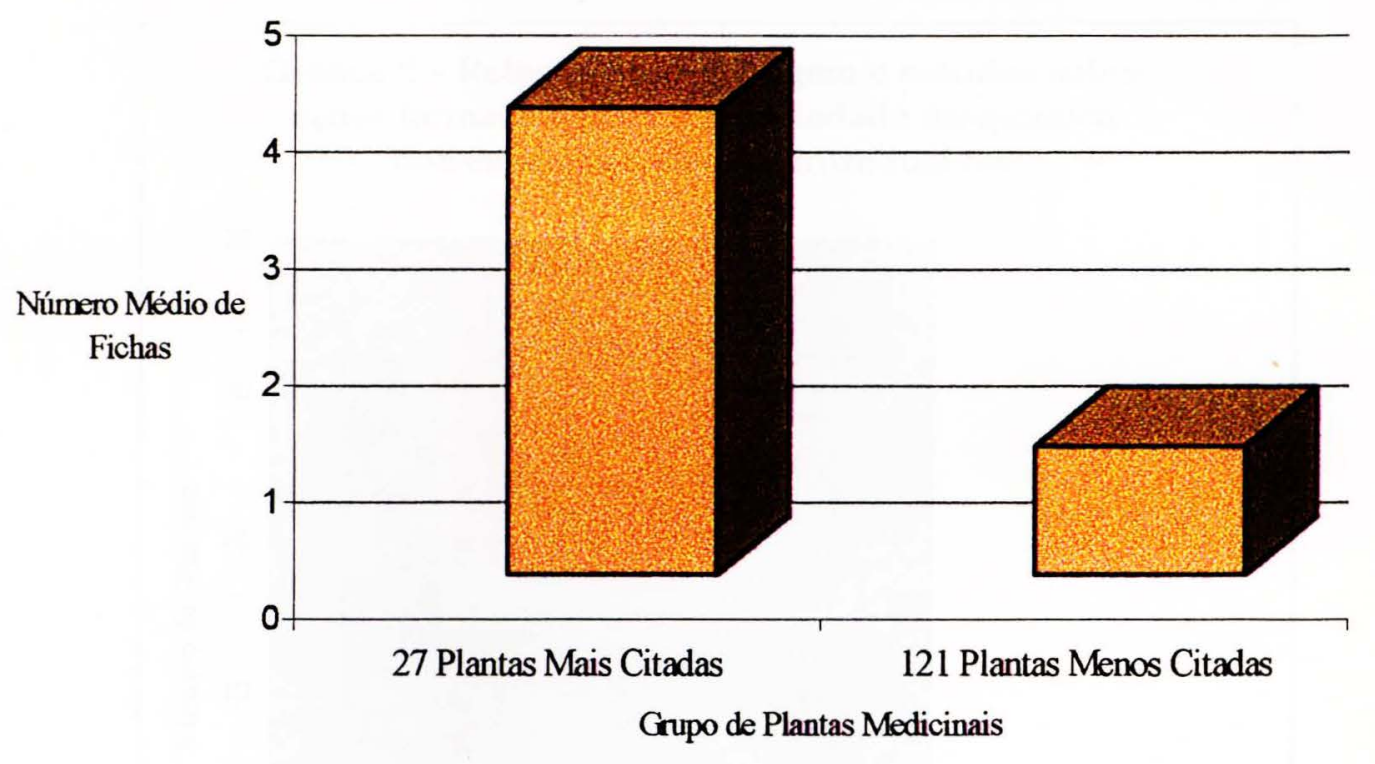

Os dados bibliográficos levantados, em bibliografia especializada, sobre a origem das espécies vegetais, sobre os estudos científicos já realizados relativos à ação farmacológica e à propriedade fitoquímica e sobre o uso popular das espécies identificadas, estão na tabela 5 (ver anexo 4) - apenas para as espécies mais citadas.

O levantamento realizado sobre a origem das 120 espécies mostrou que $64 \%$ 
delas, ou seja, 77 espécies, são nativas da flora brasileira, conforme apresenta o gráfico 5. Cerca de $50 \%$ das espécies nativas (cerca de 39 espécies) já foram estudadas no meio científico sobre ação farmacológica e a propriedade fitoquímica, conforme apresenta o gráfico 6.

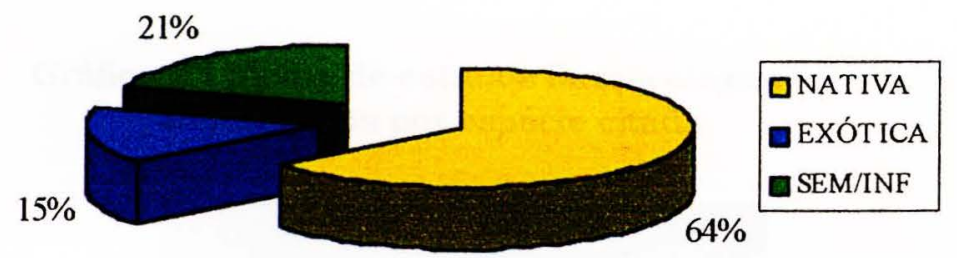

Gráfico 6 - Relação entre a origem e estudos sobre ações farmacológicas e propriedade fitoquímica das espécies nativas e introduzidas

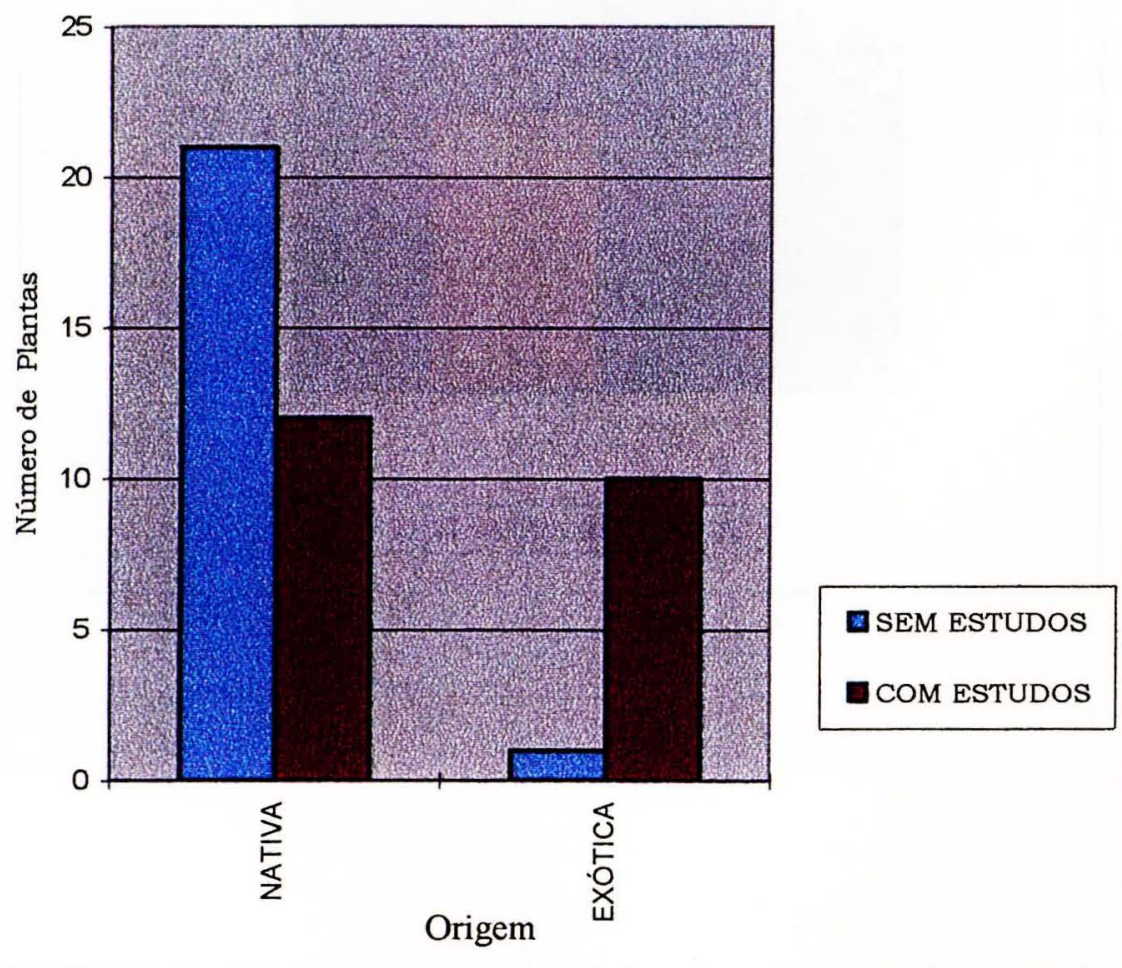


Em relação ao número de trabalhos científicos sobre ação farmacológica e propriedade fitoquímica para cada espécie nativa e introduzida, os dados obtidos mostraram que o número médio de trabalhos para cada espécie exótica (ou seja, introduzida) é maior que o dobro do número de trabalhos para cada espécie nativa, conforme mostra o gráfico 7 .

Gráfico 7 - Média de estudos farmacōlogicos e fitoquímicos por espécie citada

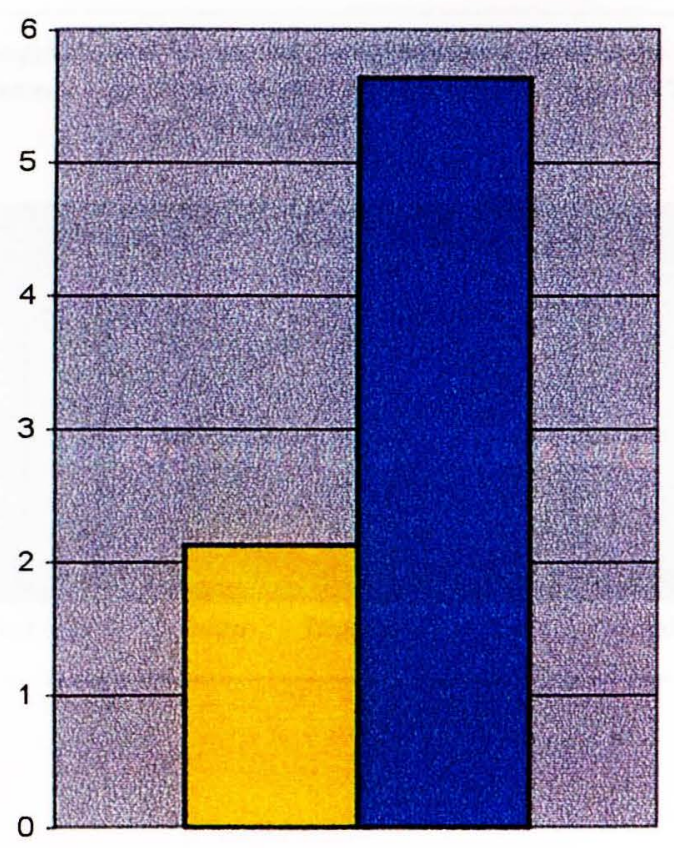

口NATIVA —EXÓTICA 
O hábito, a ocorrência e o hábitat das plantas citadas e identificadas pelos entrevistados foram observados em campo durante a coleta do material vegetal. Das 129 plantas citadas e identificadas pela amostra dos extratores e produtores, 116 ocorrem naturalmente (espontaneamente), 6 são cultivadas e 7 podem ser encontradas cultivadas ou ocorrendo de forma espontânea. Quanto ao hábito dessas plantas, as árvores são mais freqüentes e a seguir, em ordem decrescente, herbáceas, arbustos, trepadeiras, lianas (cipós) e epífitas, conforme mostra o gráfico 8.

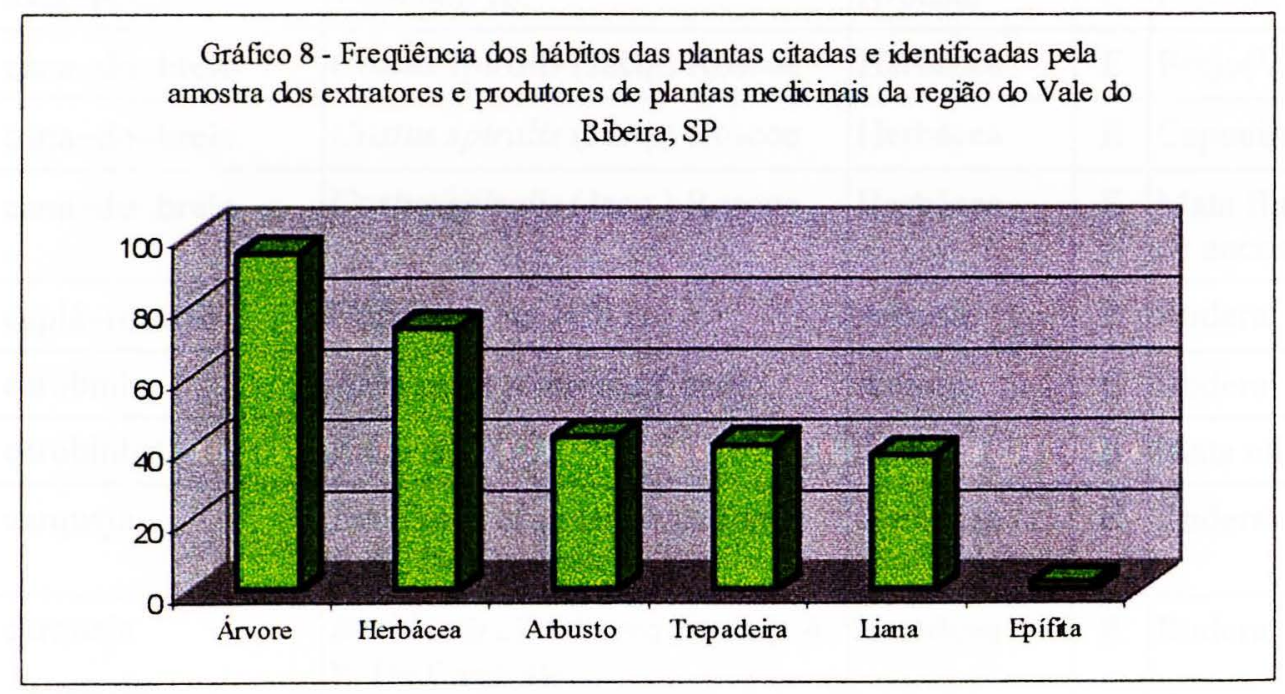

A tabela 6 apresenta o hábito, a ocorrência e o hábitat das plantas mais citadas pelos entrevistados. 
Tabela 6 - Hábito, ocorrência e hábitat das plantas mais citadas pela amostra dos extratores e produtores de plantas medicinais da região do Vale do Ribeira, SP.

\begin{tabular}{|c|c|c|c|c|}
\hline Nome popular & Nome cientifico & Hábito & $\begin{array}{l}\text { Oc } \\
\text { or. }\end{array}$ & Habitat \\
\hline arrueira & Schinus terebinthifolius Raddi. & Árvore & $\mathrm{E}$ & Capoeira \\
\hline arrueira & Schinus terebinthifolius Raddi. & Árvore & $\mathrm{E}$ & $\begin{array}{l}\text { Mata } \\
\text { secundária }\end{array}$ \\
\hline assa-peixe & Vernonia sp. & Arbusto & $\mathrm{E}$ & Ruderal \\
\hline cana-do-brejo & Costus spiralis (Jacq.) Roscoe & Herbácea & $\mathrm{E}$ & Brejo(Várzea) \\
\hline cana-do-brejo & Costus spiralis (Jacq.) Roscoe & Herbácea & $\mathrm{E}$ & Capoeira \\
\hline cana-do-brejo & Costus spiralis (Jacq.) Roscoe & Herbácea & $\mathrm{E}$ & $\begin{array}{l}\text { Mata fluvial } \\
\text { de encosta }\end{array}$ \\
\hline capiá-rosário & Coix lacryma Jobi L. & Arbusto & $\mathrm{E}$ & Ruderal \\
\hline carobinha 1 & Jacaranda puberula Cham. & Árvore & $\mathrm{E}$ & Ruderal \\
\hline carobinha 1 & Jacaranda sp & Árvore & $\mathrm{E}$ & Mata ciliar \\
\hline carqueja & $\begin{array}{l}\text { Baccharis cf gaudichaudiana } \\
\text { A. P. De Candolle }\end{array}$ & Herbácea & $\mathrm{E}$ & Ruderal \\
\hline carqueja & $\begin{array}{l}\text { Baccharis cf. trimera (Less.) A. } \\
\text { P. De Candolle }\end{array}$ & Herbácea & $\mathrm{E}$ & Ruderal \\
\hline carqueja & Baccharis sp. & Herbácea & E & $\begin{array}{l}\text { Mata } \\
\text { inundável }\end{array}$ \\
\hline carqueja & Pterocaulon sp. & Herbácea & $\mathrm{C}$ & \\
\hline chapéu-de-couro & $\begin{array}{l}\text { Echinodorus grandiflorus } \\
\text { (Cham. Et Schlecht.) Mich. }\end{array}$ & Herbácea & $\mathrm{E}$ & Brejo(Várzea) \\
\hline cipó-cabeludo & Mikania cf. hirsutissima D.C. & Liana(Cipó) & $E$ & Capoeira \\
\hline cipó-cabeludo & Mikania cf. hirsutissima D.C. & Liana(Cipó) & $E$ & Brejo(Várzea) \\
\hline cipó-cabeludo & Mikania $\mathrm{cf}$. hirsutissima D.C. & Liana(Cipó) & $\mathrm{E}$ & $\begin{array}{l}\text { Mata fluvial } \\
\text { de encosta }\end{array}$ \\
\hline cipó-cabeludo & Mikania cf. hirsutissima D.C. & Liana(Cipó) & $\mathrm{E}$ & $\begin{array}{l}\text { Mata } \\
\text { secundária }\end{array}$ \\
\hline cipó-cravo & & & & Mata primária \\
\hline embaúba & Cecropia glaziovi Snethl. & Árvore & $\mathrm{E}$ & Ruderal \\
\hline
\end{tabular}




\begin{tabular}{|c|c|c|c|c|}
\hline Nome popular & Nome científico & Hábito & $\begin{array}{l}\text { Oc } \\
\text { or. }\end{array}$ & Habitat \\
\hline embaúba & Cecropia pachystachya Trèc. & Árvore & $\mathrm{E}$ & $\begin{array}{l}\text { Mata fluvial } \\
\text { de encosta }\end{array}$ \\
\hline embaúba & Cecropia sp & Árvore & $\mathrm{E}$ & $\begin{array}{l}\text { Mata } \\
\text { secundária }\end{array}$ \\
\hline erva-de-bicho & Polygonum cf. pontudo & Herbácea & $\mathrm{E}$ & Brejo(Várzea) \\
\hline erva-de-bicho & Polygonum cf. pontudo & Herbácea & $\mathrm{E}$ & Mata ciliar \\
\hline erva-de-são-joão & Ageratum conyzoides L. & Herbácea & E & Ruderal \\
\hline $\begin{array}{l}\text { erva-de-sete-sang } \\
\text { rias }\end{array}$ & $\begin{array}{l}\text { Cuphea cartaginensis (Jacq. ) } \\
\text { Macbr. }\end{array}$ & Herbácea & $\mathrm{E}$ & Ruderal \\
\hline $\begin{array}{l}\text { erva-de-sete-sang } \\
\text { rias }\end{array}$ & $\begin{array}{l}\text { Cuphea cartaginensis (Jacq. ) } \\
\text { Macbr. }\end{array}$ & Herbácea & $\mathrm{E}$ & Capoeira \\
\hline erva-de-santa-maria & Chenopodium ambrosioides L. & Herbácea & $\mathrm{E}$ & Ruderal \\
\hline erva-de-santa-maria & Chenopodium ambrosioides L. & Herbácea & $\mathrm{C}$ & \\
\hline espinheira-santa 1 & $\begin{array}{l}\text { Sorocea bonplandii (Baill.) W. } \\
\text { C. Burguer }\end{array}$ & Árvore & $\mathrm{E}$ & Capoeira \\
\hline espinheira-santa 1 & $\begin{array}{l}\text { Zollernia ilicifolia (Brongn.) } \\
\text { Vog }\end{array}$ & Árvore & $\mathrm{E}$ & Capoeira \\
\hline espinheira-santa 1 & $\begin{array}{l}\text { Zollernia ilicifolia (Brongn.) } \\
\text { Vog }\end{array}$ & & & $\begin{array}{l}\text { Mata fluvial } \\
\text { de encosta }\end{array}$ \\
\hline espinheira-santa 1 & $\begin{array}{l}\text { Zollernia ilicifolia (Brongn.) } \\
\text { Vog }\end{array}$ & & & Brejo(Várzea) \\
\hline fedegoso & Senna occidentalis (L.) Link & Herbácea & $\mathrm{E}$ & Capoeira \\
\hline fedegoso & Senna occidentalis (L.) Link & Herbácea & $\mathrm{E}$ & Ruderal \\
\hline fedegoso & Senna sp & Arbusto & $\mathrm{E}$ & Ruderal \\
\hline guaçatonga & Casearia sylvestris Sw. & Árvore & $\mathrm{E}$ & Ruderal \\
\hline guaçatonga & Casearia sylvestris Sw. & Árvore & $\mathrm{E}$ & $\begin{array}{l}\text { Mata } \\
\text { secundária }\end{array}$ \\
\hline guaçatonga & Casearia sylvestris Sw. & Árvore & $\mathrm{E}$ & Mata ciliar \\
\hline guaco & $\begin{array}{l}\text { Clematis dioica var. brasiliana } \\
\text { (D.C.) }\end{array}$ & Liana(Cipó) & $\mathrm{E}$ & $\begin{array}{l}\text { Mata } \\
\text { secundária }\end{array}$ \\
\hline guaco & Mikania sp. & Trepadeira & $\mathrm{E}$ & Capoeira \\
\hline guaco & Mikania sp. & Trepadeira & $\mathrm{E}$ & $\begin{array}{l}\text { Mata fluvial } \\
\text { de encosta }\end{array}$ \\
\hline guaco & Mikania sp. & Trepadeira & $\mathrm{E}$ & Brejo(Várzea) \\
\hline jaborandi 1 & Baccharis cassinefolia DC. & Arbusto & $\mathrm{E}$ & Brejo(Várzea) \\
\hline jaborandi 1 & Baccharis cassinefolia DC. & Arbusto & $\mathrm{E}$ & Capoeira \\
\hline
\end{tabular}




\begin{tabular}{|c|c|c|c|c|}
\hline Nome popular & Nome científico & Hábito & $\begin{array}{l}\text { Oc } \\
\text { or. }\end{array}$ & Habitat \\
\hline jaborandi 1 & Baccharis cassinefolia DC. & Arbusto & $\mathrm{E}$ & $\begin{array}{l}\text { Mata fluvial } \\
\text { de encosta }\end{array}$ \\
\hline jatobá & $\begin{array}{l}\text { Hymenaea courbaril L. var. - } \\
\text { altissima }\end{array}$ & Árvore & $E$ & \\
\hline $\begin{array}{l}\text { melão-de-são-caet } \\
\text { ano }\end{array}$ & Momordica charantia L. & Trepadeira & $E$ & Ruderal \\
\hline pata-de-vaca & Bauhinia sp. & Árvore & $\mathrm{E}$ & $\begin{array}{l}\text { Mata } \\
\text { secundária }\end{array}$ \\
\hline pata-de-vaca & Bauhinia sp. & Árvore & $\mathrm{E}$ & Capoeira \\
\hline pata-de-vaca & Bauhinia sp. & Árvore & $\mathrm{C}$ & \\
\hline picão & Bidens pilosa $\mathrm{L}$. & Herbácea & $E$ & Ruderal \\
\hline quebra-pedra 1 & Phyllanthus niruri L. & Herbácea & $\mathrm{E}$ & Ruderal \\
\hline salssaparrilha 1 & $\begin{array}{l}\text { Smilax cf subsessiliflora } \\
\text { Duhamel }\end{array}$ & Liana(Cipó) & $\mathrm{E}$ & Brejo (Várzea) \\
\hline salssaparrilha 1 & Smilax elastica Griseb. & Liana(Cipó) & $\mathrm{E}$ & Brejo (Várzea) \\
\hline salssaparrilha 1 & Smilax elastica Griseb. & Liana(Cipó) & E & Capoeira \\
\hline salssaparrilha 1 & Smilax elastica Griseb. & Liana(Cipó) & $\mathrm{E}$ & $\begin{array}{l}\text { Mata fluvial } \\
\text { de encosta }\end{array}$ \\
\hline salssaparrilha 1 & Smilax fluminensis Steud. & Trepadeira & $\mathrm{E}$ & \\
\hline sassafrás 1 & $\begin{array}{l}\text { Ocotea cf. odorifera (Vell.) } \\
\text { Rohwer }\end{array}$ & Árvore & $\mathrm{E}$ & $\begin{array}{l}\text { Mata } \\
\text { secundária }\end{array}$ \\
\hline sene & $\begin{array}{l}\text { Senna multijuga (Rich.) Irwin \& } \\
\text { Barneby }\end{array}$ & Árvore & $\mathrm{E}$ & Ruderal \\
\hline
\end{tabular}

\subsubsection{As áreas do manejo tradicional}

A amostra dos extratores e produtores de plantas medicinais da região do Vale do Ribeira utiliza vários tipos de formação da Mata Atlântica para obter as plantas medicinais comercializadas. Eles, especialmente um dos guias principais (ver 5.2.3. Aspectos dos guias principais), têm um sistema próprio de classificação dos tipos de formação da Mata Atlântica. As categorias desses tipos de formação classificadas pelos entrevistados estão apresentados abaixo: 
- Mata pluvial de encosta: formação vegetal típica de locais com maior altitude e com presença de declividades (morros); também chamada, pelos extratores de mata primária, fechada ou virgem; apresenta vegetais de maior porte (arbóreas muito altas);

- Mata ciliar: formação vegetal que se encontra nas margens dos rios até cerca de 50 metros para o interior;

- Mata inundảvel: formação vegetal encontrada imediatamente após a mata ciliar, freqüentemente alagada, sendo por isso também conhecida como várzea;

- Mata secundária: formação vegetal de grande porte, em estágio médio de regeneração, caracterizada, porém, pela presença de espécies pioneiras, que não ocorrem na chamada mata primária;

- Restinga: formação vegetal típica da orla marítima, regiões de beira mar onde o solo apresenta alta proporção de areia; é também definida em função da altitude, denominando-se "de baixada";

- Capoeira: formação vegetal de médio porte em processo de recomposição, aparecendo em várias altitudes e em declividades variáveis do terreno;

- Brejo (várzea): formação vegetal de regiões alagadas; pode ser confundida com mata inundável, que, porém, ocorre mais para o interior;

- Ruderais: vegetais invasores de áreas abertas como pastos, beiras de estradas, terrenos abandonados, roças, bananais, etc. Essa definição também foi fornecida pelos entrevistados e coincide com a definição usada na Botânica Sistemática.

Em uma ordem decrescente, as três categorias dessas formações vegetais que tiveram maior frequiência nas citações foram: mata pluvial de encosta, ruderais e capoeira. Isso está apresentado na tabela 7, assim como todas as outras ocorrências citadas. 
Tabela 7 - Locais de extração e citações correspondentes, de acordo com os depoimentos da amostra de extratores e produtores de plantas medicinais da região do Vale do Ribeira, SP.

\begin{tabular}{l|c}
\hline \multicolumn{1}{c|}{ Local de Extração } & Citações \\
\hline Mata pluvial de encosta & 72 \\
\hline Ruderais & 68 \\
\hline Capoeira & 54 \\
\hline Sem informação & 13 \\
\hline Brejo (várzea) & 21 \\
\hline Mata secundária & 10 \\
\hline Restinga & 7 \\
\hline Mata ciliar & 3 \\
\hline Mata inundável & 3 \\
\hline Dunas & 2 \\
\hline Outros locais & 2 \\
\hline
\end{tabular}

Os extratores e produtores, principalmente um dos guias principais, fizeram várias considerações sobre a interferência dos fatores ambientais na produtividade das espécies medicinais, como pode ser observado nos seguintes depoimentos dados pelo Sr. B:

"Quando em mata primária têm uma única vida; capoeira é o que lucra mais. É na capoeira que a gente encontra as plantas que têm bolão." ( $\mathrm{O}$ entrevistado quis dizer que as plantas apresentam maior produtividade em capoeira onde são encontradas as maiores concentrações de reboleira, ou seja, de aglomerados das plantas).

"A encosta, cerca de 900 metros (de altitude) diminui o tamanho das folhas e elas ficam mais amareladas e duras. Muda também a cor da casca; a altitude, a declividade, a quantidade de $\mathrm{O}_{2}$, e a umidade interferem na altura, no diâmetro e na copagem (o entrevistado se referiu ao tamanho e a densidade da copa das árvores), pois há maior 
A localização das plantas medicinais está correlacionada com um perfil de distribuição, segundo a amostra dos extratores e produtores. A definição das áreas que compõem esse perfil de distribuição das plantas medicinais na região do Vale do Ribeira está associado principalmente à altitude e à declividade das diversas regiões. As três regiões e suas respectivas definições fornecidas pelos entrevistados serão descritas a seguir e ilustradas na figura 3 :

1. Área central: engloba áreas dos municípios de Registro, Jacupiranga e Miracatu com até 100 metros de altitude, onde se encontra o maior número de espécies medicinais;

2. Área mais ao norte (ou de encosta): engloba principalmente áreas dos municípios de Eldorado, Sete Barras e Juquiá com até 800 metros de altitude e onde ocorrem espécies de altitude; apresenta acesso mais difícil;

3. Área mais ao sul (ou de restinga/litoral): engloba a região de Pariquera-Açu, Cananéia, Iguape, e Ilha Comprida com até 15 metros de altitude e com espécies típicas dessa região. 


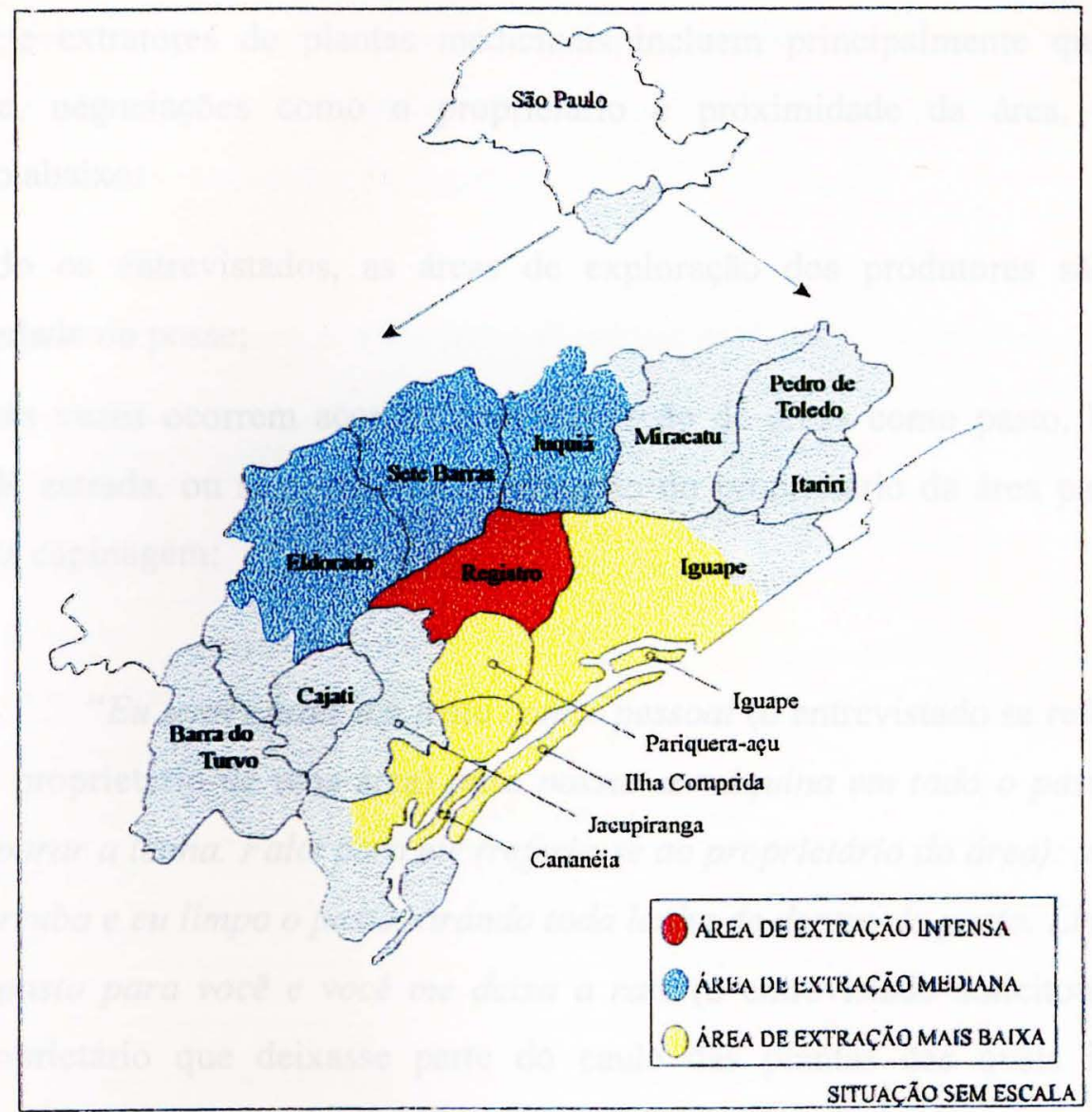

Figura 3 - Localização das áreas de extração das plantas medicinais citadas pela amostra de extratores e produtores da região do Vale do Ribeira, SP. Fonte: BORN, 1997.

A área central, área de extração mais intensa e onde se encontra maior concentração de extratores e produtores, engloba o município de Registro, que polariza a economia regional. Por isso, nesse município se encontram o maior centro urbano, quase toda as representações do governo e o maior potencial agrícola, do comércio e de serviços da região (ENGECORPS \& GOVERNO DO ESTADO DE SÃO PAULO, 1992).

Além disso, conforme apresentado no item 3.3 - Plantas medicinais, essa região 
foi uma das duas escolhidas para se realizarem os estudos sobre manejo sustentável de espécies medicinais da Mata Atlântica, no âmbito do projeto Da mata à casa (BORN, 1997; PAVAN, 1999).

Os aspectos que determinam a escolha das áreas de extração pela amostra dos produtores e extratores de plantas medicinais incluem principalmente questões de propriedade, negociações como o proprietário e proximidade da área, conforme apresentado abaixo:

- Segundo os entrevistados, as áreas de exploração dos produtores são de sua propriedade ou posse;

- Algumas vezes ocorrem acordos para utilização de áreas como pasto, bananal e beira de estrada, ou seja, há uma autorização do proprietário da área para que se faça sua capinagem:

"Eu tentei fazer um trato com o pessoal (o entrevistado se referia ao proprietário de uma área) para passar a máquina em todo o pasto $e$ separar a lenha. Falei para ele (referia-se ao proprietário da área): você derruba e eu limpo o pasto, tirando toda lenha de dentro do pasto. Limpo o pasto para você e você me deixa a raiz (o entrevistado solicitou ao proprietário que deixasse parte do caule das plantas das quais iria, posteriormente, extrair material vegetal) para que ela brote e eu continue fazendo a extração. Não deixo mais formar água. Tudo bem. Está lá, o pasto brotou e está a coisa mais maravilhosa, e eu continuo tirando. Este foi o melhor trabalho com ele para não destruir, nem eu ir mais longe para buscar o produto.". (Sr. B)

- Em geral, os entrevistados alegam não realizar extração em mata virgem apesar de citarem e confirmarem a comercialização de espécies que, segundo eles, só são encontradas neste tipo de formação vegetal;

- Procuram explorar áreas próximas a sua região domiciliar, entretanto, na escassez ou falta de determinada espécie vão se afastando de acordo com a necessidade. 
Segundo os entrevistados, os acordos com os proprietários das áreas de extração têm enfrentado dificuldades por causa da crescente demanda do mercado de plantas medicinais. Eles informaram que antes era fácil conseguir a permissão do proprietário, mas, recentemente, estes têm feito o seguinte questionamento: "Dá dinheiro?".

A tabela 8 apresenta as plantas mais citadas, os indicadores ambientais da presença das plantas e as respectivas citações, segundo a amostra dos extratores e produtores de plantas medicinais da região do Vale do Ribeira, SP.

Tabela 8 - Plantas mais citadas, seus indicadores ambientais e respectivas citações

\begin{tabular}{l|l|c}
\hline \multicolumn{1}{c|}{ Nome popular } & \multicolumn{1}{c|}{ Indicadores do potencial } & Citações \\
\hline arrueira & Nada, dá em todo lugar & 4 \\
\hline assa-peixe & Nada, dá em todo lugar & 2 \\
\hline assa-peixe & Sem informação & 1 \\
\hline cana-do-brejo & Sem informação & 2 \\
\hline cana-do-brejo & Umidade local & 2 \\
\hline capiá-rosário & Sem informação & 1 \\
\hline capiá-rosário & Tipo de solo & 1 \\
\hline capiá-rosário & Umidade local & 2 \\
\hline carobinha 1 & Altitude & 1 \\
\hline carobinha 1 & Clima local & 1 \\
\hline carobinha 1 & Sem informação & 1 \\
\hline carqueja & Clima local & 1 \\
\hline carqueja & Outros & 1 \\
\hline carqueja & Sem informação & 2 \\
\hline carqueja & Tipo de solo & 1 \\
\hline chapéu-de-couro & Clima local & 1 \\
\hline chapéu-de-couro & Outros & 1 \\
\hline chapéu-de-couro & Umidade local & 1 \\
\hline cipó-cabeludo & Clima local & 2 \\
\hline cipó-cabeludo & Outros & 1 \\
\hline cipó cabeludo & Sem informação & 1 \\
\hline cipó-cravo & Altitude & 1 \\
\hline emó-cravo & Sem informaçáo & 1 \\
\hline & Nada, dá em todo lugar & 1 \\
\hline
\end{tabular}




\begin{tabular}{|c|c|c|}
\hline Nome popular & Indicadores do potencial & Citações \\
\hline embaúba & Outros & 1 \\
\hline erva-de-bicho & Umidade local & 3 \\
\hline erva-de-santa-maria & Altitude & 1 \\
\hline erva-de-santa-maria & Luminosidade (claro ou escuro) & 1 \\
\hline erva-de-santa-maria & Nada, dá em todo lugar & 1 \\
\hline erva-de-santa-maria & Umidade local & 1 \\
\hline erva-de-são-joão & Altitude & 1 \\
\hline erva-de-são-joão & Nada, dá em todo lugar & 2 \\
\hline erva-de-sete-sangrias & Sem informação & 3 \\
\hline erva-de-sete-sangrias & Umidade local & 1 \\
\hline espinheira-santa 1 & Clima local & 1 \\
\hline espinheira-santa 1 & Declividade & 1 \\
\hline espinheira-santa 1 & Outros & 1 \\
\hline espinheira-santa 1 & Sem informação & 1 \\
\hline fedegoso & Sem informação & 3 \\
\hline guaçatonga & Clima local & 1 \\
\hline guaçatonga & Declividade & 1 \\
\hline guaçatonga & Sem informação & 4 \\
\hline guaco & Clima local & 2 \\
\hline guaco & Nada, dá em todo lugar & 1 \\
\hline guaco & Sem informação & 2 \\
\hline jaborandi 1 & Altitude & 1 \\
\hline jaborandi 1 & Sem informação & 2 \\
\hline jatobá & Altitude & 2 \\
\hline jatobá & Sem informação & 2 \\
\hline melão-de-são-caetano & Nada, dá em todo lugar & 1 \\
\hline melão-de-são-caetano & Sem informação & 3 \\
\hline pata-de-vaca & Clima local & 1 \\
\hline pata-de-vaca & Outros & 1 \\
\hline pata-de-vaca & Sem informação & 2 \\
\hline picão & Nada, dá em todo lugar & 2 \\
\hline quebra-pedra 1 & Nada, dá em todo lugar & 3 \\
\hline quebra-pedra 1 & Nada, dá em todo lugar & 1 \\
\hline quebra-pedra 1 & Sem informação & 3 \\
\hline salssaparrilha 1 & Clima local & 1 \\
\hline
\end{tabular}




\begin{tabular}{l|l|c}
\hline \multicolumn{1}{c|}{ Nome popular } & \multicolumn{1}{c|}{ Indicadores do potencial } & Citações \\
\hline salssaparrilha 1 & Sem informação & 1 \\
\hline salssaparrilha 1 & Tipo de solo & 1 \\
\hline sassafrás 1 & Outros & 2 \\
\hline sassafrás 1 & Sem informação & 1 \\
\hline sene & Clima local & 2 \\
\hline sene & Nada, dá em todo lugar & 1 \\
\hline sene & Sem informação & 3 \\
\hline
\end{tabular}

Com relação aos indicadores ambientais da presença das plantas, os entrevistados usam critérios para indicar a escolha do local de extração das plantas, principalmente para extrair aquelas que podem ocorrer em áreas diferentes. Os extratores e produtores elaboram tais critérios considerando a distância entre sua residência e a área de extração; a possibilidade de a planta e/ou de sua população se regenerar, e o. potencial da espécie na área, que é observado pela ocorrência de aglomerados de indivíduos de uma mesma espécie. Esses aglomerados são denominados de "bolões" ou reboleiras.

O potencial da presença das plantas em determinadas áreas é dependente dos seguintes fatores ambientais, segundo os entrevistados: altitude, declividade, umidade, temperaturas, tipo de solo predominante, condições de luminosidade, a presença de outras plantas consideradas indicadoras de condições especiais, principalmente, de nutrientes do solo, bem como a formação vegetal.

Eventualmente nenhum fator é observado pois a espécie medicinal considerada é muito comum e invasora na região ou é tão rara que não foi possível determinar suas necessidades nem, conseqüentemente, suas condições de ocorrência.

A tabela 9 apresenta os fatores observados para determinação do potencial das espécies medicinais com a respectiva freqüência de citação. Verifica-se nesta tabela que mais de um fator pode ser observado para cada planta, pois para as 244 citações de manejo tradicional os entrevistados forneceram 270 citações de fatores. Observa-se também na tabela referida que há considerável porcentual de plantas sobre as quais os entrevistados não têm informação a respeito de seu potencial. 
Tabela 9 - Fatores observados como indicadores ambientais da presença das plantas, segundo a amostra de extratores e produtores de plantas medicinais da região do Vale do Ribeira, SP

\begin{tabular}{l|c}
\hline \multicolumn{1}{c|}{ Fatores observados } & Citações \\
\hline Sem Informação & 74 \\
\hline Nada. É invasora. É praga, dá em todo lugar. & 43 \\
\hline Altitude & 35 \\
\hline Outros fatores & 25 \\
\hline Umidade local & 23 \\
\hline Declividade & 22 \\
\hline Clima local & 22 \\
\hline Nada. É rara ou está em extinção. & 8 \\
\hline Tipo de solo & 7 \\
\hline Copa das árvores & 5 \\
\hline Luminosidade (claro ou escuro) & 5 \\
\hline Espécies indicadoras & 3 \\
\hline
\end{tabular}

Verificou-se que a amostra dos extratores e produtores se preocupa com a periodicidade. Eles definem um período médio para retornar a cada área dependendo da planta a ser extraída. Há, portanto, correlação entre a periodicidade de extração da planta e a periodicidade de retorno à área de extração (gráficos 9 e 10). As tabelas $10 \mathrm{e}$ 11 resumem os totais das citações para a periodicidade de manejo das áreas e das plantas, respectivamente. A regeneração da parte extraída indica a periodicidade de extração da planta.

Os gráficos 9 e 10 mostram, também, que cerca de $49 \%$ das citações não observam nenhuma periodicidade de retorno às áreas de extração e $53 \%$ não observa nenhuma periodicidade em relação às plantas. Isso significa que o retorno para se extrair uma planta ou sua população em uma mesma área ocorre quando a planta é solicitada pelo cliente. 
Tabela 10 - Periodicidade de retorno às áreas de extração, segundo a amostra dos extratores e produtores de plantas medicinais da região do Vale do Ribeira, SP.

\begin{tabular}{l|c|c}
\hline $\begin{array}{c}\text { Periodicidade de retorno às } \\
\text { áreas de extração }\end{array}$ & \multicolumn{2}{c}{ Citações } \\
& $N^{0}$ & $\%$ \\
\hline \hline Não observa período & 118 & 49 \\
\hline De 6 em 6 meses & 47 & 19 \\
\hline Anualmente & 43 & 18 \\
\hline Sem informação & 28 & 11 \\
\hline Continuamente & 5 & 2 \\
\hline Outros períodos & 2 & 1 \\
\hline De 3 em 3 meses & 1 & 0 \\
\hline
\end{tabular}

Gráfico 9 - Periodicidade de retomo às áreas de extração

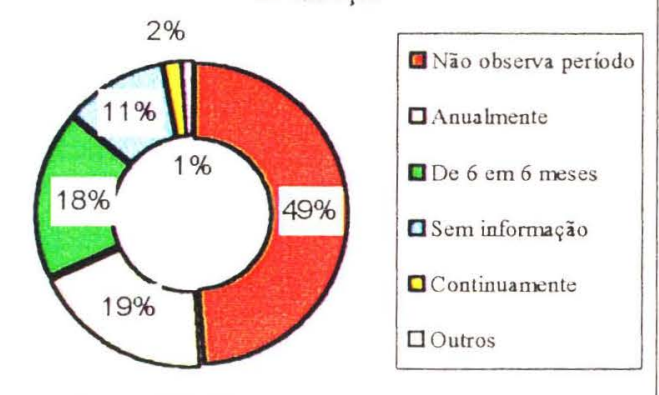

Tabela 11 - Periodicidade de extração das plantas e suas citações, segundo a amostra dos extratores e produtores de plantas medicinais da região do Vale do Ribeira, SP.

\begin{tabular}{l|c|c}
\hline $\begin{array}{c}\text { Periodicidade de Extração } \\
\text { das plantas medicinais }\end{array}$ & \multicolumn{2}{|c}{ Citações } \\
$\mathbf{N}^{\mathbf{0}}$ & $\mathbf{\%}$ \\
\hline \hline Não observa período & 130 & 53 \\
\hline Anualmente & 42 & 17 \\
\hline de 6 em 6 meses & 36 & 15 \\
\hline Sem informação & 22 & 9 \\
\hline Continuamente & 6 & 2 \\
\hline Outros & 4 & 2 \\
\hline de 3 em 3 meses & 4 & 2 \\
\hline
\end{tabular}

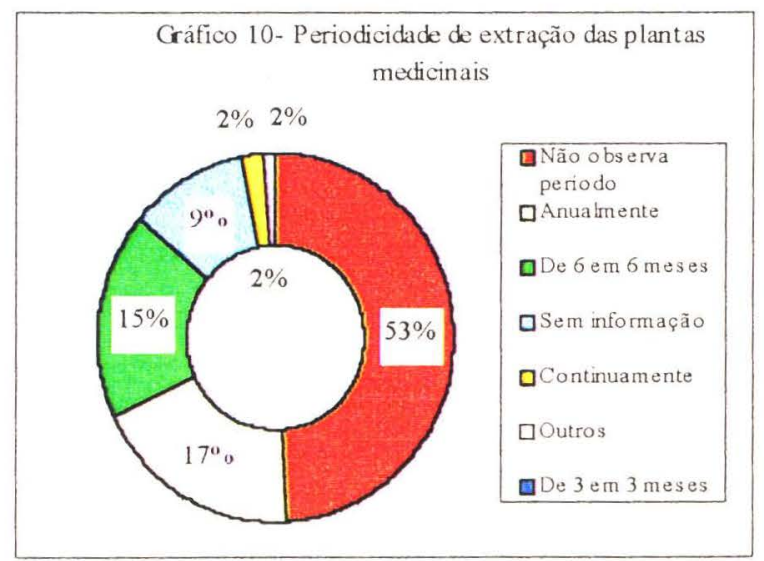




\subsubsection{O manejo tradicional}

Os extratores e produtores entrevistados forneceram informações pormenorizadas que possibilitaram o cadastramento no banco de dados de 244 fichas de manejo tradicional para as 148 plantas citadas pelos entrevistados.

As partes extraídas das plantas variam de acordo com a planta considerada, sendo que várias delas fornecem mais de uma parte para a comercialização. As partes extraídas estão apresentadas na tabela 12 , bem como suas respectivas citações. Observase nesta tabela que as partes mais extraidas são: ramo, planta toda, parte aérea, casca do caule e raiz. Elas representam cerca de $77 \%$ do total das citações.

Tabela 12 - As partes extraídas das plantas e suas respectivas citações pela amostra dos extratores e produtores de plantas medicinais da região do Vale do Ribeira, SP.

\begin{tabular}{l|c}
\hline \multicolumn{1}{c|}{ Partes extraídas } & Citą̧̃̃es \\
\hline Ramo & 51 \\
\hline Planta toda & 50 \\
\hline Parte aérea & 36 \\
\hline Casca do caule & 26 \\
\hline Raiz & 25 \\
\hline Folha & 15 \\
\hline Cipó & 12 \\
\hline Fruto & 7 \\
\hline Semente & 7 \\
\hline Resina & 5 \\
\hline Flor & 3 \\
\hline Lenho & 3 \\
\hline Óleo & 1 \\
\hline Outros & 1 \\
\hline Caule & 1 \\
\hline Látex & 1 \\
\hline
\end{tabular}

A amostra dos extratores e produtores citou várias formas detalhadas de extração 
das plantas manejadas. Tais formas foram agrupadas em categorias diferentes para facilitar a organização, a quantificação e a correlação dos dados obtidos. A seguir, serão apresentadas, essas categorias e uma breve descrição de cada categoria das técnicas de extração citadas pelos entrevistados:

- $\quad$ Corte de todo indivíduo: extração de toda a planta;

- Podas periódicas dos ramos: poda de parte dos ramos ou de todos os ramos da planta, em determinados períodos;

- $\quad$ Podas periódicas da parte aérea: poda da parte aérea da planta, deixando parte do caule ou retirando totalmente o caule, deixando apenas as raízes, em determinados periodos;

- Descasca de 50\% da planta unilateralmente: descascamento de um dos lados do caule, preservando-se o outro, que poderá ser retirado no período de extração subseqüente;

- Recolhimento do chão: coleta do órgão vegetal, geralmente frutos e sementes, após sua queda da planta.

Há correlação direta entre a forma de extração empregada e a parte extraída da planta. Como pode ser verificado na tabela 13, foram citadas as seguintes correlações entre a forma e a parte extraída das plantas:

- Para a extração do ramo, a principal técnica utilizada é a poda periódica do ramo;

- Para a extração da casca do caule, a técnica mais empregada é descascar um lado do caule, geralmente aquele voltado para o nascente;

- Para a extração da planta toda e a extração de raízes, determina-se principalmente o corte de todo o indivíduo;

- Para a obtenção de frutos e de sementes, recomenda-se o recolhimento do chão;

- Para a extração de exsudatos, como látex e resinas, utiliza-se, sobretudo, a técnica de sangrias, que compreende a realização de cortes no caule das plantas para provocar a liberação dos exsudatos. 
Tabela 13 Correlações entre as partes extraídas e as formas de manejo das plantas citadas pela amostra dos extratores e produtores de plantas medicinais da região do Vale do Ribeira, SP.

\begin{tabular}{|c|c|c|c|}
\hline Parte & Forma de & \multicolumn{2}{|c|}{ Citações } \\
\hline Extraida & Manejo & $\mathbf{N}^{\mathbf{q}}$ & $\%$ \\
\hline Casca do caule & Corte de todo o indivíduo & 4 & 15,4 \\
\hline Casca do caule & Descasca $50 \%$ da planta unilateralmente & 22 & 84,6 \\
\hline Caule & Corte de todo o indivíduo & 1 & 100 \\
\hline Cipó & Corte de todo o indivíduo & 1 & 8,3 \\
\hline Cipó & Outros & 2 & 16,7 \\
\hline Cipó & Podas periódicas da parte aérea & 9 & 75 \\
\hline Flor & Podas periódicas do ramo & 3 & 100 \\
\hline Folha & Corte de todo o indivíduo & 5 & 33,4 \\
\hline Folha & Outros & 8 & 53,3 \\
\hline Folha & Podas periódicas do ramo & 2 & 13,3 \\
\hline Fruto & Outros & 2 & 28,6 \\
\hline Fruto & Podas periódicas do ramo & 2 & 28,6 \\
\hline Fruto & Recolhimento do chão & 3 & 42,8 \\
\hline Látex & Sangrias & 1 & 100 \\
\hline Lenho & Corte de todo o indivíduo & 2 & 66,7 \\
\hline Lenho & Outros & 1 & 33,3 \\
\hline Óleo & Sangrias & 1 & 100 \\
\hline Outros & Corte de todo o indivíduo & 1 & 100 \\
\hline Parte aérea & Corte de todo o indivíduo & 1 & 2,8 \\
\hline Parte aérea & Podas periódicas da parte aérea & 35 & 97,2 \\
\hline Planta toda & Corte de todo o indivíduo & 50 & 100 \\
\hline Raiz & Corte de todo o indivíduo & 22 & 88 \\
\hline Raiz & Outros & 3 & 22 \\
\hline Ramo & Podas periódicas do Ramo & 51 & 100 \\
\hline Resina & Outros & 1 & 20 \\
\hline Resina & Sangrias & 4 & 80 \\
\hline Semente & Outros & 1 & 14,3 \\
\hline Semente & Recolhimento do Chão & 6 & 85,7 \\
\hline
\end{tabular}

Em relação à quantidade de material extraído por planta ou por área de extração, os extratores e produtores entrevistados alegaram não observar esse aspecto e o que determina quanto eles extraem de dada planta é o pedido de seus clientes. 
De maneira geral, foram obtidas poucas informações à respeito da intensidade de extração de material por planta e por área. As técnicas mais elaboradas foram fornecidas por um dos guias principais. Para extrair ramos e folhas de árvores, ele procura indivíduos adultos e viçosos da planta desejada e poda todos os seus galhos, realizando o "rebaixamento da planta" para facilitar a extração subseqüente e induzir maior crescimento dos galhos. A altura da poda é aquela até onde houver folhas, procurando preservar os "olhos da planta" (isto é, as gemas de crescimento lateral), em determinado período. O entrevistado acrescenta que, à medida que a planta vai sendo podada, ela vai “engordando" (crescimento lateral), pois sua técnica otimiza a produtividade da planta. Ele concluiu o seguinte:

Para extrair a casca do caule da planta, ele descasca em uma metade (lado) do caule até onde alcança, cerca de 1,8 metro de altura. $O$ guia principal acrescenta ainda que mesmo tomando o máximo de cuidado, a planta pode morrer.

Já para raízes, o entrevistado ressalta que são poucas as plantas que, de fato, conseguem se regenerar, a maioria morre após a extração. Portanto, ele admite que para a obtenção de raízes e de casca de caule, apesar de indicar sua retirada parcial, é mais interessante e compensatório, procurar aproveitar todo o indivíduo, para fins apropriados, e manejar a população da planta.

"O guanandi, por exemplo: a casca desta espécie não repõe. Mesmo se ficar uma parte, ela morre. Diferente do ipê que repõe". (Sr. B)

A técnica usada para derrubar a árvore compreende a retirada da terra em volta das raízes de maneira que o próprio peso da árvore promova sua queda. Uma das plantas em que o entrevistado emprega essa técnica, quando possível, é a cânfora.

Uma das técnicas de manejo tradicional muito interessante e empregada pelo entrevistado é a usada para extrair raízes. Ele extrai raízes da planta sassafráz, retirando partes da planta "mãe" ("planta adulta e viçosa") até que ela brote. Antes disso, retira somente uma raiz. Quando o broto atinge uma altura em torno de 2 metros, ele começa a podar o broto, visando sua "engorda" (crescimento lateral) e não o crescimento em 
altura. As podas de "engorda" chegam a demorar 4 anos para dar resultado. O entrevistado concluiu dizendo:

“Nesse momento (referia-se ao final dos 4 anos necessários para empregar a técnica explicada acima), pode trabalhar sem medo com a $m \tilde{a} e^{\prime \prime}$ (Sr. B)

A amostra dos extratores e produtores entrevistada indicou vários aspectos na planta (indivíduo) que determinam ou não a escolha da planta desejada para extração. A tabela 14 apresenta os elementos levantados com suas respectivas citações. Verifica-se nessa tabela que os entrevistados fizeram 477 citações de aspectos considerados para a escolha do indivíduo. Isso significa que mais de um elemento pode ser considerado pelos entrevistados para orientá-los na determinação do indivíduo ou da população da planta a ser manejada. Nenhum aspecto, entretanto, é observado para a extração de 62 plantas, ou seja, cerca de $42 \%$ do total das plantas citadas. Elas são submetidas ao manejo tradicional sem nenhum critério para escolha.

O estágio de desenvolvimento (estágio adulto da planta) e a viçosidade da planta são os principais aspectos considerados pelos extratores e produtores entrevistados para selecionar as plantas (indivíduos e população) a serem manejadas. Esses dois aspectos indicam alta produtividade, ou seja, os entrevistados procuram escolher as plantas mais "velhas" e "cheias" ou com mais "massa", pois são maiores a produção e a possibilidade de regeneração satisfatória da planta. 
Tabela 14 - Aspectos observados na planta para selecionar o indivíduo ou a população a ser submetida ao manejo tradicional das plantas citadas pela amostra dos extratores e produtores de plantas medicinais da região do Vale do Ribeira, SP.

\begin{tabular}{l|c}
\hline \multicolumn{1}{c|}{ Aspectos observados na planta } & Citações \\
\hline Estágio de desenvolvimento & 102 \\
\hline Viçosidade & 92 \\
\hline Nada, não observa. & 83 \\
\hline Processo de recuperação & 39 \\
\hline Diâmetro & 37 \\
\hline Floração & 40 \\
\hline Altura & 36 \\
\hline Sem informação & 12 \\
\hline Frutificação & 11 \\
\hline Idade do órgão & 9 \\
\hline
\end{tabular}

Na tabela 15, verifica-se que há correlação entre a parte extraída e os aspectos observados. Nota-se, portanto, que para as 5 partes extraidas mais citadas pelos entrevistados, os aspectos observados com maior número de citações são diâmetro, processo de recuperação e altura, para casca do caule, e viçosidade, para parte aérea e ramo. Para a planta toda e raiz, os entrevistados não observam nenhum aspecto determinante da extração do material vegetal.

Tabela 15 - Correlação entre a parte extraída e os aspectos observados para selecionar as plantas, segundo a amostra de extratores e produtores de plantas medicinais da região do Vale do Ribeira, SP.

\begin{tabular}{l|l|c}
\multicolumn{1}{c|}{ Parte extraida } & \multicolumn{1}{c}{ Aspectos observados } & Citações \\
\hline Casca do caule & Diâmetro & 18 \\
\hline Casca do caule & Processo de recuperação & 18 \\
\hline Casca do caule & Altura & 18 \\
\hline Casca do caule & Estágio de desenvolvimento & 6 \\
\hline Casca do caule & Nada, não observa. & 4 \\
\hline Casca do caule & Viçosidade & 1 \\
\hline Parte aérea & Viçosidade & 18 \\
\hline Parte aérea & Estágio de desenvolvimento & 16 \\
\hline Parte aérea & Floração & $\mathbf{8}$ \\
\hline Parte aérea & Nada, não observa. & 6 \\
\hline Parte aérea & Idade do órgão & 2 \\
\hline
\end{tabular}




\begin{tabular}{l|l|c}
\hline \multicolumn{1}{c|}{ Parte extraída } & \multicolumn{1}{c}{ Aspectos observados } & Citações \\
\hline Casca do caule & Diâmetro & 18 \\
\hline Parte aérea & Coloração & 1 \\
\hline Parte aérea & Parte aérea & 1 \\
\hline Parte aérea & Processo de recuperação & 1 \\
\hline Parte aérea & Diâmetro & 21 \\
\hline Planta toda & Nada, não observa. & 14 \\
\hline Planta toda & Estágio de desenvolvimento & 12 \\
\hline Planta toda & Viçosidade & 5 \\
\hline Planta toda & Densidade populacional & 4 \\
\hline Planta toda & Sem informação & 2 \\
\hline Planta toda & Coloração & 2 \\
\hline Planta toda & Ausência de ácaros (pulgões) & 1 \\
\hline Planta toda & Floração & 19 \\
\hline Raiz & Nada, não observa. & 6 \\
\hline Raiz & Estágio de desenvolvimento & 4 \\
\hline Raiz & Processo de recuperação & 26 \\
\hline Ramo & Viçosidade & 17 \\
\hline Ramo & Estágio de desenvolvimento & 14 \\
\hline Ramo & Floração & 9 \\
\hline Ramo & Altura & 9 \\
\hline Ramo & Processo de recuperação & 5 \\
\hline Ramo & Sem informação & 3 \\
\hline Ramo & Nada, não observa & 2 \\
\hline Ramo & Idade do órgão & 2 \\
\hline Ramo & Diâmetro &
\end{tabular}

Em relação ao período do dia para a extração das plantas, os extratores e produtores entrevistados recomendaram principalmente o período da manhã, com 143 citações, ou seja com 58,4\% do total, conforme mostra o gráfico 11 .

Gráfico 11- Períodos do dia para a extração de plantas medicinais

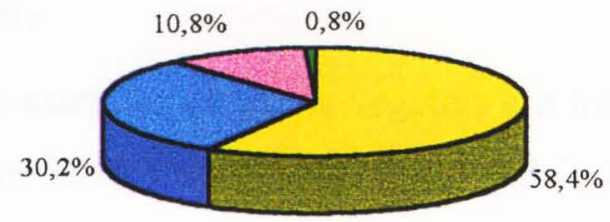

\begin{tabular}{|l|}
\hline$\square$ Manhã \\
$\square$ Qualquer \\
$\square$ S/ Informação \\
$\square$ Tarde \\
\hline
\end{tabular}


Os entrevistados recomendam que a coleta de folhas, flores e da planta toda deve ser realizada no período matutino, para que não haja alteração de coloração do material vegetal durante o processo de beneficiamento. Cascas, raízes, lenho, cipós e frutos podem ser coletados em qualquer horário do dia. Além do período do dia, os entrevistados determinaram também que a coleta de qualquer material vegetal deve ser realizada em dias secos, ou seja, não chuvosos e com baixa umidade relativa do ar.

No que diz respeito à época de extração, os entrevistados não levam em consideração esta questão para a maioria das plantas citadas, ou seja, 86 plantas (58\%). As plantas são extraídas em qualquer época do ano. Os pedidos dos compradores são os determinantes da época da extração. O gráfico 12, a seguir, ilustra essa situação.

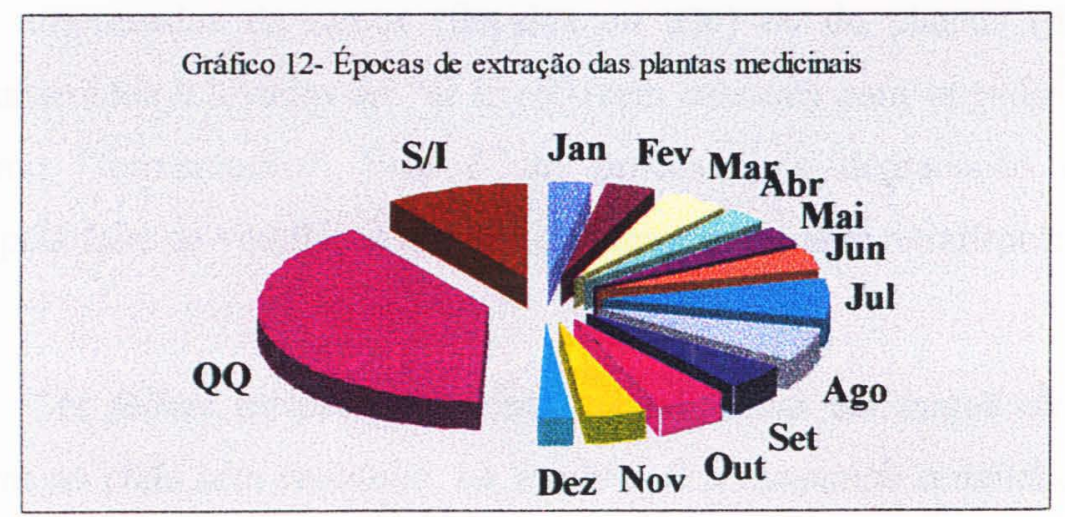

Ainda, segundo os entrevistados, os períodos em que eles recebem maior e menor número de pedidos são em junho-julho e em janeiro-fevereiro, respectivamente.

Após a extração, as partes vegetais são transportadas do local de extração para a estação de beneficiamento o mais rápido possível, visando a diminuição das alterações do material vegetal extraído, principalmente a coloração. Isso pode ser observado no seguinte depoimento: 
"A planta fica preta... Tudo de uma árvore medicinal fermenta porque ela tem alcalóide. O corpo dela (referia-se à planta) produz uma febre porque ela por si mesma aumenta a temperatura. Se ela fermentou pode jogar fora... É como você entrar em uma cama e colocar vários cobertores em cima de você, dá um aquecimento. É a mesma coisa. Você faz um feixe dela e ao mesmo tempo ela, por si só, começa a esquentar. Ela tem um óleo que causa esse aquecimento. Tem que sair correndo para secar a planta e para não ter problema, a não ser que sejam feitos pequenos pacotes e deixe eles em pé, mesmo assim existe risco." (Sr. B)

Para cada parte extraída há formas de transporte indicadas. O transporte mais utilizado do local de extração ao local de beneficiamento são os chamados "feixes", que consistem em amontoados de ramos (floridos ou não) ou de plantas (planta toda) frouxamente amarrados e levados ao "ar livre" (sem ensacar) para impedir o processo designado como "fermentação". Este é um processo de degradação do vegetal desencadeado pela falta de ventilação e início de secagem durante o transporte.

"As folhas sempre para cima, de pé, como um buquê de flor, encosta no chão sem saquinho, na sombra, fica chupando a umidade do chão." (Sr. B)

Para o transporte de cascas, raízes, frutos, etc. há outras formas de transporte que estão resumidas de acordo com a freqüência de citação na tabela 16. Os sacos utilizados para o transporte do material extraído são preferencialmente de pano/tecido para não impedir a circulação do ar.

Tabela 16 - Formas de transporte das partes extraidas das plantas citadas pela amostra dos extratores e produtores de plantas medicinais da região do Vale do Ribeira, SP.

\begin{tabular}{l|l|c}
\hline \multicolumn{1}{c|}{ Parte extraída } & \multicolumn{1}{c}{ Forma de transporte } & Citações \\
\hline Casca do caule & Em pedaços ensacados & 25 \\
\hline Casca do caule & Em feixes ensacados & 1 \\
\hline Caule & Em pedaços ensacados & 1 \\
\hline Cipó & Em pedaços ensacados & 6 \\
\hline Cipó & Em feixes sem ensacar & 5 \\
\hline Cipó & Em feixes ensacados & 1 \\
\hline
\end{tabular}




\begin{tabular}{l|l|c}
\hline \multicolumn{1}{c|}{ Parte extraída } & \multicolumn{1}{|c}{ Forma de transporte } & Citações \\
\hline Flor & Em feixes sem ensacar & 3 \\
\hline Folha & Em feixes sem ensacar & 10 \\
\hline Folha & Em feixes ensacados & 5 \\
\hline Fruto & Em saquinhos & 5 \\
\hline Fruto & Em feixes ensacados & 1 \\
\hline Fruto & Outros & 1 \\
\hline Látex & Na latinha ou pote em que é recoihido & 1 \\
\hline Lenho & Em pedaços ensacados & 2 \\
\hline Lenho & Em feixes sem ensacar & 1 \\
\hline Óleo & Na latinha ou pote em que é recolhido & 1 \\
\hline Outros & Em saquinhos & 1 \\
\hline Parte aérea & Em feixes sem ensacar & 29 \\
\hline Parte aérea & Em feixes ensacados & 6 \\
\hline Parte aérea & Em pedaços ensacados & 1 \\
\hline Planta toda & Em feixes sem ensacar & 32 \\
\hline Planta toda & Em feixes ensacados & 15 \\
\hline Planta toda & Em saquinhos & 2 \\
\hline Planta toda & Em pedaços ensacados & 1 \\
\hline Raiz & Em pedaços ensacados & 18 \\
\hline Raiz & Em feixes sem ensacar & 5 \\
\hline Raiz & Em saquinhos & 2 \\
\hline Ramo & Em feixes sem ensacar & 44 \\
\hline Ramo & Em feixes ensacados & 5 \\
\hline Ramo & Sem Informação & 1 \\
\hline Resina & Na latinha ou pote em que é recolhida & 4 \\
\hline Resina & Em pedaços ensacados & 1 \\
\hline Semente & Em saquinhos & 7 \\
\hline & &
\end{tabular}

$\mathrm{Na}$ tabela 17, no anexo 4, estão apresentadas as técnicas detalhadas do manejo tradicional, a parte extraída das 27 plantas mais citadas pelos entrevistados.

\subsubsection{O beneficiamento e a comercialização}

O beneficiamento engloba os processos de triagem ou limpeza, de secagem, de fragmentação ou trituração do material vegetal extraído. Há diversas técnicas empregadas pela amostra dos extratores e produtores entrevistada para calcular o rendimento do material vegetal seco e triturado, para controlar a qualidade do material comercializado, embalar, armazenar e aspectos sobre a comercialização, para quem vende e faixas de preço. 
Para as 148 plantas citadas pelos entrevistados foram obtidas 244 fichas de beneficiamento, ou seja, o mesmo número de fichas de manejo tradicional obtidas. Do total das plantas citadas, 126 são vendidas secas $(85,1 \%), 18$ são vendidas frescas $(12,2 \%)$ e 4 podem ser vendidas secas ou frescas $(2,8 \%)$ (gráfico 13$)$.

Gráfico 13 - Plantas vendidas secas e frescas, segundo a amostra dos extratores e produtores de plantas medicinais da região do Vale do Ribeira, SP.

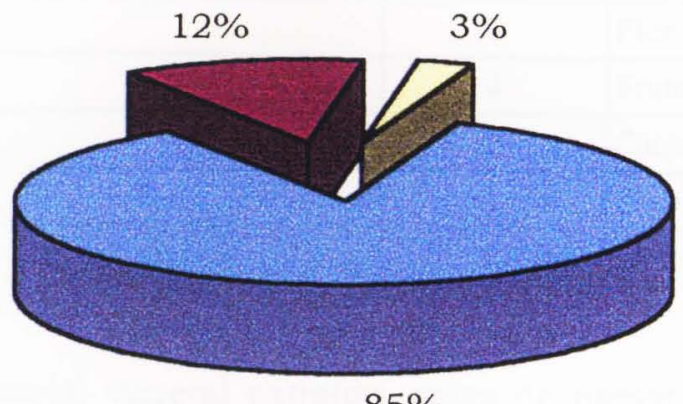

Plantas Vendidas Secas

Plantas Vendidas

Frescas

口Plantas Vendidas Frescas ou Secas

$85 \%$

Verificou-se que o processo de secagem é aplicado de acordo com a parte extraída da planta. As plantas que são vendidas frescas são principalmente as fornecedoras de sementes, frutos e exsudatos (óleos, resinas e látex), enquanto as vendidas secas são fornecedoras de cascas, raízes, planta toda, folhas e ramos, conforme mostra a tabela 18 .

Tabela 18 - Partes vegetais comercializadas verdes e secas com suas freqüências de citações, segundo a amostra dos extratores e produtores de plantas medicinais da região do Vale do Ribeira, SP. 


\begin{tabular}{l|c|l|c}
\hline \multicolumn{1}{c|}{$\begin{array}{c}\text { Partes vegetais } \\
\text { comercializadas verdes }\end{array}$} & Citações & $\begin{array}{c}\text { Partes vegetais } \\
\text { comercializadas secas }\end{array}$ & Citações \\
\hline Folha & 2 & Folha & 154 \\
\hline Planta toda & 1 & Planta toda & 105 \\
\hline Parte aérea & 2 & Parte aérea & 89 \\
\hline Ramo & 0 & Ramo & 57 \\
\hline Raiz & 0 & Raiz & 48 \\
\hline Casca do caule & 5 & Casca do caule & 40 \\
\hline Cipó & 0 & Cipó & 23 \\
\hline Lenho & 11 & Lenho & 11 \\
\hline Outras partes & 3 & Outras partes & 7 \\
\hline Semente & 8 & Semente & 7 \\
\hline Resina & 5 & Resina & 7 \\
\hline Flor & 0 & Flor & 4 \\
\hline Fruto & 4 & Fruto & 4 \\
\hline Caule & 0 & Caule & 1 \\
\hline Óleo & 1 & Óleo & 0 \\
\hline Látex & 1 & Látex & 0 \\
\hline
\end{tabular}

O material vegetal extraído, antes de passar pelo processo de secagem, quase sempre, passa por um processo de limpeza denominado triagem pelos entrevistados. Esse processo é mais raro para o material vendido fresco. Verificou-se que a parte extraída da planta determina a escolha de uma ou mais das três formas de triagem, listadas a seguir com os respectivos procedimentos:

1. Retirada de contaminantes: os contaminantes podem ser animais ou partes deles, como por exemplo aranhas, percevejos e ovos de moscas, poeira, terra (restos do solo) e fragmentos de outros vegetais, como musgos, liquens e fungos;

2. Lavagem da parte vegetal extraída: lavagem da parte extraída para retirar contaminantes, como restos de solo;

3. Descarte de parte do órgão vegetal extraído: como por exemplo a "ponteira" (extremidade) dos ramos. Segundo os entrevistados, se a "ponteira" não for retirada, os ramos podem mudar bruscamente de coloração ou aroma após a secagem.

Conforme mencionado anteriormente, mais de uma forma de triagem pode ser usada para uma mesma parte extraída da planta. Portanto, para as 244 fichas de beneficiamento citadas, os entrevistados citaram 250 formas de triagem empregadas 
para as 130 plantas comercializadas secas. As principais formas de triagem correlacionadas com as partes extraídas, comercializadas secas, bem como suas respectivas freqüências, estão apresentadas na tabela 19. Verifica-se que as principais formas de triagem, correlacionadas com a parte extraída da planta, são: raspagem de musgos, liquens e fungos, para casca do caule; retirada de bichos e sujeiras, para folhas, ramos e parte aérea; lavagem, para raízes e rizomas; lavagem da raiz e retirada de contaminantes, para a planta toda.

Tabela 19 - Partes vegetais comercializadas secas com o número de citações para a forma de triagem usada pela amostra dos extratores e produtores de plantas medicinais da região do Vale do Ribeira, SP.

\begin{tabular}{l|l|c}
\hline \multicolumn{1}{c|}{ Parte extraída } & \multicolumn{1}{|c}{ Forma de triagem } & Citações \\
\hline Casca do caule & Raspagem de musgos, liquens e fungos da casca & 22 \\
\hline Casca do caule & Retirada de sujeira & 1 \\
\hline Casca do caule & Sem informação & 1 \\
\hline Caule & Raspagem de musgos, liquens e fungos da casca & 1 \\
\hline Cipó & Sem informação & 2 \\
\hline Cipó & Raspagem de musgos, liquens e fungos da casca & 1 \\
\hline Cipó & Retirada de bichos & 1 \\
\hline Cipó & Retirada de sujeira & 1 \\
\hline Flor & Retirada de bichos & 2 \\
\hline Flor & Retirada de sujeira & 2 \\
\hline Folha & Retirada de bichos & 27 \\
\hline Folha & Retirada de sujeira & 22 \\
\hline Folha & Retirada de folhas secas e ruins & 11 \\
\hline Folha & Lavagem de planta & 1 \\
\hline Folha & Sem informação & 7 \\
\hline Folha & Outros & 4 \\
\hline Folha & Despreza-se a ponta porque fica escura na secagem & 1 \\
\hline Fruto & Sem informação & 2 \\
\hline Lenho & Raspagem de musgos, liquens e fungos da casca & 1 \\
\hline Lenho & Retirada de bichos & 1 \\
\hline Lenho & Retirada de sujeira & \multicolumn{1}{|c}{} \\
\hline & Sem informação & 1 \\
\hline
\end{tabular}




\begin{tabular}{l|l|c}
\hline \multicolumn{1}{c|}{ Parte extraída } & \multicolumn{1}{|c}{ Forma de triagem } & Citações \\
\hline Outros & Retirada de folhas secas e ruins & 1 \\
\hline Outros & Lavagem da raiz & 1 \\
\hline Parte aérea & Retirada de bichos & 9 \\
\hline Parte aérea & Retirada de sujeira & 9 \\
\hline Parte aérea & Sem informação & 7 \\
\hline Parte aérea & Retirada de folhas secas e ruins & 3 \\
\hline Parte aérea & Outros & 3 \\
\hline Planta toda & Lavagem da raiz & 16 \\
\hline Planta toda & Retirada de sujeira & 15 \\
\hline Planta toda & Retirada de bichos & 13 \\
\hline Planta toda & Sem informação & 9 \\
\hline Planta toda & Lavagem de planta & 3 \\
\hline Planta toda & Retirada de folhas secas e ruins & 1 \\
\hline Raiz & Lavagem da raiz & 26 \\
\hline Raiz & Sem informação & 3 \\
\hline Ramo & Sem informação & 8 \\
\hline Ramo & Retirada de bichos & 3 \\
\hline Ramo & Retirada de sujeira & 2 \\
\hline Ramo & Despreza-se a ponta porque fica escura na secagem & 1 \\
\hline Semente & Sem informação & 2 \\
\hline
\end{tabular}

O material vegetal pode passar por um processo de fragmentação ou de "maceração" antes de sua secagem. O primeiro caso é usado para raízes e cascas, e o segundo, é empregado para materiais suculentos, objetivando a liberação da água.

Quanto à secagem do material vegetal, os entrevistados podem realizá-la sob o sol ou à sombra ou, ainda, com o uso de fornos de secagem. Quando secas ao natural, as plantas podem ser espalhadas diretamente no chão (foto 5) ou sobre esteiras ou bandejas (foto 6). Quando secas nos fornos, sua disposição depende do tipo de forno usado. 


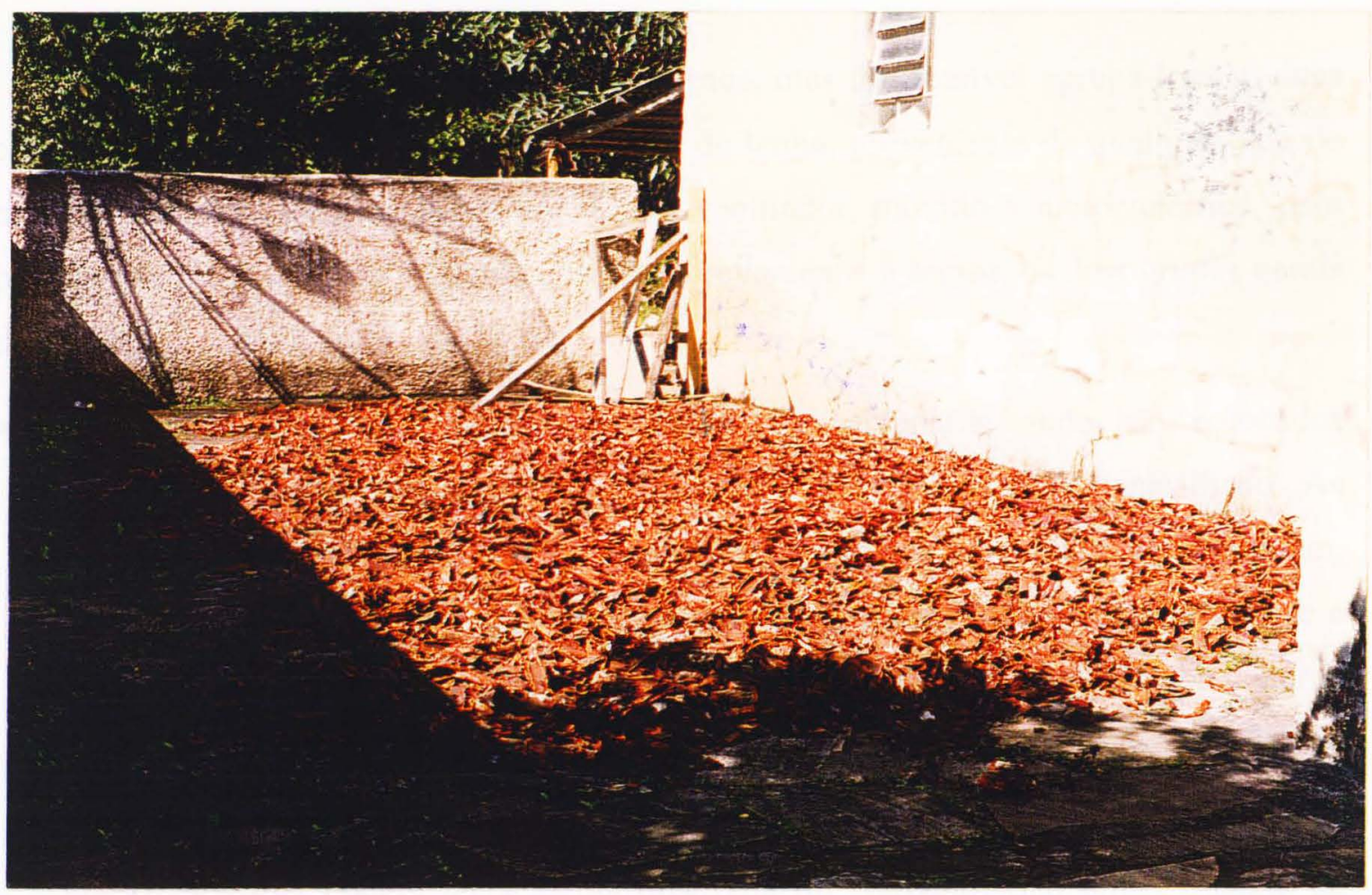

Foto 5. Material vegetal secando ao sol, no chão.

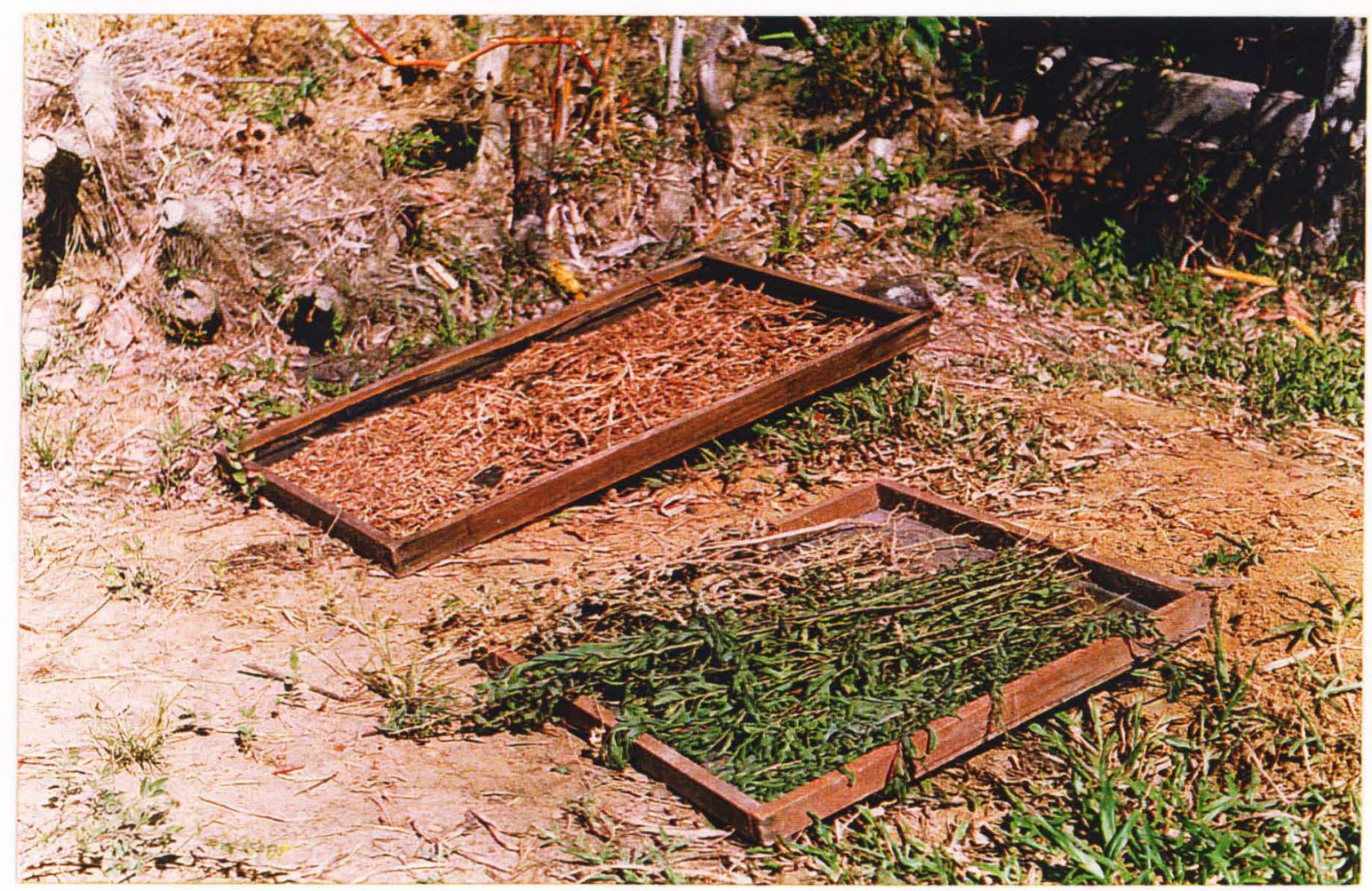

Foto 6. Material vegetal secando ao sol, em bandejas. 
Foram encontrados vários tipos de fornos, mas foi possivel agrupá-los em duas categorias. Ambos são aquecidos com o uso de lenha, proveniente de qualquer tipo de madeira disponível e abundante, e possuem ventilador, movido a motor elétrico, para promover a circulação do ar. Serão descritos brevemente, a seguir, os dois grupos gerais de fornos:

- Fornos fechados: são câmaras, geralmente de alvenaria, onde são colocados "carrinhos" com prateleiras gradeadas onde o material vegetal é espalhado. As prateleiras gradeadas facilitam a circulação do ar aquecido e aumentam, conseqüentemente, a eficiência da secagem. No interior da câmara, o ar quente é canalizado para todas as partes do forno, que é aquecido por fornalha externa alimentada a lenha, e seu movimento se dá por sistema de ventilação. A temperatura média é em torno de $60^{\circ} \mathrm{C}$ (fotos 7,8 e 9).

- Fornos abertos: podem ter a forma quadrada ou circular. São uma "espécie de tambor" de metal ou de alvenaria com duas câmaras, uma fechada e outra aberta em sua parte superior, onde se processa a secagem do material vegetal por contato com a superfície aquecida. Na câmara fechada circula o ar aquecido pela queima de lenha em uma fornalha localizada no lado inferior do forno. A circulação do ar quente é por ventilação que entra e circula no interior do "tambor", aquecendo a superfície. Neste tipo de forno, a temperatura não é controlada, por isso, o material vegetal deve ser constantemente revolvido para que não queime. Isso pode ser realizado por uma pessoa dentro do forno, calçado com botas de borracha, em cima do material vegetal que está secando, e com o auxilio de uma pá. 


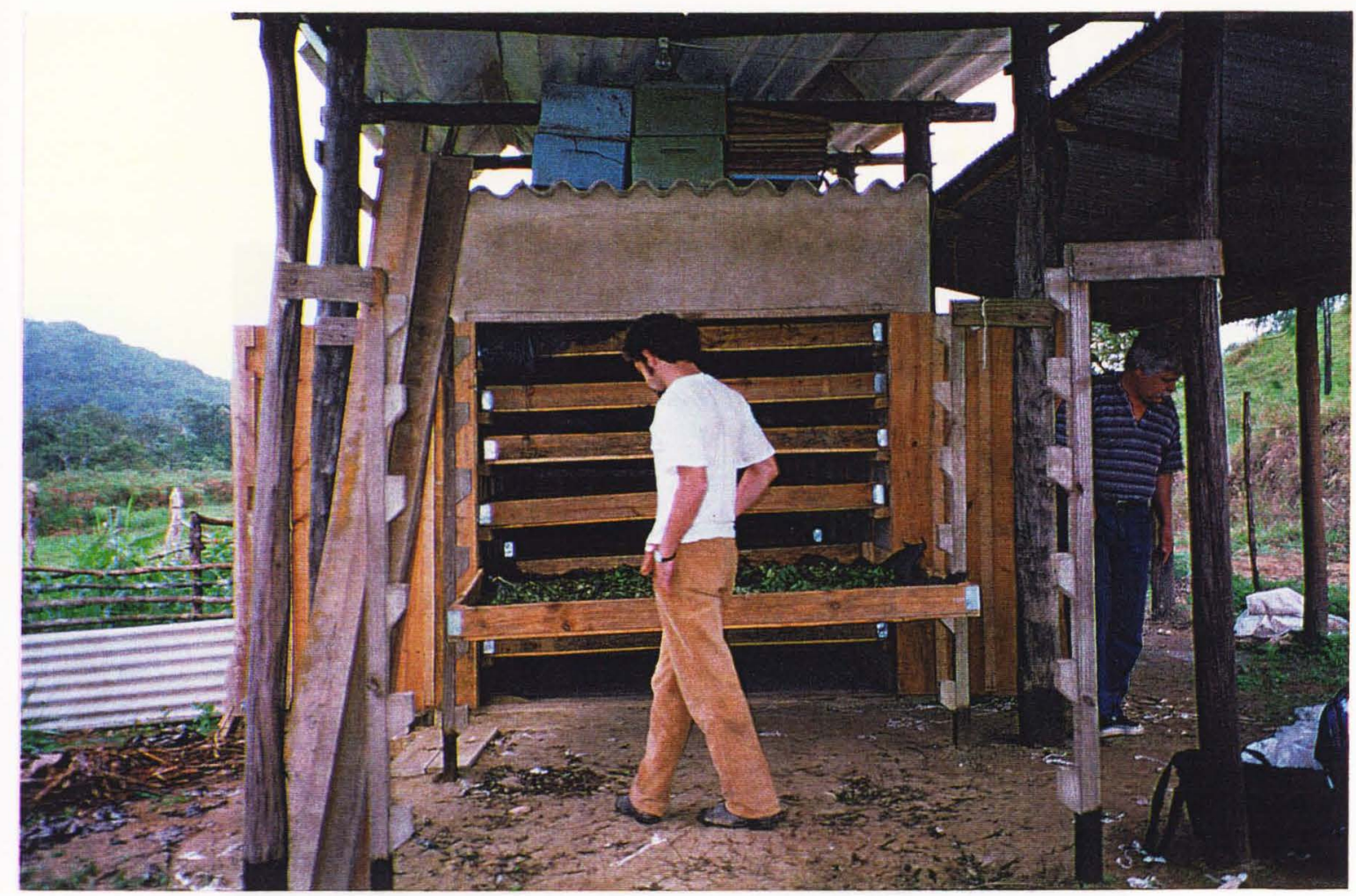

Foto 7. Forno fechado de manuseio externo.

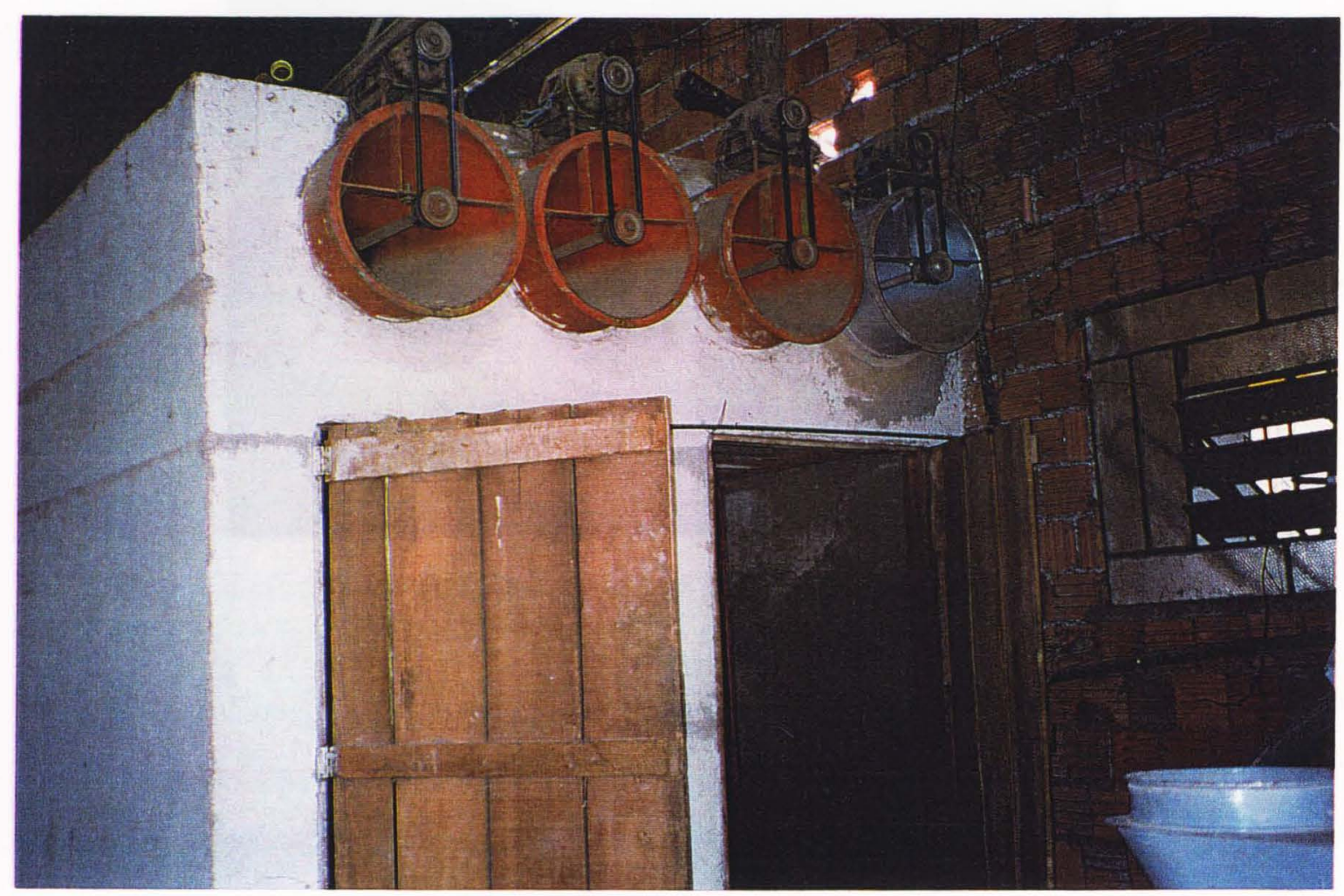

Foto 8. Sistema de ventilação do forno fechado. 


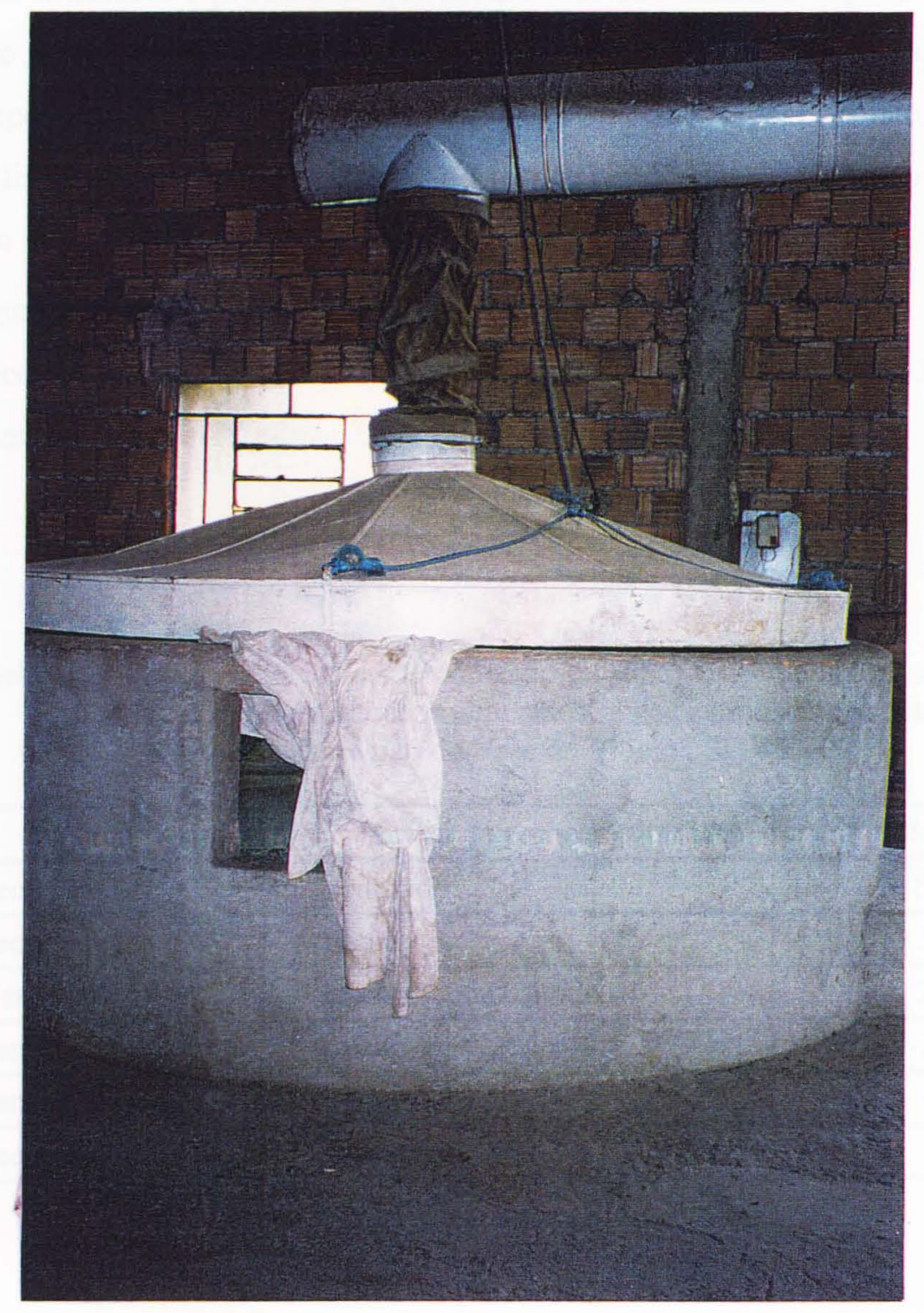

Foto 9. Forno fechado redondo. 
Não há indicação específica, por planta, do tipo de secagem a ser procedida, visto que há extratores e produtores que secam todo seu material vegetal ao natural e há aqueles que o secam em forno. O tempo de secagem do material depende da época do ano e do tipo do material. Durante a estação seca pode-se secar ao natural ou usar os dois procedimentos; ao natural e depois ao forno. $\mathrm{Na}$ época de chuva, os entrevistados informaram que também utilizam o forno.

Segundo as informações fornecidas pelos entrevistados, há maior tendência de o material seco ser vendido triturado (fragmentado). Os materiais frescos são, geralmente, comercializados inteiros. A tabela 20 demonstra essas correlações.

Tabela 20 - Tipo de material comercializado e formas de comercialização mais comuns para as plantas citadas pela amostra dos extratores e produtores de plantas medicinais da região do Vale do Ribeira, SP.

\begin{tabular}{l|l|c}
\hline \multicolumn{1}{c|}{ Tipo de material } & Forma de comercialização & Citações \\
\hline Seco & Triturado & 158 \\
\hline Seco & Inteiro & 38 \\
\hline Verde & Inteiro (como obtido) & 22 \\
\hline Sem informação & Triturado & 17 \\
\hline Sem informação & Sem informação & 4 \\
\hline Seco & Sem informação & 5 \\
\hline
\end{tabular}

O tamanho dos fragmentos do material triturado depende do entrevistado. Um dos guias principais tem como padrão geral de fragmentação de seu material o chamado "sachê" que consiste em fragmentar o material em pedaços com cerca de $1 \mathrm{~cm}$. Outros entrevistados usam também esse padrão ou fragmentam o material vegetal seco em pedaços de cerca de $2 \mathrm{~cm}$ ou de $10 \mathrm{~cm}$. Há extratores e produtores que vendem seu material vegetal em forma de pó. A foto 10 mostra uma máquina de trituração. A tabela 21 apresenta os padrões de fragmentação e suas respectivas citações. 


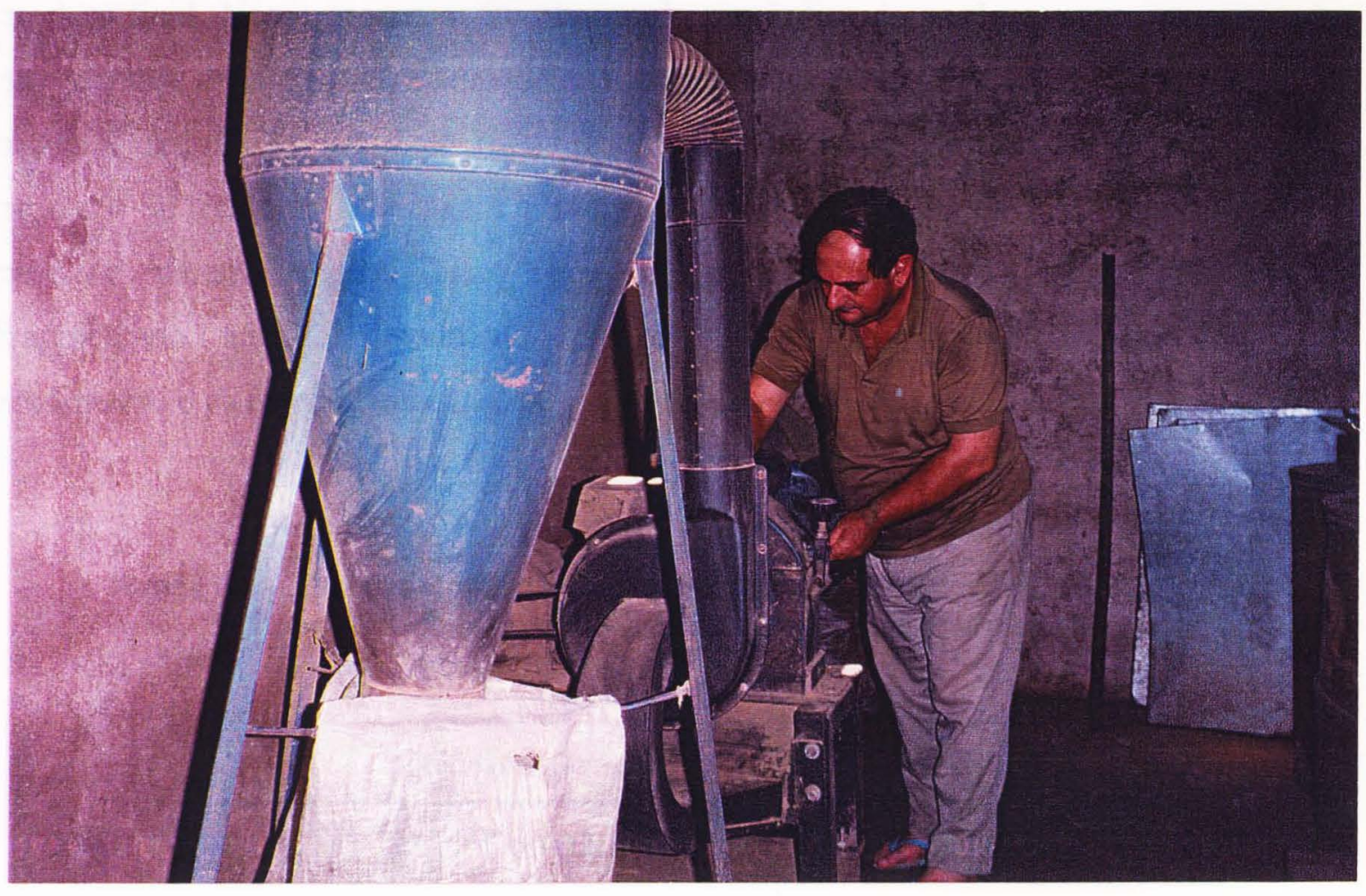

Foto 10. Máquina de trituração de plantas medicinais.

Tabela 21 - Padrões de fragmentação e suas respectivas citações, segundo a amostra dos extratores e produtores de plantas medicinais da região do Vale do Ribeira, SP..

\begin{tabular}{l|c}
\hline \multicolumn{1}{c|}{ Graus de fragmentação } & Citações \\
\hline \hline Sachê de $1 \mathrm{~cm}$ para chá & 153 \\
\hline Sem informação & 19 \\
\hline Pedaços de $2 \mathrm{~cm}$ & 6 \\
\hline Outros tamanhos & 6 \\
\hline Pedaços de $10 \mathrm{~cm}$ & 12 \\
\hline
\end{tabular}


Foram obtidas também informações sobre as faixas de rendimento do material extraído. Para isso, os entrevistados informaram a relação entre o peso fresco do material extraído da planta e o peso seco do material triturado, ou seja, o peso do produto final. Nesse processo, foi observado um índice de perda em peso apresentado nas plantas, considerando-se também as perdas que ocorrem durante o transporte do material extraído (a partir do local de extração até a estação de beneficiamento), no processo de triagem, na secagem e na trituração. Procurou-se verificar a quantidade do peso do material vegetal fresco necessária para se obter $1 \mathrm{~kg}$ de produto seco e fragmentado. Isso foi determinado em faixas. A tabela 22 apresenta as faixas de rendimento e as respectivas citações.

Tabela 22 - Faixas de rendimento das plantas e suas respectivas citações, segundo a amostra dos extratores e produtores de plantas medicinais da região do Vale do Ribeira, SP.

\begin{tabular}{c|c}
\hline Rendimento & Citações \\
\hline Sem informação & 68 \\
\hline$>10 / 1$ & 68 \\
\hline $2 / 1 \bullet----4 / 1$ & 48 \\
\hline $6 / 1 \bullet----8 / 1$ & 21 \\
\hline$<2 / 1$ & 16 \\
\hline $4 / 1 \bullet-\cdots-6 / 1$ & 13 \\
\hline $8 / 1 \bullet----10 / 1$ & 10 \\
\hline
\end{tabular}

Os entrevistados utilizam alguns critérios para controlar a qualidade do material seco a ser comercializado. Dentre eles, os principais critérios são os seguintes:

- Coloração final do material;

- Grau de secagem e consistência que o material adquire; 
- Permanência de aroma nos materiais aromáticos;

- Grau de fragmentação do material de acordo com o padrão predeterminado.

Para realizar o controle de qualidade do material seco, os entrevistados utilizam mais de um critério para cada material vegetal a ser comercializado. Eles forneceram um total de 258 citações de emprego dos 4 critérios de controle de qualidade para as 201 citações de material comercializado seco (ver tabela 20). Na tabela 23, são apresentados esses critérios, assim como a relação existente entre a parte extraída e a utilização dos critérios de controle de qualidade. Nessa tabela:

- para casca do caule e raízes, observa-se principalmente a consistência e o grau de secagem;

- para folha (a parte vegetal com maior número de citações para controle de qualidade), observa-se a coloração, ou seja, a permanência de pigmentos (especialmente clorofila), seguida pela consistência e pelo grau de secagem;

- para parte aérea e planta toda, a coloração constitui também principal parâmetro de controle de qualidade.

Tabela 23 - Relação entre as partes extraídas e os critérios utilizados para o controle de qualidade das plantas citadas pela amostra dos extratores e produtores de plantas medicinais da região do Vale do Ribeira, SP.

\begin{tabular}{l|l|c}
\hline \multicolumn{1}{c|}{ Parte da planta } & \multicolumn{1}{c|}{ Aspecto considerado } & Citações \\
\hline Casca do caule & Consistência & 7 \\
\hline Casca do caule & Grau de secagem & 7 \\
\hline Casca do caule & Coloração & 6 \\
\hline Casca do caule & Sem informação & 5 \\
\hline Caule & Sem informação & 1 \\
\hline Cipó & Grau de secagem & 3 \\
\hline Cipó & Sem informação & 2 \\
\hline Cipó & Coloração & 1 \\
\hline Flor & Presença de aroma & 2 \\
\hline Flor & Coloração & 2 \\
\hline Flor & Grau de secagem & 2 \\
\hline Folha & Coloração & 37 \\
\hline
\end{tabular}




\begin{tabular}{|c|c|c|}
\hline Parte da planta & Aspecto considerado & Citações \\
\hline Folha & Grau de secagem & 19 \\
\hline Folha & Consistência & 18 \\
\hline Folha & Sem informação & 5 \\
\hline Folha & Outros & 1 \\
\hline Folha & Presença de aroma & 1 \\
\hline Fruto & Sem informação & 2 \\
\hline Lenho & Grau de secagem & 2 \\
\hline Lenho & Sem informação & 1 \\
\hline Lenho & Coloração & 1 \\
\hline Lenho & Consistência & 1 \\
\hline Outros & Consistência & 1 \\
\hline Outros & Grau de secagem & 1 \\
\hline Outros & Coloração & 1 \\
\hline Parte aérea & Coloração & 12 \\
\hline Parte aérea & Sem informação & 7 \\
\hline Parte aérea & Grau de secagem & 5 \\
\hline Parte aérea & Consistência & 4 \\
\hline Planta toda & Coloração & 18 \\
\hline Planta toda & Sem informação & 12 \\
\hline Planta toda & Consistência & 8 \\
\hline Planta toda & Grau de secagem & 8 \\
\hline Raiz & Grau de secagem & 12 \\
\hline Raiz & Consistência & 12 \\
\hline Raiz & Sem informação & 6 \\
\hline Raiz & Coloração & 6 \\
\hline Raiz & Presença de aroma & 1 \\
\hline Ramo & Sem informação & 8 \\
\hline Ramo & Coloração & 3 \\
\hline Ramo & Consistência & 2 \\
\hline Ramo & Grau de secagem & 2 \\
\hline Ramo & Outros & 1 \\
\hline Semente & Sem informação & 2 \\
\hline
\end{tabular}

Um dos guias principais submete seu material vegetal que será comercializado a um rigoroso conjunto de critérios de controle de qualidade e assepsia. Ele faz a triagem de seu material por coloração, grau de aromatização, grau de desidratação, parte pedida 
da planta e fragmentação adequada. Seu manuseio é cuidadosamente limpo, bem como suas instalações na estação de beneficiamento. O prazo de validade máximo de seu material é de um ano e ele ressalta ainda que não faz estoque porque com o tempo o material perde a qualidade. A foto 11 mostra as diferentes colorações dos materiais, critério muito considerado para o controle de qualidade.

Em relação à armazenagem, os entrevistados afirmaram não armazenar nenhum tipo de material. Entretanto, contrariando tal afirmativa, foi possível observar materiais secos em pedaços maiores e até ramos, em tambores (foto 12) ou em sacos plásticos de tamanhos variados, empilhados em grandes quantidades.

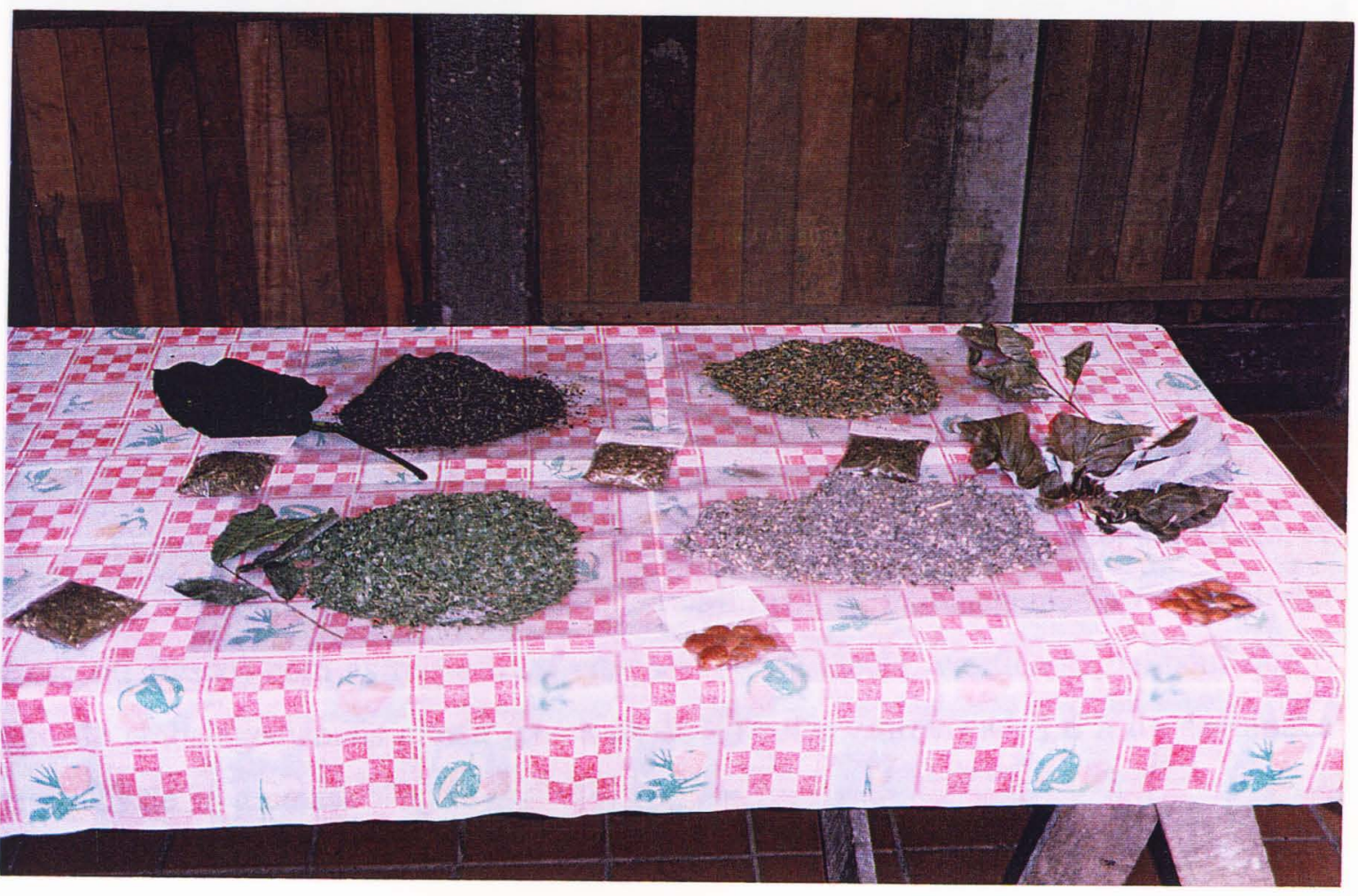

Foto 11. Material seco e fragmentando, apresentando diferentes colorações de acordo com a planta correspondente. Este é um dos critérios usados pelos entrevistados para controlar a qualidade do produto final. 


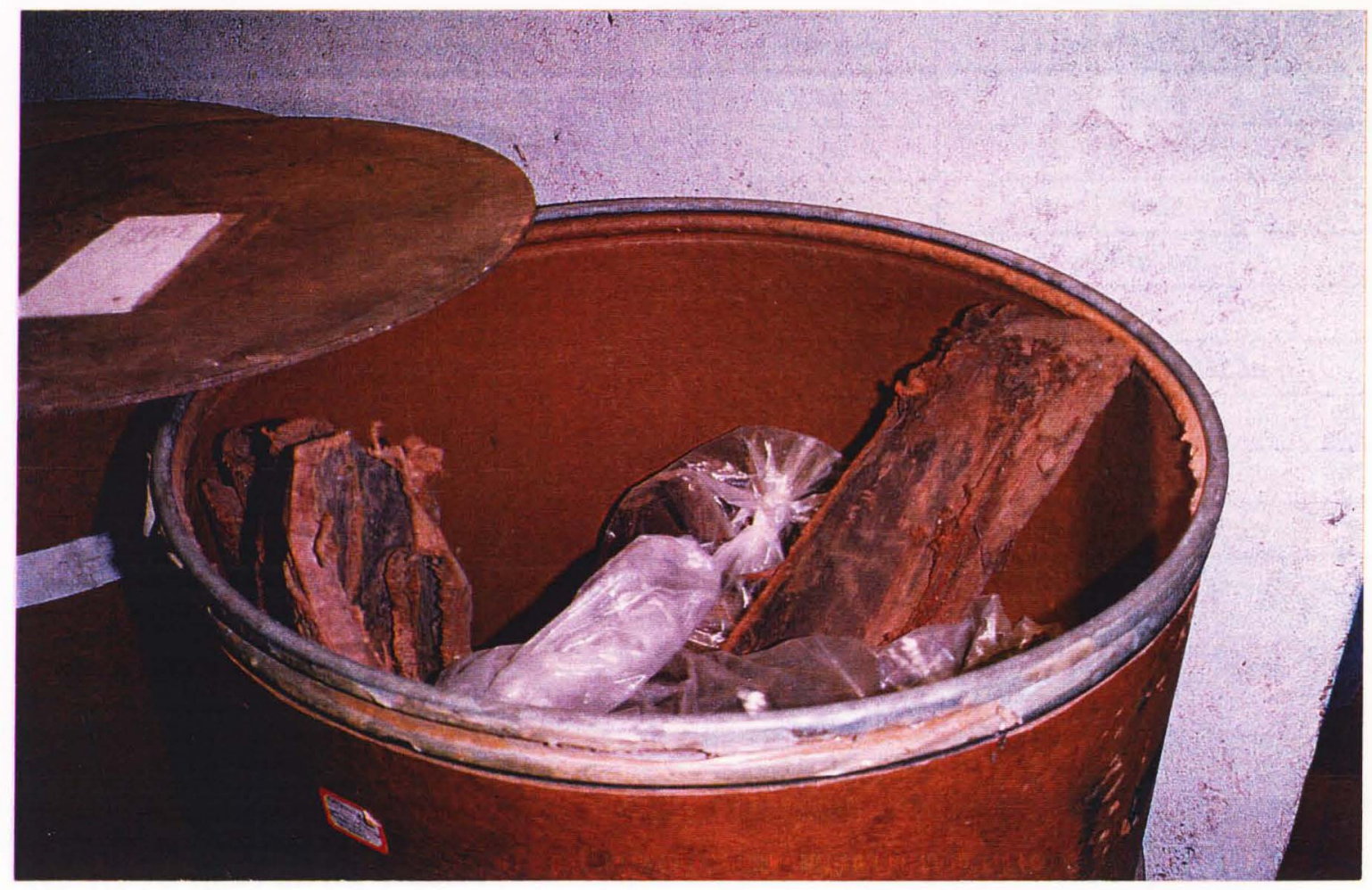

Foto 12. Material vegetal armazenado em tambores hermeticamente fechados.

O material vegetal, seco ou não, é comercializado, principalmente, embalado. A tabela 24 apresenta a correlação existente entre tipos de embalagem, tipo do material ( tipo de embalagem mais citada (cerca de 55\%) pelos entrevistados é a de saquinhos plásticos de 30 gramas. 
Tabela 24 - Tipos de embalagens utilizados para a venda do material comercializado seco ou fresco (plantas citadas) pela amostra dos extratores e produtores de plantas medicinais da região do Vale do Ribeira, SP.

\begin{tabular}{l|c|c}
\hline \multicolumn{1}{c|}{ Embalagem } & Citações & Tipo de Material \\
\hline Saquinhos plásticos de 30 gramas & 134 & Seco \\
\hline Saquinhos plásticos de 30 gramas & 10 & Fresco \\
\hline A granel - sacos de 60 quilos & 71 & Seco \\
\hline Outras embalagens & 12 & Fresco \\
\hline Sem informação & 5 & Seco \\
\hline Sem informação & 4 & Sem informação \\
\hline Sacos de 1 quilo & 3 & Seco \\
\hline Outras embalagens & 4 & Seco \\
\hline A granel - sacos de 60 quilos & 1 & Sem informação
\end{tabular}

As faixas de preço de um quilograma de material vegetal variaram de menos de $\mathrm{R} \$ 1,00$ a mais de $\mathrm{R} \$ 20,00^{3}$. A discrepância nos valores foi justificada pela qualidade do material vendido. Os extratores e produtores entrevistados vendem, em média, um quilo de material seco e fragmentado por valores em torno de $\mathrm{R} \$ 1,00$ a $\mathrm{R} \$ 3,00$ e seus compradores são em geral atacadistas.

Um dos guias principais vende seus produtos de qualquer tipo de planta por um único preço, ou seja, $\mathrm{R} \$ 0,85$ o saquinho de 30 gramas, ou $\mathrm{R} \$ 15,00$ o quilo. Seus principais compradores são laboratórios. Não há diferença de preço por planta, mesmo que haja diferença de rendimento ou de trabalho dèspendido para sua obtenção ou beneficiamento, pois seu lucro é dado pela média: "O preço de todas as plantas é o mesmo, um compensa o outro".

O gráfico 14 e a tabela 25 mostram que os laboratórios e as lojas de produtos naturais pagam preços mais altos pelo quilograma de material vegetal. Cerca de $91 \%$ de

${ }^{3}$ Câmbio considerado: R\$1,11 = US\$1,00. 
todos os compradores que chegam a pagar de $\mathrm{R} \$ 20,00$ o quilograma de material vegetal são compostos pelos laboratórios e pelas lojas de produtos naturais. Esses compradores são os mais exigentes quanto à qualidade do material.

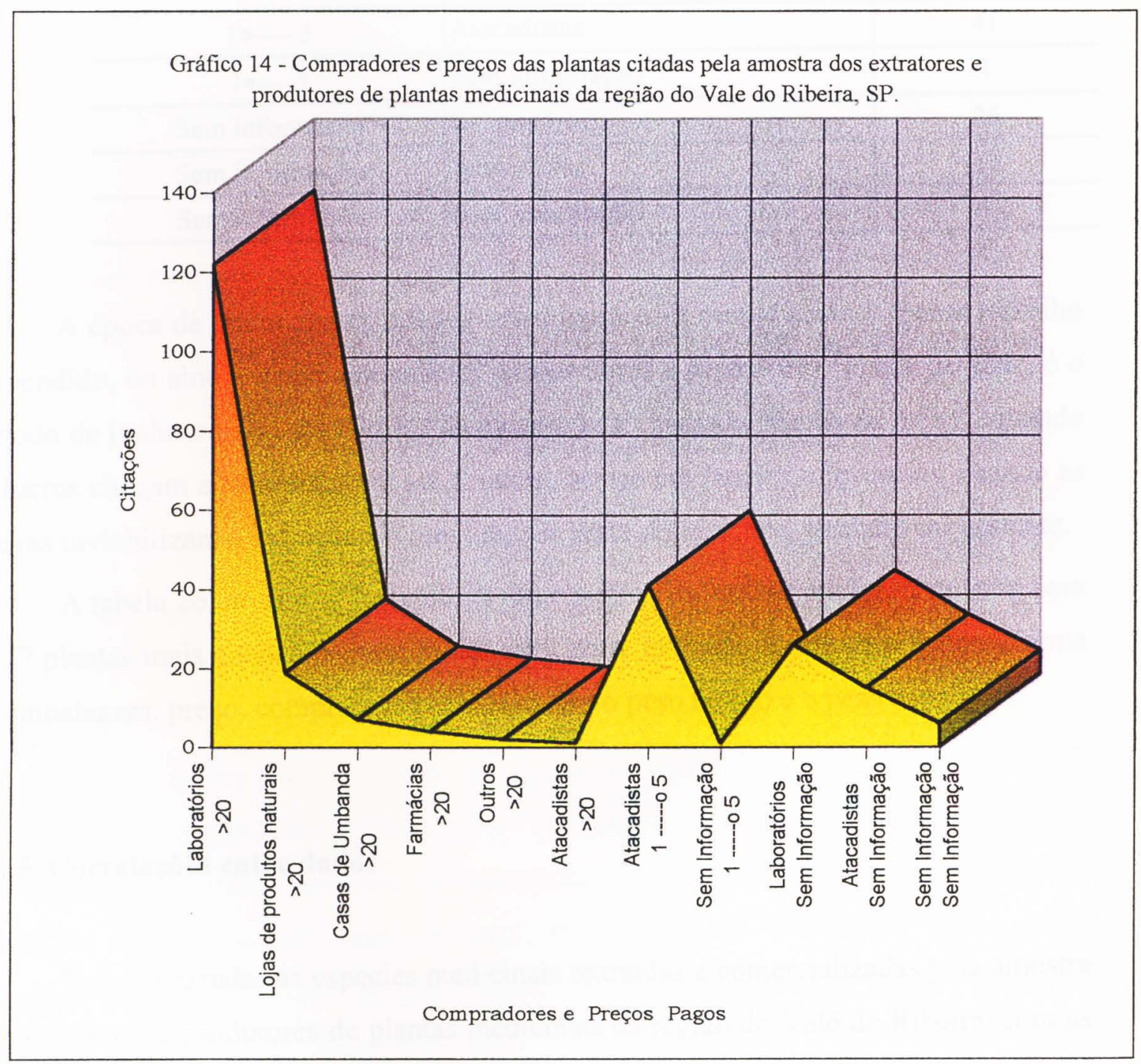


Tabela 25 - Faixa de preço em reais por quilo de material comercializado, os compradores e as respectivas citações, segundo a amostra dos extratores $\mathrm{e}$ produtores de plantas medicinais da região do Vale do Ribeira, SP.

\begin{tabular}{c|l|c}
\hline Faixas de preços (RS) & \multicolumn{1}{c|}{ Compradores } & Citações \\
\hline$>20$ & Laboratórios & 122 \\
\hline$>20$ & Lojas de produtos naturais & 19 \\
\hline$>20$ & Casas de umbanda & 7 \\
\hline$>20$ & Farmácias & 4 \\
\hline$>20$ & Outros & 2 \\
\hline$>20$ & Atacadistas & 1 \\
\hline $1 \bullet---5$ & Atacadistas & 41 \\
\hline $1 \bullet---5$ & Sem informação & 1 \\
\hline Sem informação & Laboratórios & 26 \\
\hline Sem informação & Atacadistas & 15 \\
\hline Sem informação & Sem informação & 6 \\
\hline
\end{tabular}

A época de maior rentabilidade, maior lucro com menor custo e menor trabalho despendido, ou ainda, como denominam os extratores e produtores "época de alta", é o período de junho e julho até meados de agosto; já a chamada "época de baixa", quando os lucros chegam a se reduzir em até 5 vezes, ocorre em janeiro e fevereiro, quando as chuvas inviabilizam a extração e a procura, por parte do mercado, também cai bastante.

A tabela 26, no anexo 4, apresenta um resumo dos temas tratados neste item para as 27 plantas mais citadas pelos entrevistados: parte extraída, forma de secagem, forma de embalagem, preço, compradores, relação entre o peso úmido e o peso seco.

\subsubsection{Correlações entre dados}

Foram cruzadas as espécies medicinais extraídas e comercializadas pela amostra dos extratores e produtores de plantas medicinais da região do Vale do Ribeira, com as espécies listadas nos trabalhos de BORN (1999) e de SCHEFFER (1995) (ver item 3.3.2. Aspectos do mercado de plantas medicinais). As espécies medicinas citadas pelos entrevistados foram cruzadas também com as espécies usadas como remédio pelas comunidades tradicionais da Estação Ecológica de Juréia-Itatins (dados inéditos de 
Gemima C. Cabral Born; ver 2.1. - O Vitae Civilis ).

Os objetivos desses cruzamentos foram verificar se os entrevistados estavam explorando o potencial do mercado da região metropolitana de São Paulo e do mercado de exportação, assim como o potencial da diversidade de plantas medicinais conhecidas e usadas por comunidades tradicionais que vivem na região do Vale do Ribeira.

Foram encontrados os seguintes resultados:

- 123 espécies foram encontradas entre as 731 espécies comercializadas no mercado da região metropolitana de São Paulo (BORN, 1999);

- 93 espécies foram encontradas entre as 325 possiveis espécies exportadas no Aeroporto Internacional de Guarulhos, no período de março a dezembro de 1994 (SCHEFFER, 1995);

- 56 espécies foram encontradas entre as 373 espécies usadas como remédio pelas comunidades tradicionais da Juréia-Itatins (trabalho inédito de Gemima C. Cabral Born).

Esses dados indicam que há um potencial de mercado e de diversidade de espécies da Mata Atlântica maior que a explorada e comercializada pela amostra dos extratores e produtores de plantas medicinais da região do Vale do Ribeira. O potencial do mercado, tanto o nacional como o internacional, também não é explorado pelos entrevistados. Isso significa que provavelmente os entrevistados poderão realizar um dos seus desejos que é alcançar o mercado internacional, conforme pode ser verificado em depoimentos apresentados anteriormente. Esses dados demonstram também que as comunidades tradicionais da região, como as da Juréia-Itatins, conhecem mais a diversidade e o uso das plantas que o próprio mercado que comercializa plantas que não são estudadas no meio científico. Se se compararem esses dados com os dos estudos científicos realizados com essas espécies, seria verificado claramente que o meio científico desconhece muito da diversidade genética, biológica e cultural da Mata Atlântica. Isso corrobora com vários estudiosos que se referem à ignorância do meio científico brasileiro e, também, internacional, no que se refere à riqueza dos trópicos. 


\section{DESAFIOS PARA O USO SUSTENTÁVEL DE PLANTAS MEDICINAIS}

$\mathrm{Na}$ entrada do terceiro milênio, há um desejo que predomina em quase todas as pessoas: ter um mundo melhor, onde haja eqüidade social e misericórdia entre as pessoas, a fé seja materializada e as perdas sejam divididas. Esse desejo para muitos é um sonho, uma utopia, por causa da violência em vários países do mundo, dentre os quais se destaca o Brasil. Há um desconforto generalizado entre os brasileiros, principalmente entre aqueles que vivem em grandes cidades, como São Paulo, por causa do alto nível de violência encontrado em qualquer lugar e a qualquer momento.

Passando esse desejo para o conceito moderno, discutido no decorrer desta tese, ou seja, o do desenvolvimento sustentável como um meio para se conseguir sociedades sustentáveis, verifica-se que, infelizmente, o processo de desenvolvimento sustentável é incipiente, complexo e difícil. Mas há evidências, mesmo que acanhadas considerando a grandeza da questão, de que há tentativas para alavancar esse processo. Por causa das dificuldades encontradas para ampliar esse processo de forma significativa é freqüente a descrença de muitos na possibilidade de chegarmos a ter sociedades sustentáveis. Conforme foi visto anteriormente, isso é um sonho, um desejo, uma utopia, mas o ser humano vive de sonhos, utopias e desejos. Essa utopia de iniciar o processo de desenvolvimento sustentável, precisa ser conquistada gradativamente, em períodos curtos, para que a geração atual possa visualizar, sentir, entender e acreditar no processo. Todos da sociedade civil têm compromisso com esse processo, mas lideranças, autoridades, técnicos do governo, empresários e cientistas, por serem formadores de opinião, têm destacada responsabilidade nele.

Para isso chegar a ocorrer é necessário que os princípios de "sociedade sustentável", de acordo com o conceito publicado no relatório Cuidando do planeta terra: uma estratégia para o futuro da vida (IUCN, PNUMA, WWF, 1992), sejam seguidos:

1. Respeitar e cuidar da comunidade dos seres vivos.

2. Melhorar a qualidade da vida humana.

3. Conservar a vitalidade e a diversidade do planeta Terra. 
4. Minimizar o esgotamento de recursos não-renováveis.

5. Permanecer nos limites da capacidade de suporte do planeta Terra.

6. Modificar atitudes e práticas pessoais.

7. Permitir que as comunidades cuidem de seu próprio meio ambiente.

8. Gerar uma estrutura nacional para a integração de desenvolvimento e conservação.

9. Constituir uma aliança global.

Analisando esses princípios sob o prisma de que dependem de um conjunto de sustentabilidades parciais e do contexto do uso da exploração e comercialização de plantas medicinais da Mata Atlântica como um dos instrumentos da busca desse tipo de desenvolvimento da região do Vale do Ribeira, verifica-se que a população e os atores sociais dessa região, assim como as outras populações brasileiras, precisam internalizar novos hábitos, modificar atitudes e práticas pessoais e coletivas.

Essas mudanças passam pelo processo de elevar a auto-estima da população local, seja valorizando as riquezas culturais, biológicas e genéticas, assim como valorizando o contexto cênico encontrado na região, seja exigindo respeito por parte de instituições e indivíduos que têm poder de interferir nos modos de vida da população local. Ambos os casos são vistos nos respectivos depoimentos reapresentados a seguir:

"Eu fiquei muito chateado porque nunca tive multa. Tenho vergonha. Não consigo nem trabalhar direito. Se eu tivesse esse dinheiro eu pagaria, mas não tenho nada." (Sr. G) (O morador da Juréia-Itatins se referia à multa recebida da Polícia Florestal por ter feito sua roça usando técnicas da agricultura itinerante e também por ter sido denunciado por guardas-parque, antes amigos e parentes.).

"Todos os que vêm aqui dizem que a Mata Atlântica é rica e que nós poderíamos usar essa riqueza. Mas eles vão embora e nós continuamos vivendo do mesmo jeito, sem condições de vida boa." (Sra. H) 
Há várias estratégias para elevar a auto-estima. Serão enfatizadas duas delas: o equilibrio do individuo e o da coletividade. $\mathrm{O}$ equilíbrio do indivíduo significa maior e melhor autoconhecimento, com clareza e coerência entre o que se fala e o que se faz. Isso não significa rigidez. Ao contrário, isso significa maior leveza e integração entre a mente e o corpo. Isso é análogo à dança do ventre, pois a bailarina tem de integrar sua mente com a parte do corpo que dança para conseguir dançar perfeitamente. $O$ equilibrio individual é muito importante para se atingir o equilíbrio coletivo.

Para as mudanças coletivas uma das estratégias promissoras é a formação de grupos que procurem deixar claro quem são, como vivem, como gostariam de viver e quais são as estratégias e as ações do grupo e dos atores externos. Uma das estratégias para trabalhar essas questões, assim como para documentá-las, é a elaboração de uma Agenda 21 comunitária. Um exemplo disso, envolvendo uma comunidade rural da Mata Atlântica é a Agenda 21 do Bairro do Guapiruvu, conforme apresentado no item 3.1 Sustentabilidade do desenvolvimento.

A integração e a articulação das ações são fundamentais na busca da sustentabilidade do desenvolvimento. Isso deve ocorrer também no âmbito de todos os segmentos da sociedade, especialmente entre os órgãos $e$ as instituições que desempenham funções semelhantes em uma mesma área, como a do Vale do Ribeira. Por exemplo, para que o DEPRN e o Ibama sejam eficazes no desempenho de suas funções, uma das necessidades é a de que haja articulação e integração de ações entre estes órgãos, ao contrário do que ocorre hoje (HECK,1996; BORN \& BORN,1999).

Um exemplo de integração e articulação de ações é o projeto Da mata à casa. Conforme foi mencionado nos itens 2.3.- O projeto Da mata à casa e no 2.1 - O Vitae Civilis. Esse projeto procura integrar a pesquisa cientifica com a ação junto aos diferentes atores sociais envolvidos. Esse projeto engloba a pesquisa orientada à ação, que consta do levantamento do saber etnobotânico dos extratores e produtores de plantas medicinais da região do Vale do Ribeira - parte da tese ora apresentada - e estudos do manejo sustentável de espécies medicinais. Engloba também estudos e acompanhamento de várias questões ambientais, como exploração e comercialização de plantas medicinais, acesso a recursos naturais, selo verde para produtos nãomadeireiros, especialmente plantas medicinais. 
Ressalta-se a abordagem do projeto Da mata à casa que é inovadora. Como exemplo, temos a abordagem da seleção das áreas da pesquisa para o desenvolvimento do manejo sustentável de espécies medicinais, conforme apresentado a seguir. O Vitae Civilis decidiu escolher áreas localizadas em propriedades particulares, em vez de áreas de unidade de conservação, como estação ecológica ou parque. Isso possibilitou ao Vitae Civilis ir passando as informações sobre as técnicas e os dados obtidos aos proprietários das áreas e a outros atores interessados nas atividades de manejo sustentável e comercialização de plantas medicinais, de maneira que os dados e as informações possam ser usados, imediatamente, pelos proprietários. Isso só foi possível pelo tipo de relação entre os proprietários e o Vitae Civilis, que se baseia em transparência e confiança mútua, bem como no conhecimento do contexto daquela região com tantos conflitos fundiários e ambientais.

O projeto Da mata à casa engloba também fornecer subsidios a grupos com desejo de se organizar, como foi o caso da criação e do fortalecimento da Associação dos Extratores e Produtores de Plantas Aromáticas e Medicinais do Vale do Ribeira Aepam (ver item 2.2 - A gênese da Aepam). Ele estimula a criação de parcerias com instituições dos diferentes setores. Assim, por exemplo, parte dos estudos sobre o manejo sustentável das espécies medicinais foi realizada graças a uma parceria estratégica com a ESALQ-USP (BORN, 1997; PAVAN, 1999).

O projeto revelou também a importância de se levar em consideração a capacitação e o treinamento de comunidades rurais interessadas em conservação e uso de plantas medicinais. Para isso, foram realizadas quatro atividades principais: dia de campo; cursos sobre plantas medicinais; reunião interinstitucional e conversas com os interessados na área de pesquisa.

No dia de campo, foram apresentados e discutidos alguns dos métodos utilizados para realizar os estudos sobre manejo sustentável junto a extratores e produtores de plantas medicinais, proprietários de outras áreas, onde estavam sendo realizadas as pesquisas sobre manejo sustentável, técnicos do governo e moradores das comunidades rurais da região do Vale do Ribeira (BORN, 1999a).

$\mathrm{Na}$ reunião interinstitucional, foram reunidos extratores e produtores de plantas medicinais; proprietários das áreas de pesquisa sobre manejo sustentável, técnicos do Ibama e DEPRN; moradores de comunidades rurais, pesquisadores da ESALQ-USP e 
representantes do Vitae Civilis, e nessa ocasião foram apresentados e discutidos o projeto Da mata à casa, a metodologia e os dados obtidos nos estudos de manejo sustentável (BORN, 1997).

Um outro aspecto importante é o apoio a comunidades rurais para que sejam capazes de obter e elaborar uma visão ampla sobre o desenvolvimento, criando um plano para tal, em que o uso de plantas medicinais seja um dos instrumentos. Um exemplo disso também foi proporcionado pelo Vitae Civilis no apoio e na assistência à comunidade do Bairro Guapiruvu, em Sete Barras, SP, e que resultou na Agenda 21 local (VITAE CIVILIS \& AGUA, 1998).

É evidente que é preciso que haja integração e articulação entre os órgãos do governos, as empresas, as instituições de pesquisa e de ensino, as ONGs, ou seja, entre todos os segmentos da sociedade, pois todos são responsáveis pelo início do processo de desenvolvimento sustentável.

Falar na possibilidade de desenvolvimento sustentável em áreas de Mata Atlântica é desafiador por causa da grande degradação já causada à riqueza desse bioma. Essa situação ou realidade leva estudiosos como DEAN (1998) a dizer claramente que:

"Resta tão pouca floresta que nenhuma parte dela pode ser usada para experiências em "desenvolvimento sustentável"; de fato, todas as pretensões dessa ordem em relação à Mata Atlântica devem ser encaradas como jargão e hipocrisia."

Realmente, se for verificada essa situação com rigidez ou pessimismo chega-se a essa conclusão preservacionista do autor acima citado (op. cit.). Mas, como foi dito anteriormente, não podemos usar a rigidez para buscar a sustentabilidade do desenvolvimento, mas sim o equilíbrio e a firmeza. Além disso, grande porcentual da população brasileira vive dentro de áreas remanescentes da Mata Atlântica, onde ainda se encontram elevado índice de endemismo além de diversidade biológica, genética, e cultural. É preciso encontrar alternativas e soluções para os diversos conflitos e necessidades, dentre eles os conflitos decorrentes da preservação e conservação das 
áreas remanescentes de Mata Atlântica e o desenvolvimento sustentável das populações que habitam essas áreas.

\subsection{Da sustentabilidade da extração e comercialização de plantas} medicinais da Mata Atlântica, na região do Vale do Ribeira

A análise da sustentabilidade da extração e comercialização de plantas medicinais realizadas pelos extratores e produtores entrevistados será complementada por outras considerações, além daquelas já realizadas no decorrer desta tese.

A determinação do número de extratores e produtores de plantas medicinais existentes na região do Vale do Ribeira é uma tarefa muito difícil, já que cada agricultor é um potencial extrator, pois quem determina a atividade extrativista, nesse caso, é a necessidade de gerar renda para sustentar a família. Como foi apresentado anteriormente, a atividade de extrator pode ser temporária, pois sua duração depende do mercado e do surgimento de outras atividades que proporcionem obtenção de renda. Outro motivo, também já apresentado, é a questão dos conflitos fundiários e ambientais existentes na região do Vale do Ribeira. Por causa do mercado e da ilegalidade, os extratores geralmente se escondem ou são ocultados.

Os dois panoramas diferentes encontrados em 1995 e em 1997, representam uma pequena amostra das transformações e instabilidades mundiais. O Brasil também sofre com essas transformações e instabilidades. Numa escala menor, a região do Vale do Ribeira sente mais tais problemas, pois apresenta altos indices de mortalidade infantil e analfabetismo, além de apresentar famílias sem nenhuma opção de renda. Essa região apresenta, portanto, fragilidades que dificultam o enfrentamento dos desafios mundiais.

Para analisar as relações existentes entre extratores, produtores, DEPRN, Ibama, Aepam e a conservação das plantas medicinais é necessário considerar tais transformações e a complexidade das questões inseridas nesses relacionamentos. Por exemplo, se consideramos a fiscalização e o controle, o mercado, a sobrevivência das famílias dos extratores e produtores somados à própria natureza humana, as relações mencionadas acima, se tornam ainda muito mais complexas. Mas há evidências da possibilidade de essas relações se tornarem menos emaranhadas. Uma delas é a 
existência de uma das lideranças do Vale do Ribeira, Sr. Carlos Novi. Ele conseguiu, de maneira muito inteligente, reunir representantes dos vários segmentos envolvidos na questão, o que culminou na criação da Aepam. Outra evidência é a existência de projetos integrados como é o caso do projeto Da mata à casa, do Vitae Civilis. Enfim, a articulação sistêmica de atores e temas é a resposta para atuar em situações complexas.

A relação recíproca dos extratores e produtores com os seus clientes, ou seja, para quem eles vendem suas mercadorias, é comandada por um sistema mercadológico caracterizado pela dependência financeira dos menos favorecidos em relação aos mais favorecidos. Essa desigualdade, somada a um código de conivência entre as partes, envolvem questões complexas, profundas e amplas. Entre elas, é possível citar a questão de não haver, freqüentemente, a exigência de comercializar produtos de alta qualidade. Isso é observado desde quando a planta é extraida até a fase de embalagem e transporte para o cliente. É necessário que haja mudança de atitude, que sejam criadas condições de mercado e ética para que a mercadoria seja vendida por um bom preço, isto é, que os benefícios sejam compartilhados, que seja mantida uma alta qualidade de produtos e que a saúde pública seja respeitada.

Além desses aspectos, é necessária também a realização de estudos de mercado, assim como a aplicação de alguns instrumentos econômicos para o equacionamento dos problemas ambientais. Por exemplo, entre os instrumentos de mercado é possível citar o selo verde, ou seja, a certificação ambiental de produto e processo.

Para isso, é necessário haver cursos de treinamento e capacitação dos extratores e produtores da região do Vale do Ribeira. Tais cursos são semelhantes àqueles já realizados pelo projeto Da mata à casa, que visaram contribuir para a capacitação da população local para o uso das riquezas da região.

Em relação às plantas extraídas, como foi visto no decorrer desta tese, os entrevistados já exploram um número considerável de espécies medicinais nativas do Brasil, que foram pouco estudadas no meio científico, quando comparado com o das espécies introduzidas. Apesar disso, foi demonstrado também que há um potencial de mercado e de diversidade de espécies medicinais, que os entrevistados ainda não exploram (ver item 5.3.5 - Correlações entre dados). 
São incipientes os estudos científicos com as espécies medicinais nativas. Isso ocorre em vários campos. Dentre eles, destacam-se o estudo da ação farmacológica, da propriedade fitoquímica e do manejo sustentável.

No que concerne ao manejo sustentável de espécies medicinais, num breve levantamento junto a instituições de pesquisa e de ensino superior de vários Estados do Sudeste e do Sul, o Vitae Civilis, durante o desenvolvimento do projeto Da mata à casa, verificou que há basicamente três grupos, apenas, que realizam tais estudos:

- grupo do próprio Vitae Civilis, que liderou e estimulou essa linha de pesquisaação no Vale do Ribeira, desde 1989;

- grupo da ESALQ-USP, em parceria com o Vitae Civilis,

- grupo da Universidade Federal de Santa Catarina.

São poucos os grupos de pesquisadores que tratam desse tema, em relação à quantidade de espécies medicinais nativas já comercializadas. Tal situação decorre da complexidade existente para realizar esses estudos, seja por causa do tempo exigido pelas técnicas da ciência da engenharia florestal seja pela falta de uma metodologia padronizada para a realização de tais estudos. Uma das razões é que a engenharia florestal se desenvolveu com base na necessidade de estudar o manejo de espécies madeireiras e a maioria das espécies medicinais não pertence a esse grupo. Desta forma, demandam o uso de outros indicadores para uma avaliação de manejo.

Comparando o número de plantas citadas pelos extratores e produtores entrevistados que foram identificadas até o nível de espécie, com as 10 espécies que estão sendo estudadas, verifica-se que estamos muito longe de atingir o desejável. $\mathrm{O}$ desejável não é apenas realizar estudos científicos de manejo sustentável de espécies medicinais, mas também que tais estudos sejam realizados de maneira que os extratores e produtores, assim como os outros atores interessados no assunto, se envolvam de maneira a possibilitar o uso dos resultados obtidos. $\dot{E}$ evidente que é crucial o comprometimento sério e leal de todos os atores envolvidos, inclusive o dos compradores.

A questão legal tem um papel muito importante na região, pois $68 \%$ da área da região estudada está sujeita às restrições legais da preservação ambiental, já que detém importantes áreas remanescentes de Mata Atlântica. Comparando as 37 espécies listadas na Portaria DEPRN, $\mathrm{n}^{\circ} 52$, de 1998, entre as quais se encontram espécies exploradas e 
comercializadas para uso não-medicinal, com as 120 espécies medicinais identificadas nesta tese, pode-se concluir que há um longo caminho a ser percorrido, não por causa da diferença numérica, mas principalmente pela complexidade do assunto. Alguns nomes científicos citados na mencionada portaria não coincidem com os identificados no material coletado junto aos entrevistados neste estudo.

No que se refere às áreas de extração das plantas medicinais, os extratores e produtores entrevistados possuem interessante conhecimento sobre técnicas de escolha de área a ser manejada, bem como sobre o próprio manejo tradicional. Para a escolha das áreas de extração e também da planta ou da população a ser submetida ao manejo, eles possuem vários critérios de seleção. No caso da escolha da área, os critérios estão relacionados com indicadores ambientais que determinam a presença ou não da planta desejada. Além disso, os entrevistados utilizam também critérios para verificar a densidade de indivíduos da espécie desejada. Para a seleção da planta ou da população, de uma maneira geral, os critérios mais usados estão relacionados com a quantidade de biomassa existente.

A parte extraída da planta desempenha papel predominante na determinação de vários critérios relevantes para o estudo da sustentabilidade, conforme pode ser verificado na seguinte relação:

1. Aspectos observados na planta que indicam se ela será ou não escolhida;

2. Forma de manejo (como é realizada a extração);

3. Organização do material vegetal a ser transportado (forma de transporte);

4. Forma de triagem;

5. Processo de secagem;

6. Critérios de controle de qualidade.

Observou-se também, que os entrevistados possuem técnicas elaboradas para realizar a extração do material vegetal, a secagem, a trituração e especialmente para realizar o controle de qualidade. Ressalta-se que o conhecimento das técnicas pormenorizadas não está distribuído eqüitativamente entre os entrevistados. Alguns deles detém maior conhecimento e, conseqüentemente, detém também maior mercado. Esse dado é interessante quando se observa que, entre eles, há alguns que podem estar aptos para treinar/capacitar outros extratores e produtores, dentro de um plano bem elaborado e desenvolvido em conjunto com eles. Esse plano teria por escopo reverter o 
processo de competição entre os atores, ou seja, procuraria evitar que alguns se sobressaíssem à custa do sentimento de perda e de diminuição de outros, e geraria um ambiente cooperativo para o enfrentamento dos problemas de produção e comercialização.

Apesar de a amostra de extratores e produtores de plantas medicinais da região do Vale do Ribeira ter conhecimento de algumas técnicas de manejo tradicional interessantes, a grande maioria não observa a periodicidade de retorno para extrair em uma mesma área, de uma mesma planta ou de uma mesma população. Outro aspecto importante para se chegar à sustentabilidade do manejo é a quantidade do material extraído, conforme apresentado no item 3.3.1 - Manejo sustentado de plantas medicinais. Esse aspecto, segundo as informações obtidas, também não é levado em conta pelos extratores e produtores entrevistados.

Em ambos os casos, a periodicidade e a intensidade, analogamente à extração da planta correta, é determinada pelo pedido dos clientes, ou seja, quem manda é o mercado.

\subsection{Recomendações e conclusões finais}

Diante do que foi apresentado no decorrer desta tese, recomenda-se o seguinte:

\section{Para a Aepam:}

- Reestruturar-se para avaliação dos objetivos propostos e das ações realizadas;

- Elaborar plano estratégico de ação, ou seja, uma Agenda 21;

- Ter como um dos objetivos principais levar para a associação os extratores de menor posse financeira e permitir que participem das decisões;

- Formar cooperativa com base em objetivos do estatuto: treinar, capacitar, promover, catalisar, fazer parcerias para a realização de trabalhos que visem a compatibilização da conservação da Mata Atlântica com o desenvolvimento sustentável da região; atuar na elaboração de um novo código de ética nos vários setores que englobem mercado, fiscalização e controle do uso de plantas medicinais; divulgar, fazer divulgar e atuar em trabalhos de educação ambiental que objetivem o resgate da cidadania, dos direitos e dos deveres. 
A criação de unidades de conservação é uma estratégia importante para a busca da sustentabilidade do desenvolvimento, pois há, de um lado, áreas especificas que precisam ser preservadas (intocadas/santuários) e, de outro, outras em que ações exemplares e de educação podem ser praticadas desde que haja proteção às diversidades cultural e biológica como as existente na região do Vale do Ribeira. Há, ainda, outras áreas que precisam ser conservadas, podendo, portanto, ser usadas de forma a preservar o equilíbrio ecológico. Para que isso possa ocorrer, é necessário que as comunidades locais, assim como as autoridades, tanto locais como regionais (prefeitos, vereadores, técnicos do governo, empresas, ONGs, pesquisadores, entre outros), tomem ciência dessa necessidade e mudem atitudes e hábitos.

A existência de instrumentos legais, apenas, não é suficiente, pois a aplicação de tais instrumentos pode ser uma questão muito polêmica e controvertida. Isso ocorre, não por causa do instrumento em si, mas pela maneira como tais instrumentos são aplicados. Para essa questão, foi tomado como exemplo o caso da Estação Ecológica de JuréiaItatins, pois esse caso se tornou polêmico por causa dos grandes e graves conflitos existentes na área, o que levou a indicações de certos cuidados que deveriam ser levados em conta para a criação e a administração de uma unidade de conservação com famílias vivendo na área.

É bem conhecido que a Juréia-Itatins é uma das áreas remanescentes de Mata Atlântica muito importante para a conservação desse bioma. Nessa unidade de conservação se encontram áreas que precisam ser preservadas, ou seja, que não podem sofrer nenhuma ação antrópica. Há outras, entretanto, que podem ser utilizadas em pesquisas desde que sejam observados critérios predeterminados. Há, ainda, outras áreas que podem ser conservadas, ou seja, que podem sofrer ação antrópica de maneira adequada para manter o equilíbrio ecológico e respeitar as áreas de preservação permanente, de forma que as comunidades tenham condições de vida digna. Isso significa que as comunidades podem gerir a área junto a instituições como ONGs e o órgão governamental responsável pela administração. Para isso ocorrer é crucial que as comunidades estejam muito conscientes dessa necessidade e sejam responsáveis pelos seus atos. O órgão governamental responsável pela administração não pode ter uma posição policialesca ou de tutor (ou seja de um grande pai poderoso e autoritário). 
Diante do apresentado e também da necessidade do próprio governo respeitar a legislação ambiental, apesar de suas ambigüidades, a Juréia-Itatins, assim como outras unidades de conservação que estão na mesma situação, precisa ter seu plano de manejo, elaborado de forma participativa com todos os atores envolvidos e, a partir desse plano, precisa ser redesenhada para criar um mosaico de unidade de conservação (BORN et al, 1989). Em relação às comunidades tradicionais da Juréia-Itatins, há evidência de que, se forem envolvidas de maneira respeitosa, digna, democrática e responsável, compreenderão, se for necessário, a transferência de algumas áreas especificas. É evidente que a remoção de comum acordo, é melhor do que a "expulsão dos moradores" de maneira arbitrária. Por exemplo, quando o projeto Juréia-Itatins (ver item 2.1 - O Vitae Civilis) foi iniciado, em 1989, havia 9 familias na comunidade da Cachoeira do Guilherme e, em 1995, havia apenas 4 famílias. Segundo depoimentos dos moradores, a causa da migração das famílias foi atribuida principalmente às restrições impostas, justificadas como sendo necessárias para conservar a área.

\section{Para a sociedade civil brasileira:}

Toda a população brasileira é responsável pela a busca da sustentabilidade do desenvolvimento desse País, o que inclui regiões, municípios e comunidades, mesmo que estejam geograficamente distantes. Portanto, essa sociedade e principalmente as lideranças (formadoras de opinião) devem exigir do mercado produtos com melhor qualidade e a indentificação de produtos provenientes de manejo sustentável realizado

por comunidades rurais que vivem em áreas de conservação, como as encontradas na região do Vale do Ribeira.

\section{Para as empresas (empresários):}

Todas as empresas, especialmente as nacionais, que trabalham com plantas medicinais, deveriam se envolver diretamente, procurar identificar a origem da matériaprima recebida, se provém de manejo sustentável ou não; se realizada ou não, por comunidades rurais que habitam as áreas onde se encontram tais plantas.

Apoiar e financiar pesquisas para a obtenção de dados, assim como trabalhos junto as comunidades, que são de extrema importância para a busca da sustentabilidade do desenvolvimento da região do Vale do Ribeira. 
Para os extratores e produtores:

O Vitae Civilis já vem propondo, há anos, a criação de um centro de treinamento e capacitação para o desenvolvimento sustentável na região do Vale do Ribeira. Fica aqui mais uma vez enfatizada essa necessidade.

\section{Estudos a serem realizados:}

- Enriquecimento de áreas com espécies de plantas que apresentem freqüência de ocorrência baixa. De maneira geral, isso foi verificado para a pata-de-vaca e a espinheira-santa no projeto Da mata à casa;

- Estudos de relações dessas espécies com os animais;

- Expandir os estudos de manejo sustentável para outras espécies;

- Estudar técnicas de beneficiamento (triagem, secagem, trituração, embalagem), transporte do material e armazenagem. Esses estudos, bem como os que tratam do manejo sustentável, mencionado anteriormente, devem ser realizados passo a passo com o extrator e produtor, para buscar a lógica por eles considerada e não apenas o uso de dados do manejo tradicional em pesquisas que se valem de métodos da ciência florestal. É preciso enfatizar que os estudos sobre manejo sustentável das espécies medicinais devem estar apoiados na lógica do extrator e também nos métodos da Engenharia Florestal.

Com base no que foi apresentado e discutido em todo o decorrer do presente trabalho, pode-se concluir que as plantas medicinais, atualmente, não são usadas como um dos instrumentos para a sustentabilidade do desenvolvimento na região do Vale do Ribeira. Entretanto, há alguns atores sociais, como o Vitae Civilis, que atuam nessa região, que estão contribuindo para que as plantas medicinais, assim como outros recursos naturais renováveis, possam vir a ser instrumentos para a sustentabilidade do desenvolvimento. Há evidências, também, de que as plantas medicinais poderão ser um dos instrumentos para a busca dessa sustentabilidade.

Espero que esta tese contribua para a continuação e a realização de ações necessárias para um melhor uso e uma melhor comercialização de plantas medicinais da Mata Atlântica, de forma a conservar esse bioma e a conseguir um desenvolvimento sustentável na região do Vale do Ribeira. 


\section{REFERÊNCIAS BIBLIOGRÁFICAS}

ABRAMO, P. Pesquisa em Ciências Sociais. In: HIRANO, S. (Org.) Pesquisa Social: Projeto e Planejamento. 2..ed. São Paulo(SP):T. A. QUEIROZ, 1988. p.21-88.

ADAMS, C. Caiçaras na Mata Atlântica: Pesquisa Científica versus Planejamento e Gestão ambiental, 1996. 2930. Tese (Mestrado em Ciência Ambiental) - Programa de Pós-graduação em Ciências Ambiental, Universidade de São Paulo.

AKERELE, O; HEYWOOD, V.; SYNGE, H. (Ed.). Conservation of Medicinal Plants. Sydney: Cambrige Press, 1991. p.66-75.

AlBUQUERQUE, J. M. Plantas Tóxicas no Jardim e no Campo, FCA - Serviço de Documentação e Informação, Belém, 1980. 120p.

ALEXIADES, M. N (Ed.) with assistance from Jennei Wood Sheldon. Selected Guidelines for Ethnobotanical Research: A Field Manual. New York: The New York Botanical Garden,. 1996. 5-18p.

ALTIERI, M. A. \& MERRICK, L. C. Agroecologia e conservação in situ da diversidade de plantações nativas no terceiro mundo. In: WILSON, E. O. (Org.), Biodiversidade. Rio de Janeiro (RJ): Nova Fronteira, 1997.

AMOROZO, M. C. M. A Abordagem Etnobotânica na Pesquisa de Plantas Medicinais. In: DI STASI, L. C. (Org.) Plantas Medicinais: Arte e Ciência. São Paulo (SP): Ed. da Universidade Estadual Paulista - (UNESP), 1996. p.47-68.

ARAÚJJO, A. M. Medicina Rústica. 3. ed. São Paulo (SP): Nacional, 1979. 301p.

BALICK, M. \& COX, P.A Plants, People and Culture: The Science of Ethnobotany. New York: Scientific American Library/HPHLP, 1997 229p.

BALICK, M. ELISABETSKY, E., LAIRD, S (Ed.). Medicinal resources of the tropical forest: biodiversity and its importance to human health. New York: Columbia Press, 1996. 440p.

BERNARD, H. R. Research Methods In: Cultural Anthropology. Sage, New-Bury Park, California, 1988.

BICHIR, A. Encefalite Por Arbovírus nas Regiões do Vale do Ribeira, Baixada Santista e Municipios limítrofes, São Paulo, Brasil, período de 1983/1993. Situação do Diagnóstico Etiológico e Características Epidemiológicas, 1995. 73p. Tese 
(Mestrado em Saúde Pública) - Faculdade de Saúde Pública, Universidade de São Paulo.

BIGARELlA, J. J. Aspectos físicos da paisagem. In: CAMARA, I. DE G (Ed.). Mata Atlântica. São Paulo (SP): Index \& Fundação SOS Mata Atlântica, 1991. p.65-88.

BORN G.C.C. (Coord.). Da mata à casa - Parte II: capacitação de atores e uso sustentável de plantas medicinais de Mata Atlântica. São Paulo (SP): Vitae Civilis Instituto para o Desenvolvimento, Meio Ambiente e Paz. Relatório Interno, 1999a. $48 \mathrm{p}$.

BORN G.C.C. (Coord.). Da mata à casa: conservação da biodiversidade e sustentabilidade do uso de plantas medicinais de Mata Atlântica (Vale do Ribeira, São Paulo). São Paulo (SP): Vitae Civilis - Instituto para o Desenvolvimento, Meio Ambiente e Paz. Relatório Interno, 1997. 171p.

BORN, G. C. C. \& FÁVERO, O. A.. A Arte e a Ciência para Organização dos Dados Etnobotânicos. Vitae Civilis - Instituto para o Desenvolvimento, Meio Ambiente e Paz, São Paulo, 1994. 13p.

BORN, G.C.C. \& BORN, R.H. Da mata à casa: formas e alternativas para o controle da exploração e comercialização de plantas medicinais. São Paulo: Vitae Civilis Instituto para o Desenvolvimento, Meio Ambiente e Paz, 1999. 51p.

BORN, G.C.C. \& RODRIGUES, E. A beleza da mata atlântica em arte. São Paulo(SP): Vitae Civilis - Instituto para o Desenvolvimento, Meio Ambiente e Paz, 1998. $59 \mathrm{p}$.

BORN, G.C.C. Da mata à casa: aspectos do mercado de plantas medicinais e aromáticas de São Paulo. - São Paulo: Vitae Civilis-Instituto para o Desenvolvimento, Meio Ambiente e Paz, 1999. 70p.

BORN, G.C.C. Plantas medicinais e etnofarmacologia na mata atlântica. In:

(Coord.) Plantas Medicinais; conservação e desenvolvimento na mata atlântica. São Paulo(SP): Vitae Civilis - Instituto para o Desenvolvimento, Meio Ambiente e Paz, 1998a. p6-36.

BORN, G.C.C. Sátiro às Avessas: Um Líder Espiritual e Político da Juréia-Itatins. São Paulo-SP, Departamento de Antropologia da Faculdade de Filosofia, Letras e Ciências Humanas-FFLCH da Universidade de São Paulo, 1995. 36p. 
BORN, G.C.C. Uso de plantas medicinais no Parque Paulistano (São Miguel Paulista, São Paulo, SP). São Paulo, SP: Vitae Civilis - Instituto para o Desenvolvimento, Meio Ambiente e Paz, 1990. 48p.

BORN, G.C.C.; DINIZ, P.S.N.B. E ROSSI, L. Levantamento Etnofarmacológico e Etnobotânico nas Comunidades da Cacheira do Guilherme e parte do Rio Comprido (sítio Ribeirão Branco - sítio Morrote de Fora) da Estação Ecológica de JuréiaItatins, Iguape. São Paulo: Relatório de consultoria apresentado à Secretaria de Meio Ambiente do Estado de São Paulo-SMA/SP., 1989. 94p.

BORN, G.C.C.; FÁVERO, O.A \& PAVAN, S. EthnobotanIcal Research and Exchange between Vietnam and Brazil: Ethnobotanical projects of the Brazilian Team.. In: JAIN, S. K. (Ed.), Ethnobiology in Human Welfare, New Delhi (India): Deep Publications, 1996a . 362-366p.

BORN, G.C.C.; FÁVERO, O.A \& PAVAN, S. Ethnobotany and Community Development in the Atlantic Rainforest (Brazil). In: JAIN, S. K. (Ed.), Ethnobiology in Human Welfare, New Delhi (India): Deep Publications, 1996. p.460-463.

BORN, G.C.C.; FÁVERO, O.A. \& ROSSI, L. Ethnobotany and Conservation of Cultural and Biological Diversity in the Atlantic Rain Forest Region, Brazil (II). In: III INTERNATIONAL CONGRESS OF ETHNOBIOLOGY - NATURE AND CULTURE; DIRECTIONS FOR CONSERVATION OF DIVERSITY, 1992, Mexico City. Proceeding... Mexico City. p: 27.

BORN, G.C.C.; FÁVERO, O.A.; PAVAN, S. Diagnóstico Etnobotânico e Etnográfico Preliminar, e Definição de Tecnologia em Manejo Sustentado de Plantas Medicinais (Mata Atlântica, Vale do Ribeira, São Paulo). São Paulo (SP): Vitae Civilis Instituto para o Desenvolvimento, Meio Ambiente e Paz. Relatório interno, 1995. $95 \mathrm{p}$.

BORN, R. H. \& BORN, G.C.C. Compensação ou Repartição de Benefícios e outras Questões Técnicas, Éticas e Políticas do Acesso e Uso de Conhecimento das Comunidades Tradicionais. São Paulo(SP): Vitae Civilis - Instituto para o Desenvolvimento, Meio Ambiente e Paz. Trabalho apresentado no Workshop sobre Acesso a Recursos Genéticos, Senado Brasileiro. Brasília(DF), 1996. 10p. 
BORN, R. H. O Processo internacional da Rio-92, seus resultados e produtos (Agenda 21 e Convenções de Clima e de Biodiversidade) e a participação de atores não governamentais: novos valores e instrumentos para a gestão do desenvolvimento humano, 1998. 345p. Tese (Doutorado em Saúde Pública). Departamento de Saúde Ambiental, - Faculdade de Saúde Pública, Universidade de São Paulo.

BORN, R.H.( Vitae Civilis). Proposta de emenda aditiva ao Projeto de Lei $n^{\circ} .2892$, de 1992, que dispõe sobre o Sistema Nacional de Unidades de Conservação. São Paulo (SP): Vitae Civilis - Instituto para o Desenvolvimento, Meio Ambiente e Paz, 1994. $3 \mathrm{p}$.

BORN,G.C.C. et al. Importância e uso de fitoterapia na Aldeia de Carapicuiba, Carapicuiba, SP. In: 41A. REUNIÃO ANUAL DA SOCIEDADE BRASILEIRA PARA O PROGRESSO DA CIÊNCIA. Fortaleza, (CE): 1989a, 17-G.1.10, p.:795.

BRANDÃO, C. R. Participar-pesquisar: In: - (Coord.). Repensando a pesquisa AMAZÔNIA LEGAL. Primeiro Relatório Nacional para a Convenção sobre Diversidade Biológica Brasil. Brasília (DF): Ministério do Meio Ambiente, dos Recursos Hídricos e da participante. São Paulo (SP): Brasiliense, 1984. p.7-14.

BRASIL/ MINISTÉRIO DO MEIO AMBIENTE, DOS RECURSOS HÍDRICOS E DA Amazônia Legal, 1998. 283p.

BREMNESS, L. Herbs, Dorling Kindersley Limited, London, 1994. 304p.

BRITO, A R. M S. Legislação de Fitoterápicos. In: DI STASI, L. C. (Org.) Plantas Medicinais: Arte e Ciência. São Paulo (SP): Ed. da - Universidade Estadual Paulista (UNESP), 1996. p187-197.

BRITO, A R.M.S. \& BRITO, A A S. Forty Years of Brazilian Medicinal Plant Research. Elsevier Scientific Publishers Ireland. Journal of Ethnopharmacology, 39:53-67. 1993.

BRÜSEKE, F. J. O Problema do Desenvolvimento Sustentável. In: CAVALCANTI, C.

(Org.) Desenvolvimento e Natureza: Estudos para uma Sociedade Sustentável. São Paulo(SP), Recife (PE): Cortez ed., Fundação Hoaquim Nabuco, 1995. p.29-40.

CÂMARA, A I. DE G. Plano de Ação para a Mata Atlântica. São Paulo: Interação, 1991. 152p. 
CAMARGO, M. T. L. de A. Medicina Popular: aspectos metodológicos para pesquisa, garrafada, objeto de pesquisa, componentes medicinais de origem vegetal, animal e mineral. São Paulo (SP): ALMED, 1985. 130p.

CANDIDO, A. Os parceiros do rio Bonito: estudo sobre o caipira paulista e a transformação dos seus meios de vida. São Paulo(SP): Duas Cidades, 1998. 284p..

CAPOBIANCO, J.P. Mata atlântica e imprensa. In: Relatório do Laboratório Ambiental para Imprensa. São Paulo(SP):Fundação SOS Mata Atlântica, Fundação Konrad Adenauer, 1994. 89p.

CARLINI, E. A. Pesquisa com plantas brasileiras usadas em medicina popular. Ver. Ass. Brasil, vol 29, maio/jun. 1983, p.109-110.

CHAPELA, I.H. La bioprospección en la era de la información: un análisis crítico de las iniciativas de conservación asociadas com el descubrimiento de nuevos fármacos. In: ORGANIZACIÓN PANAMERICANA DE LA SALUD. Biodiversida, bioteclogía y desarrollo sostenible en salud y agriculuta: conexiones emergentes. Washington, D.C.: OPS, Publicación Científica, 1996. 29-49p.

CICOUREL, A. teoria e método em pesquisa de campo. In: GUIMARÃES , A. Z. Desvendando Máscaras Sociais. 2. ed. Rio de Janeiro (RJ): Francisco Alves, 1980. P.87-121.

COELHO, A. Plantas Medicinais: a natureza que cura. Germinis - Boletim informativo do Conselho Federal de Biologia. Ano 2 no. 11. 1999. p.5.

COMISSÃO MUNDIAL SOBRE MEIO AMBIENTE E DESENVOLVIMENTO. Nosso Futuro Comum. Rio de Janeiro(RJ): ed. da Fundação Getúlio Vargas, 1988. $430 \mathrm{p}$.

CONTE, L. A Shaman Pharmaceuticals' approach to drug development. In: BALICK, M. ELISABETSKY, E., LAIRD, S (Ed.). Medicinal resources of the tropical forest: biodiversity and its importance to human health. New York: Columbia Press, 1996. p.94-100.

CORREAA, M. P. Dicionário de Plantas Úteis do Brasil e das Exóticas Cultivadas, Ministério da Agricultura - IBDF, Rio de Janeiro, 1974. 6 v.

CUNNINGHAM, A B. Professional Ethics and Ethnobotanical Research. In: ALEXIADES, M. N. (Ed.) with assistance from Jennei Wood Sheldon. Selected 
Guidelines for Ethnobotanical Research: A Field Manual. New York: The New York Botanical Garden, 1996. p.19-52.

DEAN, W. A ferro e fogo: a história e a devastação da Mata Atlântica brasileira. Tradução: Cid Knipel Moreira. Revisão técnica: José Augusto Drumond. São Paulo: Companhia das Letras, 1998. 484p.

DIEGUES, A.C.S.A. O mito da natureza intocada. São Paulo : Hucitec, 1996. 169p.

DUTFIELD, G. The public and private domains: intellectual property rights in traditional ecological knowledge. Trabalho apresentado no SEMINÁRIO INTERNACIONAL SOBRE DIREITO DA BIODIVERSIDADE, Brasília (DF), 1999. 22p. (Material mimiografado cedido pelo autor.).

ELISABETSKY, E. \& SETZER, R. Caboclos concepts of disease, diagnosis and therapy; implication for ethnopharmacology and health systems in Amazonia. In: PARKER, E.P. (Ed.). The Amazon Caboclo: Historical and Contemporary Perspectives. Studies on Third World Societies Publication Series, Williamsburgh, v.32, p.243-278,. 1985.

ELISABETSKY, E. \& SHANLEY, P. Ethnopharmacology in the Brazilian Amazon. Great Britain / Pergamon. Pharmac. Ther.(64): 201-214, 1994.

ELISABETSKY, E. Etnofarmacologia de algumas tribos brasileiras. In: DARCY RIBEIRO (Ed.) Suma: etnológica brasileira. Petrópolis ( RJ): Vozes., 1986. p135148.

ENGECORPS \& GOVERNO DO ESTADO DE SÃO PAULO. Macrozoneamento do Vale do Ribeira: Dinâmica sócio-econômica. São Paulo: Engecorps, Governo do Estado de São Paulo, Coordenadoria de Planejamento Ambiental - SMA, 1992. 84p. FANTINI, A. C. et. al. Sustained yield management intropical forest: a proposal based on the autoecology of the species. Sellowia, v.42/44, p.25-33, 1992.

FARNSWORTH, N. R. \& SOEJARTO, D. D. Global Importance of medicinal Plants. : In: Akerele, O; Heywood, V.; Synge, H. (Ed.). Conservation of Medicinal Plants. Sydney: Cambrige University Press, 1991. p26-51.

FARNSWORTH, N. R., AKERELE, O.; BINGEL, A. S.; SOEJARTO, D. D.; GUO, Z. Medicinal plants in therapy. Bulletim of the World Organization, 63 (6):965-981, 1985 
FOOTE-WHYTE, W. Treinando a Observação Participante. In: GUIMARÃES, A. Z. (Org.) Desvendando Máscaras Sociais. 3. ed. Rio de Janeiro: Francisco Alves, 1990. p 77-86.

FUNDAÇÃO SISTEMA ESTADUAL DE ANÁLISE DE DADOS - SEADE, 1996.

Fundação Sistema Estadual de Análise de Dados, - SEADE, 1996.

FUNDAÇÃO SOS MATA ATLÂNTICA \& INSTITUTO NACIONAL DE PESQUISA ESPACIAIS. Atlas da Evolução dos Remanescentes Florestais e Ecossistemas Associados do Domínio de Mata Atlântica do Estado de São Paulo no período de 1985 - 1990. São Paulo: Relatório. Fundação SOS Mata Atlântica, 1993. 46p.

FUNDAÇÃO SOS MATA ATLÂNTICA. 1990.Workshop Mata Atlântica - problemas, diretrizes e estratégias de conservação. In: Anais da Reunião Nacional sobre a proteção dos Ecossistemas naturais da Mata Atlântica. Atibaia, 29 de março a 1 de abril de, 1990, São Paulo: FUNDAÇÃO SOS MATA ATLÂNTICA, 1990.

FUNDAÇÃO SOS MATA ATLÂNTICA; INSTITUTO NACIONAL DE PESQUISAS ESPACIAIS; INSTITUTO SOCIOAMBIENTAL, Atlas da evolução dos remanescentes florestais e ecossistemas associados no domínio da Mata Atlântica no período 1990-1995. São Paulo: Fundação SOS Mata Atlântica; INPE; ISA, 1998. $55 \mathrm{p}$.

GEREZ, J.C,C. \& PEDROSA, D.E.O. Produção de fármacos, questão de sobrevivência. Revista Brasileira de Tecnologia, 18:14-17. 1987.

GIL, A. C. Métodos e Técnicas de Pesquisa Social. 4.ed. - São Paulo: Atlas, 1995, $207 \mathrm{p}$.

GOVERNO DE SÃO PAULO/SECRETARIA DO MEIO AMBIENTE. Brasil 92 Perfil ambiental e estratégias. São Paulo: Secretaria Estadual do Meio Ambiente, 1992.

GOVERNO DO ESTADO DE SÃO PAULO. A batalha do meio ambiente no governo Montoro: apresentação José Pedro de Oliveira Costa. São Paulo: -. 1987, 145p.

GOVERNO DO ESTADO DE SÂO PAULO. Mata Atlântica: ciência, conservação e políticas. Workshop Científico sobre a Mata Atlântica, Belo Horizonte, 22-23 de jan. de 1996. São Paulo: - Secretaria do Meio Ambiente, Governo do Estado de São Paulo. Documentos ambientais. $27 \mathrm{p}$. 
GOVERNO DO ESTADO DE SÂO PAULO. Serra do Mar: uma viagem à Mata Atlântica. São Paulo: Secretaria do Meio Ambiente, Coordenadoria de Educação Ambiental, 1992. 96p. (Educação ambiental).

GOVERNO DO ESTADO DE SÃO PAULO/ SECRETARIA DO MEIO AMBIENTE. Macrozoneamento do Vale do Ribeira: proposta preliminar para a discussão pública. São Paulo: SECRETARIA DO MEIO AMBIENTE/ Coordenadoria de Planejamento ambiental, divisão de Planejamento do litoral, 1997, 55p.

GOVERNO DO ESTADO DE SÃO PAULO/SECRETARIA DO MEIO AMBIENTE.

Atlas of the Environmental Conservation Units in the State of São Paulo. Part 1:

The Coast. São Paulo: - Secretaria do Meio Ambiente, Projeto de Preservação da Mata Atlântica, 1997a.35p.

GRIFO , F,T. Prospección química: una visión general del programa Internacional de Grupos de Cooperación sobre Biodiversidade. IN: ORGANIZACIÓN PANAMERICANA DE LA SALUD. Biodiversida, bioteclogía y desarrollo sostenible en salud y agriculuta: conexiones emergentes. Washington, D.C.: OPS, Publicación Científica, 1996. 12-28p.

GUIMARÃES, P.G. \& MAIA, K. D. Padrões de produção e padrões de consumo: dimensões e critérios de formulação de políticas públicas para o desenvolvimento sustentável. In: FÓRUM BRASILEIRO DE ONGs E MOVIMENTOS SOCIAIS PARA O MEIO AMBIENTE E DESENVOLVIMENTO. Brasil Século XXI: os caminhos da sustentabilidade cinco anos depois da Rio-92. Jean Pierre Leroy, Katia Drager Maia, Roberto Pereira Guimarães (Org.) Rio de Janeiro (RJ): FASE, 1997. P. 385-398.

HECK, M. C. Legislação e Controle na coleta de plantas medicinais. São Paulo (SP):

IBAMA. Palestra proferida no II Workshop de Plantas medicinais de Botucatu (SP), 1415 jun. 1996. 5p.

HOOKER \& JACKSON. 1895. Index Kewensis, Tonus I e II, Oxon II.

IUCN, PNUMA, WWF. Cuidando do planeta Terra: uma estratégia para o futuro da vida. São Paulo (SP): Governo de São Paulo, 1992. 246p.

JAIN, S. K. Ethnobotany: Its concepts and relevance. Scientific Publishers Jodhpur, 1987. p 1-12.

JANZEN, D. H. Ecologia Vegetal nos Trópicos. São Paulo, EPU: ed. da - Universidade de São Paulo, 1980. (Temas de Biologia - v.7) 
JAROSZEWSKI, J.W. Natural products and drug development. Pharmacy International - February, v.5, n.2, p.27-26, 1984.

JOLY, C.A; LEITÃO FILHO, H.F.; SILVA, S. M. O patrimônio florístico. In: CAMARA, I. de G. Mata Atlântica. São Paulo(SP): Index \& Fundação SOS Mata Atlântica, 1991. p.97-125.

KING, S.R.; CARLSON,T.J.S.; CHINNOCK, J.N.; MORAN, K.; BORGES,J.R. Issues in the Commercialization of Medicinal Plants. Manuscrito - Chapter for Book titled From Plants in the South to Medicines in the North Perspectives on Bioprospecting SUM, Olso, Norway, 1998. 12p.

LAKATOS, E.M \& MARCONI, M.A. Fundamentos de Metodologia Científica. São Paulo: Atlas, 1995

LEPSCH, I.F.; SARAIVA, I.R.; DONZELI, P.I.; MARINHO, M.A; SAKAI, E.; GUILLAUMON, J.R.; PFEIFER, R.M.; MATTOS, I.F.A; ANDRADE, W.S.; SILVA, C.E.F, 1990. Macrozoneamento das terras da região do rio Ribeira de Iguape, SP. Instituto Agronômico, Boletim Científico 19, Campinas (SP): Ilus, 2 mapas. 1990.

LÉVI-STRAUSS, C. O pensamento selvagem. Tradução de Tânia Pellegrini. Campinas (SP): Papirus, 1989.323p.

LIMA, A R.\& CAPOBIANCO, J.P.R. Mata Atlântica: Avanços Legais e Institucionais para sua Conservação. São Paulo(SP): Documentos ISA n.4, 1997, 118p.

LINO, C. F.(Ed.) Reserva da Biosfera da Mata Atlântica - Plano de Ação. São Paulo: Consórcio Mata Atlântica - Universidade Estadual de Campinas. v.1, 1992. 101p.

LORENZI, H. Árvores Brasileiras: Manual de identificação e cultivo de plantas arbóreas nativas do Brasil. Nova Odessa: ed. Plantarum, 1992. 352p.

MAGALHÃES, A. R. Um estudo de desenvolvimento sustentável do nordestes semiárido. In: CAVALCANTI, C. (Org.) Desenvolvimento e Natureza: Estudos para uma Sociedade Sustentável. São Paulo (SP), Recife (PE): Cortez, Fundação Joaquim Nabuco, 1995. p.417-429.

MAGNANINI, A. Mata Atlântica. Rio de Janeiro: - AC\&M. 1984, 80p. 
MALINOWSKI, B. O Objeto, Método e Alcance dessa Pesquisa. In: GUIMARÃES, A. Z. (Org.) Desvendando Máscaras Sociais. 3.ed. Rio de Janeiro: Francisco Alves, 1990.p 39-61.

MANTOVANI, W. Estrutura e Dinâmica da Floresta Atlântica na Juréia, Iguape (SP), 1993. 126p. Tese (Livre Docente em Biociências), Instituto de Biociências, Universidade de São Paulo.

MARTIN, G. J. Ethnobotany: A Methods Manual. London: Chapman \& Hall, People and Plants Conservation, 1995, $267 \mathrm{p}$.

MAXWELL, R.A. The state of the science of drug discovery: An opinion. Drug Develop. Res. 4, p:375-389. 1984.

MIRABELLI, H. \& VIEIRA, V. L. Ocupação e o povoamento do Vale do Ribeira. In: SÃO PAULO (ESTADO, SECRETARIA DE ESTADO DO MEIO AMBIENTE). Programa de Educação Ambiental do Vale do Ribeira. São Paulo: Secretaria do Meio Ambiente, 1992. p.53-84.

MORAN, E. F. O estudo da adaptação humana em ecossistemas amazônicos. In: Walter A Neves (Ed.). Origens, adaptações e diversidade biológica do homem nativo da Amazônia. Belém: MPEG/CNPq/SCT/PR., 1991. p.143-160.

MYERS, N. The primary source: Tropical forests and our future. London: W. W. Norton \& Company, 1992. $416 \mathrm{p}$.

NGUYEN THI QUY. Material for common report of joint project: "Ethnobotanical research and exchange between Vietnam and Brazil". Hanoi (Vietnã): Department of Biology, Hanoi University, 1995. 28p.

NOGUEIRA, ). Pesquisa social; introdução às suas técnicas. São Paulo: - Nacional. $1968,209$.

NÚCLEO DE ESTUDOS POPULACIONAIS-NEPO. Universidade de Campinas -UNICAMP, São Paulo, 1995

ORGANIZACIÓN PANAMERICANA DE LA SALUD. Biodiversida, bioteclogía y desarrollo sostenible en salud y agriculuta: conexiones emergentes. Washington, D.C.: OPS, Publicación Científica, 1996. 247p.

PANIZZA, S. Plantas que curam: cheiro de mato. São Paulo: IBRASA. 1997. 279p. 
PAVAN, S. \& BORN, G.C.C. Zoneamento de Referência para Amostragem Vegetal da Mata Atlântica no Vale do Ribeira. São Paulo (SP): Vitae Civilis - Instituto para o Desenvolvimento, Meio Ambiente e Paz. Relatório interno, 1995. 31p.

PAVAN, S. Métodos de amostragem para manejo sustentado de plantas medicinais de Mata Atlântica no Vale do Ribeira - SP, 1999. 195p.Tese (Mestrado em Ciência Ambiental). Programa de Pós-graduação em Ciências Ambiental, - Universidade de São Paulo.

PAVAN, S. Subsídios para elaboração de um plano de manejo em regime de rendimento sustentado, do patrimônio florestal dos índios Xicrim do Caeté- Pará (Segunda fase)- relatório de Diagnóstico e inventario florestal. CEDI-Centro Ecumênico de Documentação e Informação. Piracicaba-SP. 1994.

PLOTKIN, M. J. P. Traditional Knowledge of Medicinal Plants: The Search for New Jungle Medicines. In: Akerele, O; Heywood, V.; Synge, H. (Ed.). Conservation of Medicinal Plants. Sydney: Cambrige Press, 1991. p53-63.

PLOTKIN, M.J. \& FAMOLARE, L.M (Ed.). Sustainable Harvest and Marketing of Rain Forest Products. Washington: Island Press, 1992. 325p.

POR, F. D. Sooretama. The Atlantic Rain Forest of Brazil. SPB Academic Publishing. The Hague, 1992. 130p.

POSEY, D. \& DUTFIELD, G. Beyond intellectual property: toward traditional resource rights for indigenous peoples and local communities. Singapore: International Development Research Centre., 1996. 303p.

POSEY, D. A. Introdução - Etnobiológica: Teoria e Prática. In: DARCY RIBEIRO (Ed.) Suma: etnológica brasileira. Petrópolis (RJ:) Vozes, 1986, p.15-25.

PRINCIPE, P. P. Valuing the Biodiversity of Medicinal Plants. In: AKERELE, O; HEYWOOD, V.; SYNGE, H. (Ed.). Conservation of Medicinal Plants. Sydney: Cambrige Press, 1991. p.79-124.

QUEIROZ, R. da S. Caipiras Negros no Vale do Ribeira: um estudo de antropologia econômica. Antropologia 1. São Paulo: FFLCH/USP, 1983. 166p.

QUEIROZ, R. da S. Os Negros Caipiras do Vale do Ribeira - Um Estudo de Antropologia Econômica, 1980. Tese (Mestrado em Ciências Sociais), 
Departamento de Ciências Sociais, - Faculdade de Filosofia, Letras e Ciências Humanas, Universidade de São Paulo.

REID, W.V.; LAIRD, S.A; MEYER,C.A; GÁMEZ, R.; SITTENFELD, A; JANZEN, D.; GOLLIN, M.A; JUMA, C. Biodiversity Prospecting. In: BALICK, $M$. ELISABETSKY, E., LAIRD, S (Ed.). Medicinal resources of the tropical forest: biodiversity and its importance to human health. New York: Columbia University, 1996. p.142-173.

REIS, M. S. Manejo Sustentado de Plantas Medicinais em Ecossistemas Tropicais. In: DI STASI, L. C. (Org.) Plantas Medicinais: Arte e Ciência. São Paulo(SP): ed. da Universidade Estadual Paulista (UNESP), 1996. p.199-216.

RODRIGUES, E. Etnofarmacologia no Parque Nacional do Jaú, AM: Botucatu, Revista Brasileira de Plantas Medicinais, v.1, n.1, p:01-14, 1998.

RODRIGUES, E. Identificação botânica. In: G.C.C. BORN (Coord.) Plantas Medicinais; conservação e desenvolvimento na mata atlântica. São Paulo: Vitae Civilis - Instituto para o Desenvolvimento, Meio Ambiente e Paz, 1998. p38-53.

RODRIGUES, R. M. 1989. A Flora Amazônica. CEJUP, Belém. 462p.

SACHS, I. Desenvolvimento Sustentável: cenários futuros em nível global. In: SCHREBER, V. Vias de desenvolvimento sustentável: as dimensões do desafio. Anais do encontro Internacional Fórum Belém: vias de desenvolvimento sustentável - as dimensões do desafio. Belém (PA): - UFPA, NUMA, POEMA, IDESP, 1998. 9-14p. (Poema: n.06).

SACHS, I. Ecodesenvolvimento: Crescer sem Destruir. São Paulo: Vértice, 1986. 207p.

SACHS, I. Estratégias de transição para o século XXI: desenvolvimento e meio ambiente. Trad. Magda Lopes. São Paulo: Studio Nobel, Fundação do Desenvolvimento Administrativo, 1993. 103p.

SAKLANI, A \& JAIN, S.K. Cross-Cultural Ethnobotany of Northeast India. Lucknow:

- Deep Publications, National Botanical Research Institute, 1994, 453p.

SÃO PAULO (STATE). ENVIRONMENT SECRETARIAT. Rio on the road; agenda

21 In: São Paulo's Daily Life. São Paulo: - Envionmental Secretariat, 1997.103p.

SATO, J. Mata Atlântica: Direito Ambiental e a Legislação. São Paulo: Hemus, 1995. $197 \mathrm{p}$. 
SCHEFFER, M.C. Levantamento das possiveis espécies exportadas, de acordo com o nome popular fornecido pelo Ibama no "Relatório naturais exportados através da SUPES/SP" (Guarulhos, mar./dez., 1994). Curitiba (PR): Instituto de tecnologia do Paraná, 1995. 91p.

SCLIAR, M. Do mágico ao social: a trajetória da saúde pública. São Paulo: I\&PM, 1987. $111 \mathrm{p}$.

SECRETARIA DE COMUNICAÇÃO DO PT-SP. Vale do Ribeira: diagnóstico e propostas de desenvolvimento regional. Subsídios para elaboração do programa de governo do Partido dos Trabalhadores eleições estaduais de 1998. São Paulo: Secretaria de Comunicação do PT-SP., 1998. 28p.

SILVA, J. A; GONÇAVES, R.B.MN.; GOLDBAUM, M. Atenção primária da Saúde: avaliação da experiência no Vale do Ribeira. Brasília (DF): Centro de Documentação do Ministério da Saúde. (Estudos e Projetos, C 2). 1986. 173p.

SILVA, M. F. et. al. Nomes vulgares de plantas amazônicas. INPA, Belém, 1977. 222p. STAHEL, A. W. Capitalismo e Entropia: Os aspectos ideológicos de uma contradição e a busca de alternativas sustentáveis. In: CAVALCANTI, C. (Org.) Desenvolvimento e Natureza: Estudos para uma Sociedade Sustentável. São Paulo(SP); Recife (PE): Cortez, Fundação Joaquim Nabuco, 1995. p.104-127.

STEPHAN \& AMENDA, T. Espacios sin habitantes?: Parques Nacionais de América del Sur. UICN. Editorial Nueva Sociedad, 1992. 456-472p.

SVENDSEN A. B. \& SCHEFFER, J. J. C. Natural products in therapy: Prospects, goals and means in modern research. Pharmaceutish Weekblad Scientific Edition.v.4, 1982. p.93-103.

SWANSON, T M. (Ed.) Intellectual property rights and biodiversity conservation: na interdisciplinary analysis of the values of medicinal plants. United Kingdom: Cambridge Press, 1998. 271p.

TOLEDO, V. M. What is Ethnoecology? Origins, scope and implications of a rising discipline. Etnoecológica, v.1, n.1, abr. 1992, p.5-21.

VENTURA, W. J. \& RAMBELLI, A.M. Legislação Federal sobre o Meio Ambiente. Taubaté (SP): Vana, 1996. 1148p.

VIEIRA, L. S. 1992. Fitoterapia da Amazônia: Manual das plantas medicinais. ed. Agronômica Ceres, 2.ed., São Paulo (S.P). 347p. 
VITAE CIVILIS \& AGUA. Agenda 21 do Bairro Guapiruvu (Vale do Ribeira, SP.). Sete Barras (SP): Vitae Civilis-Instituto para o Desenvolvimento, Meio Ambiente e Paz \& AGUA-Associação dos Amigos e Moradores do Bairro Guapiruvu, 1998. $41 \mathrm{p}$.

VITAE CIVILIS. Direito de uso de recursos naturais e de propriedade intelectual: o caso Juréia. São Paulo: Vitae Civilis -Instituto para o Desenvolvimento Meio Ambiente e Paz. Relatório interno. 1995. 325p.

VITAE CIVILIS. Plataforma Ambiental Mínima para o Desenvolvimento Sustentável do Vale do Ribeira. São Paulo(SP): Vitae Civilis-Instituto para o Desenvolvimento, Meio Ambiente e Paz. Documento Final do Seminário sobre Plataforma Ambiental Mínima para o Desenvolvimento Sustentável do Vale do Ribeira: Agenda 21 para o Vale do Ribeira, 1995a 18p.

VITAE CIVILIS. Living in the Atlantic Rainforest: Towards Community Intellectual Property Rights in Brazil. In: Paul WOLVEKAMP (Ed.) Forests for the Fture: Local Strategies for Forest Protection, Economic Welfare and Social Justice. New York. Zed Books. 1999. p.113-127. 


\section{Lista de abreviaturas e símbolos}

Aepam: Associação de Extratores e Produtores de Plantas Aromáticas e Medicinais do Vale do Ribeira

APA: Áreas de Proteção Ambiental

ARIE: Área de Especial Interesse Científico

ASPE: Área sob Proteção Especial.

CPDSA21: Comissão Nacional de Política do Desenvolvimento Sustentável e Agenda 21.

DEPRN: Departamento Estadual de Proteção de Recursos Naturais.

FSC: Forest Stewardishp Council International.

Funbio: Fundo Brasileiro de Biodiversidade.

Ibama: Instituto Brasileiro de Meio Ambiente e dos Recursos Naturais Renováveis.

PNUD: Programa das Nações Unidas para o Desenvolvimento.

Pronabio: Programa Nacional de Diversidade Biológica.

SMA-SP: Secretaria Estadual do Meio Ambiente.

SNUC: Sistema Nacional de Unidades de Conservação.

NUPAUB: Núcleo de Apoio à Pesquisa sobre Populações Humanas e Áreas Úmidas Brasileiras, Universidade de São Paulo.

ONG: Organização não governamental.

USP: Universidade de São Paulo.

PNUMA: Programa das Nações Unidas para o Meio Ambiente.

CNUMAD-92: Conferência das Nações Unidas sobre Meio Ambiente e Desenvolvimento

INC: Instituto Nacional do Câncer dos Estados Unidos da América.

ESALQ-USP: Escola Superior de Agronomia Luiz de Queiroz, da Universidade de São Paulo. 


\section{Lista de figuras e esquemas}

Figura 1. Remanescentes florestais no domínio da Mata Atlântica. Fonte LIMA \& CAPOBIANCO(1997) \& FUNDAÇÃO SOS MATA ATLÂNTICA et al., 1998)

Figura 2. Localização da região Vale do Ribeira no Estado de São Paulo. Fonte: BICHIR (1995)

Figura 3. Localização das áreas de extração das plantas medicinais citadas pela amostra de extratores e produtores da região do Vale do Ribeira, SP.

Esquema 1. Possíveis estudos com plantas medicinais. Fonte: BORN (1998), baseado em Carlini (1983) e Elisabetsky \& Setzer (1985).

Esquema 2. Relações comerciais entre os segmentos do mercado de plantas medicinais da região metropolitana de São Paulo. Extrator (mateiro, raizeiro ou erveiro) extrai as plantas que ocorrem espontaneamente em áreas naturais; Produtor (fazendeiro) cultiva, beneficia e comercializa as plantas; Intermediário compra de extratores e de produtores, estoca e vende para outros; Atacadista, semelhante ao intermediário, sendo que compra em quantidades maiores; Farmácias inclui também as de manipulação e homeopáticas. Fonte: BORN, 1999. 


\section{Lista de fotos}

Foto 1. Capitiu, Renealmia petasites Gagnep.

Foto 2. Uma das propriedades onde o Vitae Civilis está realizando estudos sobre o manejo sustentável de espécies medicinais.

Foto 3. Extrator participando no processo de herborização das amostras das plantas coletadas.

Foto 4. Modelo de exsicata para a identificação da planta e posterior inclusão nos herbários do Vitae Civilis e do Instituto Botânico do Estado de São Paulo.

Foto 5. Material vegetal secando ao sol, no chão.

Foto 6. Material vegetal secando ao sol, em bandejas.

Foto 7. Forno fechado de manuseio externo.

Foto 8. Sistema de ventilação do forno fechado

Foto 9. Forno fechado redondo.

Foto 10. Máquina de trituração de plantas medicinais.

Foto 11. Material seco e fragmentando, apresentando diferentes colorações de acordo com a planta correspondente. Este é um dos critérios usados pelos entrevistados para controlar a qualidade do produto final.

Foto 12. Material vegetal armazenado em tambores hermeticamente fechados. 


\section{Lista de gráficos}

Gráfico 1 - Verificação da amostragem dos extratores e produtores de plantas medicinais da região do Vale do Ribeira, SP

Gráfico 2 - Situação da identificação botânica das plantas medicinais.

Gráfico 3 - Freqüência de ocorrência das famílias das plantas citadas.

Gráfico 4 - Número médio de fichas de manejo tradicional por planta dos dois grupos das mais e menos citadas pela amostra dos extratores e produtores de plantas medicinais da região do Vale do Ribeira, SP

Gráfico 5 - Origem das espécies medicinais.

Gráfico 6 - Relação entre a origem e estudos sobre ações farmacológicas e propriedade fitoquímica das espécies nativas e introduzidas.

Gráfico 7 - Média de Estudos farmacológicos e fitoquímicos por espécie citada.

Gráfico 8 - Freqüência dos hábitos das plantas citadas e identificadas pela amostra dos extratores e produtores de plantas medicinais da região do Vale do Ribeira, $\mathrm{SP}$

Gráfico 9 - Periodicidade de retorno às áreas de extração.

Gráfico 10 - Periodicidade de extração das plantas medicinais.

Gráfico 11 - Períodos do dia para a extração de plantas medicinais.

Gráfico 12 - Épocas de extração das plantas medicinais.

Gráfico 13 - Plantas vendidas secas e frescas, segundo a amostra dos extratores e produtores de plantas medicinais da região do Vale do Ribeira, SP.

Gráfico 14 - Compradores e preços das plantas citadas pela amostra dos extratores e produtores de plantas medicinais da região do Vale do Ribeira, SP... 


\section{Lista de tabelas}

Tabela 1 - Plantas citadas pela amostra de extratores e produtores de plantas medicinais da região do Vale do Ribeira, SP.: nome popular, família e no me científico.

Tabela 2 - Plantas citadas pela amostra de extratores e produtores de plantas medicinais da região do Vale do Ribeira, SP: nome científico, família e nome popular.

Tabela 3 - Plantas citadas pela amostra de extratores e produtores de plantas medicinais da região do Vale do Ribeira, SP: família, nome popular e nome científico.

Tabela 4 - Plantas mais citadas pela amostra de extratores e produtores de plantas medicinais da região do Vale do Ribeira, SP, com respectivas partes extraídas e forma de manejo tradicional

Tabela 5 - Origem, uso popular e estudos sobre ação farmacológica e fitoquímica das espécies mais citadas pela amostra de extratores e produtores de plantas medicinais da região do Vale do Ribeira, SP.

Tabela 6 - Hábito, ocorrência e hábitat das plantas mais citadas pela amostra dos extratores e produtores de plantas medicinais da região do Vale do Ribeira, SP.

Tabela 7 - Locais de extração e citações correspondentes, de acordo com os depoimentos da amostra de extratores e produtores de plantas medicinais da região do Vale do Ribeira, SP.

Tabela 8 - Plantas mais citadas, seus indicadores ambientais e respectivas citações.

Tabela 9 - Fatores observados como indicadores ambientais da presença das plantas.

Tabela 10 - Periodicidade de retorno às áreas de extração, segundo a amostra dos extratores e produtores de plantas medicinais da região do Vale do Ribeira, SP.

Tabela 11 - Periodicidade de extração das plantas e suas citações, segundo a amostra dos extratores e produtores de plantas medicinais da região do Vale do Ribeira, SP. 
Tabela 12 - As partes extraídas das plantas e suas respectivas citações pela amostra dos extratores e produtores de plantas medicinais da região do Vale do Ribeira, SP.

Tabela 13 - Correlações entre as partes extraídas e as formas de manejo das plantas citadas pela amostra dos extratores e produtores de plantas medicinais da região do Vale do Ribeira, SP.

Tabela 14 - Aspectos observados na planta para selecionar o indivíduo ou a população a ser submetida ao manejo tradicional das plantas citadas pela amostra dos extratores e produtores de plantas medicinais da região do Vale do Ribeira, SP.

Tabela 15 - Correlação entre a parte extraída e os aspectos observados para selecionar as plantas, segundo a amostra de extratores e produtores de plantas medicinais da região do Vale do Ribeira, SP.

Tabela 16 - Formas de transporte das partes extraídas das plantas citadas pela amostra dos extratores e produtores de plantas medicinais da região do Vale do Ribeira, SP

Tabela 17- Manejo tradicional detalhado e as formas de transporte para as plantas mais citadas pela amostra de extratores e produtores de plantas medicinais da região do Vale do Ribeira, SP.

Tabela 18 - Partes vegetais comercializadas verdes e secas com suas freqüências de citações, segundo a amostra dos extratores e produtores de plantas medicinais da região do Vale do Ribeira, SP.

Tabela 19 - Partes vegetais comercializadas secas com a freqüência de citação para a forma de triagem usada pela amostra dos extratores e produtores de plantas medicinais da região do Vale do Ribeira, SP

Tabela 20 - Tipo de material comercializado e formas de comercialização mais comuns para as plantas citadas pela amostra dos extratores e produtores de plantas medicinais da região do Vale do Ribeira, SP...

Tabela 21 - Padrões de fragmentação e suas respectivas citações, segundo a amostra dos extratores e produtores de plantas medicinais da região do Vale do Ribeira, SP

Tabela 22 - Faixas de rendimento das plantas e suas respectivas citações, segundo a amostra dos extratores e produtores de plantas medicinais da região do Vale do Ribeira, SP.

Tabela 23 - Relação entre as partes extraídas e os critérios utilizados para o controle de qualidade das plantas citadas pela amostra dos extratores 
e produtores de plantas medicinais da região do Vale do Ribeira, SP.

Tabela 24 - Tipos de embalagens utilizados para a venda do material comercializado seco ou fresco (plantas citadas) pela amostra dos extratores e produtores de plantas medicinais da região do Vale do Ribeira, SP.

Tabela 25 - Faixa de preço em reais por quilo de material comercializado, os compradores e as respectivas citações, segundo a amostra dos extratores e produtores de plantas medicinais da região do Vale do Ribeira, SP

Tabela 26 - Parte extraída, forma de secagem e de embalagem, rendimento, preço e compradores das plantas mais citadas pela amostra de extratores e produtores de plantas medicinais da região do Vale do Ribeira, SP. 


\section{Lista dos anexos}

ANEXO 1 - LISTA DA FIGURA COMPLEMENTAR

FIGURA 2 - Localização da região Vale do Ribeira no Estado de São Paulo, 228

\section{ANEXO 2 - INSTRUMENTOS LEGAIS}

1. Dos fitoterápicos, 230

2. Da exploração e comercialização de plantas medicinais, 236

\section{ANEXO 3 - INSTRUMENTOS DA PESQUISA}

1. Ficha de levantamento de aspectos sócioeconômico-políticos, 245

2. Ficha de técnicas de manejo tradicional, incluindo aspectos da planta e da área utilizada para a extração, 248

3. Ficha de beneficiamento, controle de qualidade e aspectos da comercialização das plantas, 250

4. Ficha de coleta vegetal, incluindo informações sobre o reconhecimento e identificação botânica das plantas citadas por cada entrevistado, além de outras informações obtidas, 251

5. Ficha de levantamentos bibliográficos, referem-se a estudos publicados sobre fitoquímica e ação farmacológica das espécies levantadas, 252

\section{ANEXO 4 - LISTA DAS TABELAS COMPLEMENTARES}

Tabela 1 - Plantas citadas pela amostra de extratores e produtores de plantas medicinais da região do Vale do Ribeira, SP.: nome popular, família e nome científico, 254

Tabela 2 - Plantas citadas pela amostra de extratores e produtores de plantas medicinais da região do Vale do Ribeira, SP.: nome científico, familia e nome popular, 261

Tabela 3 - Plantas citadas pela amostra de extratores e produtores de plantas medicinais da região do Vale do Ribeira, SP.: família, nome popular e nome científico, 268

Tabela 5 - Origem, uso popular e estudos sobre ação farmacológica e fitoquímica das espécies mais citadas pela amostra de extratores e produtores de plantas medicinais da região do Vale do Ribeira, SP.,275

Tabela 17 - Manejo tradicional detalhado e as formas de transporte para as plantas mais citadas pela amostra de extratores e produtores de plantas medicinais da região do Vale do Ribeira, SP., 283

Tabela 26 - Parte extraída, forma de secagem e de embalagem, rendimento, preço e compradores das plantas mais citadas pela amostra de extratores e produtores de plantas medicinais da região do Vale do Ribeira, SP., 285 
ANEXO 1 - LISTA DA FIGURA COMPLEMENTAR 


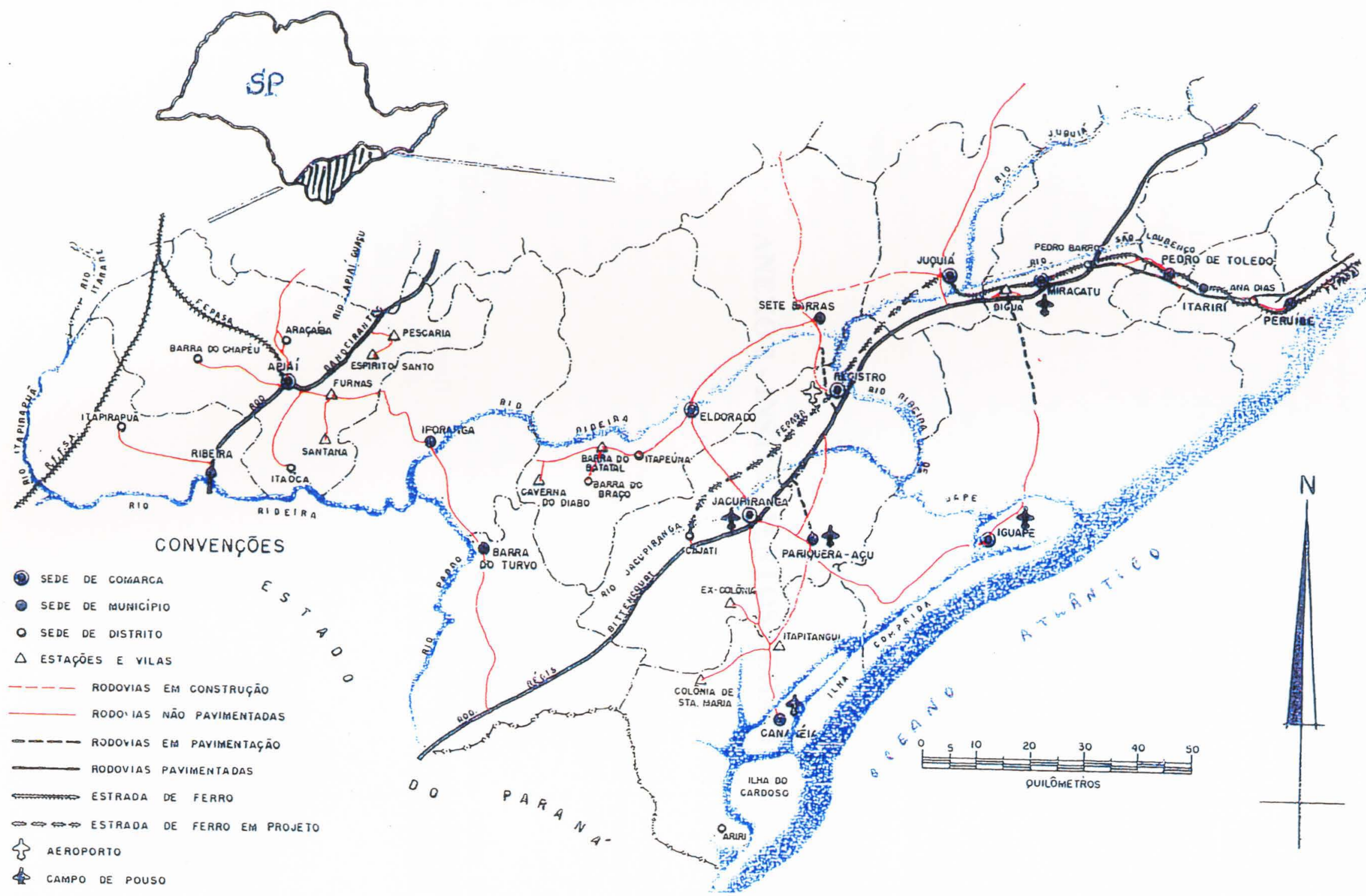

Figura 2. Localização da região Vale do Ribeira no Estado de São Paulo. Fonte: BICHIR (1995) 
ANEXO 2 - INSTRUMENTOS LEGAIS 


\section{Dos fitoterápicos}

A Portaria $\mathrm{n}^{\mathrm{0}}$ 6/ Secretaria de Vigilância Sanitária, de 31 de janeiro de 1995 instituiu e normatizou o registro de produtos fitoterápicos no Sistema de Vigilância Sanitária, conforme as seguintes determinações:

\section{I. - DEFINIÇÕES}

a) Produto fitoterápico: é todo medicamento tecnicamente obtido e elaborado, empregando-se, exclusivamente, matérias-primas ativas vegetais com finalidade profilática, curativa ou para fins de diagnóstico, com benefício para o usuário. É caracterizado pelo conhecimento da eficácia e dos riscos de seu uso, assim como pela reprodutibilidade e constância de sua qualidade; é o produto final acabado, embalado e rotulado. Na sua preparação, podem ser utilizados adjuvantes farmacêuticos permitidos pela legislação vigente. Não podem estar incluídas substâncias ativas de outras origens, não sendo considerado produto fitoterápico quaisquer substâncias ativas, ainda que de origem vegetal, isoladas ou mesmo suas misturas.

b) Matéria-prima vegetal: planta fresca, droga vegetal ou preparado fitoterápico intermediário, empregado na fabricação de produto fitoterápico.

c) Droga vegetal: é a planta ou suas partes, que após sofrer processo de coleta, secagem, estabilização e conservação, justificam seu emprego na preparação do medicamento.

d) Preparado fitoterápico intermediário: é o produto vegetal triturado, pulverizado, rasurado, extrato, tintura, óleo fixo ou volátil, cera, suco e outros obtido de plantas frescas e de drogas vegetais, por operações de fracionamento, extração, purificação ou concentração utilizado na preparação do produto fitoterápico.

e) Principio ativo: substâncias ou grupo delas, quimicamente caracterizados, cuja ação farmacológica é conhecida e responsável total ou parcialmente, pelos efeitos terapêuticos do produto fitoterápico.

f) Marcadores: são constituintes quimicamente definidos, presentes na matériaprima vegetal, preferencialmente os próprios princípios ativos, destinados ao controle de qualidade da matéria-prima vegetal, dos preparados fitoterápicos intermediários e dos produtos fitoterápicos.

\section{II - DA FABRICAÇÃO E COMERCIALIZAÇÃO}

a) A fabricação e a comercialização de produtos fitoterápicos serão feitas somente após autorização de funcionamento da empresa e registro de produtos no órgão competente do Sistema Único de Saúde, de acordo com a Portaria $\mathrm{n}^{\mathrm{o}} 1.585 / \mathrm{MS}$, de 26.8.1994 (DOU de 26.8.1994).

\section{III - DO REGISTRO DE PRODUTO FITOTERÁPICO.}

a) O registro dos produtos fitoterápicos, de que trata a presente norma, será emitido com base na análise e na avaliação do relatório técnico que apresente as seguintes informações:

1 Matéria-prima vegetal

1.1 Planta fresca 
1.1.1. Nomenclatura botânica oficial (gênero, espécie, autor do binômio e família).

1.1.2 Nomenclatura farmacopéia, popular e/ou indígena, com referência à região de origem.

1.1.3 Identificação da matéria-prima com indicação do(s) método(s) empregado(s) e laudo do profissional responsável pela identificação.

1.1.4 Parte da planta utilizada.

1.1.5 Obtenção do vegetal, indicando se cultivado ou não, método de cultivo e de coleta, época e local de coleta, justificando a época de coleta, inspeção visual.

1.1.6 $\mathrm{O}$ produtor deve documentar que está adquirindo sua matéria-prima nos moldes estabelecidos na Portaria IBDF $\mathrm{n}^{\circ}$ : 122-P, de 19.3.1985, que estabelece normas ao registro de pessoas físicas ou jurídicas que consumam, explorem ou comercializem matéria-prima florestal, e Portaria Ibama $\mathrm{n}^{\mathrm{o}}$ : 6-N, de 15.1.1992, que reconhece espécies da flora brasileira ameaçadas de extinção, bem como está em conformidade com as exigências das legislações ambientais estaduais e municipais.

1.1.7 Caracterização organoléptica, macroscópica e microscópica.

1.1.8 Testes de pureza, cinzas, umidade, pesquisa de elementos estranhos, pesquisa de contaminantes microbiológicos e biológicos, metais pesados e agrotóxicos, de acordo com a Farmacopéia Brasileira ou com as recomendações da Organização Mundial de Saúde. Em caso de utilização de métodos para eliminação de contaminantes, descrever o método e pesquisa de eventuais alterações na matéria-prima.

1.1.9 Análise qualitativa e quantitativa de princípios ativos, quando conhecidos.

1.1.10 Análise fitoquímica qualitativa dos constituintes característicos da espécie.

1.2 Droga vegetal

1.2.1 Atender às exigências contidas no item 1.1.

1.2.2 Operações empregadas: método de secagem, estabilização, conservação, contaminação e tamisação.

1.2.3 No caso de utilização de droga vegetal importada, além das exigências desta norma, deve ser obedecida a legislação do comércio exterior.

1.3 Preparado fitoterápico intermediário

1.3.1 Atender às exigência contidas nos itens de 1.1.1 a 1.1 .4 e de $1.1 .7 \mathrm{a}$ 1.1.10.

1.3.2 Especificar a origem e caracterizar o preparo fitoterápico intermediário, considerando os itens 1 e 2 pertinentes.

1.3.3 Características físicas e físico-químicas.

\section{Produto fitoterápico}

2.1 Atender aos itens 1.1.1 a 1.3.3.

2.2. Indicar a concentração real, em peso ou volume da matéria-prima vegetal e a correspondência em marcador ou em princípio ativo, quando conhecidas.

2.3 Indicar a fórmula completa de preparação do produto fitoterápico, com todos os seus componentes especificados pelos seus nomes técnicos, de acordo com as DCBs correspondentes e sinônimos, as quantidades de cada 
substância expressa no sistema métrico decimal ou na unidade-padrão, consignando as substâncias usadas como adjuvantes.

2.4 Descrever critérios de identificação do lote ou da partida.

2.5 No caso de inexistência de metodologias químicas compatíveis para o controle de qualidade, este deverá ser baseado na ação farmacológica preconizada.

2.6 No caso da ação farmacológica do produto fitoterápico ser devida a grupo de substâncias, devem ser considerados os componentes mais indicativos do efeito terapêutico.

2.7 Somente será permitida a importação de produto fitoterápico se esta norma e legislação vigente forem cumpridas.

2.8 Processo de fabricação, com a descrição precisa das operações a serem realizadas, os pontos e métodos de controle de processamento, o relatório descritivo do controle de qualidade realizado, assim como os testes de estabilidade e físico-químicos do produto acabado, em seu material de acondicionamento original.

2.9 Indicar, comprovando por métodos biológicos, químicos e outros pertinentes, o prazo de validade e os cuidados de armazenagem e transporte.

3 Segurança e eficácia terapêutica do produto fitoterápico.

3.1 Apresentar estudos científicos que comprovem a seguranca e a eficácia terapêutica do produto fitoterápico, de acordo com exigências estipuladas na Resolução n ${ }^{\circ} 1 / 1988$ do CNS (grifo nosso):

- toxicologia pré-clínica;

- toxicologia clínica.

3.2 Apresentar estudos científicos que comprovem a eficácia terapêutica do produto fitoterápico, de acordo com as exigências estipuladas na Resolução $\mathrm{n}^{\circ} 1 / 1988$ do CNS (grifo nosso):

- farmacologia pré-clínica;

- farmacologia clínica, estabelecendo a relação dose/atividade;

- definir o conjunto de indicações terapêuticas, adequadamente nominadas;

- apresentar contra-indicações, restrições de uso, efeitos colaterais e reações adversas para cada fórmula farmacêutica.

\section{IV - DA REVALIDAÇÃO DE REGISTRO DOS PRODUTOS FITOTERÁPICOS JÁ COMERCIALIZADOS.}

a) Em razão da definição de produto fitoterápico constante desta norma, do fato de que inúmeros produtos foram registrados em épocas cujo conhecimento científico era incipiente, da necessidade de rever processos e adequá-los aos requisitos de segurança, eficácia e qualidade, a revalidação dos produtos fitoterápicos obedecerá os seguintes requisitos:

1 Atender a todos os requisitos expressos nesta norma, referentes ao registro do produto fitoterápico.

2 Após a publicação desta portaria, a empresa deverá apresentar necessariamente para revalidação do registro: 
- em prazo máximo de 5 anos, os estudos sobre toxicidade do produto, de acordo com o item 3.1 desta norma;

- em prazo máximo de 10 anos, os estudos de comprovação da eficácia do produto, segundo o item 3.2 desta norma.

3 Neste interstício, as bulas e os rótulos deverão conter, obrigatoriamente, os seguintes dizeres: "PRODUTO EM ESTUDO PARA AVALIAÇÃO CIENTÍFICA DAS INDICAÇÕES TERAPÊUTICAS E DA TOXICIDADE. O USO DESTE PRODUTO ESTÁ BASEADO EM INDICAÇÕES TRADICIONAIS."

4 Fica concedido prazo máximo de 6 meses para alterações das embalagens.

4.1 Todos os produtos fitoterápicos, registrados na Secretaria de Vigilância Sanitária/MS, terão sua autorização de comercialização por cinco anos a partir da data de publicação desta portaria.

4.2 Se neste interstício for observada toxicidade do produto, serão tomadas as medidas previstas na legislação vigente.

$5 \mathrm{O}$ não atendimento ao anteriormente estabelecido impedirá a revalidação do registro.

\section{V - DA ISENÇÃO DE REGISTRO}

a) A isenção de registro de produto fitoterápico será concedida por meio de cadastramento do produto no órgão competente do Ministério da Saúde, nos casos especificados no Artigo 23 da Lei nº 6.380 e no Artigo 28 do Decreto $n^{0} 79.094$ e após avaliação de relatório técnico que forneça:

1 A Monografia da Farmacopéia ou código oficial aceito onde a espécie vegetal e/ou o produto fitoterápico esteja inscrito, com cópia anexa.

2. As informações referentes à ausência da toxicidade, às indicações terapêuticas e ao controle de qualidade de produto fitoterápico que não constarem da Monografia solicitada no item a, devem ser apresentadas, anexando comprovação científica, de acordo com o item 3 desta norma.

b) O número do cadastro deve constar no rótulo do produto fitoterápico.

\section{VI - DA SIMILARIDADE}

a) É considerado nesta norma produto fitoterápico similar àquele que contenha, no mínimo, o(s) mesmo(s) princípio(s) ativo(s), ou, quando não conhecido(s), as mesmas matérias-primas, na mesma concentração, indicação e dose, utilizando a mesma via de administração do produto fitoterápico comprovadamente em uso no país, devendo apresentar:

1 Testes clínicos que comprovem bioequivalência ou testes in vitro, desde que comprovada sua correlação com a biodisponibilidade.

2 Metodologia do controle de qualidade do produto fitoterápico.

\section{VII — DA ROTULAGEM, EMBALAGENS E BULAS}

a) $\mathrm{Na}$ rotulagem deverá constar:

- designação de "Produto Fitoterápico"; 
família);

- nomenclatura botânica oficial (gênero, espécie, autor do binômio e

- parte utilizada da planta;

- não deve conter dizeres que induzam a automedicação, à utilização indevida do produto, ou referências a "Produto Natural ou Congêneres" que dêem ao consumidor a idéia de produto inócuo ou possuidor de propriedades especiais;

- data de fabricação, com número de lote ou partida, e prazo de validade;

- número de registro no Ministério da Saúde ou número de cadastro referente à isenção de registro, quando for o caso; caso;

- os dizeres exigidos pelo item 3, da Alínea a, Inciso IV, quando for o

- quanto à composição do produto, indicar:

1 Concentração do princípio ativo, quando conhecido, na matériaprima ou no produto.

2 A relação real em peso ou volume da matéria-prima vegetal usada e correspondência em marcadores do princípio ativo, quando conhecido.

3 A concentração do(s) componente(s) mais indicativo(s) do efeito terapêutico:

- dados gerais da Empresa: nome, endereço, CGC;

- nome do responsável técnico, número de inscrição e sigla da respectiva categoria profissional;

- é proibida a apresentação de desenhos e figuras nos cartuchos, rótulos e bulas, que induzam a erro ou à confusão, ressalvada a reprodução do logotipo da empresa;

- os demais itens dos dizeres de rotulagem devem obedecer às disposições legais vigentes.

b) Acondicionamento e embalagem:

- material de acondicionamento não pode alterar os efeitos do produto fitoterápico ou produzir danos à saúde;

- material de acondicionamento de embalagem deve ser resistente ao ataque de insetos e outros, e apresentar-se completamente vedado.

c) Bulas

As bulas devem conter o especificado na Alínea a, do Inciso VII, desta norma, com exceção dos dados sobre o número de lote e prazo de validade, e estar de acordo com a legislação vigente.

\section{VIII - DA VALIDAÇÃO DOS MÉTODOS}

a) Em relação aos pedidos de descrição de métodos utilizados em controle de qualidade que não sejam farmacopéicos, estes devem ser acompanhados dos dados de sua validade respectiva, a cargo da empresa produtora.

\section{IX — DA ASSOCIAÇÃO DE ESPÉCIES VEGETAIS} critérios:

a) Só serão registradas associações fitoterápicas que observem os seguintes 
- que apresentem justificativas da associação proposta, com documentação científica que fundamente suas vantagens farmacológicas e terapêuticas;

- que apresentem estudos de segurança de uso da associação, mesmo que tais existam para cada componente em particular;

- que apresentem estudos de estabilidade da associação;

- que os efeitos colaterais e reações adversas, apresentados pela associação, sejam de igual ou de menor intensidade aos de cada componente isolado.

Art. $2^{\underline{0}}$ - Os requisitos de qualidade das matérias-primas vegetais, contidos em medicamentos associados com matérias-primas ativas de outras origens, deverão obedecer o disposto nesta norma, nos aspectos pertinentes.

Art. $3^{0}$ - Para as questões não previstas nesta norma, será aplicada a legislação vigente para medicamentos em geral.

Art. $4^{\underline{0}}$ - Esta portaria entra em vigor na data de sua publicação.

Art. $5^{\circ}$ - Ficam revogadas as disposições em contrário. 


\section{Da exploração e comercialização de plantas medicinais}

A seguir, serão listados e resumidos com comentários breves alguns dos atos legais que dizem respeito à estrutura e ao funcionamento do Ibama, à exploração, à comercialização e ao transporte de plantas medicinais ou de seus produtos, segundo BORN \& BORN (1999).

\section{A) Estrutura e funcionamento do Ibama}

- Lei $\mathbf{n}^{\mathbf{0}} \mathbf{7 . 7 3 5}$, de 22 de fevereiro de 1989 - Dispõe sobre a extinção de órgão e de entidade autárquica, cria o Instituto Brasileiro do Meio Ambiente e dos Recursos Naturais Renováveis, cuja finalidade é assessorar o Ministério do Meio Ambiente, dos Recursos Hídricos e da Amazônia Legal na formação e coordenação, bem como executar e fazer executar a política nacional do meio ambiente e da preservação, conservação e uso racional, fiscalização, controle e fomentos dos recursos naturais.

- Decreto Lei no 289 , de 28 de fevereiro de 1967 - Cria o Instituto Brasileiro de Desenvolvimento Florestal e define as suas atribuições, as quais foram transferidas ao Ibama (Art. $4^{0}$ da Lei $n^{0} 7.735 / 89$ ). De acordo com esse Decreto Lei (Art. $3^{\circ}$ ), o IBDF (leia-se Ibama) deve elaborar planos indicativos, anuais e plurianuais, visando o desenvolvimento de espécies florestais de utilização econômica (Inciso II). De acordo com o Art. 4⿳⺈, compete prioritariamente ao IBDF (leia-se Ibama): prestar assistência técnica e estabelecer princípios e normas visando a utilização racional das florestas (Inciso V); adotar, promover ou recomendar a adoção de medidas que assegurem a manutenção do equilíbrio entre as reservas florestais e o consumo de produtos e subprodutos florestais, visando o perene abastecimento dos mercados consumidores (Inciso VI); e autorizar, orientar e fiscalizar as explorações florestais, no campo da iniciativa privada, bem como planejar e executar as operações correspondentes nas áreas de sua jurisdição (Inciso VII).

Ainda de acordo com esse Decreto Lei (Art. $5^{\underline{9}}$ ), também são competências do IBDF (leia-se Ibama): estabelecer o registro obrigatório e organizar o cadastramento das pessoas fisicas e jurídicas que exerçam atividades relacionadas com o presente Decreto Lei, segundo o disposto no regulamento (Inciso I); organizar e realizar diretamente ou através de outros órgãos públicos, ou entidades de classe, a fiscalização das atividades relacionadas com o presente Decreto Lei, bem como promover a repressão às fraudes em exploração florestal, produto, transporte, comercialização e industrialização de produtos florestais, nos termos e condições estabelecidos pelo Poder Público (Inciso II); e celebrar convênios e acordos com entidades públicas ou privadas, nacionais, internacionais ou estrangeiras, visando o bom desempenho de suas atribuições (Inciso IV).

- Decreto no 97.946, de 11 de julho de 1989 - Dispõe sobre a Estrutura Básica do Instituto Brasileiro do Meio Ambiente e dos Recursos Naturais Renováveis. O Ibama tem por finalidade formular, coordenar, executar e fazer executar a política nacional do meio ambiente e de preservação, conservação e uso racional, fiscalização, controle e fomento dos recursos naturais renováveis (Art. $1^{\circ}$ ), especialmente: propor ao CONAMA o estabelecimento de normas e padrões gerais relativos à preservação e conservação do meio ambiente, visando assegurar o bem-estar das populações e compatibilizar seu 
desenvolvimento socioeconômico com a utilização racional dos recursos naturais (Inciso II); incentivar, promover e executar pesquisas, bem como estudos técnicocientíficos em todos os níveis da sua esfera, difundindo os resultados obtidos (Inciso V); orientar e disciplinar as atividades de fomento florestal (Inciso VII); cadastrar, licenciar, fiscalizar e disciplinar os segmentos produtivos que utilizam matérias-primas oriundas da exploração de recursos naturais (Inciso IX); fazer cumprir a legislação federal sobre meio ambiente e promover a fiscalização das atividades de exploração de florestas e flora, visando sua conservação e seu desenvolvimento, bem como a proteção e melhoria da qualidade ambiental do meio ambiente (Inciso X); promover e disciplinar a utilização dos recursos naturais renováveis e dos produtos e subprodutos decorrentes de sua exploração (Inciso XIII); estabelecer cooperação técnica e científica com instituições nacionais, internacionais e estrangeiras (Inciso XVI); manter, em bancos de dados, as informações essenciais à execução de suas competências (Inciso XVII).

Â Diretoria de Controle e Fiscalização compete planejar, dirigir, coordenar, executar ou fazer executar as atividades de fiscalização, controle, monitoramento e gestão da qualidade ambiental e da utilização dos recursos da flora (Art. $4^{\mathrm{o}}$ ). $\grave{A}$ Diretoria de Recursos Naturais Renováveis compete planejar, dirigir, orientar e coordenar as atividades referentes ao aproveitamento sustentável dos recursos naturais renováveis (Art. $5^{\mathbf{0}}$ ). À Diretoria de Ecossistemas compete planejar, dirigir, orientar e coordenar as atividades relacionadas com a conservação de amostras representativas dos ecossistemas e o manejo da vida silvestre, visando a manutenção da biodiversidade (Inciso $6^{0}$ ). À Diretoria de Incentivo à Pesquisa e Divulgação compete planejar, dirigir, orientar, coordenar e gerenciar as unidades e atividades de pesquisa, educação ambiental e divulgação técnico-científica, bem como promover a inovação e a difusão tecnológica na área ambiental (Art. $7^{\underline{0}}$ ). Às Superintendências Estaduais, administrativamente subordinadas ao Presidente e tecnicamente aos Diretores, compete operacionalizar planos, programas e projetos do Ibama, em sua área de jurisdição (Art. 15). O Instituto poderá celebrar contratos, convênios, acordos e ajustes com organizações públicas e privadas, nacionais, internacionais e estrangeiras, visando a realização de seus objetivos (Art. 24).

- Portaria IBDF nº 377-P, de 9 e junho de 1980 - Delega poderes ao Órgão Ambiental do Estado de São Paulo, ao DEPRN.

\section{B) Exploracão:}

- Instrução Normativa IBDF n⿳0001, de 11 de abril de 1980 - Dispõe sobre a exploração de florestas e de outras formações arbóreas. A exploração de florestas e de outras formações arbóreas depende de autorização prévia do IBDF e obriga a reposição com espécies florestais adequadas, observadas as disposições da legislação pertinente, as peculiaridades regionais e de determinações das respectivas delegacias (Art. $1^{\underline{0}}$ ). $\mathrm{O}$ plantio obrigatório de árvores deve ser feito pelos que utilizem ou venham a utilizar material lenhoso e outros produtos florestais, quer como matéria-prima, quer como combustível ou outra designação (Art. $2^{0}$ ).

- Ordem de Serviço Ibama/SUPES-SP nº 55, de 29 de outubro de 1991 Autoriza a Secretaria do Meio Ambiente do Estado de São Paulo a emitir autorização 
para a exploração de qualquer tipo de formação florestal, prevista na Instrução Normativa Ibama 84/91. Será permitida a supressão da vegetação nativa de Mata Atlântica obedecendo a definição das formas vegetais que constam na Instrução Normativa, obedecidas as seguintes condições (Art. $3^{\underline{0}}$ ): a) quando a vegetação nativa estiver em estágio inicial de regeneração, e a supressão for para fins de atividades agrosilvo-pastoris, até o limite de um módulo rural estabelecido pelo município, para cada familia, proprietários ou posseiros legítimos; b) em áreas urbanas, para fins de edificação; c) nos casos de vegetação nativa nos estágios inicial, médio e avançado de regeneração, a supressão para fins de mineração somente poderá ser autorizada pelo órgão estadual competente, ouvido o Ibama, desde que o minério seja considerado raro e de caráter estratégico de interesse nacional. Será permitida ainda a supressão de vegetação nativa de Mata Atlântica em estágio inicial de regeneração quando se tratar de exploração econômica, cuja área de propriedade exceda a um módulo rural estabelecido pelo município (Art. $4^{\circ}$ ).

- Decreto n⿳0 750, de 10 de fevereiro de 1993 - Dispõe sobre o corte, a exploração e a supressão de vegetação primária ou nos estágios avançado e médio de regeneração da Mata Atlântica (ver item 1. - Instrução ).

- Portaria Ibama no $\mathbf{2 1 8}$, de 4 de maio de 1989 - Normaliza os procedimentos quanto às autorizações de derrubada e exploração florestal envolvendo área de Mata Attântica. A derrubada e exploração de florestas nativas e de formações florestais sucessoras nativas de Mata Atlântica só poderão ser feitas através do plano de manejo de rendimento sustentado, devidamente aprovado pelo Ibama (Art. $1^{\circ}$ ). A Diretoria de Recursos Naturais Renováveis do Ibama estabelecerá critérios para elaboração dos planos de manejo de que trata este artigo ( $\S$ único).

- Portaria Ibama no 48, de 10 de julho de 1995 - Disciplina a exploração florestal na Bacia Amazônica.

- Portaria Ibama n⿳0 113, de 29 de dezembro de 1995 - Dispõe sobre o manejo florestal sustentável, que passa a ser essencial para a permissão de exploração das florestas primitivas e demais formas de vegetação arbórea, que tenha como objetivo principal a obtenção econômica de produtos florestais (Art. $1^{0}$ ). Entende-se por manejo florestal sustentável a administração da floresta para obtenção de benefícios econômicos e sociais, respeitando-se os mecanismos de sustentação do ecossistema objeto de manejo ( $\$$ único).

A execução do manejo somente será permitida através de plano de manejo florestal sustentável - PMFS, de acordo com regulamentação estabelecida pelo Ibama, através de Câmara Técnica a ser instituída pelas suas Superintendências Estaduais SUPES e obedecidos os mesmos princípios gerais e fundamentos técnicos definidos no Art. $2^{\circ}$ do Decreto $\mathrm{n}^{\mathrm{0}} 1.282 / 94$. As SUPES, através de avaliação de sua Câmara Técnica, pode admitir a exploração florestal sem a apresentação do PMFS em propriedades de até 50 hectares $\left(\S 1^{\frac{0}{}}\right)$. Para tanto a Câmara Técnica deve estabelecer normas específicas para apresentação, avaliação e controle $\left(\$ 2^{0}\right)$. A Diretoria de Recursos Naturais Renováveis - DIREN estabelecerá normas para a constituição desta Câmara Técnica $\left(\S 3^{\circ}\right)$. 
- Portaria Ibama nº 29, de 26 de abril de 1996 - Dispõe sobre reposição florestal obrigatória, plano integrado florestal e associação florestal. Fica obrigada à reposição florestal a pessoa física ou juridica que explore, utilize, transforme ou consuma matéria-prima florestal (Art. $1^{\mathrm{O}}$ ). A reposição florestal deve ser efetuada na Unidade da Federação de origem da matéria-prima florestal, mediante o plantio de espécies florestais compatíveis com a atividade desenvolvida, preferencialmente nativas, conduzido com técnicas silviculturais que venham a assegurar uma produção que seja, no mínimo, igual ao volume anual necessário à atividade desenvolvida $\left(\$ 2^{\underline{\underline{o}}}\right)$.

Fica isenta da obrigatoriedade de reposição florestal a pessoa física ou juridica que venha a prover de (Art. $7^{\circ}$ ): matéria-prima proveniente de área submetida a manejo florestal sustentável (inciso I).

- Decreto no 1.282 , de 19 de outubro de 1994 - Regulamenta os arts. 15, 19, 20 e 21 da Lei $n^{0} 4.771 / 65$. A exploração das florestas primitivas da Amazônia e demais formas de vegetação natural somente será permitida sob a forma de manejo florestal sustentável, segundo os principios gerais e fundamentos técnicos estabelecidos neste Decreto (Art. $1^{\underline{0}}$ ). Entende-se por manejo florestal sustentável a administração da floresta para a obtenção de benefícios econômicos e sociais, respeitando-se os mecanismos de sustentação do ecossistema objeto do manejo $\left(\S 1^{\underline{0}}\right)$.

O plano de manejo sustentável das florestas primitivas e demais formas de vegetação natural da Amazônia atenderá aos seguintes princípios gerais e fundamentos técnicos (Art. 2 ${ }^{\circ}$ ): I — Princípios Gerais: a) conservação dos recursos naturais; b) conservação da estrutura da floresta e de suas funções; c) manutenção da diversidade biológica; e d) desenvolvimento socioeconômico da região. Il - Fundamentos técnicos: a) levantamento criterioso dos recursos disponíveis a fim de assegurar a confiabilidade das informações pertinentes; b) caracterização da estrutura e do sítio florestal; c) identificação, análise e controle dos impactos ambientais, atendendo à legislação pertinente; d) viabilidade técnico-econômica e análise das conseqüências sociais; e) procedimentos de exploração florestal que minimizem os danos sobre o ecossistema; f) existência de estoque remanescente do recurso que garanta a produção sustentada da floresta; g) adoção de sistema silvicultural adequado; e h) uso de técnicas apropriadas de plantio, sempre que necessário.

A exploração de recursos florestais na Bacia Amazônica por proprietários, ou legítimo ocupante, de pequeno ou médio imóvel rural, que desenvolva atividades silviculturais, será admitida sem a apresentação de plano de manejo florestal sustentável, observadas exigências, condições e prazos a serem estabelecidos pelo Ibama.

Fica obrigada à reposição florestal a pessoa física ou jurídica que explore, utilize, transforme ou consuma matéria-prima florestal (Art. $9^{\mathbf{0}}$ ). A pessoa física ou jurídica que comprovadamente venha a se prover dos residuos ou da matéria-prima a seguir mencionadas, fica isenta da reposição florestal relativa a esse suprimento: matéria-prima proveniente de manejo florestal sustentável (Inciso I); matéria-prima florestal própria, em benfeitoria dentro da propriedade, na qualidade de proprietário rural e detentor de competente autorização de desmatamento (Inciso II). O Plano Integrado Florestal (PIF) será apresentado ao Ibama por pessoa física ou jurídica que necessite de grande quantidade de matéria-prima florestal (Art. 12). 
- Portaria DEPRN no 52 , de 28 de dezembro de 1998 - Dispõe sobre a exploração seletiva de determinadas espécies vegetais nativas nas áreas cobertas por vegetação primária ou nos estágios médio e avançado de regeneração da Mata Atlântica que poderá ocorrer, desde que observados, entre outros, a elaboração de projetos fundamentados em estudos prévios técnicos-científicos de estoques e garantia de capacidade de manutenção da espécie; e a prévia autorização do órgão estadual competente, cumprindo-se as diretrizes e os critérios por ele estabelecidos, conforme art. $2^{\underline{0}}$ do Decreto Federal $n^{\circ} 750 / 93$ (grifo nosso).

As principais sugestões presentes nesta portaria são: a exploração (de espécies nativas da Mata Atlântica que não possuam regulamentação específica, com exceção daquelas extraídas para o autoconsumo); dependerá de Plano de Manejo, a título experimental e deverá ser aprovado pelo DEPRN. O Plano de Manejo deverá ser elaborado por profissional habilitado e deverá seguir as seguintes diretrizes:

A. plano de manejo deve ser realizado para cada espécie, listada no anexo I desta portaria; outras espécies poderão ser incluídas nesta lista;

B. cadastramento anual do extrator, pessoa física e jurídica, no DEPRN, conforme modelo de documento no anexo II desta portaria;

C. as pessoas físicas e jurídicas deverão entregar anualmente ao DEPRN um Relatório de Produção (além de vários dados do extrator, do responsável pela extração, das propriedades e locais de extração, neste relatório deve ser indicada a quantidade mensal em quilograma de matéria verde extraída por espécie), conforme modelo no anexo III desta portaria;

D. deverão constar no Plano de Manejo o seguinte:

- nome e endereço da propriedade usada para a extração;

- planta planialtimétrica em escala não inferior a $1: 10$ 000, indicando os locais da extração;

- caracterização da espécie a ser manejada (classificação botânica e ecológica);

- uso proposto, para a planta inteira ou partes, se for o caso;

- caracterização da população da espécie vegetal no local de extração;

- descrição da estratégia de manejo, ciclos de corte e acompanhamento;

- Informações sobre garantias da manutenção da espécie, incluindo plantas matrizes, regeneração por sementes ou vegetativa;

- outras informações podem ser solicitadas por e a critério do DEPRN.

C) Comercialização e transporte de plantas medicinais:

- Portaria Normativa IBDF n⿳0 $122-P$, de 19 de março de 1985 - Dispõe sobre o registro no IBDF. A apanha, o transporte, o comércio e a industrialização de plantas medicinais, aromáticas ou tóxicas, nativas dependem de registro de autorização do IBDF e obrigam à reposição com indivíduos da espécie botânica utilizada, atendidas as peculiaridades bioecológicas e ouvidas as respectivas Delegacias (Art. 43). Do pedido de registro devem constar (Art. 44): identidade do responsável, endereço e capacitação técnica; razão social, atividade principal, produto final a ser obtido e previsão econômica. Do pedido de autorização para apanha, transporte, comercialização ou industrialização devem, obrigatoriamente, constar os seguintes dados (Art. 45): a) 
área fisica ou territorial abrangida: localização, extensão e limites, topografia (relevo) e acidentes geográficos, altitude e clima, tipo de vegetação dominante, via de acesso e meios de transporte, modalidade da justa posse ou autorização do proprietário; b) material botânico a ser utilizado: nome vulgar e nome científico; porte (arbóreo, arbustivo, herbáceo); ciclo vegetativo; número médio de espécimens, por hectare; órgão da planta a ser utilizado; substância a ser obtida; peso seco/ha da parte vegetal a ser utilizada.

A utilização de matéria-prima proveniente de plantas medicinais nativas, determina a obrigatoriedade da reposição do material colhido, nas seguintes proporções (Art. 46): 1) plantas herbáceas: $1 \mathrm{~kg}$ de folhas $=4$ mudas; $1 \mathrm{~kg}$ de caule $=8$ mudas; $1 \mathrm{~kg}$ de raiz $=12$ mudas. 2) plantas arbustivas: $3 \mathrm{~kg}$ de folhas $=1$ muda; $1 \mathrm{~kg}$ de casca $=3$ mudas; $1 \mathrm{~kg}$ de lenho $=2$ mudas; $1 \mathrm{~kg}$ de raiz $=4$ mudas. 3) plantas arbóreas: $5 \mathrm{~kg}$ de folhas $=1$ muda; $1 \mathrm{~kg}$ de casca $=2$ mudas; $1 \mathrm{~kg}$ de lenho $=1$ muda; $1 \mathrm{~kg}$ de raiz $=3$ mudas.

As pessoas físicas ou jurídicas que utilizem matéria-prima procedente de exploração de plantas medicinais nativas, e que estejam obrigadas a realizar reposição de matéria-prima segundo as bases estabelecidas no artigo anterior, poderão optar (Art. 47): pela apresentação de projetos de plantio ou replantio (Inciso I); pelo recolhimento, ao IBDF, do valor equivalente ao custo do plantio ou replantio (Inciso II); pela participação em projetos de terceiros, implantado para essa finalidade por empresa especializada (Inciso III). Tais planos e projetos de exploração e de reposição deverão estar assinados por engenheiro agrônomo ou florestal devidamente registrados no CREA.

As pessoas físicas ou empresas de pequeno porte localizadas em áreas rurais, que por contrato de fornecimento de plantas medicinais estiverem vinculadas à empresa industrial produtora-comerciante, ficarão dispensadas de realizar reposição (Art. 48). O IBDF aplicará percentual adequado de seus recursos financeiros para desenvolver novas técnicas de plantio, economicamente viáveis, das espécies vegetais medicinais (Art. 49). Os recursos financeiros provenientes dos recolhimentos de que trata o inciso II do artigo 47, serão integralmente aplicados na respectiva Unidade Federativa, para ( $\$$ único): a) replantio, no mesmo local, de indivíduos da mesma espécie botânica utilizada ou plantio de espécimes em local ecologicamente semelhante àquele de onde as referidas plantas nativas foram retiradas; b) desenvolvimento em FLONAs, EFLEXs e POFOMs, de técnicas de reprodução, multiplicação, plantio e transplantio, economicamente viáveis, das referidas espécies vegetais medicinais nativas, cujas melhores formas de cultivo ainda não tenham sido estabelecidas.

O IBDF através de suas Delegacias, fornecerá guias de transporte, em quantidade relativa à capacidade de produção demonstrada, prevista ou avaliada (Art 50). A exportação de plantas medicinais ou dos princípios ativos, essências e extratos, delas obtidos, só será permitida às firmas registradas no IBDF que, obedecidas as prescrições legais e regulamentares, fornecerá a respectiva guia de transporte (Art. 51). Tratando-se de material científico, a sua exportação estará, obrigatoriamente, sob a responsabilidade imediata de instituição científica oficial ou oficializada, e a autorização do IBDF dependerá de consulta a ser previamente formulada pelo $\mathrm{CNPq}$ (§ único).

- Portaria Normativa IBDF n⿳0 302-P, de 9 de novembro de 1988 - Dispõe sobre registro no IBDF. São obrigadas ao registro no IBDF as pessoas fisicas e jurídicas 
que utilizem, explorem, comercializem, industrializem, sob qualquer forma, espécimes da flora e da fauna silvestre, seus produtos e subprodutos (Art. $1^{\underline{Q}}$ ).

- Portaria Ibama no 732 , de $1^{\circ}$ de abril de 1991 - Estabelece normas para o registro no Ibama, das pessoas físicas e jurídicas que exercem atividades relacionadas com o setor florestal, nas categorias a seguir discriminadas (Art. $1^{\underline{0}}$ ): a) administradora; b) especializada; c) consultoria florestal; d) associação florestal; e) cooperativa florestal (definidas no Art. $2^{\circ}$ ).

- Portaria SEMAN/PR no 139, de 5 de junho de 1992 - Institui a obrigatoriedade de autorização para o transporte de produtos florestais de origem nativa. Institui, a nível nacional, o instrumento de controle 'Autorização para Transporte de Produto Florestal - ATPF', como documento obrigatório para as pessoas físicas ou jurídicas que transportem produtos florestais de origem nativa (Art. $1^{\circ}$ ). Entende-se por produtos florestais aqueles que se encontram no seu estado bruto ou in natura, abaixo relacionados ( $\S$ único): madeira em toras; toretes; postes não imunizados; escoramentos; palanques roliços; dormentes nas fases de extração/fornecimento; mourões ou moirões; achas e lascas; pranchões desdobrados com motoserra; lenha; palmito; xaxim; óleos essenciais.

A ATPF será fornecida pelo Ibama aos detentores de Autorização de Desmate, Exploração, Manejo e Planos de Corte, em número compativel ao volume do desmate/corte autorizado (Art. $2^{\mathrm{o}}$ ).

- Portaria Ibama no 44-N, de 6 de abril de 1993 - Dispõe sobre a Autorização para Transporte de Produto Florestal - ATPF. Além da lista apresentada pela Portaria SEMAN/PR 139/92, considera como produtos florestais (Art. $1^{\circ}, \mathbf{g}^{\mathbf{0}}$ ): as plantas medicinais, bem como as mudas, raizes, bulbos, cipós e folhas de origem nativa, para efeito de transporte com ATPF, da fase de coleta, apanha ou extração. O Regime Especial de Transporte (RET) será autorizado pelo Ibama e seu uso representa a licença obrigatória a ser aposta no corpo de todas as vias das Notas Fiscais (Art. 11). O carimbo padronizado será utilizado para transporte de (Art. 12): plantas medicinais, provenientes de produtor e para exportação (inciso III).

- Portaria Ibama no 83, de 15 de outubro de 1996 - Dispõe sobre a exportação de produtos e subprodutos oriundos da flora brasileira, nativa ou exótica. Regulamenta a exportação de mercadorias, assim entendidas como dos produtos e subprodutos oriundos da flora brasileira, nativa ou exótica (Art. $1^{\mathfrak{9}}$ ).

Levando-se em consideração origem, natureza, espécie, quantidade, qualidade, grau de industrialização e outras, e consoantes à política de preservação e conservação dos recursos naturais renováveis, ficam estabelecidas as seguintes categorias de exportação (Art. 20 ${ }^{\mathrm{o}}$ ): a) Livre: refere-se a mercadoria sem restrição à sua comercialização. Todavia, devem ser observadas as normas gerais e/ou os tratamentos administrativos que orientam sua exportação (Inciso I); b) Limitada: refere-se à mercadoria sujeita à procedimentos especiais ou a contingenciamento, observado, no que couber, as normas gerais e/ou os tratamentos administrativos que orientam a sua exportação (Inciso II); c) Suspensa: refere-se à mercadoria impedida temporariamente de ser exportada (Inciso III); d) Proibida: refere-se à mercadoria cuja saída do território 
nacional é vedada, considerando-se como tal aquela que assim esteja prevista em lei e tratados ou convenção internacional firmado pelo Brasil.

Os interessados em atuar como exportadores de produtos e subprodutos da flora devem obter o Registro de Exportador junto ao Ibama, de acordo com as normas estabelecidas em legislação pertinente (Art. $4^{0}$ ), o qual pode ser negado, suspenso ou cancelado em decorrência de punição pelo cometimento de infração prevista na legislação ambiental vigente ( $\$$ único).

As mercadorias destinadas a feiras e exposições, a estudos técnico-científicos ou à promoção comercial no exterior dependem de autorização prévia do Ibama (Art. $8^{\underline{0}}$ ), e devem respeitar as normas de importação quando do seu retorno ao país ( $\S$ único).

Para a consecução dos objetivos estabelecidos nesta Portaria, fica criado, no âmbito da Diretoria de Recursos Naturais Renováveis - DIREN, o Sistema Nacional de Controle das Exportações de Mercadorias da Flora Brasileira - Siscoex (Art. 11).

Esta portaria relaciona em anexo as mercadorias que têm sua exportação limitada, suspensa ou proibida, em virtude de legislação ou em decorrência de compromissos internacionais assumidos pelo Brasil. 
ANEXO 3 - INSTRUMENTOS DA PESQUISA 
1) Qual o seu nome completo?

2) Qual é o seu endereço para mandar cartas? (Endereço para correspondência)

3) Como este lugar é conhecido? (Endereço residencial)

Registro

Sete Barras

Pariquera-Açu

Juquiá

Eldorado

Iguape

Ilha Comprida

Cananéia

Outros

4) O sr. sempre viveu aqui?

Sim ( ) Não( )

5) De onde o sr. veio?

Vale do Ribeira

Nordeste

Norte

Sul

Centro- oeste

Sudeste

Outros

Sem informação

8) O sr. foi à escola?

SIM

Até que ano?

Primário incomp.

Primário comp.

Ginásio incomp.

Ginásio comp.

Técnico- $1^{\circ}$ grau incomp.

Técnico- $1^{\circ}$ grau comp.

Colegial incomp.

Colegial comp.

Técnico $-2^{\circ}$ grau incomp.

Técnico - $2^{\circ}$ grau comp.

Superior incomp.

Superior comp.

Outros

Sem informação
6) Sexo:

Masculino

Feminino

7) Quantos anos o sr. tem?

\begin{tabular}{|c|c|}
\hline$<20$ & ( \\
\hline $20 \bullet \ldots-\ldots$ & ( \\
\hline $30 \cdot \ldots-\ldots$ & ( \\
\hline 40 •... 50 & ( \\
\hline 50 •-.-- 60 & ( \\
\hline $60 \bullet----70$ & ( \\
\hline $70 \bullet----80$ & ( \\
\hline$>\bullet 80$ & ( \\
\hline
\end{tabular}


9) O sr. mora sozinho?

\section{$\operatorname{SIM} \quad(\quad)$ NÃO ( )}

Quantas pessoas moram com o Sr.?

1 •...- 3
$3 \cdot \ldots-\cdots 5$
$5 \cdot \cdots-.-8$
$>8$

12) Categoria de atividade em relação a extração de plantas medicinais:

Produtor

Extrator

Intermediário

Outros

$\left.\begin{array}{ll}( & ) \\ ( & ) \\ ( & \end{array}\right)$

10) Quantas dessas pessoas que moram com o sr. dependem da venda de plantas medicinais para viver?

nenhum
$1 \cdot \ldots-\cdots 3$
$3 \bullet-\cdots-\ldots$
$5 \bullet-\cdots-.-8$
$>8$
s/inf.

11) Quanto a sua familia ganha por mês? (em salários mínimos)

\begin{tabular}{|c|c|}
\hline$<1$ & ( \\
\hline 1 & ( \\
\hline 2 & ( \\
\hline 3 & ( \\
\hline$>4$ & ( \\
\hline $\begin{array}{l}\text { Sem } \\
\text { informação }\end{array}$ & ( \\
\hline
\end{tabular}

14) O sr. ganha dinheiro com outra atividade?
NÃO
( ) SIM

- Há quanto tempo trabalha na extração de plantas medicinais?

menos de 1 ano

de 1 -..... 3 anos

de 3 -..... 5 anos

de 5 -....- 8 anos

de 8 -...- 10 anos

mais de 10 anos

- Com o quê?

Cultura de chá

Cultura de banana

Cultura de milho

Cultura de arroz

Cultura de mandioca

) Outras culturas

Extração de látex

Extração de palmito

Extração de caxeta

Outros produtos de extração

Prestação de serviços

13) Quanto o sr. extrai, em média, por mês? (toneladas de planta fresca)

\begin{tabular}{|c|c|}
\hline$<1$ & ( \\
\hline $1 \bullet \ldots-2$ & ( \\
\hline $2 \bullet-\cdots--3$ & ( \\
\hline 3 & ( \\
\hline$>\cdot 4$ & ( \\
\hline
\end{tabular}

Outras atividades

Sem informação

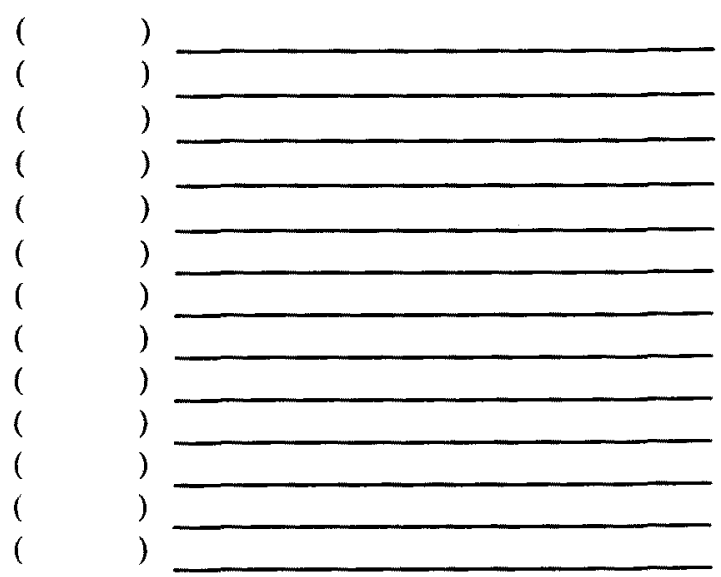

15) O que o sr. acha do trabalho da:

Policia Florestal:

\section{Ibama:}


16) O sr. já ouviu falar da Aepam

NÃO

SIM
É sócio?

SIM

$\mathrm{NĀO}$
17) O que o sr. acha do trabalho da Aepam?

18) O sr. acha que um dia as plantas medicinais podem acabar?

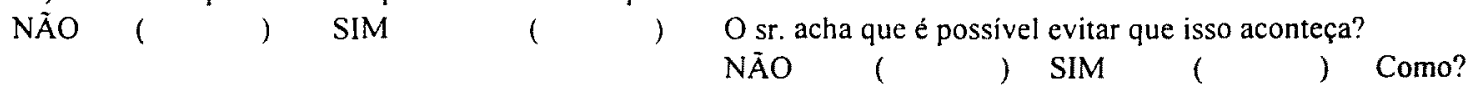


1) Quais são as plantas que o sr. extrai?

NOME DA PLANTA:

2) Desta planta, qual parte o sr. extrai?

$\begin{array}{rrrrrr}\text { casca do caule ( ) } & \text { folha ( ) } & \text { látex ( ) } & \text { parte aérea ( ) } & \text { raiz ( ) } & \text { semente ( ) } \\ \text { caule ( ) } & \text { fruto ( ) } & \text { lenho ( ) } & \text { planta toda ( ) } & \text { ramo ( ) } & \text { seiva ( ) } \\ \text { flor ( ) } & \text { goma ( ) } & \text { óleo ( ) } & \text { resina ( ) } & \text { outros ( ) } & (\text { ) }\end{array}$

3) Como o sr. tira esta parte da planta?

corte de todo o indivíduo ( )

descasca $50 \%$ da planta unilateral ( )

podas periódicas da parte aérea ( )

podas periódicas do ramo ( )

sangrias ( )

recolhimento do chão ( )

outros ( )

sem informação ( )

4) O que o sr. olha na planta para escolher qual vai extrair?

$\begin{array}{rr}\text { altura ( ) } & \text { densidade populacional ( ) } \\ \text { coloração ( ) } & \text { estágio de desenvolvimento ( ) } \\ \text { diâmetro ( ) } & \text { processo de recuperação ( ) } \\ \text { floração ( ) } & \text { parte aérea ( ) } \\ \text { frutificação ( ) } & \text { idade do órgão ( ) } \\ \text { viçosidade ( ) } & \text { nada ( ) } \\ & \text { outros ( ) }\end{array}$

5) A que horas o sr. vai para o mato extrair?
manhã ( )
tarde ( )
noite ( )
qualquer ( )
sem informação ( )

6) Em que mês o sr. a extrai?

Observa época para manejar?

$\begin{array}{rrr}\text { Janeiro ( ) } & \text { Fevereiro ( ) } & \text { Março ( ) } \\ \text { Junho ( ) } & \text { Julho ( ) } & \text { Agosto ( ) } \\ \text { Novembro ( ) } & \text { Dezembro ( ) } & \text { Qualquer ( ) }\end{array}$

7) Onde o sr. a extrai?
Mata Pluvial de encosta ( )
Mata ciliar ( )
Mata inundável ( )
Mata de restinga ( )
Mata secundária ( )

\author{
Brejo (várzea) ( ) \\ Capoeira ( ) \\ Campo ( ) \\ Dunas ( ) \\ Ruderal ( )
}
$\operatorname{SIM}($ ) NÃO ( )
Abril ( ) Maio ( )
Setembro ( ) Outubro ( )


8) O que o sr. olha no lugar que indica que tem a planta? (potencial)

$\begin{array}{rr}\text { copa das árvores ( ) } & \text { espécies indicadoras ( ) } \\ \text { declividade ( ) } & \text { tipo de solo }(\text { ) } \\ \text { umidade local }(\text { ) } & \text { clima local }(\text { ) } \\ \text { altitude }(\text { ) } & \text { outros }(\text { ) }\end{array}$

sem informação ( )

nada ( )

9) Durante quanto tempo o sr. usa o mesmo mato para extração desta planta? anualmente ( )
de 6 em 6 meses ( )
usa continuamente ( )
não observa periodo ( )
outros ( )
sem informação ( )

10) Como o sr. escolhe o lugar onde vai extrair?

11) O sr. costuma extrair novamente da mesma planta? (mesmo individuo ou população)
NÃO ( )
$\operatorname{SIM}()$
anualmente ( )
não observa periodo ( )
de 6 em 6 meses ( )
outros ( )
continuamente ( )
sem informação ( )

De quanto em quanto tempo?

12) Como o sr. carrega a planta?

em feixes sem ensacar $(\quad)$
em feixes ensacado $(\quad)$
em pedaços ensacado $(\quad)$

Outros ( )

sem informação ( )

\section{Observacões:}


1) Como o sr. vende o/a (parte) da planta ?

\section{SECA ( )}

- O sr. faz separação (limpeza, triagem)? Não ( ) Sim ( )

Como é feita?

$\begin{array}{rrr}\text { retirada de bichos ( ) } & \text { retirada de sujeira ( ) } & \text { lavagem da raiz ( ) } \\ \text { outros ( ) } & \text { sem informação ( ) } & \text { lavagem da planta ( ) }\end{array}$

- Como o sr. seca? forno-aberto ( )

$\begin{array}{rr}\text { na sombra }(\text { ) } & \text { outros ( ) } \\ \text { no sol }() & \text { S/inf. }(\text { ) }\end{array}$

forno-fechado ( )

- O sr. tritura?

Não ( ) Sim ( )

Como?

\begin{tabular}{|c|c|c|c|}
\hline pedaços $(10 \mathrm{~cm})$ & ( ) & pedaços $(2 \mathrm{~cm})()$ & sem informação ( ) \\
\hline sara chá $($ sachê/1 cm) & ( ) & outros ( ) & \\
\hline O sr. embala? & Não ( ) & $\operatorname{Sim}()$ & \\
\hline
\end{tabular}

Como?

a granel (sacos $60 \mathrm{Kg})(\mathrm{r}$ tambor hermético ( ) outros ( )

saquinhos de $30 \mathrm{~g}($ ) sacos de $1 \mathrm{Kg} \mathrm{(} \mathrm{)} \mathrm{s/inf.} \mathrm{(} \mathrm{)}$

- O sr. faz controle de qualidade? Não ( ) Sim ( )

Como?

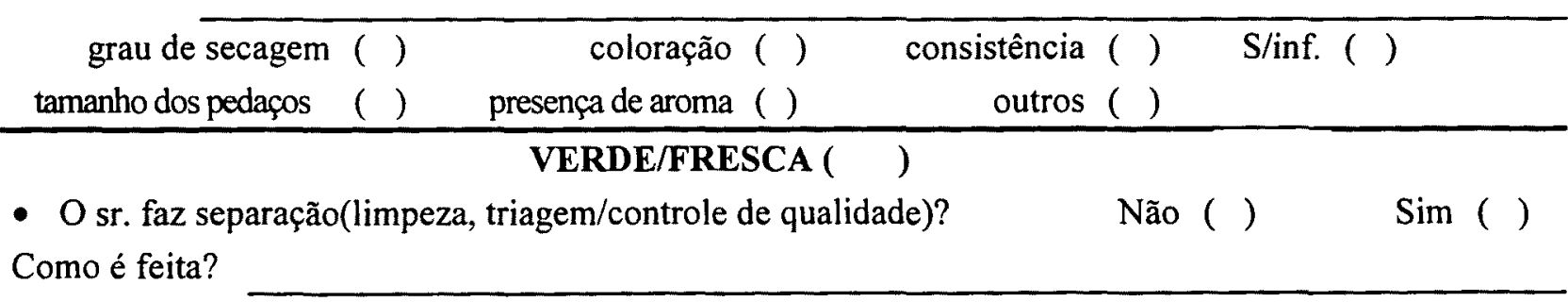

- O sr. embala?

Não ( ) Sim ( )

Como?

3) Qual é o rendimento desta planta? Quanto quebra? [relação entre peso úmido + descartes / peso seco]

$$
\begin{aligned}
& <2 / 1 \quad() \\
& 2 / 1 \cdot---4 / 1 \quad() \\
& \text { 4/1 •-.- 6/1 () } \\
& 6 / 1 \bullet-.-8 / 10 \\
& \text { 8/1 •-..- 10/1 () } \\
& >10 / 1 \quad()
\end{aligned}
$$

4) Por quanto o Sr. vende essa planta? (reais/kilo)

$$
\begin{aligned}
& <10 \\
& 1 \text {-.-- } 50 \\
& 5 \text { •-.- } 10() \\
& 10 \bullet-.-150 \\
& 15 \text { •-.- } 200 \\
& >20 \quad()
\end{aligned}
$$

5) Para quem o Sr. vende esta planta?

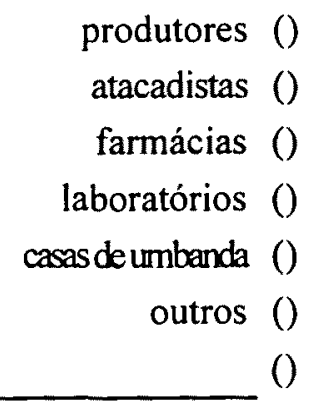

Observações: 
Código:

Nome(s) popular(es):

Família:

Nome científico:

\section{Origem}

Nativa ( )

( )Mata Atiântica
( )Amazônia
( )Cerrado
( )Caatinga
( Campos
( )Outros

\section{( )Regiões Tropicais}

( )Regiões Temperadas

( )Cosmopolita

( )Américas

( )África

( )Ásia

( )Europa

( ) Austrália
Ocorrência

( )Espontânea

( )Cultivada

Hábito

( )Árvore

( )Arbusto

( )Herbácea

( )Epífita

( )Aquática

( )Trepadeira

( )Outros

\section{Substâncias \\ exsudadas}

( )Óleo

( )Goma

( )Látex

( )Mucilagem

( )Resina

( )Seiva

( )Tinta

( )Outros

\section{Habitat}

( )Mata Pluvial de encosta

( )Mata ciliar

( )Mata inundável

( )Restinga

( )Capoeira

( )Capoeirão

( )Capoeira baixa

( )Campo

( )Brejo(várzea)

( )Dunas

( )Outros

\section{Partes Vegetativas}

Aroma:

Sabor:

Obs:

\section{Floração}

Época:

Tipo:

Coloração:

\section{Frutificação}

Época:

Tipo:

Coloração:

Local de coleta:

Coletor(a):

Data da coleta:

Lat/Long:

Obs:

Referência bibliográfica da origem:

Fotógrafo(a):

$\mathrm{N}^{\circ}$ da foto:

$\mathrm{N}^{\circ}$ do slide:

Sistemata (det.):

$N^{\circ}$ de registro no herbário:

Observacões:

Entrevistado: Data 
CóDIGo:

NOME CIENTÍFICO:

FAMÍLIA:

TIPO DE ESTUDO:

FITOQUÍMICO

FARMACOLÓGICO:

PARTE INVESTIGADA:

$\begin{array}{rrrrrr}\text { casca do } & \text { folha } & \text { látex } & \text { semente } & \text { parte área } & \text { resina } \\ \text { caule } & & & & & \\ \text { caule } & \text { fruto } & \text { lenho } & \text { planta toda } & \text { raiz } & \\ \text { flor } & \text { goma } & \text { óleo } & \text { seiva } & \text { ramo } & \end{array}$

\section{PRÍNCIPIO ATIVO:}

Alcalóides

Òleos

Taninos

Outros Essenciais

Glicosideos

$$
\text { Ácidos }
$$

Graxos

Lignanas

Sem

Flavonas Cumarinas

Flavonóides

Informação

\section{COMPLEMENTO:}

AÇÃO FARMACOLÓGICA/TOXIDADE:

OUTRAS APLICAÇÕES

REFERÊNCIA BIBLIOGRÁFICA:

OBS.:

DATA: 
ANEXO 4 - LISTA DAS TABELAS COMPLEMENTARES 
Tabela 1 - Plantas citadas pela amostra de extratores e produtores de plantas medicinais da região do Vale do Ribeira, SP.: nome popular, família e nome científico.

Nome popular
abacate
abre-caminho
abuta 1
abuta 1
abuta 1
abutinha
alecrim-do-campo
alfavaca-brava
alfavaca-brava
alfavacão
altéia
angico
anis
apetaruã
araçá
araticum-de-macaco
arnica
arrueira
artemísia
assa-peixe
azeitona
bálsamo-de-tolu 1
banana-de-babosa
bardana
batata-de-purga

\section{Familia \\ Lauraceae}

Menispermaceae

Menispermaceae

Menispermaceae

Menispermaceae

Asteraceae

Labiatae

Labiatae

Labiatae

Malvaceae

Leguminosae-Mimosoideae

Piperaceae

Myrtaceae

Annonaceae

Asteraceae

Anacardiaceae

Asteraceae

Asteraceae

Euphorbiaceae

Araceae

Asteraceae

Apocynaceae

\section{Nome científico}

Persea americana Mill.

Abuta selloania (Benth.) Eichl.

Cissampelos andromorpha D.C.

Abuta selloana Eichler

Cissampelos andromorpha D.C.

Baccharis sp

Ocimum basilicum $\mathrm{L}$.

Ocimum sp

Ocimum sp

Urena lobata L.

Psidium cattleyanum Sabine.

Rollinia sericea $\mathrm{R}$. E. Fr.

Solidago microglossa D.C.

Schinus terebinthifolius Raddi.

Artemisia cf verlotorum Lamotte

Vernonia sp

Aparisthmium cordatum Poepp.

Philodendron martianum Engl.

Chaptalia sp 


\section{Nome popular}

abacate

batata-de-purga

beico-de-boi

betél

bicuíba

bucuva

caapeba

caferana

cajarana

cambará

cambará

cambará

cambuci

cana-do-breio

canela

cânfora

capa-homem

capa-homem 1

capiá-rosário

capim-cvperus

capitiu

carobinha 1

carobinha 1

carqueja

carqueja

carqueja

carqueja

carrapicho-de-carneiro

caruru-bravo

casearia-silvestris

\section{Família}

Lauraceae

Malpiguiaceae

Leguminosae-Faboideae

Piperaceae

Arecaceae

Myrtaceae

Piperaceae

Meliaceae

Asteraceae

Asteraceae

Verbenaceae

Myrtaceae

Costaceae

Lauraceae

Lauraceae

Apocynaceae

Gramineae

Cyperaceae

Zingiberaceae

Bignoniaceae

Bignoniaceae

Asteraceae

Asteraceae

Asteraceae

Asteraceae

Verbenaceae

Phytoloccaceae

Flacourtiaceae

\section{Nome científico}

Persea americana Mill.

Stigmaphyllon irregulare A. Juss.

Desmodium cf incanum (Sw.) D.C.

Piper cf solmisianum C. D. C.

Virola oleifera (Schott.) A. C. Smith

Potomorphe cf umbellata

Cabralea canjerana (Vell.) Mart.

Vernonia cf polvanthes Less.

Lantana cambara L.

Campomanesia phaea (D.C.) Landrum

Costus spiralis (Jacq.) Roscoe

Cryptocaria saligna Mez.

Cinnamomum camphora $T$. Nees

Peltastes peltatus (Vell.) Woods.

Coix lacryma Jobi L.

Cyperus sp

Renealmia petasites Gagnep.

Jacaranda sp

Jacaranda puberula Cham.

Baccharis cf trimera (Less.) A. P. De Candolle

Pterocaulon sp

Baccharis gaudichaudiana A. P. De Candolle

Baccharis sp

Phytolacea thyrsiflora Fenzl. ex Schimidt

Casearia cf sylvestris Sw. 


Nome popular
abacate
cedro
cedro-branco
centela
chá-de-bugre
chá-do-santo-daime
chá-preto
chapéu-de-couro
cipó-cabeludo
cipó-caboclo
cipó-camarão 1
cipó-camarão 1
cipó-cravo
cipó-cruz
cipó-milomem
copaíba
cordão-de-frade
covatã-branco
covatã-preto
crucia
curare
curcuma-longa
curuanha
curuanha
curucuma-longa
dente-de-leão
doku-dami
embaúba
embaúba
embaúba

\section{Família}

Lauraceae

Meliaceae

Umbelliferae

Apocynaceae

Rubiaceae

Theaceae

Alismataceae

Asteraceae

Dilleniaceae

Dilleniaceae

Quinaceae

Leguminosae-Caesalpinoideae

Labiatae

Sapindaceae

Sapindaceae

Asteraceae

Leguminosae-Faboideae

Zingiberaceae

Leguminosae-Faboideae

Leguminosae-Faboideae

Zingiberaceae

Asteraceae

Cecropiaceae

Cecropiaceae

Cecropiaceae

\section{Nome científico}

Persea americana Mill.

Cedrela fissillis Vell.

Centella asiatica (L.) Urb.

\section{Psychotria sp}

Thea sinensis $\mathrm{L}$.

Echinodorus grandiflorus (Cham. et Schlecht.) Mich.

Mikania cf hirsutissima D.C.

Doliocarpus schottianus Eichl.

Davilla rugosa Poir

Strychnos sp

\section{Copaifera $\mathrm{sp}$}

Leonotis nepetaefolia

Cupania oblongifolia Mart.

Cupania oblongifolia Mart.

Pluchea sagittalis (Less.) Cabrera

Dahlstedtia pinnata (Benth.) Malme

Curcuma sp

Dioclea cf wilsonii Standley

Mucuna altissima D.C.

Curcuma longa

Taraxacum officinalis

\section{Cecropia sp}

Cecropia glaziovi Snethl.

Cecropia pachystachya Trèc. 


\section{Nome popular}

abacate

embaurana

embaurana

erva-baleeira

erva-de-bicho

erva-de-bicho

erva-de-lagarto

erva-de-lagarto

erva-de-passarinho

erva-de-santa-maria

erva-de--santa-maria

erva-de-são-ioão

erva-de-sete-sangrias

erva-tostão

escada-de-macaco

espinheira-santa 1

espinheira-santa 1

espinheira-santa 1

eucalipto 1

fedegoso

fedegoso

gabiroba

gabiroba

garra-do-diabo

gervão-branco

gervão-roxo

ginka-biloba

goiaba

guaçatonga

guaco

\section{Família}

Lauraceae

Cecropiaceae

Euphorbiaceae

Polygonaceae

Polygonaceae

Scrophulariaceae

Loranthaceae

Chenopodiaceae

Chenopodiaceae

Asteraceae

Lythraceae

Amaranthaceae

Leguminosae-Caesalpinoideae

Cactaceae

Leguminosae-Caesalpinoideae

Moraceae

Myrtaceae

Leguminosae-Caesalpinoideae

Leguminosae-Caesalpinoideae

Myrtaceae

Myrtaceae

Leguminosae-Mimosoideae

Euphorbiaceae

Verbenaceae

Myrtaceae

Flacourtiaceae

Asteraceae

\section{Nome científico}

Persea americana Mill

Porouma bicolor Mart.

Aparisthmium cordatum Poepp.

Polvgonum cf pontudo

Polygonum hydropiperoides Michx.

Scoparia dulcis $\mathrm{L}$.

Struthantus concinnus Mart.

Chenopodium ambrosioides $\mathrm{L}$.

Chenopodium cf ambrosioides $\mathrm{L}$.

Ageratum conyzoides $\mathrm{L}$.

Cuphea cartaginensis (Jacq. ) Macbr.

Cyathula cf prostata Blume

Bauhinia cf smilacina Steud.

Zollernia ilicifolia (Brongn.) Vog.

Sorocea bonplandii (Baill. ) W. C. Burguer

Eucaliptus sp

Senna sp

Senna occidentalis (L.) Link

Campomanesia sp

Campomanesia xanthocarpa Berg.

Croton lundianus (F. Driedrichs) Muell. Arg. Stachytarpheta cavenensis Cham..

Psidium guajava $\mathrm{L}$.

Casearia sylvestris $\mathrm{Sw}$.

Mikania sp 


\begin{tabular}{|c|c|c|}
\hline $\begin{array}{l}\text { Nome popular } \\
\text { abacate }\end{array}$ & $\begin{array}{l}\text { Família } \\
\text { Lauraceae }\end{array}$ & $\begin{array}{l}\text { Nome científico } \\
\text { Persea americana Mill. }\end{array}$ \\
\hline guaco & Ranunculaceae & Clematis dioica var. brasiliana (D.C.) Eichler \\
\hline guanandi & Guttiferae & Callophyllum brasilienses Camb. \\
\hline guanchuma & Malvaceae & Sida $\mathrm{sp}$ \\
\hline guiné & Phytoloccaceae & Petiveria alliacea $\mathrm{L}$. \\
\hline inhamutitana & Iridaceae & Eleutherine bulbosa (Mill.) Urb. \\
\hline ipê-amarelo & Bignoniaceae & Tabebuia sp \\
\hline ipê-roxo & Bignoniaceae & Tabebuia cf heptaphvlla (Vell.) Toledo \\
\hline ipê-verde & Bignoniaceae & Tabebuia sp \\
\hline ipeca-branca & Rubiaceae & Psychotria sp \\
\hline ipeca-branca & Smilacaceae & Smilax sp \\
\hline ipecacuanha & Rubiaceae & Psychotria sp \\
\hline jaborandi 1 & Asteraceae & Baccharis cassinefolia D.C. \\
\hline iaboticaba-do-mato & Meliaceae & Cabralea canjerana (Vell.) Mart. \\
\hline jambo & Myrtaceae & Syzygium jambos (L.) \\
\hline iambolão-nativo & Myrtaceae & Syzygium jambos (L.) \\
\hline japecanga & Smilacaceae & Smilax sp \\
\hline jatobá & Leguminosae-Caesalpinoideae & Hymenaea courbaril L. var. - altissima (Ducke) Lee \& Lang. \\
\hline iequitibá-branco & Lauraceae & Cariniana estrellensis (Raddi) Kuntze \\
\hline iequitibá-rosa & Lauraceae & Cariniana sp \\
\hline juá & Solanaceae & Solanum sp \\
\hline iurubeba & Solanaceae & \\
\hline \multicolumn{3}{|l|}{ lingua-de-vaca } \\
\hline mamica-de-porca & Rutaceae & Zanthoxyllum rhoifolium Lam. \\
\hline mamona & Euphorbiaceae & Ricinus communis $\mathrm{L}$. \\
\hline manacá & Solanaceae & \\
\hline maracuiá 1 & Passifloraceae & Passiflora alata Dryand. \\
\hline maracuiá 1 & Passifloraceae & Passiflora edulis Sims \\
\hline marcela 1 & Asteraceae & Gnaphalum cf purpureum $\mathrm{L}$. \\
\hline melão-de-são-caetano & Cucurbitaceae & Momordica cf charantia L. \\
\hline
\end{tabular}




\section{Nome popular}

abacate

melão-de-são-caetano

miconia 1

miconia 1

milomem

mulungu

napoleão

napoleão

niuva

olho-de-boi

palma-cristi

parietária

parietária

pariparoba

pariparoba

pata-de-vaca

pau-d'alho

pente-de-macaco

peroba

picão-branco

picão-preto

poaia-branca

quebra-pedra 1

quebra-pedra 1

quebra-pedra 1

quina-branca

quina-branca

rubi

salssaparrilha 1

salssaparrilha 1

\section{Família}

Lauraceae

Cucurbitaceae

Melastomataceae

Melastomataceae

Aristolochiaceae

Leguminosae-Faboideae

Zingiberaceae

Zingiberaceae

Lauraceae

Myrtaceae

Piperaceae

Urticaceae

Piperaceae

Piperaceae

Leguminosae-Caesalpinoideae

Phytoloccaceae

Cucurbitaceae

Apocynaceae

Asteraceae

Asteraceae

Commelinaceae

Euphorbiaceae

Euphorbiaceae

Euphorbiaceae

Rubiaceae

Solanaceae

Labiatae

Smilacaceae

Smilacaceae

\section{Nome científico}

Persea americana Mill.

Momordica charantia L.

Clidemia hirta D. Don

Leandra dasytricha Cogn.

Aristolochia sp

Erythrina sp

Hedvchium coronarium Koenig.

Myrcia sp

Phenax sonneratii (Soneratii) Wedd.

Potomorphe umbellata (L.) Miq.

Piper cernuum Vellozo

Bauhinia sp

Aspidosperma polyneuron Muel. Arg.

Bidens pilosa $\mathrm{L}$.

Borreria ocymifolia (Roem \& Schult) Bacigalupo \& Cabral

Phyllanthus niruri L.

Phyllanthus urinaria $\mathrm{L}$.

Phyllanthus tenelus Roxb.

Psychotria cf birotula L. B. Sm. \& Downs

Solanum inaequale Vell.

Leonurus leonots

Smilax fluminensis Steud.

Smilax cf subsessiliflora Duhamel 


Nome popular
abacate
salssaparrilha 1
salssaparrilha 1
são-simão
Sapé
sassafrás 1
sassafrás 1
Sene
Suinã
Taiuia
tarumã
tauiá
timbó-cipó
trapoeraba
trombeteira
trombeteira
unha-de-gato
urtiga
urtiga 1
urtiga 1
urucurana
urucurana
vassourinha
zedoária

Família

Lauraceae

Smilacaceae

Smilacaceae

Gramineae

Lauraceae

Lauraceae

Leguminosae-Caesalpinoideae

\section{Cucurbitaceae}

Euphorbiaceae

Commelinaceae

Solanaceae

Solanaceae

Leguminosae-Mimosoideae

Leguminosae-Faboideae

Urticaceae

Euphorbiaceae

Scrophulariaceae

Zingiberaceae

\section{Nome científico}

Persea americana Mill.

Smilax elastica Griseb.

Smilax sp

Ocotea dispersa (Nees.) Mez.

Ocotea cf odorifera (Vell.) Rohwer

Senna multijuga (Rich.) Irwin \& Barneby

\section{Cayaponia sp}

Vitex polvgama Cham.

\section{Commelina $\mathrm{sp}$}

Brugmansia suaveolens (HBK ex Willd) Bercht. \& Presl.

Brugmansia cf suaveolens Bercht. \& Press.

Acacia paniculata Willd.

Erythrina speciosa Andr.

Urera nitida (Vell.) Brack

Hyeronima alchorneoides Allem.

Scoparia dulcis L.

Curcuma zedoaria 
Tabela 2 - Plantas citadas pela amostra de extratores e produtores de plantas medicinais da região do Vale do Ribeira, SP.: nome científico, família e nome popular.

\section{Nome cientifico}

\section{Familia}

Leguminosae-Mimosoideae

Piperaceae

Apocynaceae

Arecaceae

Asteraceae

Verbenaceae

Apocynaceae

\section{Cactaceae}

Leguminosae-Mimosoideae

\section{Solanaceae}

Solanaceae

\section{Nome popular}

abre-caminho

angico

anis

apetaruã

azeitona

batata-de-purga

bicuíba

caferana

cambará

capa-homem

carrapicho-de-carneiro

cedro

chá-de-bugre

cipó-caboclo

cipó-cravo

cipó-milomem

doku-dami

erva-baleeira

erva-de-lagarto

espinheira-santa 1

garra-do-diabo

ginka-biloba

jurubeba

línqua-de-vaca

manacá 
Nome científico

Abuta selloana Eichler Abuta selloania (Benth.) Eichl.

Acacia paniculata Willd.

Ageratum conyzoides $\mathrm{L}$.

Aparisthmium cordatum Poepp.

Aparisthmium cordatum Poepp.

Aristolochia sp

Artemisia cf verlotorum Lamotte

Aspidosperma polyneuron Muel.

Baccharis cassinefolia D.C.

Baccharis cf trimera (Less.) A. P. Asteraceae

Baccharis gaudichaudiana A. P.

Baccharis sp

Baccharis sp

Bauhinia cf smilacina Steud.

Bauhinia sp

\section{Família}

Zingiberaceae

Lauraceae

\section{Piperaceae}

Phytoloccaceae

Cucurbitaceae

Asteraceae

Gramineae

Menispermaceae

Menispermaceae

Leguminosae-Mimosoideae

Asteraceae

Euphorbiaceae

Euphorbiaceae

Aristolochiaceae

Asteraceae

Apocynaceae

Asteraceae

Asteraceae

Leguminosae-Caesalpinoideae

Leguminosae-Caesalpinoideae

\section{Nome popular}

napoleão

niuva

palma-cristi

parietária

pau-d'alho

pente-de-macaco

picão-branco

são-simão

Sapé

Suinã

tauiá

timbó-cipó

urtiga

urucurana

abuta 1

abuta 1

unha-de-gato

erva-de-são-ioão

bálsamo-de-tolu 1

embaurana

milomem 1

artemísia

peroba

jaborandi 1

carqueja

carqueja

alecrim-do-campo

carqueja

escada-de-macaco

pata-de-vaca 


\section{Nome científico}

Bidens pilosa $\mathrm{L}$.

Borreria ocymifolia (Roem \&

Brugmansia cf suaveolens Bercht.

Brugmansia suaveolens (HBK ex

Cabralea canierana (Vell.) Mart.

Cabralea canjerana (Vell.) Mart.

Callophyllum brasilienses Camb.

Campomanesia phaea (D.C.)

Campomanesia sp

Campomanesia xanthocarpa Berg.

Cariniana estrellensis (Raddi)

\section{Cariniana sp}

Casearia cf sylvestris Sw.

Casearia sylvestris Sw.

Cayaponia sp

Cecropia glaziovi Snethl.

Cecropia pachystachya Trèc.

Cecropia sp

Cedrela fissillis Vell.

Centella asiatica (L.) Urb.

Chaptalia sp

Chenopodium ambrosioides $\mathrm{L}$.

Chenopodium cf ambrosioides L.

Cinnamomum camphora T. Nees

Cissampelos andromorpha D.C.

Cissampelos andromorpha D.C.

Clematis dioica var. brasiliana

Clidemia hirta D. Don

Coix lacryma Jobi L.

Commelina $\mathrm{sp}$

\section{Família}

Asteraceae

Commelinaceae

Solanaceae

Solanaceae

Meliaceae

Meliaceae

Guttiferae

Myrtaceae

Myrtaceae

Myrtaceae

Lauraceae

Lauraceae

Flacourtiaceae

Flacourtiaceae

Cucurbitaceae

Cecropiaceae

Cecropiaceae

Cecropiaceae

Meliaceae

Umbelliferae

Asteraceae

Chenopodiaceae

Chenopodiaceae

Lauraceae

Menispermaceae

Menispermaceae

Ranunculaceae

Melastomataceae

Gramineae

Commelinaceae

\section{Nome popular}

picão-preto

poaia-branca

trombeteira

trombeteira

cajarana

iaboticaba-do-mato

guanandi

cambuci

gabiroba

gabiroba

iequitibá-branco

iequitibá-rosa

casearia-silvestris

guaçatonga

Taiuia

embaúba

embaúba

embaúba

cedro-branco

centela

bardana

erva-de-santa-maria

erva-de-santa-maria

\section{cânfora}

abuta 1

abutinha

guaco

miconia 1

capiá-rosário

trapoeraba 


\section{Nome científico}

Copaifera $\mathrm{sp}$

Costus spiralis (Jacq.) Roscoe

Croton lundianus (F. Driedrichs)

Cryptocaria saligna Mez.

Cupania oblongifolia Mart.

Cupania oblongifolia Mart.

Cuphea cartaginensis (Jacq. )

Curcuma longa

Curcuma sp

Curcuma zedoaria

Cyathula cf prostata Blume

Cyperus sp

Dahlstedtia pinnata (Benth.)

Davilla rugosa Poir

Desmodium cf incanum (Sw.) D.C.

Dioclea cf wilsonii Standley

Doliocarpus schottianus Eichl.

Echinodorus grandiflorus (Cham.

Eleutherine bulbosa (Mill.) Urb.

Erythrina sp

Erythrina speciosa Andr.

Eucaliptus sp

Gnaphalum cf purpureum L.

Hedychium coronarium Koenig.

Hveronima alchorneoides Allem.

Hvmenaea courbaril L. var. -

Jacaranda puberula Cham.

Jacaranda sp

Lantana cambara $\mathrm{L}$.

Leandra dasytricha Cogn.

\section{Família}

Leguminosae-Caesalpinoideae

Costaceae

Euphorbiaceae

Lauraceae

Sapindaceae

Sapindaceae

Lythraceae

Zingiberaceae

Zingiberaceae

Zingiberaceae

Amaranthaceae

Cyperaceae

Leguminosae-Faboideae

Dilleniaceae

Lequminosae-Faboideae

Leguminosae-Faboideae

Dilleniaceae

Alismataceae

Iridaceae

Lequminosae-Faboideae

Leguminosae-Faboideae

Myrtaceae

Asteraceae

Zingiberaceae

Euphorbiaceae

Leguminosae-Caesalpinoideae

Bignoniaceae

Bignoniaceae

Verbenaceae

Melastomataceae

\section{Nome popular}

copaiba

cana-do-breio

gervão-branco

canela

covatã-branco

covatã-preto

erva-de-sete-sangrias

curucuma-longa

curcuma-longa

zedoária

erva-tostão

capim-cyperus

curare

cipó-camarão 1

beico-de-boi

curuanha

cipó-camarão 1

chapéu-de-couro

inhamutitana

mulungu

urtiga 1

eucalipto 1

marcela 1

napoleão

urucurana

jatobá

carobinha 1

carobinha 1

cambará

miconia 1 


\section{Nome científico}

Leonotis nepetaefolia

Leonurus leonots

Mikania cf hirsutissima D.C.

Mikania sp

Momordica cf charantia L.

Momordica charantia L.

Mucuna altissima D.C.

Myrcia sp

Ocimum basilicum $\mathrm{L}$.

Ocimum sp

Ocimum sp

Ocotea cf odorifera (Vell.) Rohwer

Ocotea dispersa (Nees.) Mez.

Passiflora alata Dryand.

Passiflora edulis Sims

Peltastes peltatus (Vell.) Woods.

Petiveria alliacea $\mathrm{L}$.

Phenax sonneratii (Soneratii)

Philodendron martianum Engl.

Phyllanthus niruri $\mathrm{L}$.

Phyllanthus tenelus Roxb.

Phyllanthus urinaria $\mathrm{L}$.

Phytolacea thyrsiflora Fenzl. ex

Piper cernuum Vellozo

Piper cf solmisianum C. D. C.

Pluchea sagittalis (Less.) Cabrera

Polygonum cf pontudo

Polygonum hydropiperoides

Porouma bicolor Mart.

Potomorphe cf umbellata

\section{Familia}

Labiatae

Labiatae

Asteraceae

Asteraceae

Cucurbitaceae

Cucurbitaceae

Leguminosae-Faboideae

Myrtaceae

Labiatae

Labiatae

Labiatae

Lauraceae

Lauraceae

Passifloraceae

Passifloraceae

Apocynaceae

Phytoloccaceae

Urticaceae

Araceae

Euphorbiaceae

Euphorbiaceae

Euphorbiaceae

Phytoloccaceae

Piperaceae

Piperaceae

Asteraceae

Polygonaceae

Polygonaceae

Cecropiaceae

Piperaceae

\section{Nome popular}

cordão-de-frade

rubi

cipó-cabeludo

guaco

melão-de-são-caetano

melão-de-são-caetano

curuanha

olho-de-boi

alfavaca-brava

alfavaca-brava

alfavacão

sassafrás 1

sassafrás 1

maracuiá 1

maracuiá 1

capa-homem 1

guiné

parietária

banana-de-babosa

quebra-pedra 1

quebra-pedra 1

quebra-pedra 1

caruru-bravo

pariparoba

betél

crucia

erva-de-bicho

erva-de-bicho

embaurana

caapeba 
Nome científico

Potomorphe umbellata (L.) Miq.

Psidium cattleyanum Sabine.

Psidium guajava L.

Psychotria cf birotula L. B. Sm. \&

Psychotria sp

Psychotria sp

Psychotria sp

Pterocaulon sp

Renealmia petasites Gagnep.

Ricinus communis $\mathrm{L}$.

Rollinia sericea R. E. Fr.

Schinus terebinthifolius Raddi.

Scoparia dulcis L.

Scoparia dulcis L.

Senna multijuga (Rich.) Irwin \&

Senna occidentalis (L.) Link

Senna sp

Sida sp

Smilax cf subsessiliflora Duhamel

Smilax elastica Griseb.

Smilax fluminensis Steud.

Smilax sp

Smilax sp

Smilax sp

Solanum inaequale Vell.

Solanum sp

Solidago microglossa D.C.

Sorocea bonplandii (Baill. ) W. C. Moraceae

Stachytarpheta cayenensis Cham.. Verbenaceae

Stigmaphyllon irregulare A. Juss. Malpiguiaceae

\section{Nome popular}

pariparoba

araçá

goiaba

auina-branca

chá-do-santo-daime

ipeca-branca

ipecacuanha

carqueja

capitiu

mamona

araticum-de-macaco

arrueira

erva-de-lagarto

vassourinha

Sene

fedegoso

fedegoso

guanchuma

salssaparrilha 1

salssaparrilha 1

salssaparrilha 1

ipeca-branca

japecanga

salssaparrilha 1

auina-branca

juá

arnica

espinheira-santa 1

gervão-roxo

batata-de-purga 


$\begin{array}{lll}\text { Nome cientifico } & \text { Família } & \text { Nome popular } \\ \text { Struthantus concinnus } \text { Mart. } & \text { Loranthaceae } & \text { erva-de-passarinho } \\ \text { Strychnos } \text { sp } & \text { Quinaceae } & \text { cipó-cruz } \\ \text { Syzygium jambos } \text { (L.) } & \text { Myrtaceae } & \text { iambo } \\ \text { Syzygium } \text { iambos } \text { (L.) } & \text { Myrtaceae } & \text { iambolão-nativo } \\ \text { Tabebuia } \text { cf heptaphylla } \text { (Vell.) } & \text { Bignoniaceae } & \text { ipê-roxo } \\ \text { Tabebuia } \text { sp } & \text { Bignoniaceae } & \text { ipê-amarelo } \\ \text { Tabebuia } \text { sp } & \text { Bignoniaceae } & \text { ipê-verde } \\ \text { Taraxacum officinalis } & \text { Asteraceae } & \text { dente-de-leão } \\ \text { Thea sinensis } \text { L. } & \text { Theaceae } & \text { chá-preto } \\ \text { Urena lobata } \text { L. } & \text { Malvaceae } & \text { altéia } \\ \text { Urera nitida } \text { (Vell.) Brack } & \text { Urticaceae } & \text { urtiga 1 } \\ \text { Vernonia } \text { cf polyanthes Less. } & \text { Asteraceae } & \text { cambará } \\ \text { Vernonia } \text { sp } & \text { Asteraceae } & \text { assa-peixe } \\ \text { Virola oleifera } \text { (Schott.) A. C. } & \text { Myrtaceae } & \text { bucuva } \\ \text { Vitex polygama } \text { Cham. } & \text { Euphorbiaceae } & \text { tarumã } \\ \text { Zanthoxyllum } \text { rhoifolium } \text { Lam. } & \text { Rutaceae } & \text { mamica-de-porca } \\ \text { Zollernia } \text { ilicifolia } \text { (Brongn.) Vog. } & \text { Leguminosae-Caesalpinoideae } & \text { espinheira-santa } 1\end{array}$


Tabela 3 - Plantas citadas pela amostra de extratores e produtores de plantas medicinais da região do Vale do Ribeira, SP.: familia, nome popular e nome científico.

\section{Família}

Alismataceae

Amaranthaceae

Anacardiaceae

Annonaceae

Apocynaceae

Apocynaceae

Apocynaceae
Nome popular

abre-caminho

anis

azeitona

caferana

capa-homem

cedro

cipó-caboclo

cipó-cravo

cipó-milomem

doku-dami

erva-baleeira

erva-de-lagarto

ginka-biloba

língua-de-vaca

palma-cristi

são-simão

Suinã

tauiá

timbó-cipó

urtiga

\section{urucurana}

chapéu-de-couro

erva-tostão

arrueira

araticum-de-macaco

batata-de-purga

capa-homem 1

chá-de-bugre

\section{Nome científico}

Echinodorus grandiflorus (Cham. et Schlecht.) Mich.

Cyathula cf prostata Blume

Schinus terebinthifolius Raddi.

Rollinia sericea $\mathrm{R}$. E. Fr.

Peltastes peltatus (Vell.) Woods. 


\section{Familia}

Apocynaceae

Araceae

Arecaceae

Aristolochiaceae

Asteraceae

Asteraceae

Asteraceae

Asteraceae

Asteraceae

Asteraceae

Asteraceae

Asteraceae

Asteraceae

Asteraceae

Asteraceae

Asteraceae

Asteraceae

Asteraceae

Asteraceae

Asteraceae

Asteraceae

Asteraceae

Asteraceae

Asteraceae

Bignoniaceae

Bignoniaceae

Bignoniaceae

Bignoniaceae

Bignoniaceae

Cactaceae

\section{Nome popular}

peroba

banana-de-babosa

bicuiba

milomem 1

alecrim-do-campo

arnica

artemísia

assa-peixe

bardana

cambará

cambará

carqueja

carqueja

carqueja

carqueja

cipó-cabeludo

crucia

dente-de-leão

erva-de-são-ioão

guaco

jaborandi 1

marcela 1

picão-branco

picão-preto

carobinha 1

carobinha 1

ipê-amarelo

ipê-roxo

ipê-verde

espinheira-santa 1

\section{Nome científico}

Aspidosperma polyneuron Muel. Arg.

Philodendron martianum Engl.

Aristolochia sp

Baccharis sp

Solidago microglossa D.C.

Artemisia cf verlotorum Lamotte

Vernonia sp

Chaptalia sp

Vernonia cf polyanthes Less.

Baccharis cf trimera (Less.) A. P. De Candolle

Pterocaulon sp

Baccharis gaudichaudiana A. P. De Candolle

Baccharis sp

Mikania cf hirsutissima D.C.

Pluchea sagittalis (Less.) Cabrera

Taraxacum officinalis

Ageratum conyzoides L.

Mikania sp

Baccharis cassinefolia D.C.

Gnaphalum cf purpureum L.

Bidens pilosa $\mathrm{L}$.

Jacaranda $\mathrm{sp}$

Jacaranda puberula Cham.

Tabebuia sp

Tabebuia cf heptaphylla (Vell.) Toledo

Tabebuia sp 


\section{Família}

Cecropiaceae

Cecropiaceae

Cecropiaceae

Cecropiaceae

Chenopodiaceae

Chenopodiaceae

Commelinaceae

Commelinaceae

Costaceae

Cucurbitaceae

Cucurbitaceae

Cucurbitaceae

Cucurbitaceae

Cyperaceae

Dilleniaceae

Dilleniaceae

Euphorbiaceae

Euphorbiaceae

Euphorbiaceae

Euphorbiaceae

Euphorbiaceae

Euphorbiaceae

Euphorbiaceae

Euphorbiaceae

Euphorbiaceae

Flacourtiaceae

Flacourtiaceae

Gramineae

Gramineae

Guttiferae

\section{Nome popular}

embaúba

embaúba

embaúba

embaurana

erva-de-santa-maria

erva-de-santa-maria

poaia-branca

trapoeraba

cana-do-breio

melão-de-são-caetano

melão-de-são-caetano

pente-de-macaco

Taiuia

capim-cyperus

cipó-camarão 1

cipó-camarão 1

bálsamo-de-tolu 1

embaurana

gervão-branco

mamona

quebra-pedra 1

auebra-pedra 1

quebra-pedra 1

tarumã

urucurana

casearia-silvestris

guaçatonga

capiá-rosário

Sapé

guanandi
Nome científico

Cecropia sp

Cecropia glaziovi Snethl.

Cecropia pachystachya Trèc.

Porouma bicolor Mart.

Chenopodium ambrosioides $\mathrm{L}$.

Chenopodium cf ambrosioides L.

Borreria ocymifolia (Roem \& Schult) Bacigalupo \& Cabral

Commelina sp

Costus spiralis (Jacq.) Roscoe

Momordica cf charantia L.

Momordica charantia $\mathrm{L}$.

Cayaponia sp

Cyperus sp

Doliocarpus schottianus Eichl.

Davilla rugosa Poir

Aparisthmium cordatum Poepp.

Aparisthmium cordatum Poepp.

Croton lundianus (F. Driedrichs) Muell. Arg.

Ricinus communis $\mathrm{L}$.

Phyllanthus niruri $\mathrm{L}$.

Phyllanthus urinaria $\mathrm{L}$.

Phyllanthus tenelus Roxb.

Vitex polygama Cham.

Hyeronima alchorneoides Allem.

Casearia cf sylvestris Sw.

Casearia sylvestris Sw.

Coix lacryma Jobi L.

Callophyllum brasilienses Camb. 


\section{Familia}

Iridaceae

Labiatae

Labiatae

Labiatae

Labiatae

Labiatae

Lauraceae

Lauraceae

Lauraceae

Lauraceae

Lauraceae

Lauraceae

Lauraceae

Leguminosae-Caesalpinoideae

Leguminosae-Caesalpinoideae

Leguminosae-Caesalpinoideae

Leguminosae-Caesalpinoideae

Leguminosae-Caesalpinoideae

Leguminosae-Caesalpinoideae

Leguminosae-Caesalpinoideae

Leguminosae-Caesalpinoideae

Leguminosae-Faboideae

Leguminosae-Faboideae

Leguminosae-Faboideae

Leguminosae-Faboideae

Leguminosae-Faboideae

Leguminosae-Faboideae

Leguminosae-Mimosoideae

Leguminosae-Mimosoideae

Leguminosae-Mimosoideae

\section{Nome popular}

inhamutitana

alfavaca-brava

alfavaca-brava

alfavacão

cordão-de-frade

rubi

canela

cânfora

iequitibá-branco

iequitibá-rosa

niuva

sassafrás 1

sassafrás 1

copaíba

escada-de-macaco

espinheira-santa 1

fedegoso

fedegoso

jatobá

pata-de-vaca

Sene

beico-de-boi

curare

curuanha

curuanha

mulungu

urtiga 1

angico

garra-do-diabo

unha-de-gato

\section{Nome científico}

Eleutherine bulbosa (Mill.) Urb.

Ocimum basilicum L.

\section{Ocimum sp}

Ocimum $\mathrm{sp}$

Leonotis nepetaefolia

Leonurus leonots

Cryptocaria saligna Mez.

Cinnamomum camphora $\mathrm{T}$. Nees

Cariniana estrellensis (Raddi) Kuntze

Cariniana $\mathrm{sp}$

Ocotea dispersa (Nees.) Mez.

Ocotea cf odorifera (Vell.) Rohwer

Copaifera sp

Bauhinia cf smilacina Steud.

Zollernia ilicifolia (Brongn.) Vog.

Senna sp

Senna occidentalis (L.) Link

Hymenaea courbaril L. var. - altissima (Ducke) Lee \& Lang.

Bauhinia sp

Senna multijuga (Rich.) Irwin \& Barneby

Desmodium cf incanum (Sw.) D.C.

Dahlstedtia pinnata (Benth.) Malme

Dioclea cf wilsonii Standley

Mucuna altissima D.C.

Erythrina sp

Erythrina speciosa Andr.

Acacia paniculata Willd. 


\section{Família}

Loranthaceae

Lythraceae

Malpiguiaceae

Malvaceae

Malvaceae

Melastomataceae

Melastomataceae

Meliaceae

Meliaceae

Meliaceae

Menispermaceae

Menispermaceae

Menispermaceae

Menispermaceae

Moraceae

Myrtaceae

Myrtaceae

Myrtaceae

Myrtaceae

Myrtaceae

Myrtaceae

Myrtaceae

Myrtaceae

Myrtaceae

Myrtaceae

Passifloraceae

Passifloraceae

Phytoloccaceae

Phytoloccaceae

Phytoloccaceae

\section{Nome popular}

erva-de-passarinho

erva-de-sete-sangrias

batata-de-purga

altéia

guanchuma

miconia 1

miconia 1

cajarana

cedro-branco

iaboticaba-do-mato

abuta 1

abuta 1

abuta 1

abutinha

espinheira-santa 1

araçá

bucuva

cambuci

eucalipto 1

gabiroba

gabiroba

goiaba

jambo

iambolão-nativo

olho-de-boi

maracujá 1

maracuiá 1

caruru-bravo

guiné

pau-d'alho

\section{Nome científico}

Struthantus concinnus Mart.

Cuphea cartaginensis (Jacq. ) Macbr.

Stigmaphyllon irregulare A. Juss.

Urena lobata L.

Sida sp

Clidemia hirta D. Don

Leandra dasytricha Cogn.

Cabralea canjerana (Vell.) Mart.

Cedrela fissillis Vell.

Cabralea canjerana (Vell.) Mart.

Abuta selloania (Benth.) Eichl.

Cissampelos andromorpha D.C.

Abuta selloana Eichler

Cissampelos andromorpha D.C.

Sorocea bonplandii (Baill.) W. C. Burguer

Psidium cattleyanum Sabine.

Virola oleifera (Schott.) A. C. Smith

Campomanesia phaea (D.C.) Landrum

Eucaliptus sp

Campomanesia sp

Campomanesia xanthocarpa Berg.

Psidium guajava $\mathrm{L}$.

Syzygium iambos (L.)

Syzygium jambos (L.)

\section{Myrcia sp}

Passiflora alata Dryand.

Passiflora edulis Sims

Phytolacea thyrsiflora Fenzl. ex Schimidt

Petiveria alliacea $\mathrm{L}$. 


\section{Família}

Piperaceae

Piperaceae

Piperaceae

Piperaceae

Piperaceae

Piperaceae

Polygonaceae

Polygonaceae

Quinaceae

Ranunculaceae

Rubiaceae

Rubiaceae

Rubiaceae

Rubiaceae

Rutaceae

Sapindaceae

Sapindaceae

Scrophulariaceae

Scrophulariaceae

Smilacaceae

Smilacaceae

Smilacaceae

Smilacaceae

Smilacaceae

Smilacaceae

Solanaceae

Solanaceae

Solanaceae

Solanaceae

Solanaceae

\section{Nome popular}

apetaruã

betél

caapeba

parietária

pariparoba

pariparoba

erva-de-bicho

erva-de-bicho

cipó-cruz

guaco

chá-do-santo-daime

ipeca-branca

ipecacuanha

quina-branca

mamica-de-porca

covatã-branco

covatã-preto

erva-de-lagarto

vassourinha

ipeca-branca

japecanga

salssaparrilha 1

salssaparrilha 1

salssaparrilha 1

salssaparrilha 1

juá

jurubeba

manacá

quina-branca

trombeteira

\section{Nome cientifico}

Piper cf solmisianum C. D. C.

Potomorphe cf umbellata

Potomorphe umbellata (L.) Miq.

Piper cernuum Vellozo

Polygonum cf pontudo

Polygonum hydropiperoides Michx.

Strychnos sp

Clematis dioica var. brasiliana (D.C.) Eichler

Psychotria sp

Psychotria sp

Psychotria $\mathrm{sp}$

Psychotria cf birotula L. B. Sm. \& Downs

Zanthoxyllum rhoifolium Lam.

Cupania oblongifolia Mart.

Cupania oblongifolia Mart.

Scoparia dulcis L.

Scoparia dulcis L.

Smilax sp

Smilax sp

Smilax fluminensis Steud.

Smilax cf subsessiliflora Duhamel

Smilax elastica Griseb.

Smilax sp

Solanum sp

Solanum inaequale Vell.

Brugmansia suaveolens (HBK ex Willd) Bercht. \& Presl. 


\section{Familia}

Solanaceae

Theaceae

Umbelliferae

Urticaceae

Urticaceae

Verbenaceae

Verbenaceae

Verbenaceae

Zingiberaceae

Zingiberaceae

Zingiberaceae

Zingiberaceae

Zingiberaceae

Zingiberaceae

\section{Nome popular}

trombeteira

chá-preto

centela

parietária

urtiga 1

cambará

carrapicho-de-carneiro

gervão-roxo

capitiu

curcuma-longa

curucuma-longa

napoleão

napoleão

zedoária

\section{Nome científico}

Brugmansia cf suaveolens Bercht. \& Press.

Thea sinensis $\mathrm{L}$.

Centella asiatica (L.) Urb.

Phenax sonneratii (Soneratii) Wedd.

Urera nitida (Vell.) Brack

Lantana cambara $\mathrm{L}$.

Stachytarpheta cayenensis Cham..

Renealmia petasites Gagnep.

Curcuma sp

Curcuma longa

Hedychium coronarium Koenig.

Curcuma zedoaria 
Tabela 5 - Origem, uso popular e estudos sobre ação farmacológica e fitoquímica das espécies mais citadas pela amostra de extratores e produtores de plantas medicinais da região do Vale do Ribeira, SP.

\begin{tabular}{|c|c|c|c|c|}
\hline Nome científico & Nome popular & Origem & Uso popular & Ação farmacológica e toxicidade \\
\hline Ageratum conyzoides $\mathrm{L}$. & erva-de-são-joão & $\mathrm{N}$ & Diurético' & Fungicida e bactericada. \\
\hline Ageratum conyzoides $\mathrm{L}$. & erva-de-são-joão & $\mathrm{N}$ & $\begin{array}{l}\text { Afeções dos rins e da } \\
\text { bexiga }\end{array}$ & Antibacterial. \\
\hline Ageratum conyzoides L. & erva-de-são-joão & $\mathrm{N}$ & Elimina ácido úrico ${ }^{1}$ & $\begin{array}{l}\text { Atividade inseticida contra Mosca } \\
\text { domestica e Tridolium casteneum. }\end{array}$ \\
\hline Ageratum conyzoides $\mathrm{L}$. & erva-de-são-joão & $\mathrm{N}$ & Hemorragias nasais $^{1}$ & Anti-inflamátorio, analgésico e antipirético. \\
\hline Ageratum conyzoides $\mathrm{L}$. & erva-de-são-joão & $\mathrm{N}$ & Calcificante de fraturas ${ }^{\prime}$ & Antibacterial. \\
\hline Ageratum conyzoides $\mathrm{L}$. & erva-de-são-joão & $\mathrm{N}$ & Anemia. ${ }^{\prime}$ & $\begin{array}{l}\text { Ação ovicida, indução de esterilidade, } \\
\text { inibição de desenvolvimento ovariano. }\end{array}$ \\
\hline Ageratum conyzoides $\mathrm{L}$. & erva-de-são-joão & $\mathrm{N}$ & Machucadura externa ${ }^{2}$ & $\begin{array}{l}\text { Atividade inseticida contra Mosca } \\
\text { domestica e Tridolium casteneum. }\end{array}$ \\
\hline Ageratum conyzoides $\mathrm{L}$. & erva-de-são-joão & $N$ & Menstruação suspensa $^{2}$ & Fungicida e bactericada. \\
\hline Ageratum conyzoides $\mathrm{L}$. & erva-de-são-joão & $\mathrm{N}$ & $\begin{array}{l}\text { Tosse com catarro e tosse } \\
\text { comprida }^{2}\end{array}$ & Anti-inflamátorio, analgésico e antipirético. \\
\hline Ageratum conyzoides $\mathrm{L}$. & erva-de-são-joão & $N$ & & $\begin{array}{l}\text { Ação ovicida, indução de esterilidade, } \\
\text { inibição de desenvolvimento ovariano. }\end{array}$ \\
\hline $\begin{array}{l}\text { Baccharis cf gaudichaudiana A. P. De } \\
\text { Candolle }\end{array}$ & carqueja & $\mathrm{N}$ & $\begin{array}{l}\text { Febrífuga, diurética, } \\
\text { debilidade orgânica, } \\
\text { anemia. }^{3}\end{array}$ & \\
\hline Baccharis trimera (Less) DC. & carqueja & $N$ & $\begin{array}{l}\text { Diarréia do gado. } \\
\text { Esterilidade da mulher }\end{array}$ & $\begin{array}{l}\text { Atividade moluscicida, causando } 100 \% \text { de } \\
\text { mort. entre } 6-24 \mathrm{~h} \text { em Biomphalaria } \\
\text { glabrata. Profilaxia da esquistossomose. }\end{array}$ \\
\hline
\end{tabular}




\begin{tabular}{|c|c|c|c|c|}
\hline Nome cientifico & Nome popular & Origem & Uso popular & Ação farmacológica e toxicidade \\
\hline Baccharis trimera (Less) DC. & carqueja & $\mathrm{N}$ & $\begin{array}{l}\text { Hepatite, figado, disenteria, } \\
\text { nervoso }\end{array}$ & Anti-hepatotóxico. \\
\hline Baccharis cassinefolia DC. & jaborandi 1 & $\mathrm{~N}$ & & \\
\hline Bidens pilosa $\mathrm{L}$. & picão & $\mathrm{E}$ & Hepatite $^{2}$ & Anti-micobactérias da tuberculose. \\
\hline Bidens pilosa $\mathrm{L}$. & picão & $\mathrm{E}$ & Coceira de mulher ${ }^{2}$ & anti-HIV. \\
\hline Bidens pilosa $\mathrm{L}$. & picão & $\mathrm{E}$ & Ferida $^{2}$ & antitumoral. \\
\hline Bidens pilosa $\mathrm{L}$. & picão & $\mathrm{E}$ & Azia $^{2}$ & $\begin{array}{l}\text { Inibe o super crescimento em culturas de } \\
\text { células transformadas. }\end{array}$ \\
\hline Bidens pilosa $\mathrm{L}$. & picão & $\mathrm{E}$ & Disenteria $^{2}$ & Ativ. antimicrobial. \\
\hline Bidens pilosa $\mathrm{L}$. & picão & $\mathrm{E}$ & Queimaduras $^{2}$ & $\begin{array}{l}\text { Fator promotor na etiologia do câncer } \\
\text { esofágico. }\end{array}$ \\
\hline Bidens pilosa $\mathrm{L}$. & picão & $\mathrm{E}$ & & Potencial carcinogênico. \\
\hline Bidens pilosa $\mathrm{L}$. & picão & $\mathrm{E}$ & & $\begin{array}{l}\text { Antimicrobial I. Agentes antinflamatórios } \\
\text { II. }\end{array}$ \\
\hline Bidens pilosa $\mathrm{L}$. & picão & $\mathrm{E}$ & & fungicida. \\
\hline Casearia sylvestris $\mathrm{Sw}$. & guaçatonga & $N$ & $\begin{array}{l}\text { Halitose (mau-hálito), } \\
\text { gastrite, úlceras internas. }\end{array}$ & Ativ. citotóxica. \\
\hline Casearia sylvestris $\mathrm{Sw}$. & guaçatonga & $N$ & $\begin{array}{l}\text { Feridas, úlceras varicosas, } \\
\text { picadas de insetos, herpes } \\
\text { labial e genital, gengivite, } \\
\text { estomatite, aftas e feridas na } \\
\text { boca. }\end{array}$ & Antitumoral. \\
\hline Casearia sylvestris $\mathrm{Sw}$. & guaçatonga & $\mathrm{N}$ & $\begin{array}{l}\text { Machucadura externa e } \\
\text { interna. }\end{array}$ & Antitumoral. \\
\hline Cecropia cf glaziovi Snethl. & embaúba & $\mathrm{N}$ & Machucadura interna. ${ }^{2}$ & $\begin{array}{l}\text { Inibição das células secretoras intrínsecas } \\
\text { do "corpus cardiacum" }\end{array}$ \\
\hline
\end{tabular}




\begin{tabular}{|c|c|c|c|c|}
\hline Nome científico & Nome popular & Origem & Uso popular & Ação farmacológica e toxicidade \\
\hline Cecropia cf glaziovi Snethl. & embaúba & $N$ & $\begin{array}{l}\text { Diurético; ativador das } \\
\text { funções (cardiacas e } \\
\text { circulatórias), diabetes; } \\
\text { lavagem vaginais; } \\
\text { corrimentos vaginais, } \\
\text { afeções cutâneas; feridas; } \\
\text { afeções das vias } \\
\text { respiratórias (asma, } \\
\text { bronquite e tosses); ativador } \\
\text { das funções (cardíacas, } \text { circulatórias e }^{\text {respiratórias); }}{ }^{1}\end{array}$ & \\
\hline Cecropia cf pachystachya Trèc. & embaúba & $\mathrm{N}$ & & \\
\hline Clematis dioica var. brasiliana (D.C.) Elchler & guaco & $\mathrm{N}$ & & \\
\hline Chenopodium ambrosioides $\mathrm{L}$. & erva-de-santa-maria & $\mathrm{E}$ & Lombrigueira $^{2}$ & Ação anti-oxidante moderada. \\
\hline Chenopodium ambrosioides $\mathrm{L}$. & erva-de-santa-maria & $\mathrm{E}$ & $\begin{array}{l}\text { Machucadura interna e } \\
\text { externa. }{ }^{2}\end{array}$ & $\begin{array}{l}\text { Anti-reumático, anti-helmíntico, etc. Foi } \\
\text { feito um esforço para isolar o componente } \\
\text { que tem propriedades analgésicas e } \\
\text { sedativas. }\end{array}$ \\
\hline Chenopodium ambrosioides $\mathrm{L}$. & erva-de-santa-maria & E & $\begin{array}{l}\text { Parasitas intestinais } \\
\text { (verminoses); choques } \\
\text { traumáticos ou quedas } \\
\text { (fraturas ou } \\
\text { destrocamentos); inchaços } \\
\text { localizados }\end{array}$ & Fungicida. \\
\hline Chenopodium ambrosioides $\mathrm{L}$. & erva-de-santa-maria & $\mathrm{E}$ & $\begin{array}{l}\text { Parasitas de pele (bicho } \\
\text { geográfico). }\end{array}$ & Não é citada. \\
\hline Chenopodium ambrosioides $\mathrm{L}$. & erva-de-santa-maria & $\mathrm{E}$ & $\begin{array}{l}\text { Afeções das vias } \\
\text { respiratórias (peitoral, }\end{array}$ & $\begin{array}{l}\text { Anti-micótico ou anti-dermatófito ou } \\
\text { fungicida. }\end{array}$ \\
\hline
\end{tabular}




\begin{tabular}{|c|c|c|c|c|}
\hline Nome científico & Nome popular & Origem & Uso popular & Ação farmacológica e toxicidade \\
\hline & & & $\begin{array}{l}\text { sinusite, resfriados, gripes, } \\
\text { bronquites, catarro crônico, } \\
\text { tosses e inflamação na } \\
\text { garganta) }{ }^{1}\end{array}$ & \\
\hline Coix cf lacryma Jobi L. & capiá-rosário & $\mathrm{E}$ & Ferida $^{2}$ & $\begin{array}{l}\text { Estimula o crescimento capilar. Tônico } \\
\text { capilar. }\end{array}$ \\
\hline Coix cf lacryma Jobi $\mathrm{L}$. & capiá-rosário & $\mathrm{E}$ & & $\begin{array}{l}\text { Tônico capilar. Estimula as células } \\
\text { capilares. }\end{array}$ \\
\hline Coix cf lacryma Jobi $\mathrm{L}$. & capiá-rosário & $\mathrm{E}$ & & $\begin{array}{l}\text { Atividades farmacológicas, não } \\
\text { especificadas no resumo. }\end{array}$ \\
\hline Coix cf lacryma Jobi $\mathrm{L}$. & capiá-rosário & $\mathrm{E}$ & & $\begin{array}{l}\text { Controla os distúrbios dentais em cães e } \\
\text { gatos. }\end{array}$ \\
\hline Coix cf lacryma Jobi $\mathrm{L}$. & capiá-rosário & $\mathrm{E}$ & & $\begin{array}{l}\text { Creme de limpeza de pele contendo } \\
\text { inibidores rutino and tiroxidase. }\end{array}$ \\
\hline Coix cf lacryma Jobi $\mathrm{L}$. & capiá-rosário & $\mathrm{E}$ & & Previne distúrbios na pele. \\
\hline Coix cf lacryma Jobi L. & capiá-rosário & $\mathrm{E}$ & & antioxidante. \\
\hline Coix cf lacryma Jobi $\mathrm{L}$. & capiá-rosário & $\mathrm{E}$ & & $\begin{array}{l}\text { Anti-hipertensivo e melhora o estado } \\
\text { imune. }\end{array}$ \\
\hline Coix cf lacryma Jobi L. & capiá-rosário & $\mathrm{E}$ & & Combate o envelhecimento. \\
\hline Costus spiralis (Jacq.) Roscoe & cana-do-brejo & $\mathrm{N}$ & Vômito $^{2}$ & \\
\hline Cuphea cartaginensis (Jacq. ) Macbr. & erva-de-sete-sangrias & $\mathrm{N}$ & $\begin{array}{l}\text { Arteriosclerose; hipertensão } \\
\text { arterial; palpitações no } \\
\text { coração; diurético, tosse dos } \\
\text { cardiacos; respiração dificil; } \\
\text { irritação das vias } \\
\text { respiratórias; insônia; } \\
\text { ativador (circulação }\end{array}$ & \\
\hline
\end{tabular}




\begin{tabular}{|c|c|c|c|c|}
\hline Nome científico & Nome popular & Origem & Uso popular & Ação farmacológica e toxicidade \\
\hline & & & $\begin{array}{l}\text { sanguíneas e função } \\
\text { intestinal) } \\
\text { nervosissmo,depurativo, } \\
\text { afecções da pele (psoríases, } \\
\text { eczemas, feridas, úlceras, } \\
\text { furúnculos, pruridos e } \\
\text { dermatite de contato). }\end{array}$ & \\
\hline $\begin{array}{l}\text { Echinodorus grandiflorus (Cham. et Schlecht.) } \\
\text { Mich. }\end{array}$ & chapéu-de-couro & $\mathrm{N}$ & Fígado e reumatismo ${ }^{2}$ & \\
\hline $\begin{array}{l}\text { Echinodorus grandiflorus (Cham. et Schlecht.) } \\
\text { Mich. }\end{array}$ & chapéu-de-couro & $\mathrm{N}$ & $\begin{array}{l}\text { Diurético; afeções renais } \\
\text { (inflamação na bexiga e } \\
\text { cálculo); reumatismo; gota } \\
\text { reumática, dores } \\
\text { nevrálgicas; prostatite; } \\
\text { afeções da garganta } \\
\text { (amigdalite e faringite); } \\
\text { estomatite, gengivite. }\end{array}$ & \\
\hline $\begin{array}{l}\text { Hymenaea cf courbaril L. var. - altissima } \\
\text { (Ducke) Lee \& Lang. }\end{array}$ & jatobá & $\mathrm{N}$ & $\begin{array}{l}\text { Diarréias; disenterias, } \\
\text { cólicas intestinais, afeções } \\
\text { das vias urinárias, cistite } \\
\text { crônica, prostatite; tosses, } \\
\text { bronquites; catarro; asma; } \\
\text { fraqueza pulmonar; } \\
\text { alimento natural. }\end{array}$ & $\begin{array}{l}\text { Inibidores da histamina e da hyalurodinase. } \\
\text { anti-histamínico. }\end{array}$ \\
\hline $\begin{array}{l}\text { Hymenaea cf courbaril L. var. - altissima } \\
\text { (Ducke) Lee \& Lang. }\end{array}$ & & $N$ & & Inibidores da testosterone-5a-reductase. \\
\hline $\begin{array}{l}\text { Hymenaea cf courbaril L. var. - altissima } \\
\text { (Ducke) Lee \& Lang. }\end{array}$ & & $N$ & & Anticoagulante. \\
\hline Jacaranda puberula Cham. & carobinha 1 & $\mathrm{~N}$ & Depurativo, anti- & \\
\hline
\end{tabular}




\begin{tabular}{|c|c|c|c|c|}
\hline Nome científico & Nome popular & Origem & Uso popular & Ação farmacológica e toxicidade \\
\hline & & & syphilitico $^{3}$ & \\
\hline Mikania cf. hirsutissima D.C. & cipó-cabeludo & $\mathrm{N}$ & $\begin{array}{l}\text { Diarréia crônica, nas } \\
\text { paralisias, reumatismo, } \\
\text { dores nas costas, nevralgias } \\
\text { e nefrites. }{ }^{3}\end{array}$ & \\
\hline Momordica cf charantia $\mathrm{L}$. & $\begin{array}{l}\text { melão-de-são-caetan } \\
0\end{array}$ & $\mathrm{~N}$ & $\begin{array}{l}\text { Inflamações do figado, } \\
\text { embaraços gástricos, cólicas } \\
\text { abdominais, menstruações } \\
\text { dificeis, queimaduras, } \\
\text { cravos e morféia. Purgativa, } \\
\text { febrífuga, vermífuga, anti- } \\
\text { reumática, supurativa }^{3} \\
\end{array}$ & \\
\hline Ocotea cf odorifera (Vell.) Rohwer & & $\mathrm{N}$ & & \\
\hline \multicolumn{5}{|l|}{ Ocotea dispersa (Nees.) Mez. } \\
\hline Phyllanthus niruri $\mathrm{L}$. & quebra-pedra 1 & $\mathrm{~N}$ & $\begin{array}{l}\text { Dor nas cadeira, urina } \\
\text { presa. }^{2}\end{array}$ & $\begin{array}{l}\text { Inibe as células musculares aórticas do } \\
\text { tórax de rato. }\end{array}$ \\
\hline Phyllanthus niruri L. & & $\mathrm{N}$ & & Anti-HIV. \\
\hline Phyllanthus niruri $\mathrm{L}$. & & $\mathrm{N}$ & & antiviral \\
\hline Phyllanthus niruri $\mathrm{L}$. & & $\mathrm{N}$ & & Não cita no resumo. \\
\hline Phyllanthus niruri $\mathrm{L}$. & & $\mathrm{N}$ & & Combate o envelhecimento. \\
\hline Phyllanthus tenelus Roxb. & & $\mathrm{E}$ & & \\
\hline Phyllanthus urinaria $\mathrm{L}$. & quebra-pedra 1 & $\mathrm{~N}$ & $\begin{array}{l}\text { Diurético; sudorífero; } \\
\text { diabetes; icterícia; febres } \\
\text { palustres e afeções } \\
\text { urinárias; afeções de pele, } \\
\text { febrífugo, males do ventre; } \\
\text { tônico. }\end{array}$ & \\
\hline
\end{tabular}




\begin{tabular}{|c|c|c|c|c|}
\hline Nome científico & Nome popular & Origem & Uso popular & Ação farmacológica e toxicidade \\
\hline \multicolumn{5}{|l|}{ Polygonum cf. pontudo } \\
\hline Schinus cf terebinthifolius Raddi. & arrueira & $\mathbf{N}$ & $\begin{array}{l}\text { Doenças na córnea, } \\
\text { depurativa, febrifuga, } \\
\text { afeções uterinas, úlceras, } \\
\text { feridas, anti-reumática, } \\
\text { diurética, }^{3}\end{array}$ & $\begin{array}{l}\text { Irritação da mucosa da membrana labial e } \\
\text { do estômago. }\end{array}$ \\
\hline Schinus cf terebinthifolius Raddi. & arrueira & $\mathrm{N}$ & & $\begin{array}{l}\text { Atividade inibitória contra "xanthine } \\
\text { oxidase"de leite de vaca, efeito antipirético. }\end{array}$ \\
\hline Senna multijuga (Rich.) Irwin \& Barneby & sene & $\mathrm{N}$ & & \\
\hline Senna occidentalis (L.) Link & fedegoso & $N$ & $\begin{array}{l}\text { Machucadura externa e } \\
\text { interna, febre, gripe, ferida, } \\
\text { dor de barriga (cólica), } \\
\text { friagem, nervoso }\end{array}$ & $\begin{array}{l}\text { Inibição de células KB (carcinoma } \\
\text { epidermoide humano de boca). }\end{array}$ \\
\hline Senna occidentalis (L.) Link & fedegoso & $\mathrm{N}$ & & Venenosa, causa miopatia em gado. \\
\hline Senna occidentalis (L.) Link & fedegoso & $\mathrm{N}$ & & Antibiótico \\
\hline Senna occidentalis (L.) Link & fedegoso & $\mathrm{N}$ & & Não apresenta toxicidade. \\
\hline Senna occidentalis (L.) Link & fedegoso & $\mathrm{N}$ & & $\begin{array}{l}\text { Anticonvulxsivo e antidiurético em } \\
\text { crianças. }\end{array}$ \\
\hline Senna occidentalis (L.) Link & fedegoso & $\mathrm{N}$ & & $\begin{array}{l}\text { Anticonvulxsivo e antidiurético em } \\
\text { crianças. }\end{array}$ \\
\hline Senna occidentalis (L.) Link & fedegoso & $N$ & & Venenosa, causa miopatia em gado. \\
\hline Senna occidentalis (L.) Link & fedegoso & $\mathbf{N}$ & & $\begin{array}{l}\text { Inibição de células KB (carcinoma } \\
\text { epidermoide humano de boca). }\end{array}$ \\
\hline Senna occidentalis (L.) Link & fedegoso & $\mathrm{N}$ & & Não apresenta toxicidade. \\
\hline Senna occidentalis (L.) Link & fedegoso & $\mathrm{N}$ & & Rejuvenecedor \\
\hline Senna occidentalis (L.) Link & fedegoso & $\mathrm{N}$ & & \\
\hline
\end{tabular}




\begin{tabular}{|c|c|c|c|c|}
\hline Nome científico & Nome popular & Origem & Uso popular & Ação farmacológica e toxicidade \\
\hline Senna occidentalis (L.) Link & fedegoso & $\mathrm{N}$ & & Antibiótico \\
\hline Senna occidentalis (L.) Link & fedegoso & $\mathrm{N}$ & & \\
\hline Senna occidentalis (L.) Link & fedegoso & $\mathrm{N}$ & & Rejuvenecedor \\
\hline Sorocea cf bonplandii (Baill.) W. C. Burguer & espinheira-santa & $\mathrm{N}$ & & \\
\hline Vernonia sp. & assa-peixe & $\mathrm{N}$ & Barriga empantuada ${ }^{2}$ & \\
\hline Zollernia cf ilicifolia (Brongn.) Vog. & espinheira-santa & $\mathrm{N}$ & & \\
\hline
\end{tabular}

Legenda:

$\mathrm{N}=$ nativa $; \mathrm{E}=$ exótica.

'.PANIZZA, 1997; ${ }^{2}$ BORN et al., 1989; ${ }^{3}$ PIO CORRÊA, 1978. 
Tabela 17 - Manejo tradicional detalhado e as formas de transporte para as plantas mais citadas pela amostra de extratores e produtores de plantas medicinais da região do Vale do Ribeira, SP.

\begin{tabular}{|c|c|c|}
\hline Nome popular & Parte extraída & Manejo tradicional detalhado \\
\hline arrueira & Casca do caule & Medi 2 palmos do chão p/cima até $1 \mathrm{~m}$, passa o facão, risca e tira a casca de um lado (50\%) \\
\hline arrueira & Fruto & Poda o ramo com frutos \\
\hline arrueira & Ramo & $\begin{array}{l}\text { Poda } 100 \% \text { dos individuos com até } 6 \text { polegadas de diâmetro do caule (seleciona os mais baixos) até onde } \\
\text { há folha no ramo, deixa os "olhos" (gemas) do ramo. }\end{array}$ \\
\hline arrueira & Resina & $\begin{array}{l}\text { Machuca c/facão p/sangrar e no dia seguinte vai recolher e machuca novamente( ou seja, corta o caule } \\
\text { com um facão para exsudar a resina, e no dia seguinte recolhi e repeti o procedimento) }\end{array}$ \\
\hline assa-peixe & Ramo & $\begin{array}{l}\text { Poda } 100 \% \text { dos individuos com até } 6 \text { polegadas de diâmetro do caule (seleciona os mais baixos) até onde } \\
\text { há folha no ramo, deixa os "olhos" (gemas) do ramo. }\end{array}$ \\
\hline assa-peixe & Raiz & Mete a enxada e tira, corta na "cabeça" e leva só a raiz (Remoção da planta) \\
\hline cana-do-brejo & Parte aérea & Corta bem rente ao chão, deixando a raiz. \\
\hline capiá-rosário & Planta toda & Corta a planta. \\
\hline capiá-rosário & Fruto & Recolhe do chão e coleta quando estão maduros \\
\hline carobinha 1 & Ramo & $\begin{array}{l}\text { Poda } 100 \% \text { dos indivíduos com até } 6 \text { polegadas de diâmetro do caule (seleciona os mais baixos) até onde } \\
\text { há folha no ramo, deixa os "olhos" (gemas) do ramo. }\end{array}$ \\
\hline carqueja & Parte aérea & Corta a parte verde; mais ou menos Imetro $(40-80 \mathrm{~cm}$ folha seca, pois parte útil é pouca) \\
\hline chapéu-de-couro & Folha & Corte principalmente das folhas \\
\hline chapéu-de-couro & Parte aérea & Corte principalmente das folhas \\
\hline cipó-cabeludo & Cipó & Tira tudo acima de $70 \mathrm{~cm}$ do chão para que ele brote novamente. \\
\hline cipó-cravo & Parte aérea & Corta toda a parte aérea da planta para aproveitar o lenho \\
\hline embaúba & Folha & Derruba a planta para retirar as folhas velhas e os brotos \\
\hline erva-de-bicho & Parte aérea & Arranca a planta c/raiz e tudo (Remoção da plantas) \\
\hline erva-de-bicho & Planta toda & Arranca a planta c/raiz e tudo (Remoção da plantas) \\
\hline erva-de-são-joão & Planta toda & Arranca a planta c/raiz e tudo (Remoção da plantas) \\
\hline erva-de-são-joão & Parte aérea & Arranca a planta c/raiz e tudo (Remoção da plantas) \\
\hline erva-de-sete-sangrias & Planta toda & Arranca a planta c/raiz e tudo (Remoção da plantas) \\
\hline erva-de-santa-maria & Planta toda & Arranca a planta c/raiz e tudo (Remoção da plantas) \\
\hline erva-de-santa-maria & Parte aérea & Arranca a planta c/raiz e tudo (Remoção da plantas) \\
\hline
\end{tabular}




\begin{tabular}{|c|c|c|}
\hline Nome popular & Parte extraida & Manejo tradicional detalhado \\
\hline espinheira-santa 1 & Ramo & $\begin{array}{l}\text { Poda } 100 \% \text { dos indivíduos com até } 6 \text { polegadas de diâmetro do caule (seleciona os mais baixos) até onde } \\
\text { há folha no ramo, deixa os "olhos" (gemas) do ramo. }\end{array}$ \\
\hline fedegoso & Planta toda & Arranca a planta c/raiz e tudo (Remoção da plantas) \\
\hline fedegoso & Raiz & Arranca a planta c/raiz e tudo (Remoção da plantas) \\
\hline guaçatonga & Ramo & Poda todos os ramos para rebaixar a planta; deixa os "olhos" do ramo (tira até onde têm folha) \\
\hline guaco & Ramo & Tira tudo acima de $70 \mathrm{~cm}$ do chão p/ele brotar novamente. \\
\hline jaborandi 1 & Ramo & Poda todos os ramos para rebaixar a planta; deixa os "olhos" do ramo (tira até onde têm folha) \\
\hline jatobá & Casca do caule & Medi 2 palmos do chão p/cima até $1 \mathrm{~m}$, passa o facão, risca e tira a casca de um lado $(50 \%)$ \\
\hline jatobá & Semente & Recolhe do chão. \\
\hline jatobá & Resina & $\begin{array}{l}\text { Machuca c/facão p/sangrar e no dia seguinte vai recolher e machuca novamente( ou seja, corta o caule } \\
\text { com um facão para exsudar a resina, e no dia seguinte recolhi e repeti o procedimento) }\end{array}$ \\
\hline melão-de-são-caetano & Parte aérea & Corta rente ao chão. \\
\hline pata-de-vaca & Ramo & $\begin{array}{l}\text { Sistema de poda: Poda todos os ramos para rebaixar a planta; deixa os "olhos" do ramo (tira até onde têm } \\
\text { folha) }\end{array}$ \\
\hline picão & Parte aérea & Remoção de toda planta \\
\hline picão-preto & Planta toda & Remoção de toda planta \\
\hline quebra-pedra 1 & Planta toda & Remoção de toda planta \\
\hline salssaparrilha 1 & Raiz & $\begin{array}{l}\text { Maneja a planta "mãe" até brotar o broto. Enquanto não brota, tira só } 1 \text { raiz, ao nascer e crescer o broto } \\
\text { (até a altura de } 2 \mathrm{~m} \text { ) poda o broto para não crescer. }\end{array}$ \\
\hline salssaparrilha 1 & Planta toda & Remoção de toda planta \\
\hline sassafrás 1 & Lenho & $\begin{array}{l}\text { Maneja a planta "mãe" até brotar o broto. Enquanto não brota, tira só } 1 \text { raiz, ao nascer e crescer o broto } \\
\text { (até a altura de } 2 \mathrm{~m} \text { ) poda o broto para não crescer. }\end{array}$ \\
\hline sassafrás 1 & Raiz & $\begin{array}{l}\text { Maneja a planta "mãe" até brotar o broto. Enquanto não brota, tira só } 1 \text { raiz, ao nascer e crescer o broto } \\
\text { (até a altura de } 2 \mathrm{~m} \text { ) poda o broto para não crescer. }\end{array}$ \\
\hline sassafrás 1 & Casca do caule & Medi 2 palmos do chão p/cima até $1 \mathrm{~m}$, passa o facão, risca e tira a casca de um lado (50\%) \\
\hline sene & Ramo & $\begin{array}{l}\text { poda } 100 \% \text { dos individuos. até } 6 \text { polegadas de diâmetro. do caule (mais baixas), aonde tiver folha no } \\
\text { ramo, qualquer/folha, deixa os "olhos" do ramo }\end{array}$ \\
\hline
\end{tabular}


Tabela 26 - Parte extraída, forma de secagem e de embalagem, rendimento, preço e compradores das plantas mais citadas pela amostra de extratores e produtores de plantas medicinais da região do Vale do Ribeira, SP.

\begin{tabular}{|c|c|c|c|c|c|c|}
\hline Nome da Planta & Parte Vendida & Forma de Secagem & $\begin{array}{c}\text { Relação } \\
\text { Peso seco/Peso fresco }\end{array}$ & Forma de Embalagem & Preço(R\$/Kg) & Compradores \\
\hline arrueira & Casca do caule & Forno - Fechado & $\overline{S / F}$ & Saquinhos de $30 \mathrm{~g}$ & $>20$ & Laboratórios \\
\hline arrueira & Folha & Forno - Fechado & $6 / 1 \bullet \cdots--8 / 1$ & Saquinhos de $30 \mathrm{~g}$ & $>20$ & Laboratórios \\
\hline arrueira & Resina & & 6/1 •---- 8/1 & Potes da coleta $(200 \mathrm{~g})$ & $>20$ & Laboratórios \\
\hline assa-peixe & Folha & Ao sol & $\mathrm{S} / \mathrm{F}$ & A granel em sacos de $60 \mathrm{Kg}$ & $1 \bullet-\cdots 5$ & Atacadistas \\
\hline assa-peixe & Raiz & Forno - Fechado & $\mathrm{S} / \mathrm{F}$ & Saquinhos de $30 \mathrm{~g}$ & $>20$ & Laboratórios \\
\hline assa-peixe & Raiz & $\mathrm{Na}$ sombra & $\mathrm{S} / \mathrm{F}$ & Saquinhos de $30 \mathrm{~g}$ & $>20$ & Laboratórios \\
\hline assa-peixe & Ramo & Forno - Aberto & $8 / 1 \bullet \cdots-\cdots 10 / 1$ & A granel em sacos de $60 \mathrm{Kg}$ & $\mathrm{S} / \mathrm{F}$ & Atacadistas \\
\hline cana-do-brejo & Parte aérea & Ao sol & $>10 / 1$ & A granel em sacos de $60 \mathrm{Kg}$ & $1 \bullet-\ldots-\ldots$ & Atacadistas \\
\hline cana-do-brejo & Parte aérea & Forno - Fechado & $>10 / 1$ & A granel em sacos de $60 \mathrm{Kg}$ & $\mathrm{S} / \mathrm{F}$ & Laboratórios \\
\hline cana-do-brejo & Parte aérea & Forno - Fechado & $\mathrm{S} / \mathrm{F}$ & Saquinhos de $30 \mathrm{~g}$ & $>20$ & Laboratórios \\
\hline cana-do-brejo & Parte aérea & Forno - Fechado & 6/1 •---- 8/1 & $\mathrm{S} / \mathrm{F}$ & $\mathrm{S} / \mathrm{F}$ & Laboratórios \\
\hline capiá-rosário & Planta toda & Ao sol & $<2 / 1$ & A granel em sacos de $60 \mathrm{Kg}$ & $1 \cdot \ldots-\ldots$ & Atacadistas \\
\hline capiá-rosário & Semente & Ao sol & $>10 / 1$ & A granel em sacos de $60 \mathrm{Kg}$ & 1 •----- 5 & Atacadistas \\
\hline carobinha 1 & Folha & Forno - Fechado & $4 / 1 \cdot \cdots---6 / 1$ & Saquinhos de $30 \mathrm{~g}$ & $>20$ & $\begin{array}{l}\text { Lojas de produtos } \\
\text { naturais }\end{array}$ \\
\hline carobinha 1 & Folha & Forno - Fechado & 4/1 ----- 6/1 & outros & $>20$ & Laboratórios \\
\hline carobinha 1 & Folha & Forno - Fechado & $\mathrm{S} / \mathrm{F}$ & Saquinhos de $30 \mathrm{~g}$ & $>20$ & Laboratórios \\
\hline carqueja & Folha & $\mathrm{S} / \mathrm{F}$ & $\mathrm{S} / \mathrm{F}$ & $\mathrm{S} / \mathrm{F}$ & $\mathrm{S} / \mathrm{F}$ & Atacadistas \\
\hline carqueja & Parte aérea & Ao sol & $>10 / 1$ & A granel em sacos de $60 \mathrm{Kg}$ & $1 \bullet \ldots 5$ & Atacadistas \\
\hline carqueja & Parte aérea & Forno - Fechado & 8/1 •---- $10 / 1$ & Saquinhos de $30 \mathrm{~g}$ & $>20$ & $\begin{array}{l}\text { Lojas de produtos } \\
\text { naturais }\end{array}$ \\
\hline carqueja & Parte aérea & Forno - Fechado & $\mathrm{S} / \mathrm{F}$ & Saquinhos de $30 \mathrm{~g}$ & $>20$ & Laboratórios \\
\hline carqueja & Parte aérea & Forno - Fechado & $\mathrm{S} / \mathrm{F}$ & A granel em sacos de $60 \mathrm{Kg}$ & $\mathrm{S} / \mathrm{F}$ & Laboratórios \\
\hline
\end{tabular}




\begin{tabular}{|c|c|c|c|c|c|c|}
\hline Nome da Planta & Parte Vendida & Forma de Secagem & $\begin{array}{c}\text { Relação } \\
\text { Peso seco/Peso fresco }\end{array}$ & Forma de Embalagem & Preço(R\$/Kg) & Compradores \\
\hline chapé-de-couro & Folha & Ao sol & $>10 / 1$ & A granel em sacos de $60 \mathrm{Kg}$ & $1 \bullet----5$ & Atacadistas \\
\hline chapé-de-couro & Folha & Forno - Fechado & $2 / 1 \bullet-\ldots-.4 / 1$ & Saquinhos de $30 \mathrm{~g}$ & $>20$ & $\begin{array}{l}\text { Lojas de produtos } \\
\text { naturais }\end{array}$ \\
\hline chapé-de-couro & Folha & Forno - Fechado & $>10 / 1$ & Saquinhos de $30 \mathrm{~g}$ & $>20$ & Laboratórios \\
\hline cipó-cabeludo & Cipó & Forno - Fechado & $>10 / 1$ & Saquinhos de $30 \mathrm{~g}$ & $>20$ & Laboratórios \\
\hline cipó-cabeludo & Cipó & Forno - Fechado & $>10 / 1$ & Saquinhos de $30 \mathrm{~g}$ & $>20$ & $\begin{array}{l}\text { Lojas de produtos } \\
\text { naturais }\end{array}$ \\
\hline cipó-cabeludo & Folha & Forno - Fechado & $\mathrm{S} / \mathrm{F}$ & Saquinhos de $30 \mathrm{~g}$ & $>20$ & $\begin{array}{l}\text { Lojas de produtos } \\
\text { naturais }\end{array}$ \\
\hline cipó-cabeludo & Ramo & Forno - Fechado & $<2 / 1$ & A granel em sacos de $60 \mathrm{Kg}$ & $\mathrm{S} / \mathrm{F}$ & Laboratórios \\
\hline cipó-cravo & cipó & Forno - Fechado & $\mathrm{S} / \mathrm{F}$ & $\mathrm{S} / \mathrm{F}$ & $\mathrm{S} / \mathrm{F}$ & Laboratórios \\
\hline cipó-cravo & cipó & Forno - Fechado & $2 / 1 \bullet----4 / 1$ & A granel em sacos de $60 \mathrm{Kg}$ & $\mathrm{S} / \mathrm{F}$ & Laboratórios \\
\hline cipó-cravo & Lenho & Forno - Fechado & $\mathrm{S} / \mathrm{F}$ & Saquinhos de $30 \mathrm{~g}$ & $>20$ & Laboratórios \\
\hline embaúba & Folha & Ao sol & $>10 / 1$ & A granel em sacos de $60 \mathrm{Kg}$ & $1 \bullet----5$ & Atacadistas \\
\hline embaúba & Folha & Forno - Fechado & 6/1 •---- 8/1 & Saquinhos de $30 \mathrm{~g}$ & $>20$ & $\begin{array}{l}\text { Lojas de produtos } \\
\text { naturais }\end{array}$ \\
\hline embaúba & Folha & Forno - Fechado & $>10 / 1$ & Saquinhos de $30 \mathrm{~g}$ & $>20$ & Laboratórios \\
\hline erva-de-bicho & Parte aérea & Forno - Fechado & $6 / 1 \bullet-\ldots-.8 / 1$ & A granel em sacos de $60 \mathrm{Kg}$ & $\mathrm{S} / \mathrm{F}$ & Laboratórios \\
\hline erva-de-bicho & Planta toda & Ao sol & $\mathrm{S} / \mathrm{F}$ & A granel em sacos de $60 \mathrm{Kg}$ & $1 \cdot \cdots-5$ & Atacadistas \\
\hline erva-de-santa-maria & Parte aérea & Forno - Fechado & 6/1 o----- 8/1 & A granel em sacos de $60 \mathrm{Kg}$ & $\mathrm{S} / \mathrm{F}$ & Laboratórios \\
\hline erva-de-santa-maria & Planta toda & Ao sol & $>10 / 1$ & A granel em sacos de $60 \mathrm{Kg}$ & $1 \cdot \ldots-\ldots$ & Atacadistas \\
\hline erva-de-santa-maria & Planta toda & Forno - Fechado & $\mathrm{S} / \mathrm{F}$ & Saquinhos de $30 \mathrm{~g}$ & $>20$ & Laboratórios \\
\hline erva-de-são-joão & Parte aérea & Forno - Fechado & $\mathrm{S} / \mathrm{F}$ & A granel em sacos de $60 \mathrm{Kg}$ & $\mathrm{S} / \mathrm{F}$ & Laboratórios \\
\hline erva-de-são-joão & Planta toda & Ao sol & 2/1 •--.- 4/1 & A granel em sacos de $60 \mathrm{Kg}$ & $1 \cdot \ldots-5$ & Atacadistas \\
\hline erva-de-são-joão & Planta toda & Forno - Fechado & $\mathrm{S} / \mathrm{F}$ & Saquinhos de $30 \mathrm{~g}$ & $>20$ & Laboratórios \\
\hline erva-de-sete-sangrias & Planta toda & Ao sol & $\mathrm{S} / \mathrm{F}$ & A granel em sacos de $60 \mathrm{Kg}$ & $1 \bullet-\ldots-5$ & Atacadistas \\
\hline
\end{tabular}




\begin{tabular}{|c|c|c|c|c|c|c|}
\hline Nome da Planta & Parte Vendida & Forma de Secagem & $\begin{array}{c}\text { Relação } \\
\text { Peso seco/Peso fresco }\end{array}$ & Forma de Embalagem & Preço(R\$/Kg) & Compradores \\
\hline erva-de-sete-sangrias & Planta toda & Forno - Aberto & $>10 / 1$ & A granel em sacos de $60 \mathrm{Kg}$ & $\mathrm{S} / \mathrm{F}$ & Atacadistas \\
\hline erva-de-sete-sangrias & Planta toda & Forno - Fechado & $2 / 1 \bullet-----4 / 1$ & Saquinhos de $30 \mathrm{~g}$ & $>20$ & $\begin{array}{l}\text { Lojas de produtos } \\
\text { naturais }\end{array}$ \\
\hline erva-de-sete-sangrias & Planta toda & Forno - Fechado & $2 / 1 \bullet-\cdots--4 / 1$ & Saquinhos de $30 \mathrm{~g}$ & $>20$ & Laboratórios \\
\hline erva-de-sete-sangrias & Planta toda & Na sombra & $4 / 1 \bullet----6 / 1$ & Saquinhos de $30 \mathrm{~g}$ & $>20$ & Laboratórios \\
\hline espinheira-santa 1 & Folha & Forno - Fechado & $8 / 1 \bullet-\cdots--10 / 1$ & Saquinhos de $30 \mathrm{~g}$ & $>20$ & Laboratórios \\
\hline espinheira-santa 1 & Folha & Forno - Fechado & $>10 / 1$ & Saquinhos de $30 \mathrm{~g}$ & $>20$ & $\begin{array}{l}\text { Lojas de produtos } \\
\text { naturais }\end{array}$ \\
\hline fedegoso & Folha & Forno - Fechado & 6/1 •----- 8/1 & Saquinhos de $30 \mathrm{~g}$ & $>20$ & Laboratórios \\
\hline fedegoso & Raiz & Ao sol & $>10 / 1$ & A granel em sacos de $60 \mathrm{Kg}$ & $1 \bullet----5$ & Atacadistas \\
\hline fedegoso & Raiz & Forno - Fechado & $>10 / 1$ & Saquinhos de $30 \mathrm{~g}$ & $>20$ & Laboratórios \\
\hline guaçatonga & Folha & Forno - Fechado & $<2 / 1$ & Saquinhos de $30 \mathrm{~g}$ & $>20$ & $\begin{array}{l}\text { Lojas de produtos } \\
\text { naturais }\end{array}$ \\
\hline guaçatonga & Folha & Forno - Fechado & $6 / 1 \bullet \ldots . .-8 / 1$ & outros & $\mathrm{S} / \mathrm{F}$ & Laboratórios \\
\hline guaçatonga & Folha & Forno - Fechado & $\mathrm{S} / \mathrm{F}$ & Saquinhos de $30 \mathrm{~g}$ & $>20$ & Laboratórios \\
\hline guaçatonga & Folha & Forno - Fechado & $2 / 10-\cdots--4 / 1$ & A granel em sacos de $60 \mathrm{Kg}$ & $\mathrm{S} / \mathrm{F}$ & Laboratórios \\
\hline guaçatonga & Ramo & Forno - Aberto & $\mathrm{S} / \mathrm{F}$ & $\mathrm{S} / \mathrm{F}$ & $\mathrm{S} / \mathrm{F}$ & Atacadistas \\
\hline guaçatonga & Ramo & Forno - Aberto & $>10 / 1$ & A granel em sacos de $60 \mathrm{Kg}$ & $\mathrm{S} / \mathrm{F}$ & Atacadistas \\
\hline guaco & Cipó & Forno - Fechado & $>10 / 1$ & Saquinhos de $30 \mathrm{~g}$ & $>20$ & $\begin{array}{l}\text { Lojas de produtos } \\
\text { naturais }\end{array}$ \\
\hline guaco & Folha & Forno - Fechado & $8 / 1 \bullet \ldots-\ldots-10 / 1$ & Saquinhos de $30 \mathrm{~g}$ & $>20$ & $\begin{array}{l}\text { Lojas de produtos } \\
\text { naturais }\end{array}$ \\
\hline guaco & Folha & Forno - Fechado & $<2 / 1$ & Saquinhos de $30 \mathrm{~g}$ & $>20$ & Laboratórios \\
\hline guaco & Ramo & Forno - Fechado & $\mathrm{S} / \mathrm{F}$ & outros & $\mathrm{S} / \mathrm{F}$ & Laboratórios \\
\hline guaco & Ramo & Forno - Fechado & $2 / 1 \bullet \ldots-\ldots 4 / 1$ & A granel em sacos de $60 \mathrm{Kg}$ & $\mathrm{S} / \mathrm{F}$ & Laboratórios \\
\hline jaborandi 1 & Folha & Forno - Fechado & $\mathrm{S} / \mathrm{F}$ & Saquinhos de $30 \mathrm{~g}$ & $>20$ & Laboratórios \\
\hline
\end{tabular}




\begin{tabular}{|c|c|c|c|c|c|c|}
\hline Nome da Planta & Parte Vendida & Forma de Secagem & $\begin{array}{c}\text { Relação } \\
\text { Peso seco/Peso fresco }\end{array}$ & Forma de Embalagem & Preço(R\$/Kg) & Compradores \\
\hline jaborandi 1 & Ramo & Ao sol & $2 / 1 \bullet---4 / 1$ & A granel em sacos de $60 \mathrm{Kg}$ & $1 \bullet----5$ & Atacadistas \\
\hline jaborandi 1 & Ramo & Forno - Aberto & $2 / 1 \bullet-\cdots--4 / 1$ & A granel em sacos de $60 \mathrm{Kg}$ & $\mathrm{S} / \mathrm{F}$ & Atacadistas \\
\hline jatobá & Casca do caule & Ao sol & $<2 / 1$ & A granel em sacos de $60 \mathrm{Kg}$ & $1 \bullet-\cdots 5$ & Atacadistas \\
\hline jatobá & Casca do caule & Forno - Fechado & $\mathrm{S} / \mathrm{F}$ & Saquinhos de $30 \mathrm{~g}$ & $>20$ & Laboratórios \\
\hline jatobá & Semente & Ao sol & $\mathrm{S} / \mathrm{F}$ & A granel em sacos de $60 \mathrm{Kg}$ & $1 \bullet \cdots 5$ & Atacadistas \\
\hline jatobá & Resina & & $>10 / 1$ & Potes da coleta & $>20$ & Laboratórios \\
\hline melão-de-são-caetano & Folha & Ao sol & $4 / 1 \bullet-\cdots--6 / 1$ & A granel em sacos de $60 \mathrm{Kg}$ & $1 \bullet \cdots--5$ & Atacadistas \\
\hline melão-de-são-caetano & Parte aérea & Forno - Fechado & $>10 / 1$ & Saquinhos de $30 \mathrm{~g}$ & $>20$ & Laboratórios \\
\hline melão-de-são-caetano & Parte aérea & Forno - Fechado & $\mathrm{S} / \mathrm{F}$ & A granel em sacos de $60 \mathrm{Kg}$ & $\bar{S} / \mathrm{F}$ & Laboratórios \\
\hline melão-de-são-caetano & Planta toda & Forno - Fechado & $>10 / 1$ & A granel em sacos de $60 \mathrm{Kg}$ & $\mathrm{S} / \mathrm{F}$ & Laboratórios \\
\hline pata-de-vaca & Folha & Ao sol & $6 / 1 \cdot \cdots--.8 / 1$ & A granel em sacos de $60 \mathrm{Kg}$ & $1 \bullet \cdots-\ldots$ & Atacadistas \\
\hline pata-de-vaca & Folha & Forno - Fechado & 6/1 - ---- 8/1 & Saquinhos de $30 \mathrm{~g}$ & $>20$ & $\begin{array}{l}\text { Lojas de produtos } \\
\text { naturais }\end{array}$ \\
\hline pata-de-vaca & Folha & Forno - Fechado & $\mathrm{S} / \mathrm{F}$ & Sacos de $01 \mathrm{Kg}$ & $>20$ & Laboratórios \\
\hline pata-de-vaca & Folha & Forno - Fechado & $\mathrm{S} / \mathrm{F}$ & Saquinhos de $30 \mathrm{~g}$ & $>20$ & Laboratórios \\
\hline pata-de-vaca & Folha & $\mathrm{S} / \mathrm{F}$ & $\mathrm{S} / \mathrm{F}$ & $\mathrm{S} / \mathrm{F}$ & $\mathrm{S} / \mathrm{F}$ & $\mathrm{S} / \mathrm{F}$ \\
\hline picão & Parte aérea & Forno - Aberto & $\mathrm{S} / \mathrm{F}$ & A granel em sacos de $60 \mathrm{Kg}$ & $\mathrm{S} / \mathrm{F}$ & Atacadistas \\
\hline picão & Parte aérea & Forno - Fechado & $>10 / 1$ & A granel em sacos de $60 \mathrm{Kg}$ & $\mathrm{S} / \mathrm{F}$ & Laboratórios \\
\hline picão & Parte aérea & Forno - Fechado & $>10 / 1$ & A granel em sacos de $60 \mathrm{Kg}$ & $\mathrm{S} / \mathrm{F}$ & Laboratórios \\
\hline picão-branco & Planta toda & Forno - Fechado & $8 / 1 \bullet \cdots-\ldots 10 / 1$ & Saquinhos de $30 \mathrm{~g}$ & $>20$ & Laboratórios \\
\hline picão-preto & Planta toda & Forno - Fechado & 2/1 •---- 4/1 & Saquinhos de $30 \mathrm{~g}$ & $>20$ & Laboratórios \\
\hline quebra-pedra 1 & Parte aérea & Ao sol & $\mathrm{S} / \mathrm{F}$ & A granel em sacos de $60 \mathrm{Kg}$ & $1 \bullet-\cdots--5$ & Atacadistas \\
\hline quebra-pedra 1 & Planta toda & Forno - Aberto & $>10 / 1$ & $\mathrm{~S} / \mathrm{F}$ & $\mathrm{S} / \mathrm{F}$ & Atacadistas \\
\hline quebra-pedra 1 & Planta toda & Forno - Aberto & $>10 / 1$ & A granel em sacos de $60 \mathrm{Kg}$ & $\mathrm{S} / \mathrm{F}$ & Atacadistas \\
\hline quebra-pedra 1 & Planta toda & Forno - Fechado & $2 / 1 \bullet-\cdots--4 / 1$ & A granel em sacos de $60 \mathrm{Kg}$ & $\mathrm{S} / \mathrm{F}$ & Laboratórios \\
\hline
\end{tabular}




\begin{tabular}{|c|c|c|c|c|c|c|}
\hline Nome da Planta & Parte Vendida & Forma de Secagem & $\begin{array}{c}\text { Relação } \\
\text { Peso seco/Peso fresco }\end{array}$ & Forma de Embalagem & Preço(R\$/Kg) & Compradores \\
\hline quebra-pedra 1 & Planta toda & Forno - Fechado & $\mathrm{S} / \mathrm{F}$ & A granel em sacos de $60 \mathrm{Kg}$ & $\mathrm{S} / \mathrm{F}$ & Laboratórios \\
\hline quebra-pedra 1 & Planta toda & Forno - Fechado & $2 / 1 \cdot----4 / 1$ & Saquinhos de $30 \mathrm{~g}$ & $>20$ & Laboratórios \\
\hline quebra-pedra 1 & Ramo & Forno - Aberto & $>10 / 1$ & $\mathrm{~S} / \mathrm{F}$ & $\bar{S} / \mathrm{F}$ & $\mathrm{S} / \mathrm{F}$ \\
\hline salssaparrilha 1 & Raiz & Ao sol & $8 / 1 \bullet \ldots . .-10 / 1$ & A granel em sacos de $60 \mathrm{Kg}$ & $1 \bullet----5$ & Atacadistas \\
\hline salssaparrilha 1 & Raiz & Forno - Fechado & $\mathrm{S} / \mathrm{F}$ & Saquinhos de $30 \mathrm{~g}$ & $>20$ & Laboratórios \\
\hline salssaparrilha 1 & Raiz & Forno - Fechado & $<2 / 1$ & Saquinhos de $30 \mathrm{~g}$ & $>20$ & $\begin{array}{l}\text { Lojas de produtos } \\
\text { naturais }\end{array}$ \\
\hline samambainha & Parte aérea & Ao sol & $4 / 1 \bullet----6 / 1$ & A granel em sacos de $60 \mathrm{Kg}$ & 1 e---- 5 & Atacadistas \\
\hline sassafrás 1 & Casca do caule & Ao sol & 6/1 •----- 8/1 & A granel em sacos de $60 \mathrm{Kg}$ & $1 \bullet----5$ & Atacadistas \\
\hline sassafrás l & Lenho & Forno - Fechado & $\mathrm{S} / \mathrm{F}$ & Saquinhos de $30 \mathrm{~g}$ & $>20$ & Laboratórios \\
\hline sassafrás 1 & Raiz & Forno - Fechado & $>10 / 1$ & Saquinhos de $30 \mathrm{~g}$ & $>20$ & Laboratórios \\
\hline sene & Folha & Forno - Aberto & $\mathrm{S} / \mathrm{F}$ & A granel em sacos de $60 \mathrm{Kg}$ & $\mathrm{S} / \mathrm{F}$ & Atacadistas \\
\hline sene & Folha & Forno - Fechado & $>10 / 1$ & A granel em sacos de $60 \mathrm{Kg}$ & $\mathrm{S} / \mathrm{F}$ & Laboratórios \\
\hline sene & Folha & Forno - Fechado & $2 / 1 \bullet-\cdots--4 / 1$ & A granel em sacos de $60 \mathrm{Kg}$ & $\mathrm{S} / \mathrm{F}$ & Laboratórios \\
\hline sene & Outros & Forno - Fechado & $>10 / 1$ & Saquinhos de $30 \mathrm{~g}$ & $>20$ & $\begin{array}{l}\text { Lojas de produtos } \\
\text { naturais }\end{array}$ \\
\hline sene & Ramo & Forno - Aberto & $>10 / 1$ & $\mathrm{~S} / \mathrm{F}$ & $\mathrm{S} / \mathrm{F}$ & Atacadistas \\
\hline sene & Ramo & Forno - Fechado & & outros & $>20$ & Laboratórios \\
\hline sene & Ramo & Forno - Fechado & & Saquinhos de $30 \mathrm{~g}$ & $>20$ & Laboratórios \\
\hline
\end{tabular}

